\title{
Trehalose amide glycolipids as Mincle ligands: towards new vaccine adjuvants
}

\author{
By
}

Amy Therese Lynch

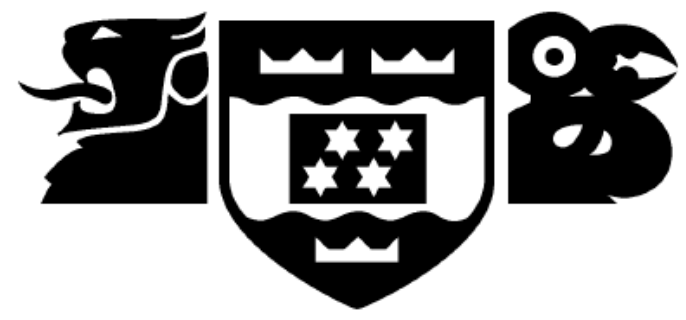

A thesis submitted to the Victoria University of Wellington in fulfilment of the requirements of a Master of Science (Chemistry)

Victoria University of Wellington

2018 


\section{Abstract}

The development of new vaccines to respond to infectious diseases requires new vaccine adjuvants, which improve vaccine efficacy and shape the immune response. Trehalose glycolipids, consisting of $\alpha, \alpha^{\prime}$-trehalose esterified at the 6- and 6'- positions with lipids, exhibit adjuvant activity by binding and activating Macrophage inducible C-type lectin (Mincle). However, the adjuvant activity of trehalose glycolipids could potentially be improved by substituting the ester linkages for more physiologically stable amide bonds. This thesis presents a short protecting group free route to trehalose amide glycolipids, thus allowing for the synthesis of the straight chain glycolipid amides 1a-e in four steps and in excellent (53-61\%) overall yields (Figure 1). Amide glycolipids 1a-e were demonstrated to be Mincle agonists with comparable activity to their ester counterparts, as determined using a green fluorescent protein (GFP) reporter cell line assay. A second generation of trehalose amide glycolipids, the lipidated brartemicin amide analogues 2a-c, were subsequently synthesised (Figure 1). This report is the first example of trehalose amide glycolipids acting as Mincle agonists, and further studies into the potential of the amides as vaccine adjuvants will be undertaken in due course.

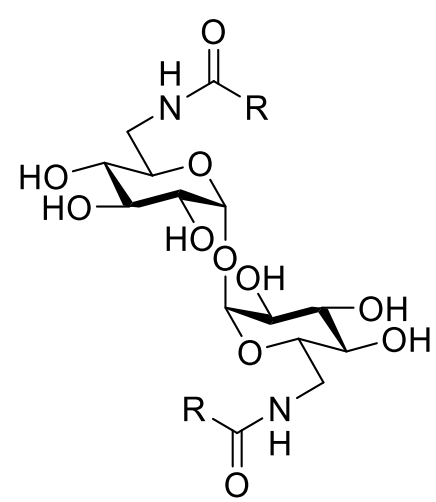

$$
\begin{aligned}
& \mathrm{R}=\mathrm{s}^{\mathrm{s}} \mathrm{Y} T_{n} \\
& \text { a } n=2 ; \mathbf{b} n=16 ; \mathbf{c} n=20 \\
& \text { d R }={ }^{s}+\mathrm{r}_{7}=\mathrm{Y}_{7} \\
& \text { e } \mathrm{R}={ }^{\mathrm{s}}+\mathrm{C}_{7}=\mathrm{Y}_{4}
\end{aligned}
$$

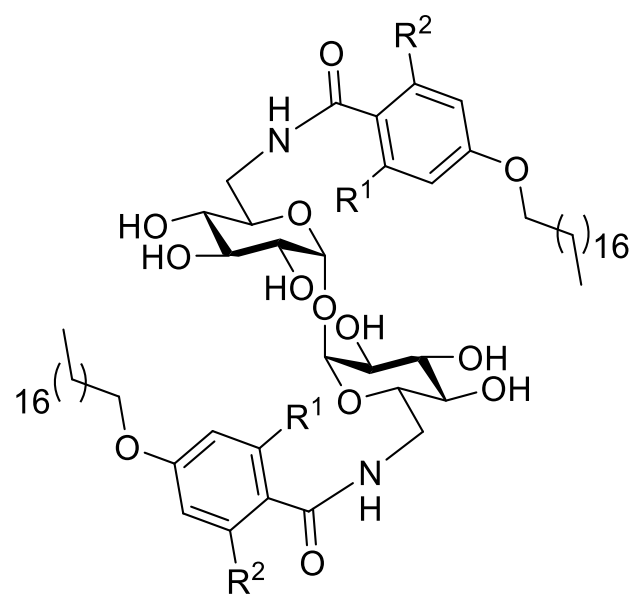

2a $\mathrm{R}^{1}=\mathrm{R}^{2}=\mathrm{H}$

2b $\mathrm{R}^{1}=\mathrm{OH} \mathrm{R}^{2}=\mathrm{H}$

$2 c \mathrm{R}^{1}=\mathrm{OH} \mathrm{R}^{2}=\mathrm{Me}$

Figure 1. Straight chain trehalose amide glycolipids 1a-e and lipidated brartemicin amide analogues 2a-c 


\section{Acknowledgements}

The period over which I have produced this thesis has been a time of much learning and growth. I am truly grateful to everyone who has supported and encouraged.

To my supervisors, Assoc. Prof. Bridget Stocker and Assoc. Prof. Mattie Timmer, thank you for welcoming me into your research group in the final year of my undergraduate degree. Your patience and encouragement while I developed my research skills and my confidence has been invaluable. Thank you for pushing me when you knew that I was capable of a bit more, even though I might not have realised it at the time.

To past and present members of the immunoglycomics research group, thank you for all your help and for making the lab an enjoyable place to work. You have all helped my work by discussing my research challenges; helping me learn new techniques and operating lab equipment; joking and singing together in the lab; and just unwinding together over a cup of tea. I would especially like to thank Amy Foster for being my mentor. From you I have learnt many of my skills for handling glycolipids and you have been a wealth of advice throughout my studies.

I would like to thank the Victoria Masters by Thesis Fees (Guaranteed) Scholarship for financial support, Professor Sho Yamasaki (Osaka Univesity, Japan) for the gift of the NFATGFP reporter cell lines, and Amy Foster for carrying out biological evaluation.

Finally, I would like to thank my family for their support and encouragement. You have been a source of love and kindness, even when I was stressed about chromatography and spectroscopy. To my brother Matthew, for your tech support and for "complimenting" me while simultaneously reminding me to be a bit less serious. For my sister Colleen, for sending me cute animal stress-relievers and your excellent grammar skills. To my father, Richard, for always reminding me how good I really am. To my mother, Andrea, you were my first science teacher and have been unconditionally supportive in so many ways, thank you. 


\section{List of Abbreviations}

\begin{tabular}{|c|c|}
\hline APC & Antigen presenting cell \\
\hline BCG & Bacillus Calmette-Guèrin \\
\hline BMM & Bone marrow derived macrophage \\
\hline BMDC & Bone marrow derived dendritic cell \\
\hline BSA & $\mathrm{N}, \mathrm{O}$-bis-trimethylsilylacetamide \\
\hline COSY & Correlation spectroscopy \\
\hline CRAC & Cholesterol recognition amino acid consensus \\
\hline CRD & Carbohydrate recognition domain \\
\hline CTL & C-type lectin \\
\hline DC & Dendritic cell \\
\hline DDA & Dimethyldioctadecylammonium bromide \\
\hline DIPEA & $N, N$-Diisopropylethylamine \\
\hline DMAP & 4-Dimethylaminopyridine \\
\hline DMF & Dimethylformamide \\
\hline EDCI & $N$-Ethyl- $N$ '-(3-dimethylaminopropyl)carbodiimide \\
\hline EVD & Ebola virus disease \\
\hline ELISA & Enzyme-linked immunosorbent assay \\
\hline GFP & Green-fluorescent protein \\
\hline HBTU & 2-(1H-benzotriazole-1-yl)-1,1,3,3-tetramethyluronium hexafluorophosphate \\
\hline HOBT & 1-Hydroxylbenzotriazole \\
\hline HIV & Human immunodeficiency virus \\
\hline HMBC & Heteronuclear Multiple Bond Correlation \\
\hline HPLC & High performance liquid chromatography \\
\hline
\end{tabular}




\begin{tabular}{|c|c|}
\hline HPV & Human papillomavirus \\
\hline HRMS & High resolution mass spectrometry \\
\hline HSQC & Heteronuclear single quantum correlation \\
\hline IFN- $\gamma$ & Interferon- $\gamma$ \\
\hline $\mathrm{IL}-1 \beta$ & Interleukin-1 $\beta$ \\
\hline IL-6 & Interleukin-6 \\
\hline IL-10 & Interleukin-10 \\
\hline IR & Infrared \\
\hline ITAM & Immunoreceptor tyrosine based activation motif \\
\hline LPS & Lipopolysaccharide \\
\hline MCL & Macrophage C-type lectin \\
\hline $\mathrm{MHC}$ & Major histocompatibility complex \\
\hline Mincle & Macrophage inducible C-type lectin \\
\hline MPLA & Monophosphoryl lipid A \\
\hline NFAT & Nuclear factor of activated T-cells \\
\hline NMR & Nuclear Magnetic Resonance \\
\hline PAMP & Pathogen associated molecular pattern \\
\hline PBMC & Peripheral blood mononuclear cell \\
\hline PRR & Pathogen recognition receptor \\
\hline TBAI & Tetrabutylammonium iodide \\
\hline TCR & T-cell receptor \\
\hline TDB & Trehalose dibehenate \\
\hline TDCM & Trehalose dicornymycolate \\
\hline TDM & Trehalose dimycolate \\
\hline
\end{tabular}


TGL Trehalose glycolipid

Th-1 T helper type 1

Th-2 T helper type 2

Th-17 T helper type 17

TLC Thin layer chromatography

TLR Toll-like receptor

TMS Trimethylsilyl

TNF- $\alpha \quad$ Tumour necrosis factor- $\alpha$

SAR Structure activity relationship

WHO World Health Organisation 


\section{Contents}

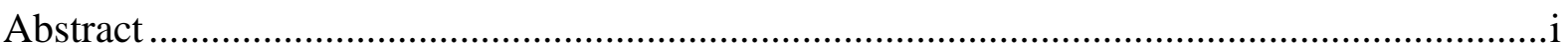

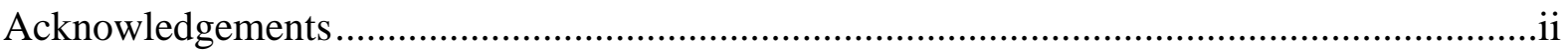

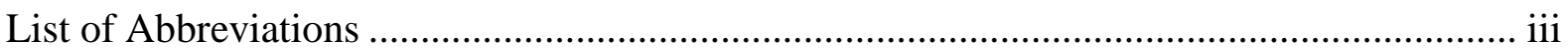

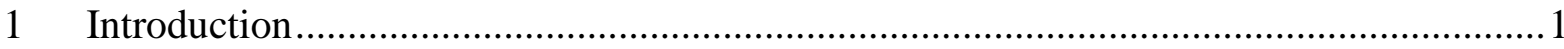

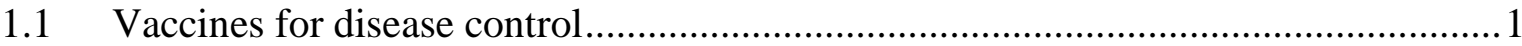

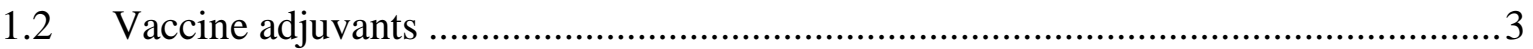

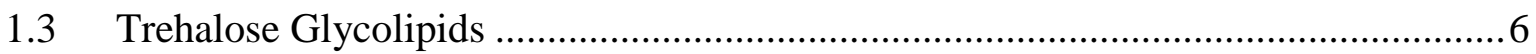

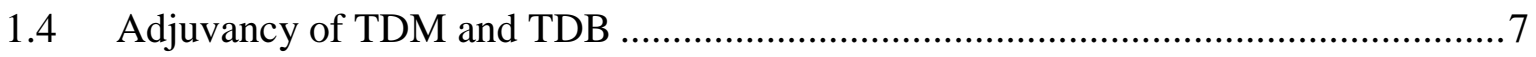

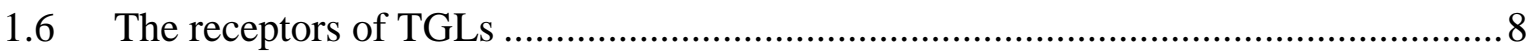

1.6.1 Macrophage inducible C-type lectin (Mincle) ..............................................

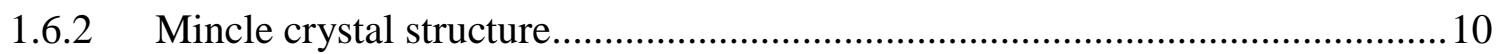

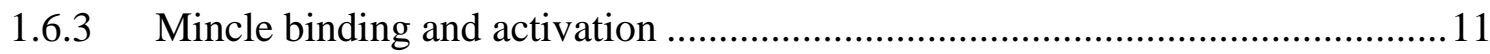

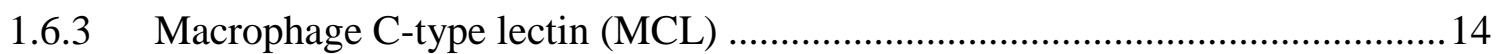

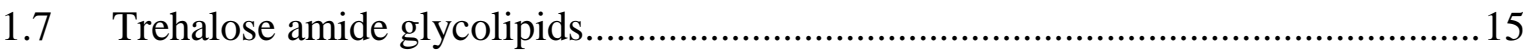

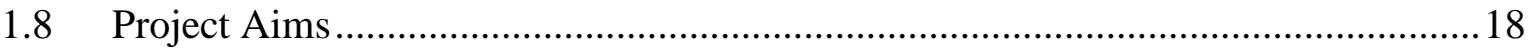

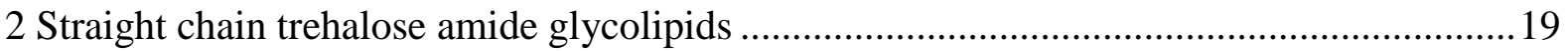

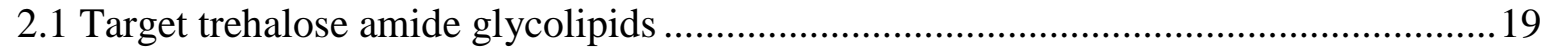

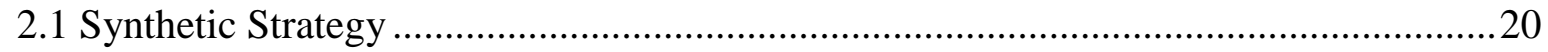

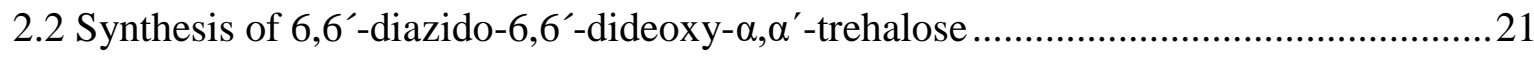

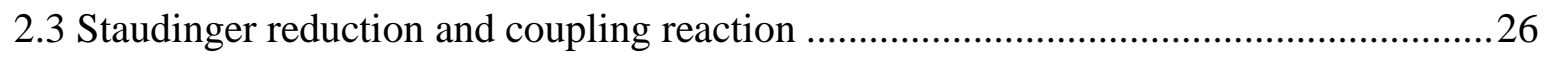

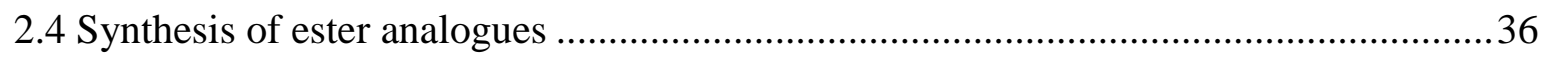

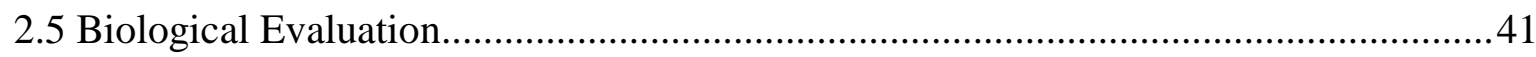

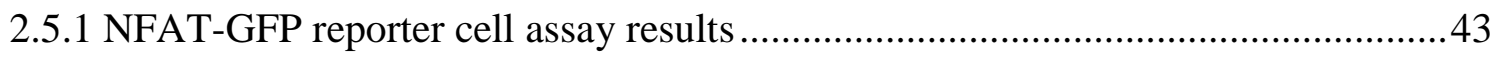

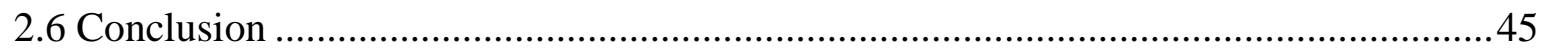

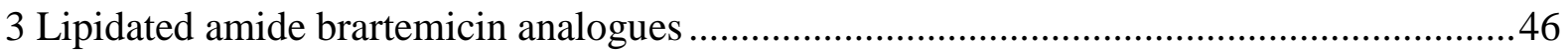

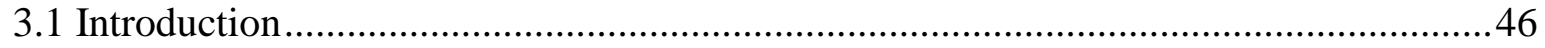




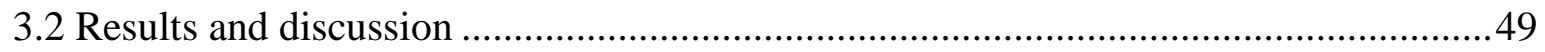

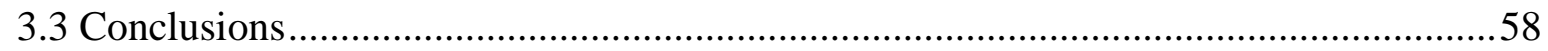

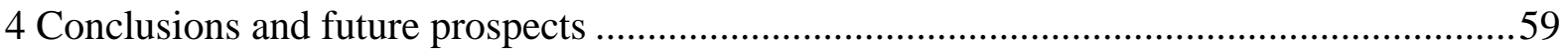

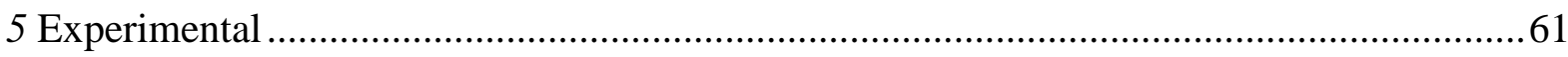

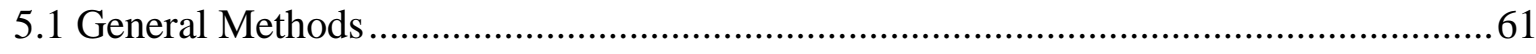

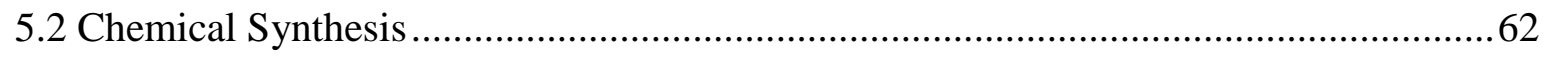

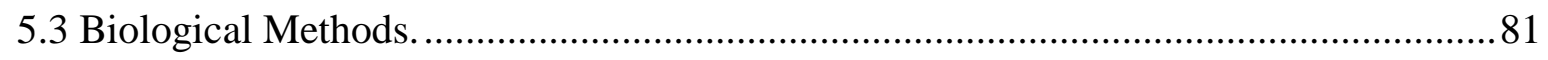

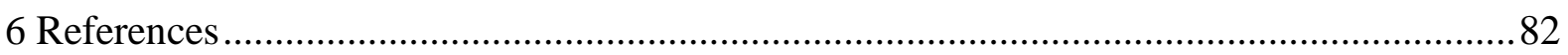

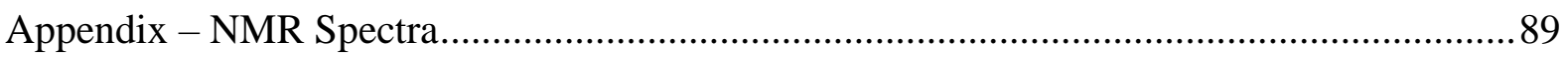




\section{Introduction}

\subsection{Vaccines for disease control}

New solutions to counter the global burden of infectious diseases are required. The second most common causes of deaths world-wide are infectious and parasitic diseases. ${ }^{1}$ Many fatalities are caused by diseases such as malaria, tuberculosis and human immunodeficiency virus (HIV), which have ongoing human infection and lack highly effective cures. ${ }^{1}$ Emerging diseases, which are new infections or previously reported infections with a sudden escalation in incidence or geographic range, pose an additional threat. ${ }^{2-3}$ Incidences of emerging infectious diseases are increasing, ${ }^{3}$ the cause postulated to be the evolution of microbes to new niches created by changing environments and human behaviours. ${ }^{2}$ Consequently, infectious diseases are, and will continue to be, challenges for humankind, to which solutions must be found.

Prior responses to the challenge of infectious diseases testify to the power of vaccination for disease control. Vaccination has effectively controlled or eradicated many infectious diseases in the past, notably the discovery that inoculation with cow pox produced small pox immunity, ultimately leading to the eradication of small pox in the twentieth century. ${ }^{4-5}$ Vaccination for the childhood diseases measles, mumps and rubella further illustrates the capacity of vaccines to reduce disability and mortality caused by infectious diseases. ${ }^{6-8}$ Moreover, the resultant public health benefits have many flow on effects, such as economic benefits through reduced health care costs. ${ }^{9}$ Accordingly, vaccination has been recognised by the World Health Organisation (WHO) as a core component to the human right to health, and the WHO aims to develop global equitable vaccine access. ${ }^{10}$

Vaccine development is also an important part of the response to emerging infectious diseases. ${ }^{2} \mathrm{~A}$ recent example of this is the rapid development of a vaccine during the 2013-2016 Ebola virus outbreak in West Africa. This outbreak of Ebola virus disease (EVD) is the largest known, with infections in urban settings greatly aiding transmission of the disease. ${ }^{11}$ Accordingly, the development of a vaccine against Ebola virus was prioritised and occurred with unprecedented speed and scale. ${ }^{12}$ 
Understanding how successful vaccines confer protection against a specific pathogen will assist in developing the next generation of vaccines. The aim of vaccination is to produce immunological memory, which will lead to a swift immune response upon infection. ${ }^{13}$ Vaccines establish immunological memory by mimicking an infection by a disease causing pathogen, without causing the severe symptoms of the disease. The first vaccines, live attenuated vaccines, mimicked natural infections by containing pathogens with greatly reduced virulence. ${ }^{4-5}$ Attenuated strains were sometimes identified in nature, for example cow pox used for small pox inoculation, ${ }^{5}$ but later manufactured by prolonged culturing of pathogens in appropriate media, or more recently by recombinant DNA technologies. ${ }^{14-16}$ Attenuated vaccines have subsequently led to the development of killed vaccines and then sub-unit vaccines, which are vaccines which only contain a defined unit of a pathogen. ${ }^{17-18}$

Robust immunological memory following vaccination requires the generation of pathogen specific adaptive immune cells. Immunity is often measured by the presence of persistent circulating blood antibodies. Antibodies are proteins that bind specific biomolecules (antigens) of the pathogen, neutralising the pathogen and marking it for destruction. ${ }^{18-21}$ B-cells, which are cells of the adaptive immune system which confer pathogen specific immunological memory, produce antibodies. ${ }^{22}$ However, in addition to B-cells, other adaptive cells, namely T-cell populations, must also be generated by effective vaccines. When naïve T-cells are stimulated, they expand to form populations of $\mathrm{CD}^{+} \mathrm{T}$-cells, also known as helper T-cells, which activate other cells such as B-cells, and $\mathrm{CD} 8^{+} \mathrm{T}$ cells, also called cytotoxic T-cells, which kill infected host cells. ${ }^{23}$ The importance of vaccines producing both long-lived T-cells and B-cells is demonstrated by the longevity of B-cells, $\mathrm{CD}^{+}-$and $\mathrm{CD} 8^{+}$-T-cells produced from the smallpox vaccine, which provides especially high and lasting immunity. ${ }^{19,24}$ In addition, the type of immune response, including whether it is dominated by B-cells or T-cells, and which T-cell subtypes are present, is also important. ${ }^{25}$ For example, T helper type 17 (Th-17) cells are important for vaccine-induced responses against bacteria such as Mycobacterium tuberculosis and Streptococcus pneumoniae. ${ }^{26}$ Robust immunological memory following vaccination therefore depends on vaccines stimulating the production of the appropriate profile of long-lived adaptive immune cells.

A current challenge in immunisation is developing vaccines which stimulate the production of a suitable adaptive immune cell profile. In general, attenuated vaccines are highly efficacious at producing immunological memory. ${ }^{13}$ However, there is growing interest in developing sub-unit vaccines. This is due to subunit vaccines being considered safer and having fewer side effects, as the components of a sub-unit vaccine are more firmly defined than their attenuated and killed vaccine 
counterparts. ${ }^{17}$ However, subunit vaccines often lack efficacy due to their inability to appropriately prime and shape the adaptive immune response. ${ }^{17,27}$

\subsection{Vaccine adjuvants}

Vaccines, particularly subunit vaccines, can lack efficacy if they fail to appropriately stimulate cells of the innate immune system. The innate immune system is the branch of the immune system that swiftly and non-specifically responds to infection. ${ }^{28}$ While the innate immune system does not include memory cells, proper activation of the innate immune system is required to activate the adaptive immune system. ${ }^{17,27}$ Antigen presenting cells (APCs), such as dendritic cells (DCs) and macrophages, provide an important link between the innate and adaptive immune systems. APCs are attracted to infection sites, where they internalise pathogens (or pathogen fragments) and display the pathogenic antigens on their cell surface via major histocompatibility complexes (MHCs). This allows pathogen specific naïve T-cells in the lymph node to recognise the antigens via the T-cell receptor (TCR) (Figure 2). ${ }^{29-30}$ Simultaneously, pathogen associated molecular patterns (PAMPs) on the pathogen bind to the pathogen recognition receptors (PRRs) of the APCs, stimulating the release of cytokines. The set of cytokines produced determines which subtype the naïve T-cell that recognises the antigen differentiates into, thus shaping the type of adaptive immune response that follows. ${ }^{27,30}$ Live attenuated vaccines have been found to stimulate APCs, for example the yellow fever vaccine stimulates DCs via a class of PRRs called toll-like receptors (TLRs), resulting in a T helper type 1 (Th-1)/T helper type 2 (Th-2) immune response. ${ }^{31}$ However, sub-unit vaccines often lack the necessary constituents to appropriately stimulate APCs and initiate a robust adaptive immune response. ${ }^{17,27}$ Therefore, to improve vaccine efficacy the addition of components to appropriately stimulate APCs of the innate immune system is required. 


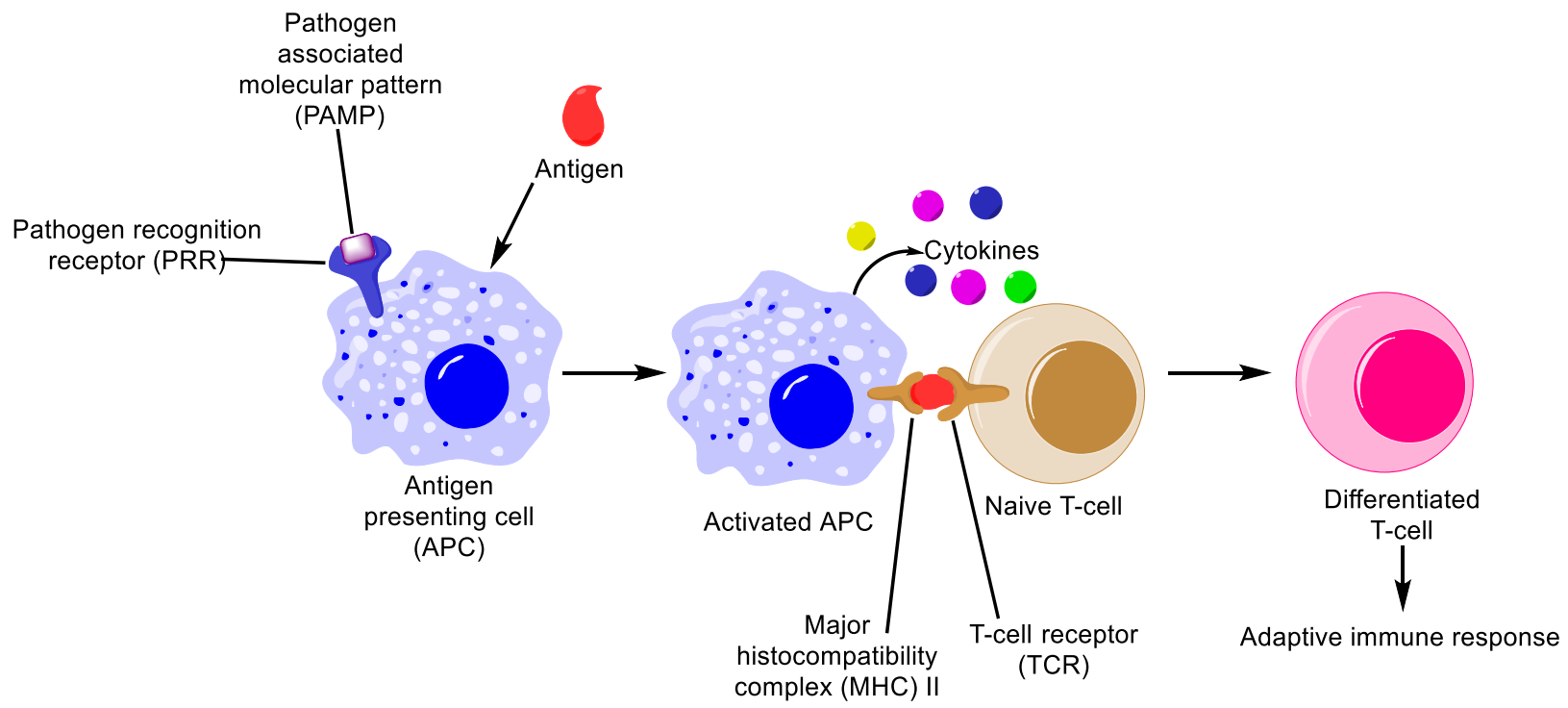

Figure 2. Generation of an adaptive immune response: The PAMP binds to the PRR on the APC leading to the release of cytokines. Concurrently, antigens taken up by the APC are presented by MHC II on the cell surface. The T-cell with the correct TCR recognises and binds the antigen-MHC II complex. The cytokine profile produced by the APC determines how the naïve T-cell differentiates, thus shaping the adaptive immune response.

Adjuvants, such as alum salts and water-oil emulsions, are added to vaccines to improve the immune response by increasing the magnitude or altering the type of immune response. ${ }^{27}$ Although the mechanism of action of some types of adjuvants, such as alum, requires further investigation, ${ }^{32}$ it has been demonstrated that certain classes of adjuvant can exert their effect by stimulating innate immune system cells via PRRs, such as TLRs and C-type lectins (CTLs). ${ }^{25,} 27$ This has led to the development of molecular adjuvants, including bacterial glycolipids. A notable example of a bacterial glycolipid adjuvant is monophosphoryl lipid A (MPLA, 3, Figure 3), which is derived from lipopolysaccharide (LPS) isolated from the cell wall of Gram-negative bacteria. ${ }^{33-34}$ Liposomes containing MPLA as an adjuvant have been used in vaccines for malaria, HIV, and prostate cancer, which all have reached human clinical trials. ${ }^{35}$ Currently, MPLA is used with alum salts as the adjuvant AS04 that is used in the licensed vaccine for human papillomavirus (HPV), Cervarix ${ }^{\circledR}{ }^{36}$ 


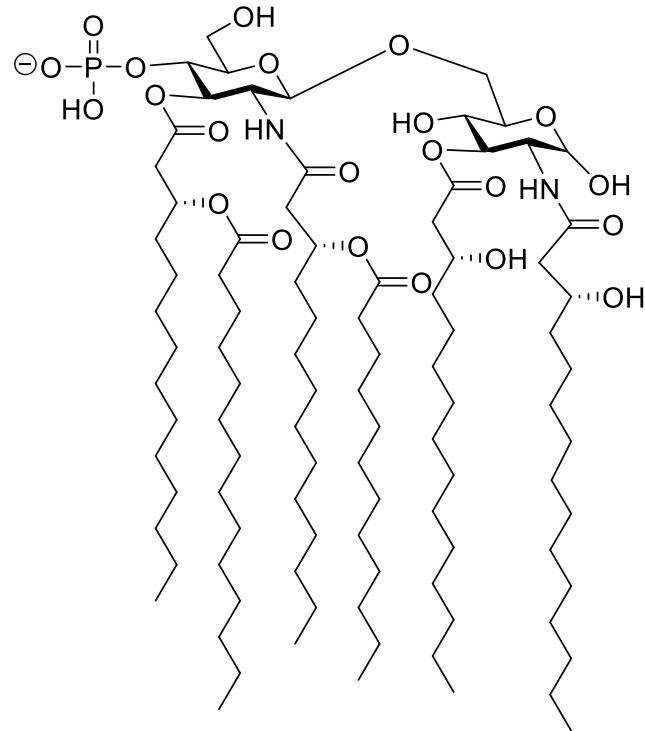

Escherichia coli Monophosphoryl Lipid A (MPLA, 3)

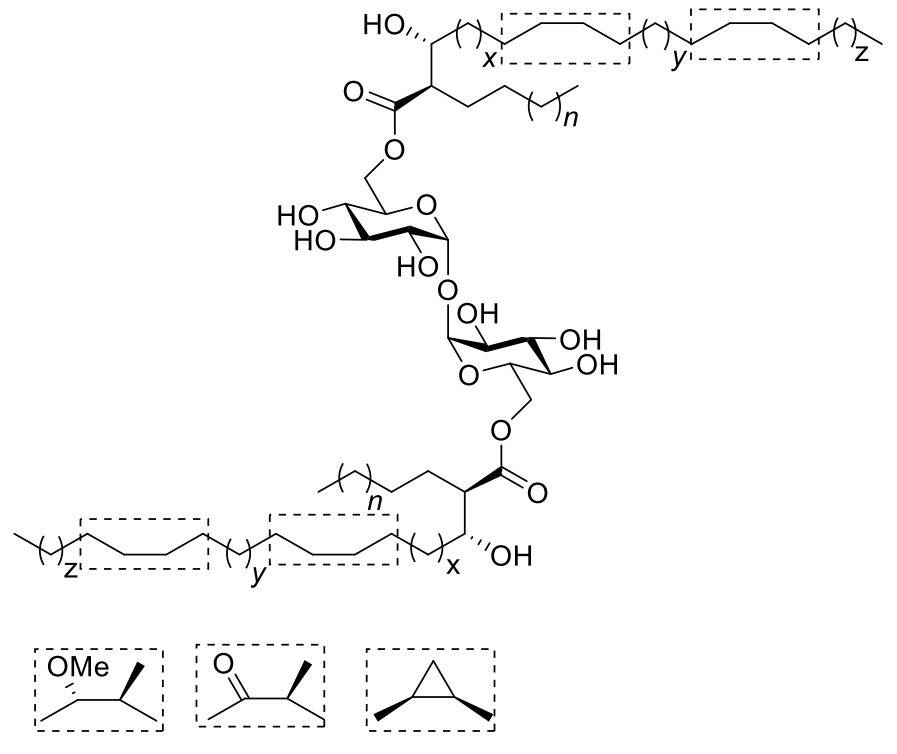

Trehalose dimycolate (TDM, 4)

e.g. $n=19, x=11, y=14, z=19$

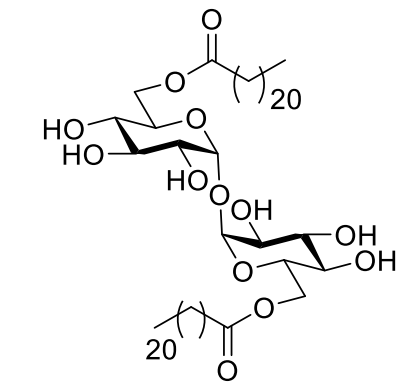

Trehalose dibehenate (TDB, 5)

Figure 3. Bacterial glycolipids with adjuvancy

As previously discussed, there are currently still many infectious diseases for which there are no effective vaccines. Adjuvant development is a vital aspect of producing new vaccines, therefore the identification and optimisation of molecules with adjuvancy is important for vaccine development. One class of molecules which show promise as adjuvants are the trehalose glycolipids (TGLs). ${ }^{37}$ Like MPLA, TGLs are also bacterial glycolipid PAMPs. Noteworthy TGLs include trehalose dimycolate (TDM, 4), found in the cell wall of Mycobacteria, and its synthetic analogue trehalose dibehenate (TDB, 5) (Figure 3). ${ }^{38-40}$ TDB has been formulated with the cationic surfactant dimethyldioctadecylammonium bromide (DDA) as liposomes to form the adjuvant CAF01, which has shown promise as an adjuvant in vaccines against tuberculosis and HIV. ${ }^{41}$ However, vaccines containing CAF01 as an adjuvant have not shown sufficient efficacy in human trials for HIV. ${ }^{42}$ Thus, further optimisation of TGL adjuvants could benefit vaccine development. 


\subsection{Trehalose Glycolipids}

As previously stated, TGLs are bacterial glycolipids which have been isolated from a range of bacterial species. The first TGL isolated was TDM (also known as "cord factor") from M. tuberculosis. ${ }^{40,43}$ Subsequently, TGLs have been isolated from the cell walls of Corynebacteria, Rhodococcus and Nocardia species; from the dauer larvae of the nematode Caenorhabditis elegans; and prepared synthetically, such as TDB and analogues. ${ }^{37,44-45}$

TGLs, whether naturally occurring or synthetic, are diverse in structure. A major structural class is the 6,6'-trehalose diesters which includes TDM (4) and TDB (5) (Figure 3); trehalose dicorynomycolates (TDCMs, 6), which were isolated from Corynebacteria $;{ }^{46-47}$ and maradolipids (7), which were isolated from C. elegans (Figure 4). ${ }^{37,44}$ The 6,6'-trehalose diesters all contain trehalose, an $\alpha, \alpha^{\prime}$-linked disaccharide of glucose, but they have unique lipids esterified to the 6- and 6'-hydroxyls of trehalose. TDM is a diester of mycolic acid, which is a $\beta$-hydroxy fatty acid with two branches - an unfunctionalised $\alpha$-branch, and a meromycolate branch which is functionalised with groups such as cyclopropanes, methoxides, ketones and epoxides. ${ }^{37,48}$ The dicorynomycolates are trehalose diesters of the related $\beta$-hydroxy acids, the corynomycolic acids, which lack a functionalised branch, so each branch varies only in length. ${ }^{37}$ Maradolipids (7), can either be symmetrical or asymmetrical, whereby the major components of maradolipids contain an iso-branched lipid and an unsaturated lipid. ${ }^{44}$ Diesters of simple straight chain fatty acids have also been identified from C. elegans, ${ }^{44}$ and synthetically prepared, with TDB, the 22 carbon derivative, being the most widely synthesised and studied due to its use as an adjuvant. ${ }^{37,41,49}$ Differences in TGL structure, even minor variations, such as lipid length or functional group pattern, can affect the immune response. ${ }^{50}$ 

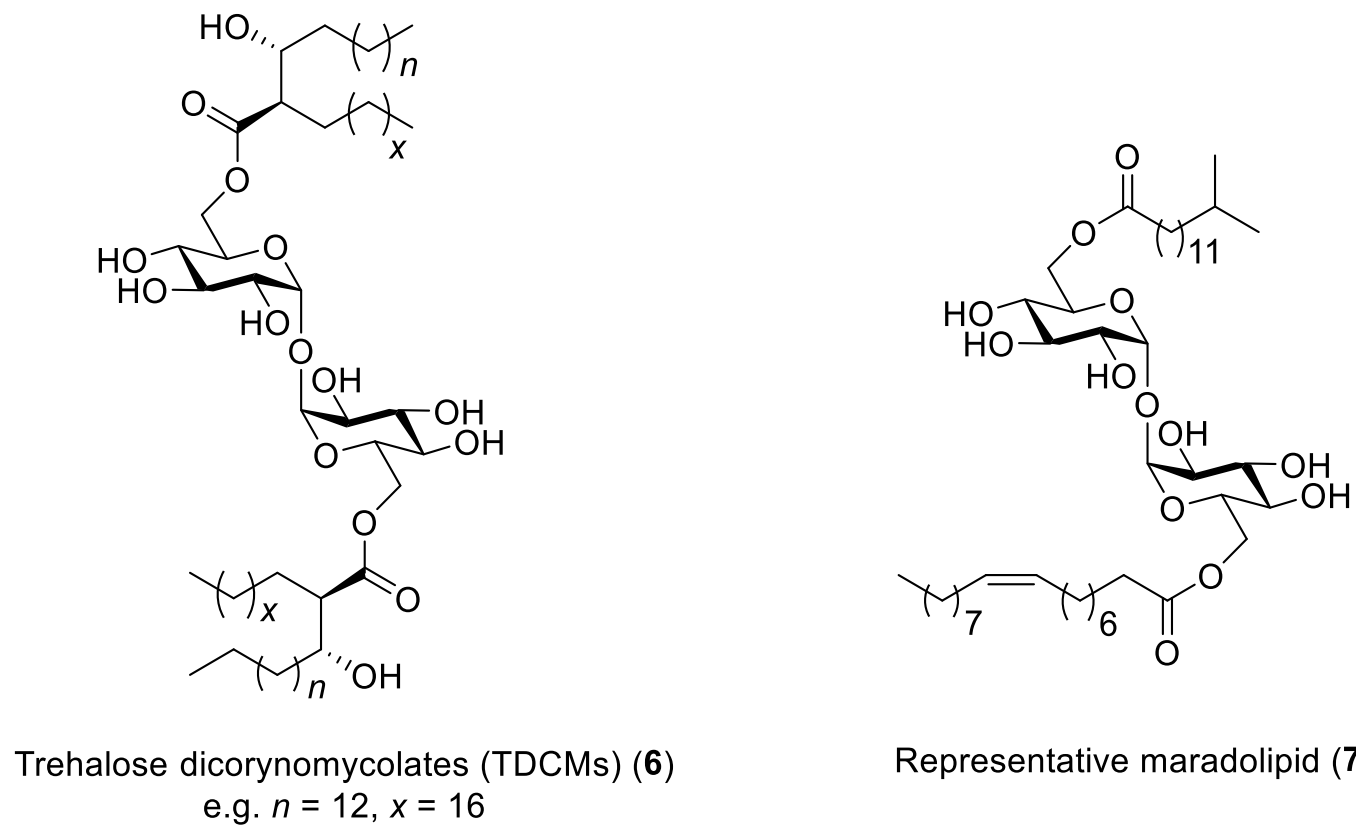

Representative maradolipid (7)

Figure 4. Trehalose dicorynomycolates and maradolipid

\subsection{Adjuvancy of TDM and TDB}

TGLs have been known to be immunostimulatory compounds for some time, with seminal work in this area focusing on the role of TDM in M. tuberculosis infection. ${ }^{43,51-52}$ The immunostimulatory activity is also utilised for adjuvants. For example, the efficacy of Freund's adjuvant, which is widely used in research and contains heat killed M. tuberculosis, has been attributed to TDM. ${ }^{27}$ Similarly, the currently used tuberculosis vaccine, Bacillus Calmette-Guérin (BCG) contains Mycobacterium bovis and the lipid responsible for producing the most potent pro-inflammatory response in the vaccine is TDM. ${ }^{53}$ In view of this, TDM and other lipids extracted from $M$. bovis have been formulated with the cationic surfactant DDA in liposomes and used as a vaccine adjuvant, which has shown promise in animal studies. ${ }^{38}$ However, TDM adjuvancy is offset by formulation dependant toxicity - administering TDM to mice as an oil emulsion is toxic, ${ }^{40,54}$ while TDM administered to mice as micelles is nontoxic. ${ }^{55}$ An additional shortcoming is that extracted TDM contains a complex mixture of lipids, which does not align with the goal of developing defined vaccine adjuvants and subunit vaccines.

With a view to developing more defined TGL vaccine adjuvants, the adjuvancy of a synthetic analogue of TDM, TDB, has been widely investigated. A particularly pertinent TDB adjuvant involves the formulation of TDB in DDA liposomes, which is known as the CAF01 adjuvant system. ${ }^{39,41}$ CAF01 has been shown to have adjuvancy in vaccines for tuberculosis, malaria and chlamydia in mice. ${ }^{41}$ The 
efficacy of CAF01 has been attributed to the vaccine initiating a Th1 and Th17 immune response, ${ }^{56}$ with the Th17 response being particularly important for protection against intracellular pathogens. ${ }^{26,}$ 57-58 The T-cell subtype produced, such as Th1 or Th17, depends on the cytokine profile elicited by the APCs which in turn depends on the PRR that the adjuvant activates and the exact molecular structure of the adjuvant. ${ }^{30,59}$

\subsection{The receptors of TGLs}

\subsubsection{Macrophage inducible C-type lectin (Mincle)}

Although the immunostimulatory activity of TGLs, and in particular TDM, has been known for some time, it was only in 2009 that the first receptor for TDM, the macrophage inducible C-type lectin (Mincle, Clec4d, ClecSf8), was identified ${ }^{60}$ In experiments to identify the receptor for TDM, a reporter cell line that expressed green-fluorescent protein (GFP) when a ligand signalled through Mincle was utilised. ${ }^{60}$ Here, Mycobacteria species and TDM, fractionated from the lipid extract of Mycobacteria by high performance liquid chromatography (HPLC), caused GFP expression. ${ }^{60}$ This evidence strongly suggested that TDM signalled through Mincle, with the hypothesis being corroborated by genetic knockout studies. TDM and TDB did not cause cytokine production in BMMs that did not express Mincle (Mincle ${ }^{-/-}$BMMs). ${ }^{60-61}$ Furthermore, Mincle $^{-/-}$mice did not generate a robust Th17 response upon vaccination with a DDA and TDB adjuvant system. ${ }^{61}$

Several other studies have been conducted to understand how the binding and activation of Mincle initiates an intracellular signalling pathway and ultimately cytokine production. Upon Mincle activation the immunoreceptor tyrosine-based activation motif (ITAM) of FcR $\gamma$ binds to Mincle at a positive arginine residue in the intracellular domain. ${ }^{62}$ The signalling pathway continues via the kinase Syk, a distinct pathway from TLRs which signals via the adaptor protein MyD88. ${ }^{63}$ Recruitment of Syk causes a Card9-MALT 1 -Bcl10 complex to assemble, in turn causing NFkB to translocate to the nucleus and initiate transcription of genes required for cytokine production (Figure 5). ${ }^{63-64}$ Thus, Mincle signalling plays a crucial role in the ability of TGLs to act as adjuvants. 


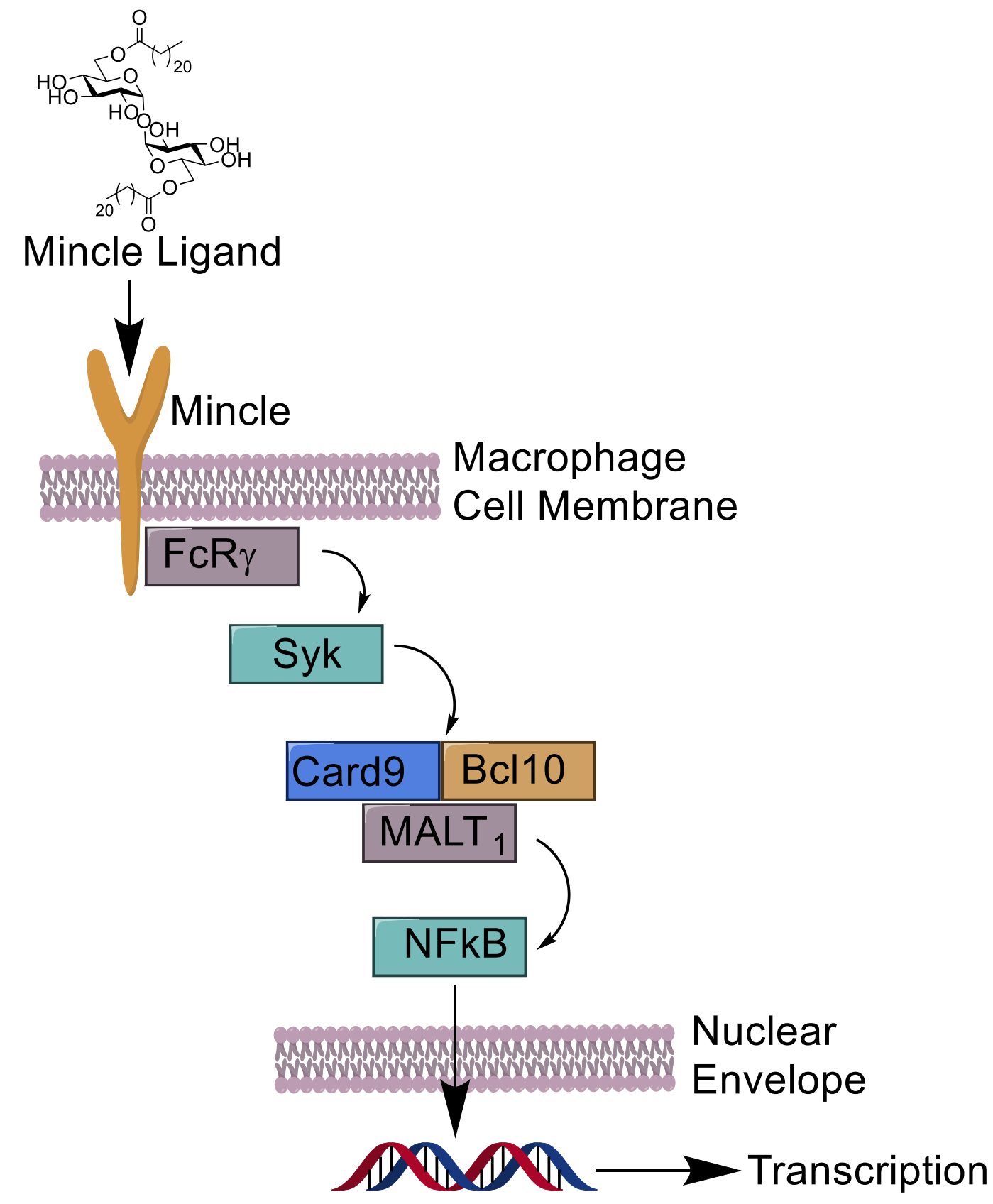

Figure 5. Mincle signalling pathway: Following binding of the Mincle ligand (e.g. TDB) to Mincle, $\mathrm{FcR} \gamma$ is recruited to Mincle initiating the signalling pathway. This results in the recruitment of the kinase Syk which causes the assembly of a Card9-MALT 1 -Bcl10 complex. Formation of the complex induces translocation of NFKB to the nucleus, ultimately leading to the transcription of genes required for cytokine production 


\subsubsection{Mincle crystal structure}

The crystal structures of both bovine and human Mincle have been obtained. ${ }^{65-66}$ In both crystal structures, similar regions important for TGL binding have been identified. One such feature is the carbohydrate recognition domain (CRD), which contains a $\mathrm{Ca}^{2+}$ ion and a glutamic acid-prolineasparagine (EPN) binding motif (Figure 6) ${ }^{65-66}$ In the bovine Mincle crystal structure, with trehalose in the active site, trehalose binds in the CRD with the 3- and 4-OH of one glucose sugar coordinating to the $\mathrm{Ca}^{2+}$ ion. ${ }^{66}$ Extending away from the CRD is a hydrophobic groove, where it is predicted that the lipid portion of TGLs bind. ${ }^{65-66}$ Indeed, a crystal structure of Mincle bound to monobutanoyl shows the acyl group being aligned with the start of the hydrophobic groove. ${ }^{67}$ Furthermore, while trehalose only modestly inhibits the binding of ${ }^{125}$ I-Man-BSA to Mincle (inhibition constant, $K_{I}$, of $2200 \pm 300$ $\mu \mathrm{M})$, trehalose dihexanoate has a significantly lower $K_{I}$ of $8.2 \pm 0.3 \mu \mathrm{M} .{ }^{67}$ Overall, this suggests that a ligand must interact with both the CRD and the hydrophobic groove of Mincle to enhance the binding affinity to the EPN CRD motif .

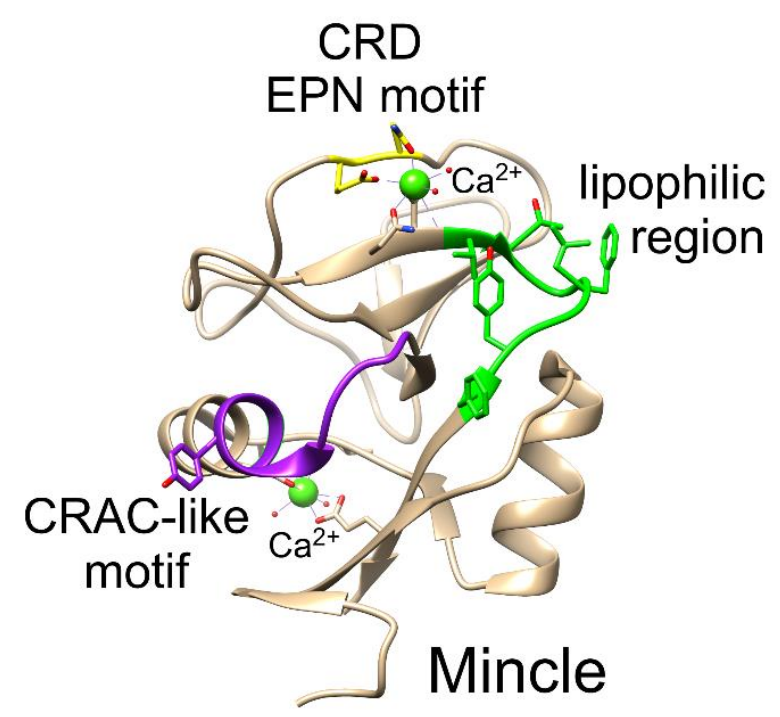

Figure 6. The crystal structure of human Mincle. The key regions identified for ligand regions are the CRD EPN motif (yellow) with a $\mathrm{Ca}^{2+}$ ion for binding trehalose and the lipophilic region (green) for binding lipids. A secondary binding site, the CRAC-like motif (purple) is also shown. Image originally published in Braganza et al. Front. Immunol. 2018, 8, 1940. Reproduced with permision of authors. 


\subsubsection{Mincle binding and activation}

While the crystal structures can assist with ligand design, Mincle, and by extension APC, activation must be confirmed by biological evaluation. Therefore, analysis of the structure of known Mincle ligands should be used to identify key structural features required for Mincle activation.

Current structure activity relationships (SARs) for TGLs corroborate the interpretations of the crystal structures. Neither purified mycolic acids or trehalose alone could activate Mincle, as determined using GFP reporter cell lines,$^{60}$ thereby supporting the notion that both the binding of the CRD domain and the hydrophobic groove appear to be essential for Mincle activation. Furthermore, trehalose 6,6'diesters of straight chain fatty acids must have $\geq 12$ carbons to activate macrophages to produce cytokines and chemokines, ${ }^{49,} 68-69$ demonstrating the importance of binding the hydrophobic groove. Lipid length also affects the biological profile, as illustrated by trehalose 6,6'-diesters with acyl carbon chains of $\mathrm{C} 12$ and $\mathrm{C} 14$ causing BMMs to produce the chemokine MIP-2, but not the cytokines interleukin-1 $\beta$ (IL-1 $\beta$ ) and interleukin (IL-10) which are produced upon stimulation with the C18 analogue. ${ }^{68}$ Monoesters of trehalose with long (C22 and C26) straight chain fatty acids have also been found to activate macrophages in a Mincle-dependent manner. ${ }^{70}$ Other studies have found monoesters to have reduced activity to their diester counterparts, ${ }^{69}$ however, the difference between the two studies may be due to experimental design. Nevertheless, synthetic trehalose monomycolates have been found to be Mincle ligands with adjuvancy in in vivo assays which is comparable to their diester counterparts. ${ }^{71}$ Overall, these results suggest that to activate Mincle, TGLs must contain at least one suitably long lipid to ensure effective binding of the hydrophobic groove identified in the crystal structures.

Mincle ligands other than TGLs have also been identified, and analysis of their structures can also contribute to ligand design. Malassezia species of pathogenic fungi have been found to activate Mincle in a CRD dependent manner, and this activity has been attributed to glycolipids 8 and 9 (Figure 7). ${ }^{72-}$ ${ }^{73}$ Glycolipids $\mathbf{8}$ and $\mathbf{9}$ both contain disaccharides; the disaccharide of $\mathbf{8}$ is linked to lipids via a glycerol moiety while the disaccharide of $\mathbf{9}$ is joined to glycosylated lipids by the unusual sugar L-mannitol. Glycerol monomycolate (10), found in Mycobacteria cell walls, and the synthetic analogue glycerol monobehenate (11) have been found to act as ligands for human but not murine Mincle. ${ }^{74}$ The difference in activity between the murine and human Mincle proteins has been attributed to amino acid residues 174-176 or 195-196, as mutation of these murine amino acids to the corresponding human counterparts resulted in some activation of the mutated murine Mincle by glycerol monomycolate. ${ }^{74}$ 
The intracellular metabolite $\beta$-glucosylceramide (12) has also been found to activate Mincle. ${ }^{75}$ Brartemicin (13), a natural product isolated from Nonomuraea species, ${ }^{76}$ has also been investigated as a Mincle ligand (Figure 7). Brartemicin exhibited greater affinity for Mincle binding than trehalose in assays measuring the inhibition of mannose-conjugated serum albumin binding to the CRD of bMincle (trehalose $K_{I}=1620 \pm 70 \mu \mathrm{M}$, brartemicin $K_{I}=5.5 \pm 0.9 \mu \mathrm{M}$ ). ${ }^{77}$ Computational modelling suggested that the aromatic rings may have favourable interactions with an arginine residue in the hydrophobic groove of Mincle. ${ }^{77}$ However, it should be noted that neither trehalose or brartemicin have been reported to activate Mincle to produce a functional immune response. Plate coated cholesterol (14a) or cholesterol crystals have also been found to activate human Mincle but not murine Mincle, although this is likely through a different binding site as mutation of the cholesterol recognition amino acid consensus (CRAC) like sequence abolished the observed activity (Figure 7). ${ }^{78}$ Similarly, cholesterol sulphate (14b) which may be released upon skin damage or allergic skin inflammation, has been found to be a Mincle agonist (Figure 7). ${ }^{79}$ 

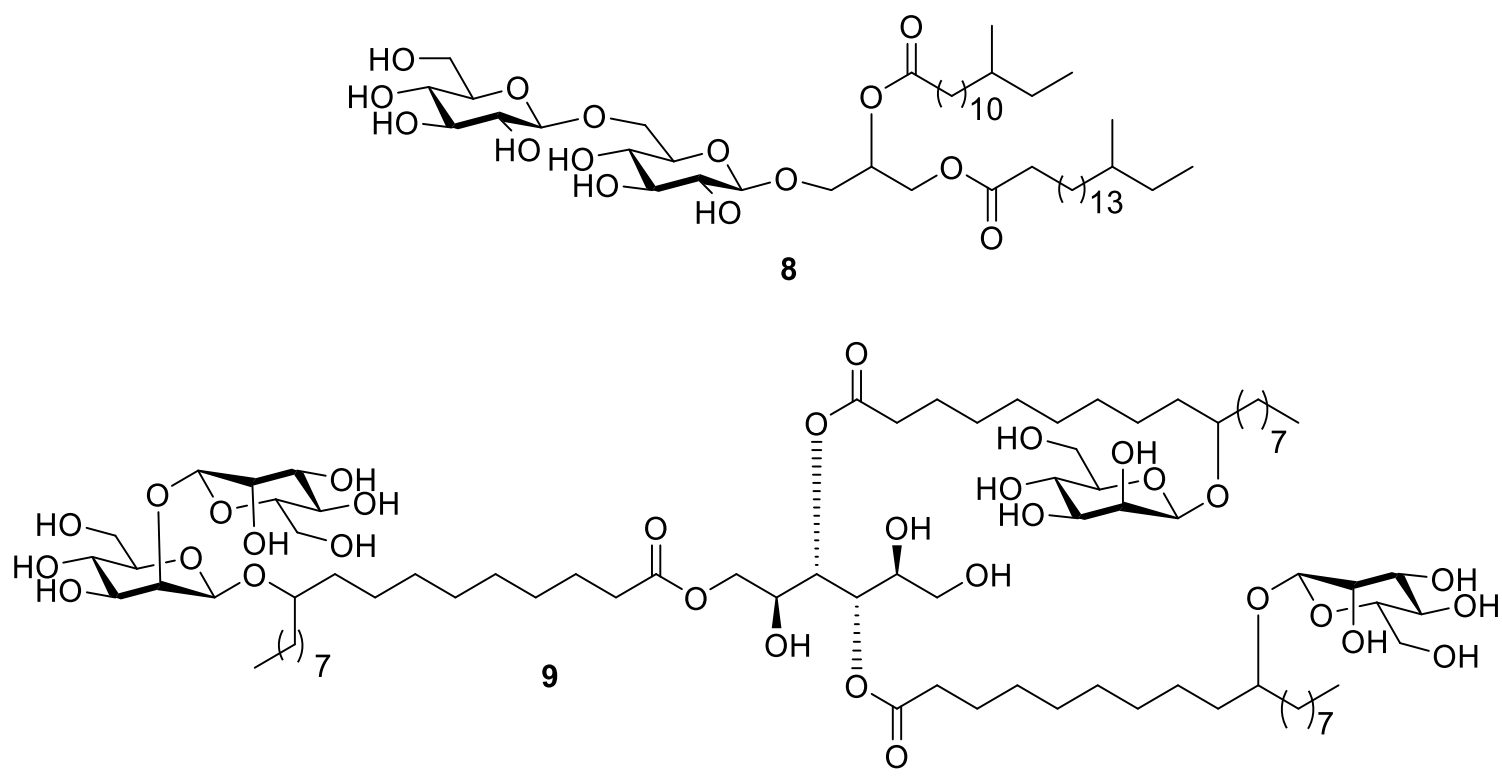

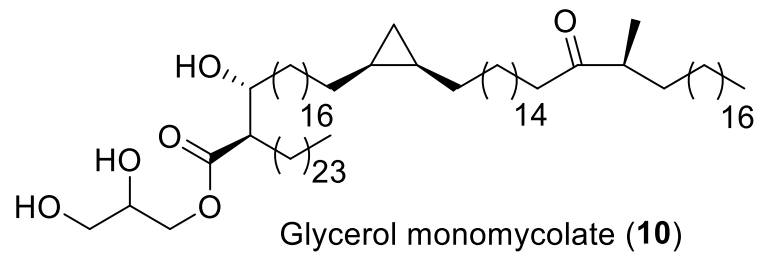<smiles>CC(C)CC(=O)OCC(O)CO</smiles>

Glycerol monobehenate (11)

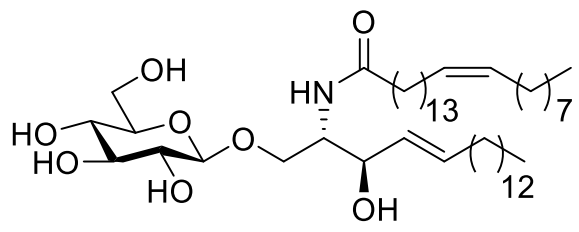

Representative $\beta$-glucosylceramide (12)

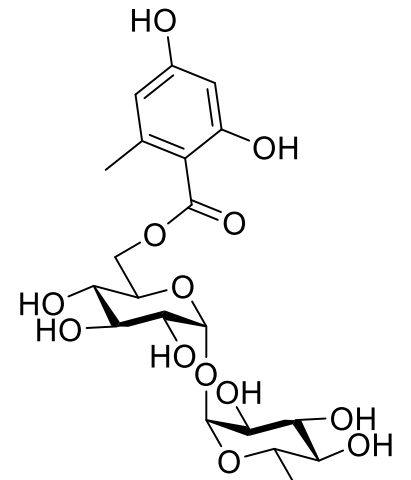<smiles>COC(=O)c1c(C)cc(O)cc1O</smiles>

Brartemicin (13)

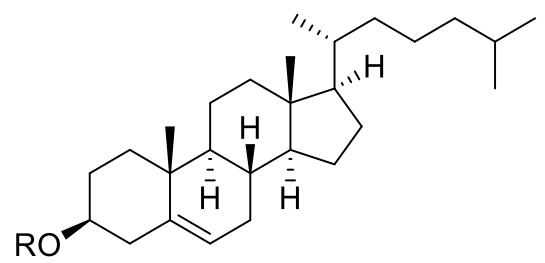

Cholesterol (14a) $\mathrm{R}=\mathrm{H}$

Cholesterol Sulphate (14b) $\mathrm{R}=\mathrm{SO}_{3}{ }^{-}$

Figure 7. Some other representative Mincle ligands

Taken together, this collection of Mincle ligands highlights the ability of the Mincle binding site to accommodate a variety of ligands, and this diversity of ligands makes it difficult to predict whether a compound will be a good Mincle ligand based on structure alone. Furthermore, binding affinity does not directly correlate to a functional immune response, and therefore it is important to assess Mincle 
agonist activity in biological assays. ${ }^{50}$ Ultimately, the ligands need to be evaluated in vivo, as in vitro immune profiles can be different from the in vivo profiles. For instance, a synthetic glucose monomycolate was shown to cause BMMs to produce similar levels of cytokines as TDB in vitro, however in mice vaccination models glucose monomycolate had lower immunostimulatory profile than TDB. ${ }^{71}$ It is important to note that direct comparisons between different classes of Mincle agonists can be difficult to make as compounds need to be tested in the same immunological assay in order to determine whether one class of Mincle ligand is better than the other.

Despite these challenges, some general points can be made in regard to broad structural features which affect Mincle binding and activation. Many Mincle ligands contain carbohydrate moieties, which likely interact with the CRD of Mincle, and lipid groups, which likely bind to the hydrophobic groove. As the hydrophobic groove is rather shallow and open-sided, it is not so surprising that Mincle binds both linear and bulkier branched lipids. ${ }^{50,65-66}$ Lipid length appears to have the most influence on Mincle activation, as demonstrated via atty acid diester studies, whereby the lipid must be $\geq 12$ carbon atoms long to activate macrophages to produce cytokines and chemokines. ${ }^{49,68}$ Subtle changes to the functional groups within the lipid can also subtly alter the immune response. ${ }^{50}$ This is perhaps best illustrated in studies with synthetic TDMs, whereby systematic variation of cyclopropane, methoxy-, keto- and hydroxy- groups altered the levels of TNF- $\alpha$ produced by bone marrow derived dendritic cells (BMDCs), ${ }^{71}$ although the exact effect of functional group on immune response is not well understood. Therefore, when selecting synthetic carbohydrate-based ligands to prepare as potential Mincle agonists, long lipids should be included and subtle variations in the structure made to explore the exact effect of structure on the immune response. Advances in understanding of non-carbohydrate derived Mincle ligands have also been made, particularly highlighting the species difference of Mincle homologs ${ }^{50}$ Namely, cholesterol and glycerol monomycolate have both been found to be hMincle, but not mMincle, agoinsts. ${ }^{74,78}$ This further emphasises the importance of examining Mincle ligands in a range of assays.

\subsubsection{Macrophage C-type lectin (MCL)}

The expression levels of Mincle in a resting macrophage are very low, however TDM stimulation increases Mincle mRNA expression. ${ }^{80}$ It was therefore hypothesised that a second receptor might also recognise TDM and that activation of this receptor upregulated Mincle expression. ${ }^{80}$ Accordingly, by screening gene sequences for sequence homology to Mincle, Macrophage C-type lectin (MCL, Clec4e, ClecSf9), a CTL constitutively expressed on macrophages and DCs, was identified. MCL was then 
shown to bind plate coated TDM and to enhance Mincle-dependent cytokine production and the adjuvancy of TDM. ${ }^{80-81}$ Thus, MCL was identified as the second receptor of TGLs, though the mechanism of the MCL signalling pathway is still unclear.

From immunoprecipitation experiments, MCL is known to signal through Syk. ${ }^{82}$ In addition to Syk, MCL has also been coimmunoprecipitated with $\mathrm{FcR} \gamma$, suggesting that MCL signals via a similar pathway to Mincle ${ }^{80}$ However, it is unclear how MCL interacts with FcR $\gamma$, as FcR $\gamma$ usually binds via a positively charged amino acid residue, which MCL lacks. ${ }^{64}$ Notwithstanding, the hydrophilic amino acid, threonine, at position 38 of the MCL protein has been found to be essential for the FcR $\gamma$ interaction. ${ }^{80}$

The experiments performed thus far are suggestive of Mincle/MCL cooperation to recognise TGLs, but this interaction is still not fully understood. As MCL has been shown to be essential for the upregulation of Mincle mRNA following TDM stimulation, it has been hypothesised that MCL initially recognises TDM and causes Mincle expression to increase. ${ }^{80}$ However, Mincle expression is required for MCL expression on bone marrow derived DCs. ${ }^{83-84}$ There is also evidence to suggest that Mincle and MCL form a heterodimer, as Mincle and MCL co-precipitate with FcR $\gamma$ antibodies, ${ }^{84}$ with the stalk portion of Mincle being crucial for the dimer formation. ${ }^{83}$

Due to the proposed cooperation between Mincle and MCL, it is important to have some understanding of the structure of MCL when designing Mincle ligands. A crystal structure of bovine MCL shows that, ${ }^{65}$ similar to Mincle, MCL has a CRD that contains $\mathrm{Ca}^{2+}$. However, in contrast to Mincle, MCL has an unusual glutamic acid-proline-aspartic acid (EPD) motif. Like Mincle, MCL also has hydrophobic residues extending away from the CRD region that are proposed to bind the long lipid chains of TDM and other TGLs. ${ }^{65}$ Due to the similarity of Mincle and MCL crystal structures, it is likely that a ligand designed for Mincle binding will also sufficiently activate MCL.

\subsection{Trehalose amide glycolipids}

The physiological stability, and hence immunostimulatory activity, of TGL Mincle ligands could potentially be improved by substituting the ester linkages in TGLs for amide linkages. Chemical or enzymatic hydrolysis at carbonyls is a degradation pathway of many drugs, and amides are less prone to hydrolysis than their ester counterparts. ${ }^{85-86}$ The additional stability of amides is due to the nitrogen lone pair donating electron density to the carbonyl group providing significant stabilisation. During 
hydrolysis, this stabilising interaction is in the formation of transition state that leads to the tetrahedral intermediate, thus creating a large energetic barrier for hydrolysis. ${ }^{87}$ As a result, amides often have long half-lives, with a half-life of 7 years being measured for a peptide bond in water $(\mathrm{pH}=7){ }^{88}$ Despite this, all TGLs thus far investigated as Mincle agonists contain lipid esters at either one or both of the 6- and 6'-positions of trehalose. Similarly, non-TGL Mincle ligands that bind the CRD of Mincle also all contain ester linkages. Replacing the ester linkages of TGLs with amide bonds may increase the physiological stability of the ligands. This, in turn, may result in increased in vivo efficacy of the compounds.

To date, several trehalose amide glycolipids have been prepared, however, only one such derivatives (prepared by the Stocker-Timmer group) has been tested for its ability to activitate APCs in a Mincledependent manner. ${ }^{89}$ Here the trehalose probe 15 (Figure 8), which contains an amide bond to a fluorescent reporter group, was used to monitor the cellular uptake of ligands. ${ }^{89}$ Probe $\mathbf{1 5}$ caused Mincle-dependent nitrous oxide production in BMMs, but as trehalose monoesters also activate macrophages, it is plausible that the fatty acid ester, and not the fluorescent reporter group, bound to the major hydrophobic groove in Mincle. ${ }^{70}$ The amide derivative of brartemicin 16 retained biological activities of cancer cell cytotoxicity and the inhibition of cancer cell invasion, ${ }^{90}$ while very recently bioorthogonal probe $\mathbf{1 7}$ has been used to study mycobacterial cell wall biosynthesis. ${ }^{91}$ Probe $\mathbf{1 7}$ was incorporated into the cell wall of Mycobacterium smegmatis in an antigen 85 complex dependent manner and was detected by fluorophore conjugation to the probe. Therefore, it appears that the substitution of ester groups with amide groups in TGLs does not adversely affect cell and protein recognition in many cases. This bodes well for the potential of trehalose amide glycolipids to activate Mincle and act as a promising new class of Mincle agonists. 


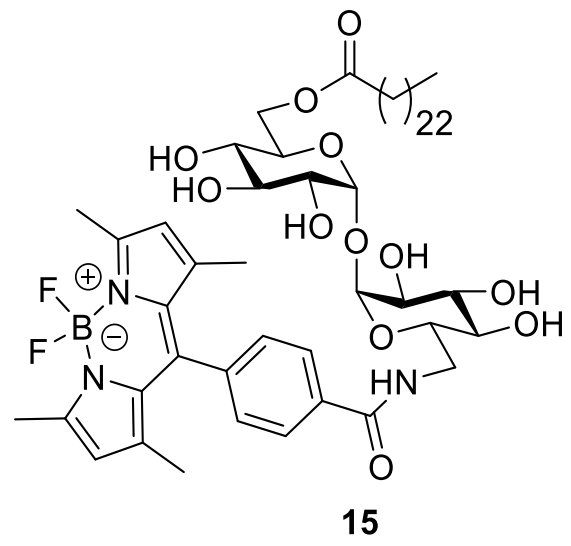

15

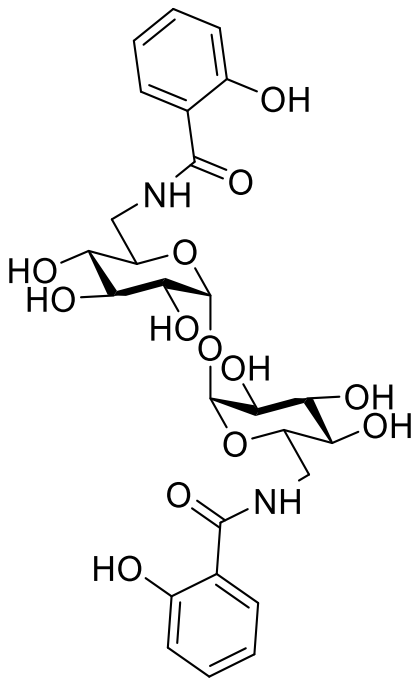

16

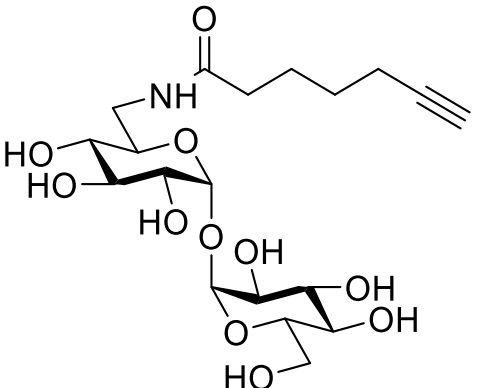

17

Figure 8. Trehalose amide derivatives.

Current SARs and crystallographic data can also be used to postulate that amide functionalised TGLs will be Mincle agonists. With regards to SARs, Mincle has been activated by a large range of lipid structures, from straight chain fatty acids of TDB to more functionalised derivatives such as TDM and the maradolipids. ${ }^{44,49,60}$ Moreover, the crystal structures of Mincle suggest that the amide should bind at the entrance to the hydrophobic groove. ${ }^{65-66}$ As the hydrophobic groove is where the lipid, which can be widely structurally varied, binds, it is plausible that a modification from ester to amide should also be accepted without loss of Mincle dependent activity. However, it remains to be experimentally determined whether trehalose amide glycolipids are Mincle agonists. 


\subsection{Project Aims}

The aim of this thesis is to develop a synthetic route to prepare libraries of trehalose amide glycolipids with the general structure 18 (Figure 9). The target structures have $\alpha, \alpha^{\prime}$-trehalose at their core, with the 6- and 6'-positions functionalised with an amide bound lipid. The libraries of trehalose amide glycolipids will then be screened for their ability to activate murine and human Mincle using the nuclear factor of activated T-cells (NFAT)-GFP reporter assay; ${ }^{60}, 92$ with the most promising candidates being further assessed for their potential adjuvant activity using murine bone marrow derived macrophages (BMMs) or human monocytes derived from peripheral blood mononuclear cells (PBMCs).

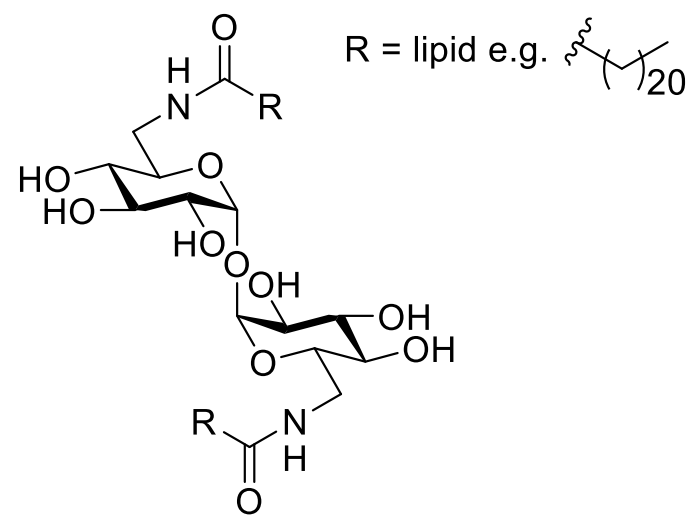

18

Figure 9. General structure of target trehalose amide glycolipids 


\section{Straight chain trehalose amide glycolipids}

\subsection{Target trehalose amide glycolipids}

To synthesise trehalose amide glycolipids as potentially more physiologically stable Mincle ligands, a first library of trehalose amide glycolipids containing straight chain fatty acids of different lengths (1ac) and cis-double bonds in the lipid chain (1d and 1e) were selected as the target compounds (Figure 10). The unsaturated derivates (1a-c) will be used to determine whether amide-functionalised TGLs mimic the pattern of Mincle agonist activity observed for trehalose diesters of straight chain fatty acids, whereby lipid chains of $\geq \mathrm{C} 12$ lead to Mincle agonist activity. ${ }^{49,68-69}$ The unsaturated compounds, 1d and 1e, will be prepared to investigate whether lipid conformation is important for Mincle binding and activation. Lipids containing cis-double bonds, particularly the single site of unsaturation in $\mathbf{1 d}$, have been observed in the maradolipids, ${ }^{44}$ although such maradolipids have not been tested for their ability to activate Mincle. Accordingly, this first library of trehalose amide glycolipids will allow the potential of trehalose amide glycolipids as Mincle agonists to be assessed and offer some key insights into structure-activity relationships.

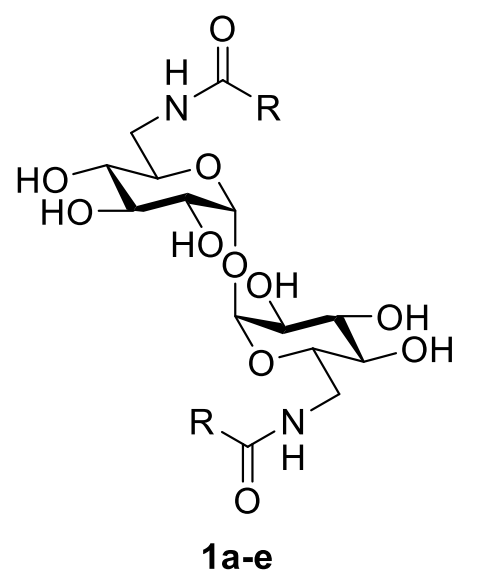

$$
\begin{aligned}
& \mathrm{R}={ }^{\mathrm{a}} n=2 ; \mathbf{b} n=16 ; \mathbf{c} n=20
\end{aligned}
$$$$
\mathrm{d} R=\mathrm{s}^{\mathrm{s}}+\mathrm{T}_{7}=\mathrm{Y}_{7}
$$

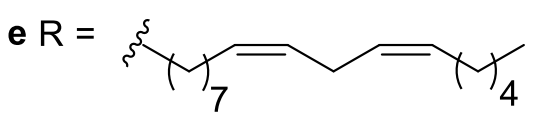

Figure 10. First trehalose amide glycolipid library 


\subsection{Synthetic Strategy}

The retrosynthetic plan for amide-functionalised TGLs 1a-e is shown in Scheme 1. Here the targets 1a-e should be accessible by coupling di-amine 19 with the appropriately functionalised, commercially available carboxylic acids 20a-e. The di-amine 19 can, in turn, be synthesised from $\alpha, \alpha^{\prime}$-trehalose 21 via selective iodination at $\mathrm{C}^{6}$ and $\mathrm{C}^{\prime}$, substitution of the iodo-groups for azides, and the subsequent reduction of the azide functionalities to amine groups.

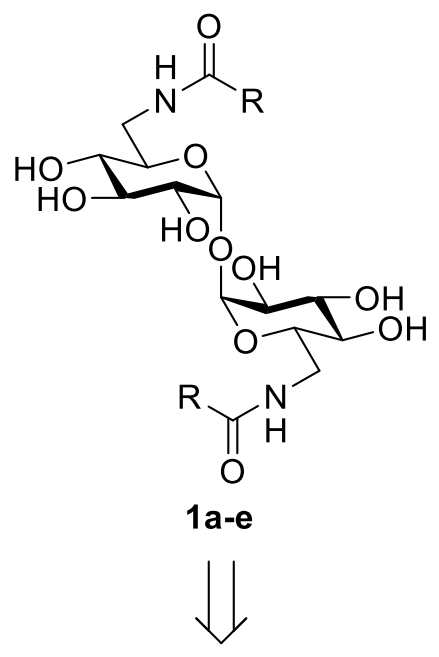

$$
\begin{aligned}
& \mathrm{R}=\mathrm{S}^{\mathrm{s}} \mathrm{Y}_{n} \\
& \quad \mathrm{a}=2 ; \mathbf{b} n=16 ; \mathbf{c} n=20
\end{aligned}
$$

$\mathrm{dR}=\mathrm{s}^{\mathrm{s}}+\mathrm{Y}_{7}=\mathrm{M}_{7}$

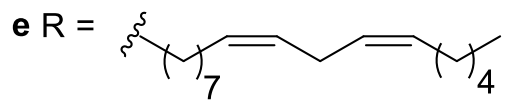

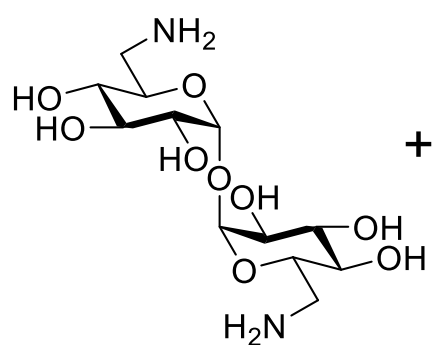

19
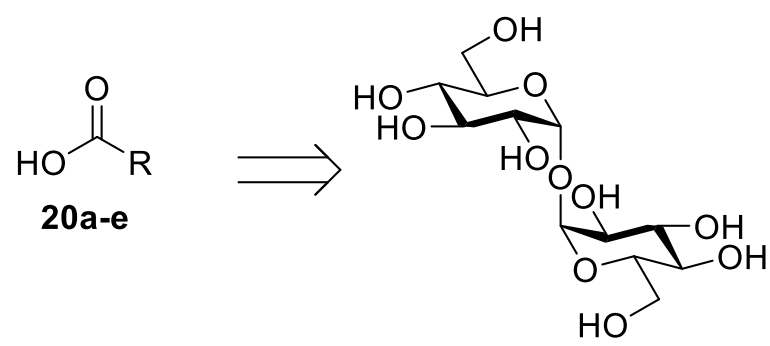

21

Scheme 1. Retrosynthesis of straight chain amide TGLs.

The proposed synthetic route has a few advantages. Specifically, the route does not require the protection of the secondary hydroxyls of trehalose, unlike other reported synthesises of amidefunctionalised trehalose compounds. ${ }^{90}$ The use of protecting groups increases the number of synthetic steps, decreases atom efficiency, and often leads to poorer overall yields, so should be avoided when possible. In this instance, protecting groups are likely to be unnecessary, as the primary hydroxyls of 
trehalose can be selectively substituted for iodides, ${ }^{93-94}$ thereby distinguishing the 6- and 6'-positions for the formation of the desired di-amine (19). Moreover, once the amine groups are installed, the coupling reagent 2-(1H-benzotriazole-1-yl)-1,1,3,3-tetramethyluronium hexafluorophosphate (HBTU) should allow for the selective formation of amide rather than ester bonds. HBTU is a uronium salt, a class of peptide coupling reagent commonly used for amide bond formation. ${ }^{95}$ While there are a few accounts of using uronium salts for esterification reactions, the reagents show selectivity towards primary hydroxyls, with esterification of secondary hydroxyls only occuring when a greater excess of the carboxylic acid, the uronium salt and the organic base are present. ${ }^{96-97}$ Thus, by limiting reagent equivalents in the coupling reaction, it should be possible to selectively form amides instead of esters by virtue of the higher nucleophilicity and reduced steric hindrance of the primary amines.

\subsection{Synthesis of 6,6'-diazido-6,6'-dideoxy- $\alpha, \alpha^{\prime}$-trehalose}

With a synthetic strategy in place, efforts towards the synthesis of the key intermediate, 6,6'-diazido6,6'-dideoxy- $\alpha, \alpha^{\prime}$-trehalose (23), were first undertaken. This di-azide intermediate will be reduced to di-amine 19, and the latter will be used without purification due to the inherent difficulties in purifying fully deprotected amines. To this end, it was envisioned that $\alpha, \alpha^{\prime}$-trehalose $\mathbf{2 1}$ would first be selectively iodinated at the 6- and 6'-positions via the use of $\mathrm{I}_{2}$ and triphenylphosphine $\left(\mathrm{PPh}_{3}\right)$ to give di-iodide 22 according to literature procedures (Scheme 2). ${ }^{93,98-101}$ 


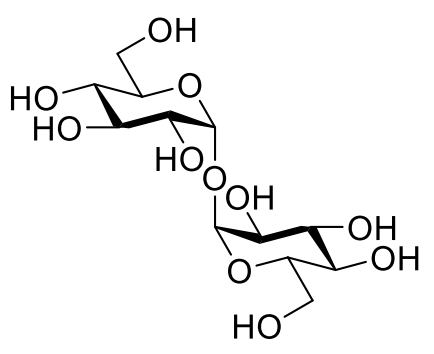

21

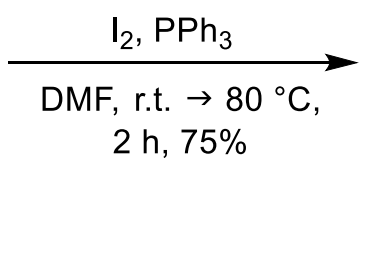

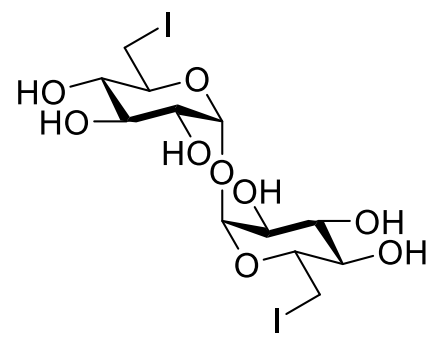

22

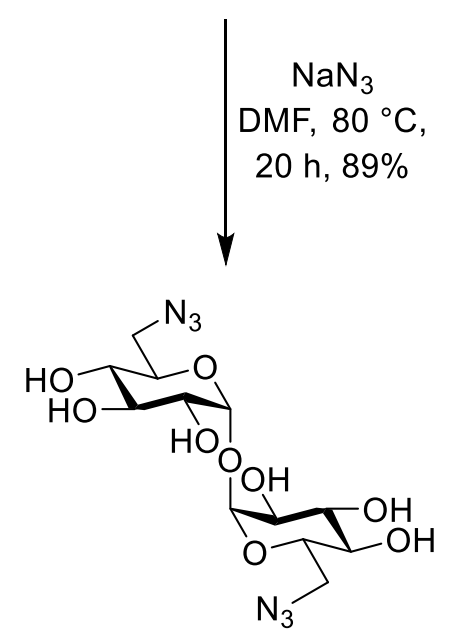

23

Scheme 2. Synthesis of di-azide 23

While the iodination reaction itself proceeded smoothly according to thin layer chromatography (TLC) analysis, with the disappearance of trehalose $\left(\mathrm{R}_{f}=0.11,4: 1 \mathrm{EtOAc}: \mathrm{MeOH} v / v\right)$ and the formation of a new product $\left(\mathrm{R}_{f}=0.50\right.$, 4:1 EtOAc: $\left.\mathrm{MeoH} v / v\right)$, purification of 22 proved challenging. Upon completion of the reaction, and quenching with $\mathrm{MeOH}$, most literature procedures report purification by trituration with water to remove $\mathrm{PPh}_{3}$ and $\mathrm{O}=\mathrm{PPh}_{3}{ }^{93,}{ }^{98-101}$ In trying to replicate this, many trituration conditions were attempted, with changes being made to the temperature of the water that was added and the order of addition (i.e. water added to the reaction vessel or vice versa). The best result was obtained by pouring the reaction mixture into vigorously stirred room temperature water, however, unacceptable levels of iodine, $\mathrm{PPh}_{3}$ and $\mathrm{O}=\mathrm{PPh}_{3}$ were still observed in the product mixture. This in turn resulted in variable yields, negatively impacting the next synthetic step. Additionally, extracting the aqueous filtrate with $\mathrm{CH}_{2} \mathrm{Cl}_{2}$, based on a reported modification to the procedure, ${ }^{99}$ did not improve the purity of the final product. Indeed, the observation that $\mathbf{2 2}$ could not be obtained in sufficient purity following trituration alone was supported by some literature procedures, whereby one 
procedure used high performance liquid chromatography (HPLC) following trituration to remove $\mathrm{O}=\mathrm{PPh}_{3},{ }^{100}$ to the detriment of the yield ( $29 \%$ versus $71-83 \%$ in other methods). Therefore, none of the purification techniques reported thus far were suitable to obtain high purity product in a good yield.

To optimise the purification of $\mathbf{2 2}$, different chromatography techniques following trituration were trialled. Silica gel flash column chromatography was unsuitable as the very polar product could not be readily loaded onto the column and separation of the product from iodine and $\mathrm{O}=\mathrm{PPh}_{3}$ was poor, as evidenced by low to moderate yields $(17-52 \%)$ of the target compound. Accordingly, following trituration with water, the polyaromatic resin HP20, which apolar molecules adhere to, was then used to perform reverse-phase chromatography on the resulting product mixture. To this end, the crude product mixture was loaded onto the column in water and, following gradient elution $\left(\mathrm{H}_{2} \mathrm{O}\right.$ to $1: 1$ $\left.\mathrm{H}_{2} \mathrm{O}: \mathrm{MeOH} v / v\right)$, the residual apolar impurities $\left(\mathrm{O}=\mathrm{PPh}_{3}\right.$ and iodine $)$ could be separated from the desired product to give 22 in good (75\%) yield. Moreover, this purification strategy could be performed on a scale of several grams.

Upon obtaining 22, the compound was fully characterised by nuclear magnetic resonance (NMR), infrared (IR) spectroscopy, high resolution mass spectrometry (HRMS), and optical rotation measurements. This is the first full characterisation of this product in a single report, ${ }^{93,98-99}$ which may in part be due to the failings of the purification methodologies reported by others. To confirm that the 6- and 6'- positions were iodinated, a heteronuclear single quantum correlation (HSQC) experiment was used. Here, the methylene resonances, which are observed for the protons at the 6- and 6'positions, correlated with the carbon signal at $\delta 6.3 \mathrm{ppm}$ in the HSQC (Figure 11). This upfield shift of the carbon resonance is characteristic of a carbon bound to an iodine atom, as the large electron cloud surrounding iodine shields the carbon nuclei from the magnetic field. As this was the only signal to be shifted upfield, and the HSQC confirmed it as the 6- and $6^{\prime}$ - positions, it was concluded that the iodo-groups had been successfully installed selectively on the 6- and 6'-postions of trehalose. Other spectral data and full characterisation also supported this assignment (see experimental section). 


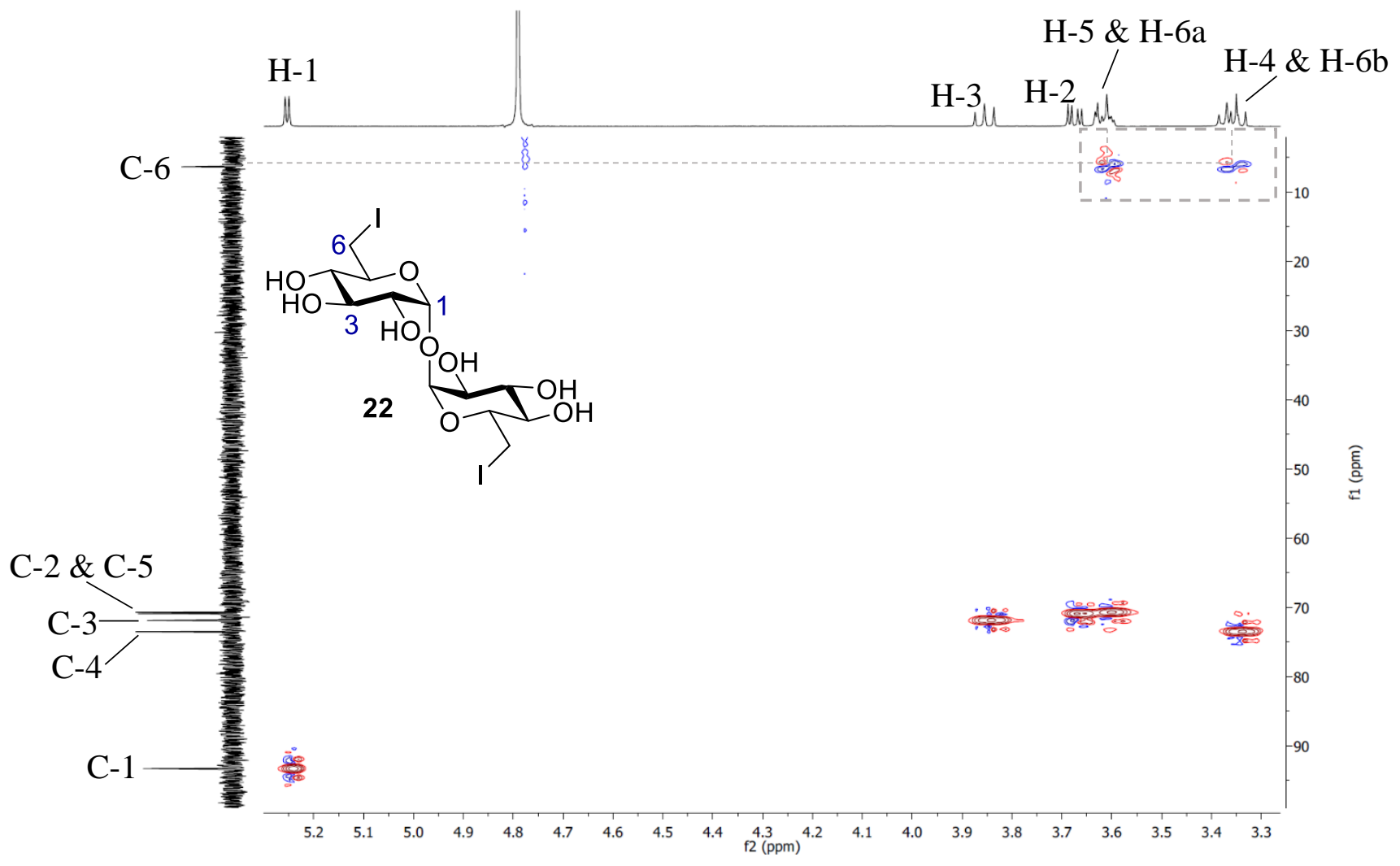

Figure 11. HSQC of 6,6'-dideoxy-6,6'-diiodo- $\alpha, \alpha^{\prime}$-trehalose (22)

To explain the synthesis of di-iodide 22 from $\alpha, \alpha^{\prime}$-trehalose using $\mathrm{PPh}_{3}$ and iodine as regents, the reaction begins with nucleophilic attack of $\mathrm{PPh}_{3}$ (I) on iodine (II), generating iodophosphonium iodide (III) (Scheme 3). Nucleophilic attack of the primary hydroxyl of trehalose 21 on the iodophosphonium iodide (III) forms intermediate IV with the loss of HI. Nucleophilic attack of I $^{-}$on IV produces the mono-iodide of trehalose $\mathbf{V}$ with triphenylphosphine oxide (VI) being formed as a by-product. 


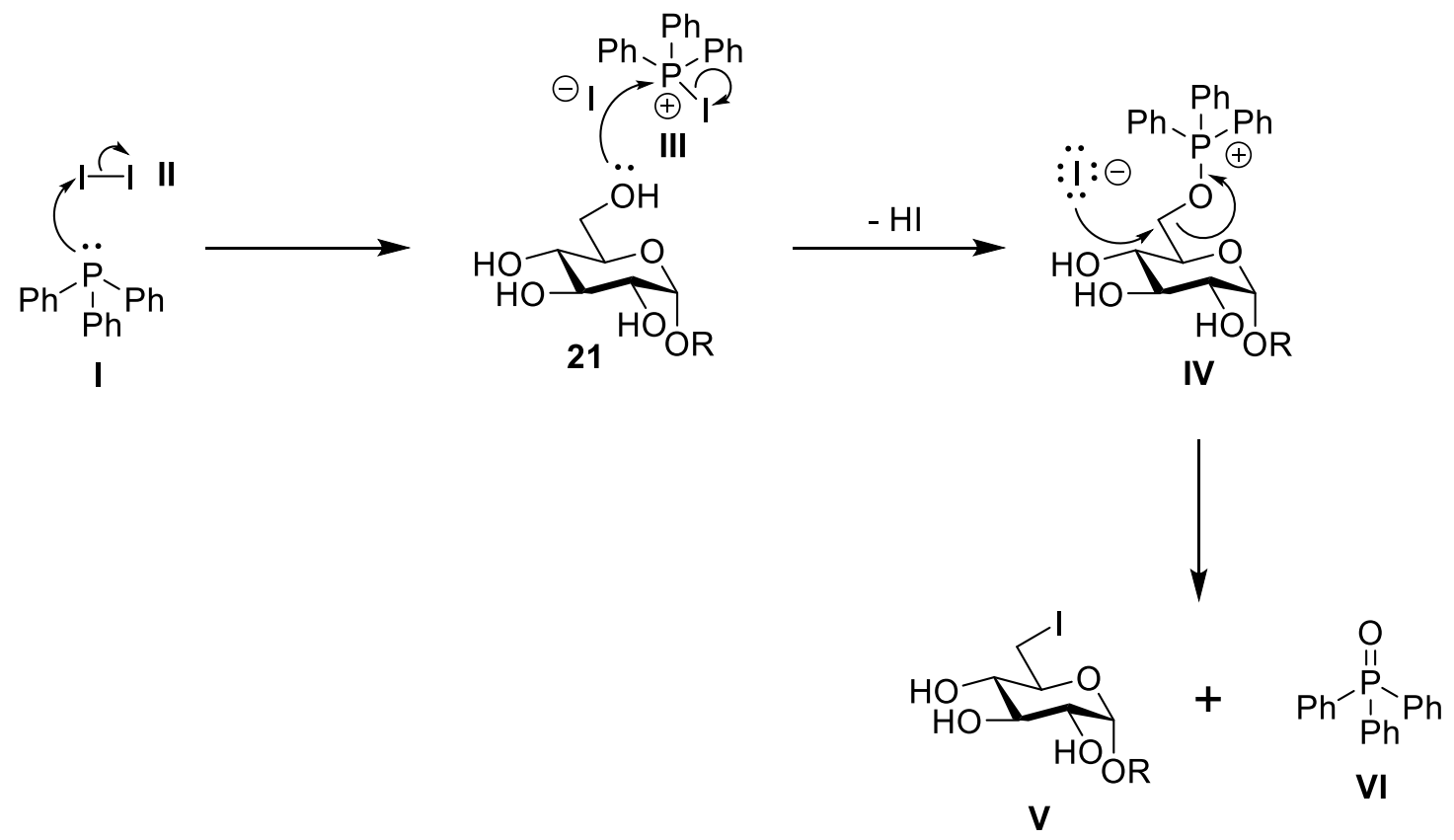

Scheme 3 Mechanism of the iodination reaction

With a good supply of high purity $\mathbf{2 2}$ secured, efforts were then made towards the synthesis of di-azide 23 (Scheme 2). Once again, this is a literature reported procedure, however the variety of purification methodologies reported indicated potential difficulties with the purification of the target compound. Following treatment of di-iodide 22 with $\mathrm{NaN}_{3}$, Srinivasachari et al..$^{98}$ filtered the residual salts and only purified an analytical sample via recrystallisation with 2-propanol, while Reineke et al. ${ }^{99}$ removed salts using an ion exchange resin, and Fernández et al. ${ }^{93}$ reported no purification at all.

As per the iodination reaction, the reaction to form di-azide $\mathbf{2 3}$ proceeded well, as indicated by TLC analysis, although purification of the target compound did need to be optimised. The reported recrystallisation in 2-propanol, ${ }^{98}$ did not allow for good product recovery when performed on larger samples. Silica gel flash column chromatography was unsuitable as the polar product 21 was challenging to load and did not give good separation between $\mathbf{2 3}$ and the residual iodine. Consquently, purification of di-azide 23 by reverse-phase HP20 chromatography $\left(\mathrm{H}_{2} \mathrm{O}\right.$ to $\left.1: 1 \mathrm{H}_{2} \mathrm{O}: \mathrm{MeOH} v / v\right)$ was attempted, the crude product was loaded in water, and by eluting with water, the residual salts could be removed. The product was then eluted as a single compound using 1:1 $\mathrm{H}_{2} \mathrm{O}: \mathrm{MeOH}(v / v)$, and following lyophilization, di-azide $\mathbf{2 3}$ was isolated in high purity and in an excellent (89\%) yield (literature reported values range from $37-93 \%) .{ }^{93,98-99}$ 


\subsection{Staudinger reduction and coupling reaction}

Next, the azide groups in $\mathbf{2 3}$ needed to be reduced in order to form di-amine 19, which could be coupled to a lipid to form the desired amide functionalized TGLs. It was decided that the di-amine $\mathbf{1 9}$ would not be purified and isolated in this synthesis, although isolation of $\mathbf{1 9}$ and the dihydrochloride salt of 19 have been reported, purification of this material involved trituration with water to remove $\mathrm{PPh}_{3}$ and triphenylphosphine oxide followed by purification using anion exchange resins. ${ }^{93}$, 99 Such methodology would likely prove challenging and may lead to reduced yields. Thus, to avoid this intermediate purification step, it was proposed that the Staudinger reduction of di-azide $\mathbf{2 3}$ could be performed with the use of trimethylphosphine $\left(\mathrm{PMe}_{3}\right)$, rather than $\mathrm{PPh}_{3}$. Since $\mathrm{PMe}_{3}$ is volatile, any excess can be removed in vacuo before performing the coupling reaction. The residual trimethylphosphine oxide formed during the course of the reaction $(\mathbf{2 3} \rightarrow \mathbf{1 9})$, should not interfere with the subsequent coupling reaction and thus did not need to be removed at this stage of the synthesis. It was envisioned that following the treatment of di-azide $\mathbf{2 3}$ with $\mathrm{PMe}_{3}$ and $\mathrm{H}_{2} \mathrm{O}$, the crude di-amine 19 would be subjected to an HBTU-mediated coupling reaction with the appropriate lipid (Scheme 4). 


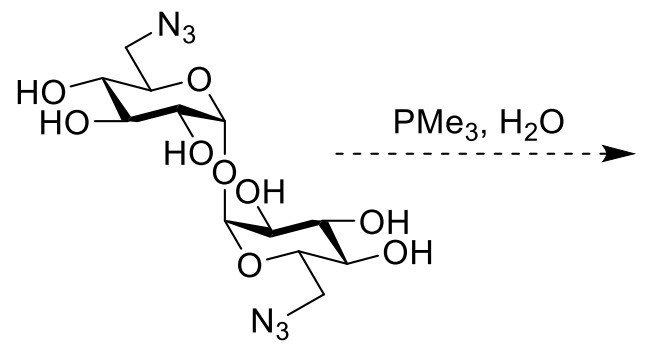

23

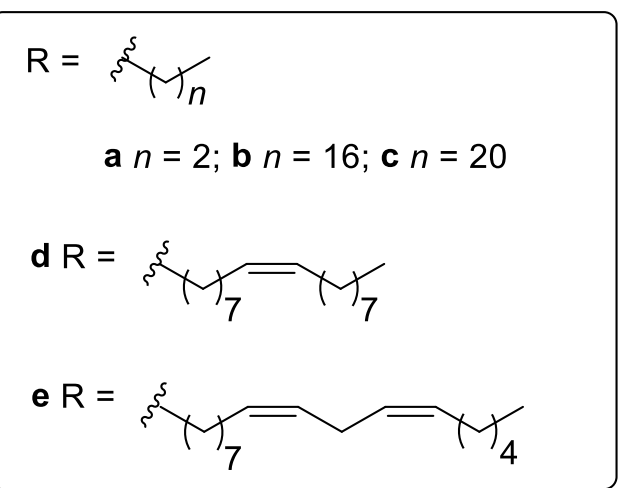

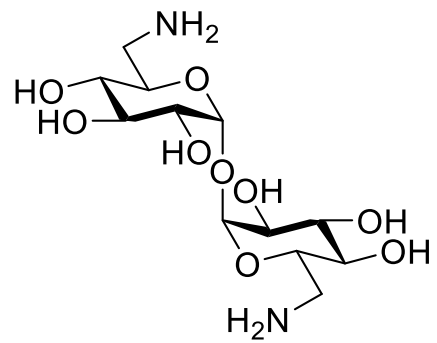

19<smiles>[R]OC(=O)O</smiles>

HBTU, DIPEA

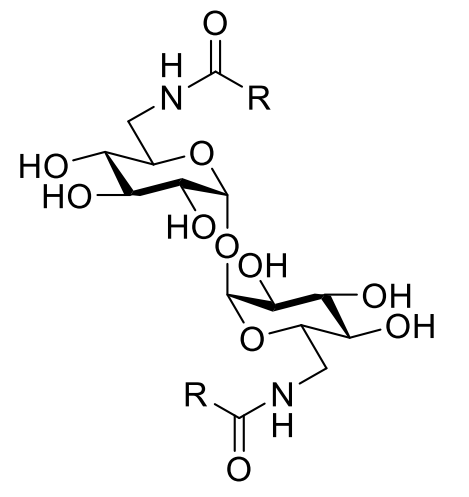

1a-e

Scheme 4. Planned reaction sequence to synthesise 1a-e.

The Staudinger reduction is the reduction of an organic azide by a trivalent phosphine, classically $\mathrm{PPh}_{3}{ }^{102-103}$ The abiotic nature of the reacting groups and the chemoselectivity has led to this reaction being modified to a bioorthogonal ligation used for $i n$-situ labelling of live cells and even mice. ${ }^{104-105}$ Therefore, this reaction is highly suitable for the synthesis of di-amine $\mathbf{1 9}$ with few by-products, which should have minimal effects on the subsequent coupling reaction. Mechanistically, the reaction is initiated by nucleophilic attack of trimethyl phosphine $\mathbf{I}$ on the azide in $\mathbf{2 3}$, which results in the formation of phosphazide II. Intramolecular attack of the nitrogen atom on phosphorous then generates phosphazide III, which re-arranges to release nitrogen gas and form iminophosphorane IV. Hydrolysis of IV then liberates the free amine $\mathbf{V}$ with the production of trimethylphosphine oxide VI (Scheme 5). 


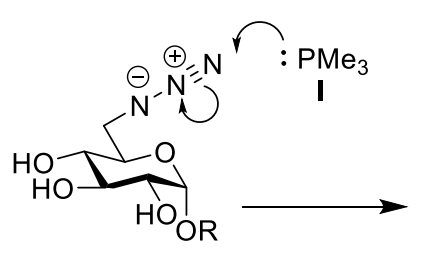

23

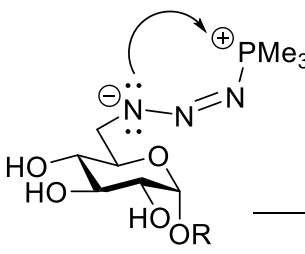

II

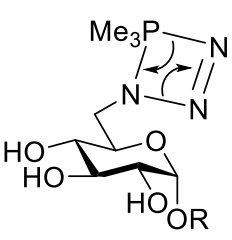

III
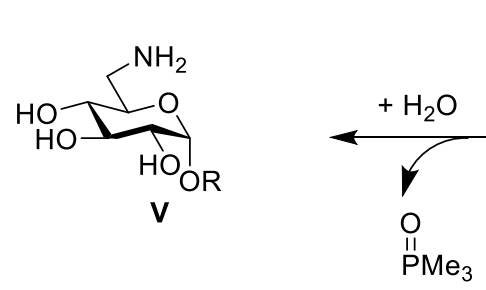

VI

Scheme 5. Mechanism of the Staudinger Reduction. ${ }^{102-104}$

The Staudinger reduction of di-azide 23 to di-amine 19 proceeded well. After 1.5 hours, analysis by TLC revealed the absence of di-azide $23\left(\mathrm{R}_{f}=0.56,4: 1\right.$ EtOAc:MeOH, $\left.v / v\right)$ in the reaction mixture, and the appearance of a more polar spot $\left(\mathrm{R}_{f}=0.70,1: 1: 1: 1: 1, \mathrm{AcOH}:\right.$ pyridine: $\left.{ }^{t} \mathrm{BuOH}: \mathrm{H}_{2} \mathrm{O}, v / v / v / v\right)$. As it was important to confirm that $\mathbf{1 9}$ was being formed before proceeding with the coupling reaction, the formation of 19 was further confirmed by HRMS and NMR. The observed mass of the product was in agreement with the expected mass (HRMS, $m / z$ calcd. for $\left[\mathrm{C}_{12} \mathrm{H}_{24} \mathrm{~N}_{2} \mathrm{O} 9+\mathrm{H}\right]^{+}: 341.1555$ obsd.: 341.1563), while comparison of the ${ }^{1} \mathrm{H}-\mathrm{NMR}$ spectrum of di-azide (23) and di-amine (19), showed that H-6a and H-6b had shifted upfield following the Staudinger reaction (Figure 12). In addition, only one anomeric centre was observed in the ${ }^{1} \mathrm{H}$-NMR spectrum of di-amine 17, indicating that the product is symmetrical, therefore both azide groups had been reduced. 


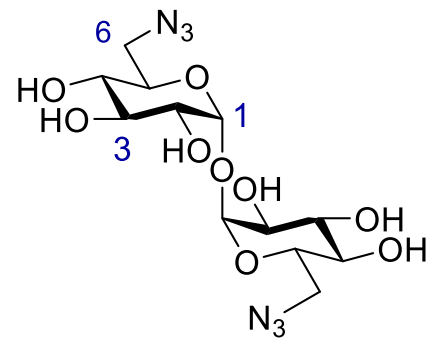

23

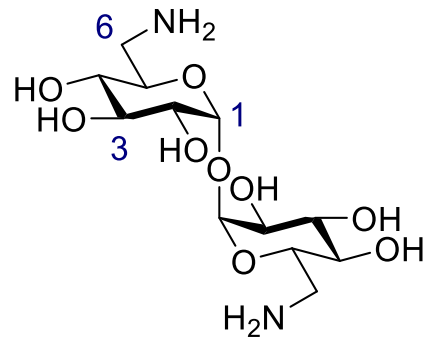

19

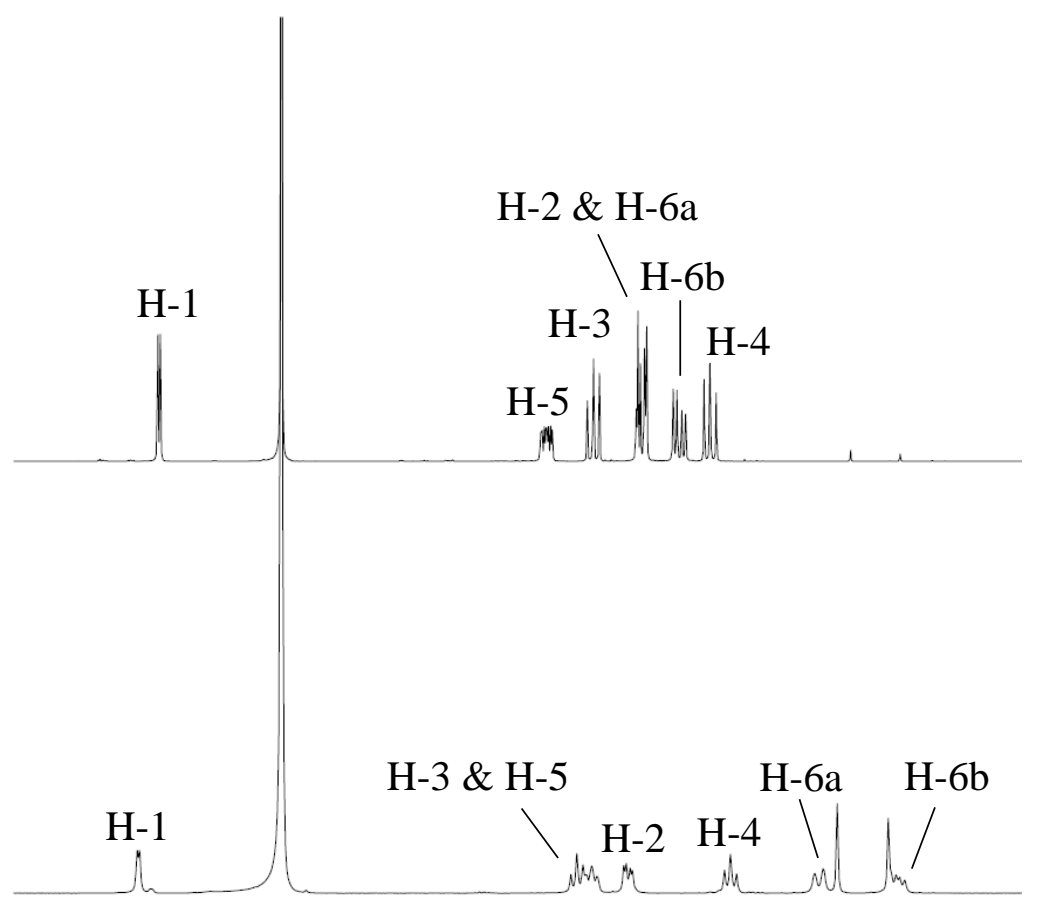

\begin{tabular}{lllllllllllllllll}
\hline 5.6 & 5.4 & 5.2 & 5.0 & 4.8 & 4.6 & 4.4 & 4.2 & 4.0 & 3.8 & 3.6 & 3.4 & 3.2 & 3.0 & 2.8 & 2.6
\end{tabular}

Figure 12. Comparison of ${ }^{1} \mathrm{H}-\mathrm{NMR}\left(500 \mathrm{MHz}, \mathrm{D}_{2} \mathrm{O}\right)$ spectra of di-azide 23 (top) and di-amine 19 (bottom)

With confirmation that the Staudinger Reduction was producing the di-amine 19, coupling to stearic acid (C18 lipid) was then undertaken. Initial reaction optimisation was perforemd using stearic acid, as coupling reactions with fatty acids containing 18 carbons or fewer have been previously shown to proceed with better yields then their longer chain counterparts. ${ }^{49}$ The coupling reaction was first attempted using dimethylformamide (DMF) as the solvent, with the reaction mediated by HBTU and the organic base $N, N$-diisopropylethylamine (DIPEA). Unfortunately, using these conditions, none of the target product $\mathbf{1 b}$ could be isolated (Entry 1, Table 1). It was postulated that the reaction was not yielding the desired product due to solubility issues, as undissolved white solid was observed in the reaction mixture, and there is a large difference in polarity between very polar di-amine $\mathbf{1 9}$ and lipophilic stearic acid. In an attempt to improve solubility, the reaction was repeated in DMF at $60{ }^{\circ} \mathrm{C}$, however, once again, no product could be isolated (Entry 2, Table 1). Therefore, it was decided to trial other solvent systems. 
Table 1. Selected conditions in the optimisation of the coupling reaction

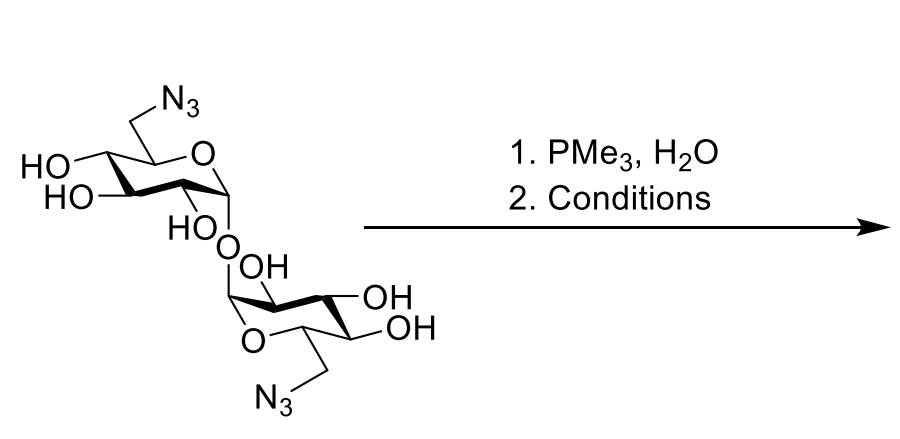

23

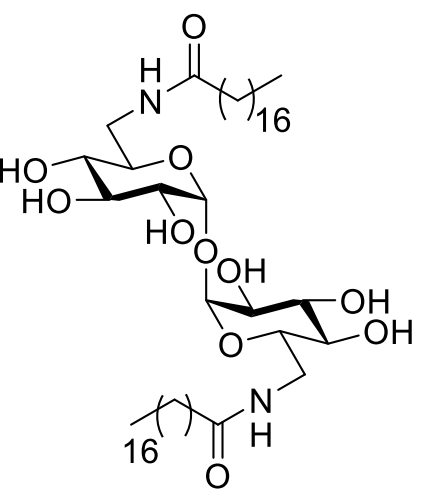

1b

\begin{tabular}{ccccc}
\hline Entry & Reagents & Solvent & Temperature $^{\text {Yield }^{a}}$ \\
\hline 1 & HBTU, DIPEA & DMF & RT & $0 \%$ \\
2 & HBTU, DIPEA & DMF & $60{ }^{\circ} \mathrm{C}$ & $0 \%$ \\
3 & HBTU, DIPEA & $2: 1 \mathrm{CH}_{2} \mathrm{Cl}_{2}: \mathrm{DMF}(v / v)$ & $\mathrm{RT}$ & $0 \%$ \\
4 & HBTU, DIPEA & $4: 2: 1$ Toluene:DMF:MeOH $(v / v / v)$ \\
5 & HBTU, DIPEA & RT & $23 \%$ \\
& & Pyridine & RT & $81 \%$ \\
6 & HBTU & Pyridine & RT & $58 \%$ \\
\hline
\end{tabular}

${ }^{a}$ Isolated Yield, ${ }^{b}$ Includes mass of impurities

Initially it was proposed that stearic acid was not sufficiently solubilised in DMF. To this end a $\mathrm{CH}_{2} \mathrm{Cl}_{2}$ and DMF mixture was used as the solvent, but despite the lipid and di-amine $\mathbf{1 9}$ appearing to be dissolved by eye, once again no product was isolated (Entry 3, Table 1). Accordingly, the more polar solvent mixture of toluene:DMF:MeOH $(4: 2: 1 v / v)$ was used, and, these conditions resulted in some product being isolated, albeit in low yield (Entry 4, Table 1). The product also contained impurities that could not be removed by silica gel flash column chromatography alone. It was postulated that although methanol seemingly improved the solubility of di-mine 19, it could potentially react with the activated carboxylic acid, which would result in a lower yield of the target product. Thus, a non- 
nucleophilic solvent that was polar enough to dissolve the di-amine 19 was anticipated to improve the yield.

In investigating a more appropriate solvent, it was noted that Paul et al. ${ }^{97}$ directly esterified the 6- and $6^{\prime}$-positions of unprotected trehalose using pyridine as a solvent. Based on this observation, the coupling of di-amine 19 to steric acid was repeated in freshly distilled pyridine (Entry 5, Table 1). Here, TLC analysis indicated that the same product as that previously isolated when using toluene:DMF:MeOH as a solvent system was observed $\left(\mathrm{R}_{f}=0.55,4: 1, \mathrm{CH}_{2} \mathrm{Cl}_{2}: \mathrm{MeOH}, v / v\right)$. Before purifying the product via silica gel flash column chromatography, an aqueous work up using ${ }^{t} \mathrm{BuOH}:$ EtOAc $(2: 1, v / v)$ to extract the product was performed. Indeed, this combination of reaction and purification conditions yielded the amide-functionalised trehalose glycolipid $\mathbf{1 b}$ in excellent yield (81\% over two-steps).

In further exploring the reaction conditions, it was hypothesised that, as observed by Paul et al. ${ }^{97}$ the reaction may proceed equally well when undertaken with only pyridine being used as the base. Repeating the reaction without DIPEA did lead to pure, isolable product, but with a reduced yield (compare Entry 5 and Entry 6, Table 1). Thus, it was determined that the reaction likely required a stronger base than pyridine for optimum results and that further reactions to form trehalose amide glycolipids would include DIPEA.

To assist with the characterisation of the target trehalose amide glycolipid 1b, HRMS and NMR spectroscopy was undertaken. Evidence for the installation of two lipids onto the trehalose core was obtained by HRMS ( $\mathrm{m} / z$ calcd. for $\left[\mathrm{C}_{48} \mathrm{H}_{92} \mathrm{~N}_{2} \mathrm{O}_{11}+\mathrm{H}\right]^{+}:$873.6774, obsd.: 873.6770). The ${ }^{1} \mathrm{H}-\mathrm{NMR}$ spectrum for $\mathbf{1 b}$ also showed only one signal for the anomeric centres in the molecule, indicating that the product was symmetrical. To confirm that the lipids had been coupled to the correct positions, heteronuclear multiple bond correlation $(\mathrm{HMBC})$ spectroscopy was used. Here, the carbonyl peak $(\delta$ 175.3) correlated to H-6a $(\delta 4.28-4.16)$ and $\mathrm{H}-6 \mathrm{~b}(\delta 3.90)$ of the modified trehalose as well as the first two methylene groups of the lipid, $\mathrm{CH}_{2}-8(\delta 2.41)$ and $\mathrm{CH}_{2}-9(\delta 1.75)$ (Figure 13). The carbonyl signal also correlated to a proton signal at $\delta 8.86$, which was assigned as the $\mathrm{NH}$ proton of the amide group. 


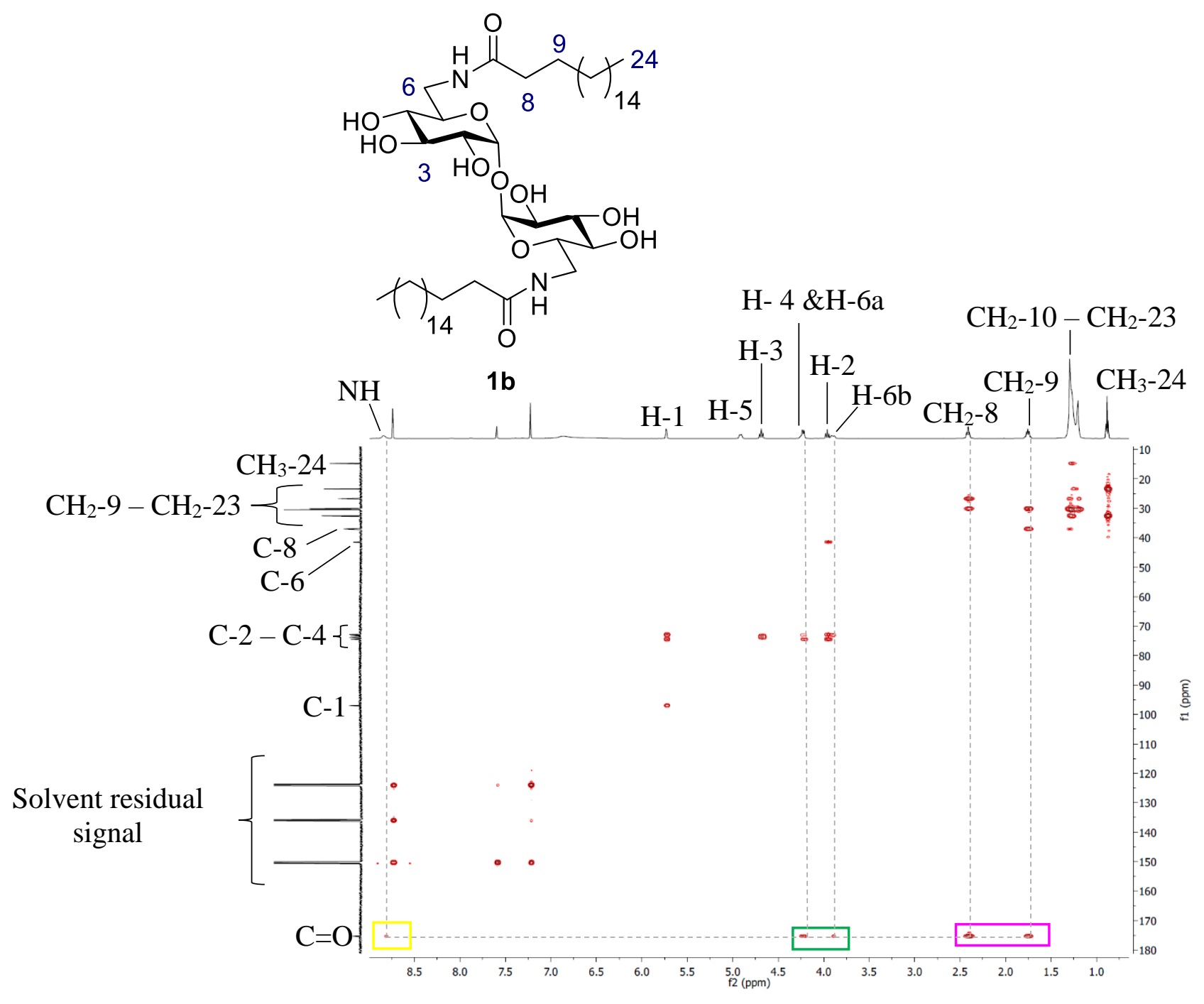

Figure 13. HMBC of trehalose amide glycolipid $\mathbf{1 b .}$

With the successful synthesis of the first target di-amide $\mathbf{1 b}$, synthesis of the other trehalose amide glycolipid library members was attempted. As highlighted above, the C18 di-amide TGL $\mathbf{1 b}$ could be prepared in $81 \%$ over-all yield when using HBTU and DIPEA as the coupling reagents (Entry 1, Table 2). Thus, similar coupling conditions were employed when using behenic acid to prepare the C22diamide 1c (Entry 2). As evidenced by TLC analysis, the coupling reaction of behenic acid to 17 to form 1c proceeded smoothly, however, the longer lipid chain of this behenic acid derivative made the product insoluble in the ${ }^{t} \mathrm{BuOH}: \operatorname{EtOAc}(2: 1, v / v)$ solvent system previously used for the aqueous workup of 1b. Nonetheless, by using hot ${ }^{t} \mathrm{BuOH}$ :ETOAc $(2: 1, v / v)$ for the work up procedure, the desired C22-diamide 1c could be obtained in an excellent (79\%) yield over the two-steps. Next, preparation of di-amide 1d, which contains a single cis-double bond along the $\mathrm{C} 18$ lipid backbone, was undertaken 
(Entry 3). This reaction and the work-up procedure proceeded smoothly to give 1d in a similarly high (80\%) yield. Preparation of di-amide 1e, which contains the lipid derived from linoleic acid, proved more problematic. While the reaction and purification could be performed without too much difficultly to give 1e as a waxy white solid in excellent yield (Entry 4), the product degraded to a yellow oil upon standing at room temperature. ${ }^{1} \mathrm{H}-\mathrm{NMR}$ analysis of the yellow oil showed a loss of the proton resonance at $\delta 5.49 \mathrm{ppm}$, which was assigned to the alkenes in 1e. Unsaturated lipids can undergo autooxidation via the formation of an alkyl radical; skipped dienes, such as linoleic acid, stabilise the alkyl radical and thus facilitate autooxidation at room temperature. ${ }^{106-108}$ Although the degradation product of 1e was not fully characterised, by synthesising the desired product again but carefully storing under argon, away from light and in the freezer, degradation was avoided. 
Table 2. Synthesis of amide functionalised TGLs 1

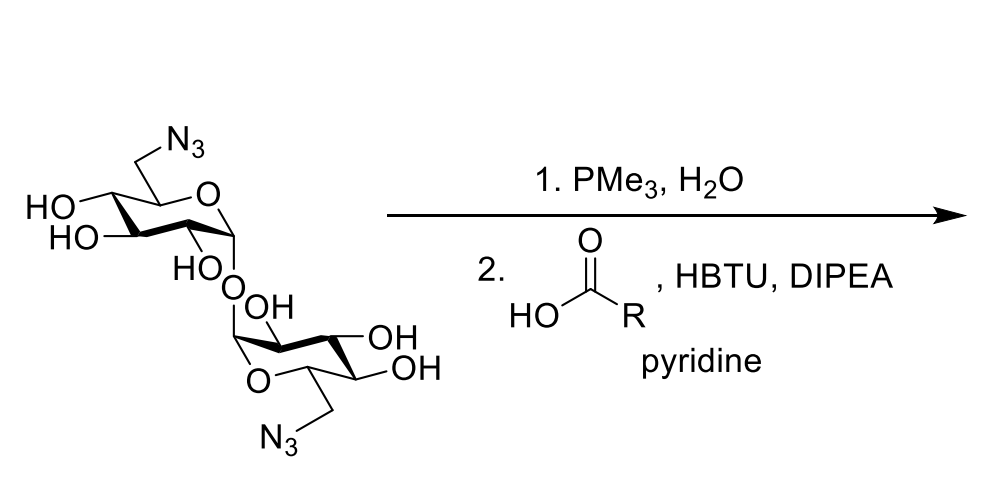

23

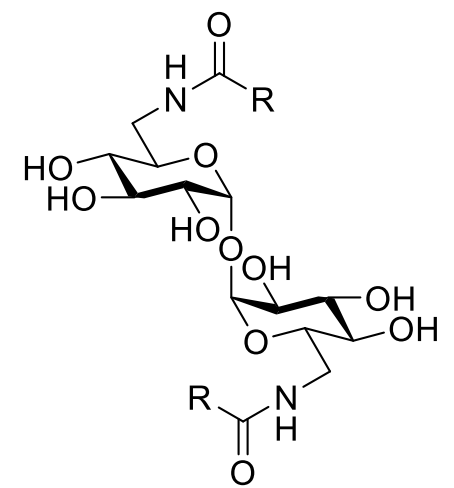

1

\begin{tabular}{|c|c|c|c|}
\hline Entry & Compound & $\mathrm{R}$ & Yield $^{a, b}$ \\
\hline 1 & $1 b$ & & $81 \%$ \\
\hline 2 & 1c & & $79 \%$ \\
\hline 3 & 1d & & $80 \%$ \\
\hline 4 & $1 e$ & & $80 \%$ \\
\hline 5 & $1 a$ & & $0 \%$ \\
\hline
\end{tabular}

${ }^{a}$ Isolated yield, ${ }^{b}$ Yield over two-steps

The last trehalose amide glycolipid target was C4-derivatve 1a. Previous studies have shown that TGLs containing C4 lipid chain esters are not able to activate BMMs, ${ }^{49,68}$ and it would thus be interesting to determine if a similar trend will also be followed for the amide-TGL analogues. To this end, the diamine 19 was treated with butyric acid, HBTU and DIPEA (Entry 5, Table 2), and the reaction progress monitored by TLC. While starting material consumption was observed after 20 hours, with the appearance of a product $\left(\mathrm{R}_{f}=0.45,7: 3 \mathrm{CH}_{2} \mathrm{Cl}_{2}: \mathrm{MeOH} v / v\right)$, the desired product 1a could not be isolated from the reaction mixture in sufficient purity. This was because 1a was reasonably water soluble and thus an aqueous work-up could not be performed to separate the desired product from DIPEA and 1-hydroxylbenzotriazole (HOBT), the latter being the by-product formed from the use of HBTU as a coupling reagent. ${ }^{109}$ 
It was proposed that if the reaction could be performed with a pre-activated carboxylic acid, such as butyric anhydride, the removal of excess DIPEA and HOBT could be avoided. Therefore, following the Staudinger Reduction of di-azide 23, the resultant di-amine 19 was reacted with butyric anhydride (Scheme 6). The reaction was performed in $\mathrm{MeOH}$ to suppress esterification side-reactions. The reaction proceeded smoothly and, following purification by silica gel flash column chromatography, the trehalose amide glycolipid 1a was obtained in an excellent yield (92\% over two steps). Although this procedure gave an excellent yield of the target di-amide TGL 1a, as of yet it has not been applied to the synthesis of di-amide TGLs with long lipids ( $\geq$ C18). However, it is anticipated that the poor solubility of using longer-chain anhydrides maybe problematic for the synthesis of trehalose amides.

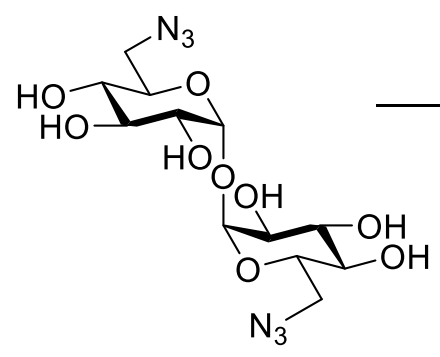

23

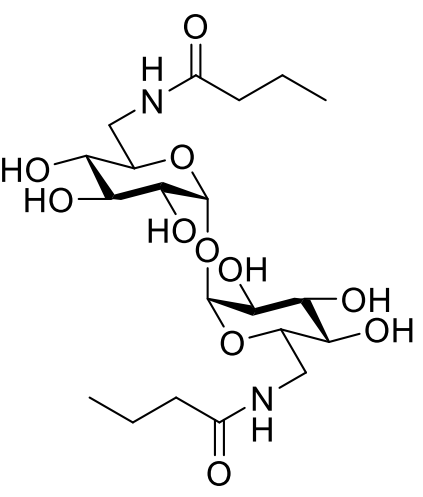

$1 \mathrm{a}$

Scheme 6. Synthesis of amide functionalized TGL 1a 


\subsection{Synthesis of ester analogues}

To directly compare the biological activity of the trehalose amide glycolipids 1a-e to the corresponding di-ester TGLs, glycolipids 24a-d, needed to be prepared (Figure 14). TDB (5), which is the analogous derivative of the $\mathrm{C} 22$-amide 1c, was readily available in the laboratory and thus did not need to be synthesised. To synthesise $\mathbf{2 4 a - d}$ the general synthetic route established by Khan et al. was proposed, whereby appropriately functionalised carboxylic acids were coupled to $2,2^{\prime}, 3,3^{\prime}, 4,4^{\prime}$-hexa- $O$ trimethylsilyl- $\alpha, \alpha^{\prime}$-trehalose. ${ }^{49}$

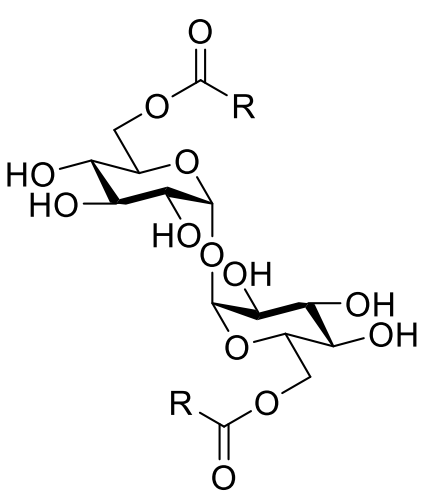

24a-d

$$
\begin{aligned}
& \mathrm{R}=s^{s}+\mathrm{T}_{n} \\
& \text { a } n=2 ; \mathbf{b} n=16 \\
& \text { c } R={ }^{5}+Y_{7}=Y_{7} \\
& \mathrm{dR}=\mathrm{s}^{\mathrm{s}}+\mathrm{C}_{7}=\mathrm{Y}_{4}
\end{aligned}
$$

Figure 14. Trehalose di-ester glycolipids

The preparation of hexa-silylated trehalose is a two-step one-pot reaction, where trehalose is persilylated and then the more labile primary trimethylsilyl (TMS) groups are removed by $\mathrm{K}_{2} \mathrm{CO}_{3}$ treatment. ${ }^{110}$ The silylation reaction begins with the nucleophilic attack of fluoride from tetrabutylamonium fluoride (TBAF) I on the silicon atom of $\mathrm{N}, \mathrm{O}$-bis-trimethylsilylacetamide (BSA II), producing fluorotrimethylsilane III and imidate IV (Scheme 7). The resonance structure of IV with a negatively charged nitrogen atom $(\mathbf{V})$ deprotonates trehalose 21, generating $N$-trimethylsilylacetamide VI and alkoxide VII. Nucleophilic attack of the negatively charged oxygen of VII on the $O$ trimethylsilyl of BSA (II) forms the TMS ether VII, while simultaneously regenerating intermediate IV. 

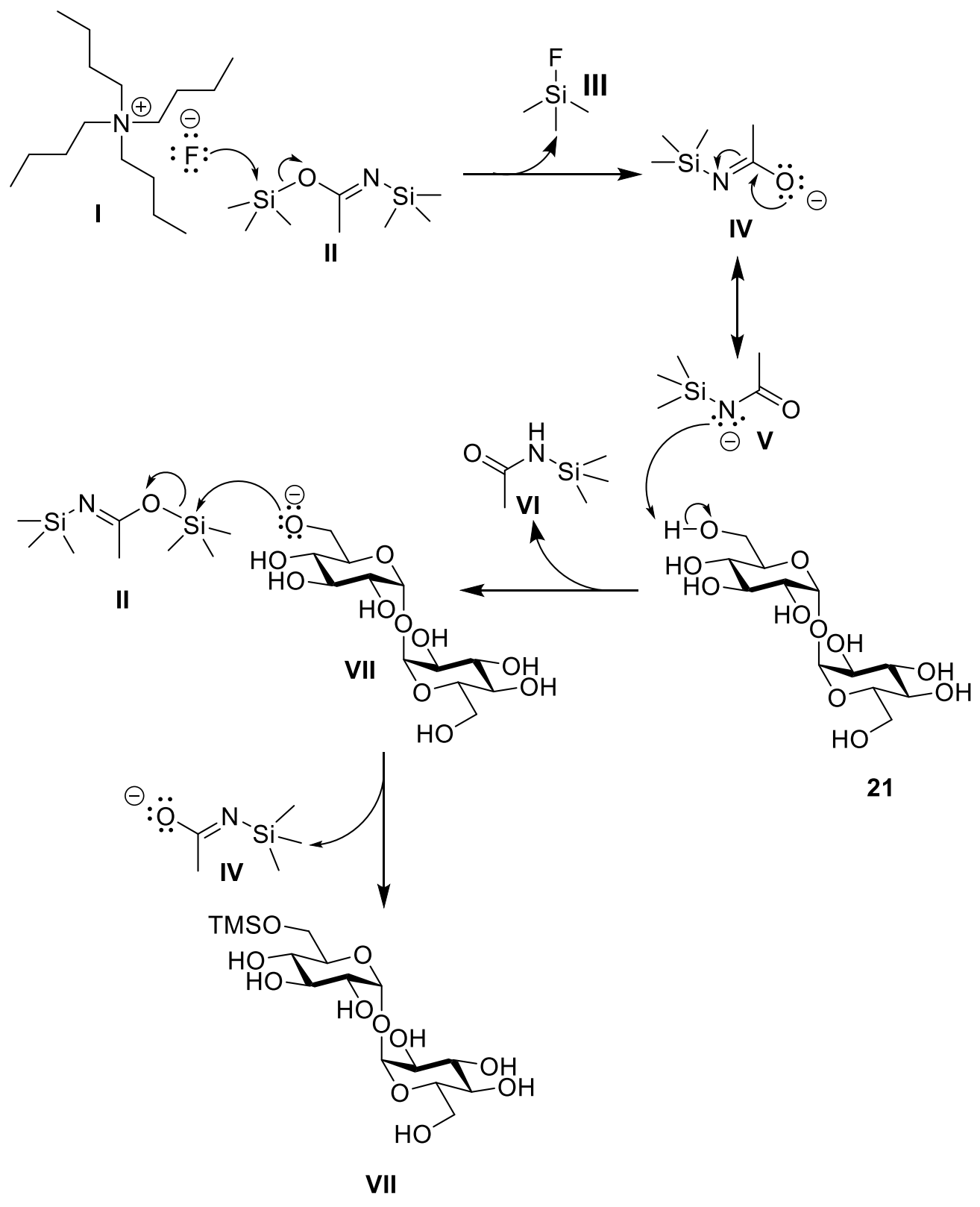

21

Scheme 7. Mechanism of the silylation of trehalose

Subjecting $\alpha, \alpha^{\prime}$-trehalose to the silylation reaction conditions gave hexa-silylated trehalose $\mathbf{2 5}$ in good (76\%) yield (Scheme 8). Then, in an $N$-ethyl- $N^{\prime}$-(3-dimethylaminopropyl)carbodiimide (EDCI) and 4dimethylaminopyridine (DMAP) mediated esterification reaction, carboxylic acids 26a-d and hexasilylated trehalose 25 were coupled to form diesters 27a-d in good (64-99\%) yields. The TMS-groups were then removed via the agency of Dowex $-\mathrm{H}^{+}$resins, to give the desired TGLs 24a-d in yields of 16-88\%. The saturated lipid derivatives $\mathbf{2 4 a - b}$ have been previously synthesised using the synthetic 
strategy described above with the compounds subsequently being assessed for their ability to activate macrophages to produce cytokines. ${ }^{49}, 68$ The unsaturated derivatives $\mathbf{2 4 c - d}$ have been previously chemically or enzymatically synthesised, ${ }^{97}, 111-113$ however their Mincle agonist activity has not been assessed.

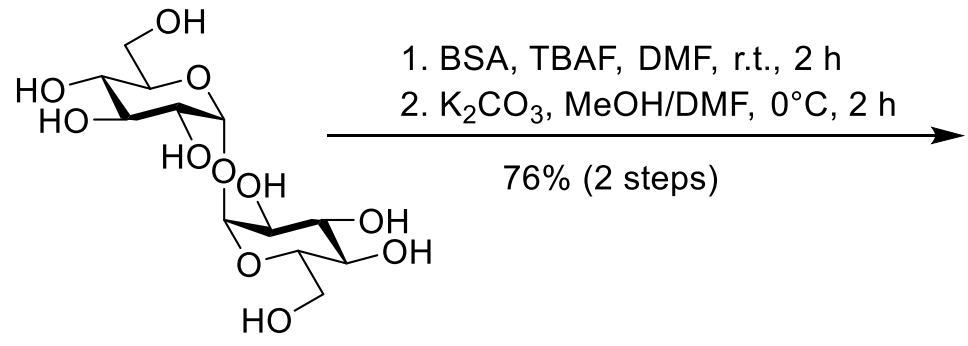

21

$$
\begin{aligned}
& R=s^{s}+Y_{n} \\
& \text { a } n=2 ; \mathbf{b} n=16 \\
& c \mathrm{R}=\mathrm{s}^{\mathrm{s}}+\mathrm{T}_{7}=\mathrm{Y}_{7} \\
& \mathrm{~d} R=\mathrm{s}^{\mathrm{s}}+\mathrm{T}_{7}=\mathrm{Y}_{4}
\end{aligned}
$$

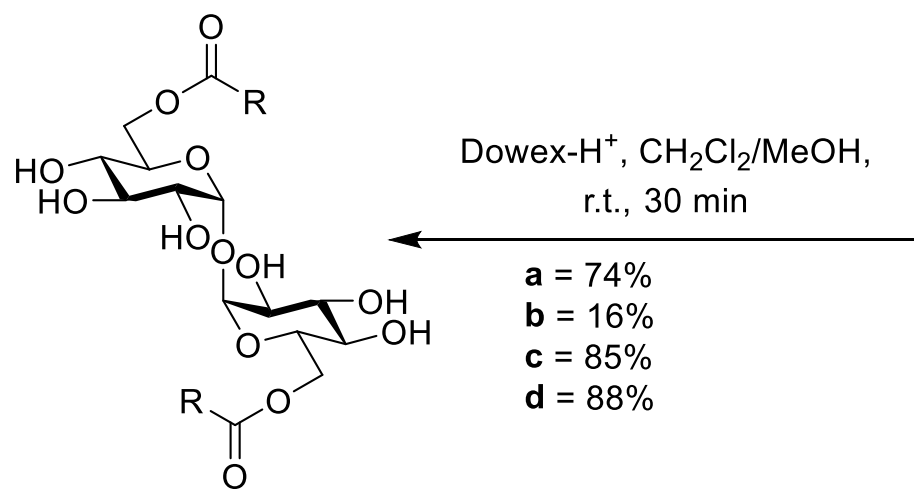

24a-d

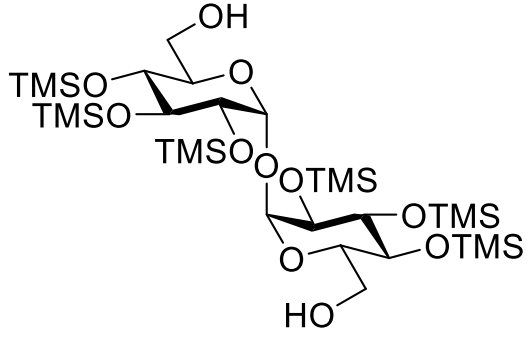

25
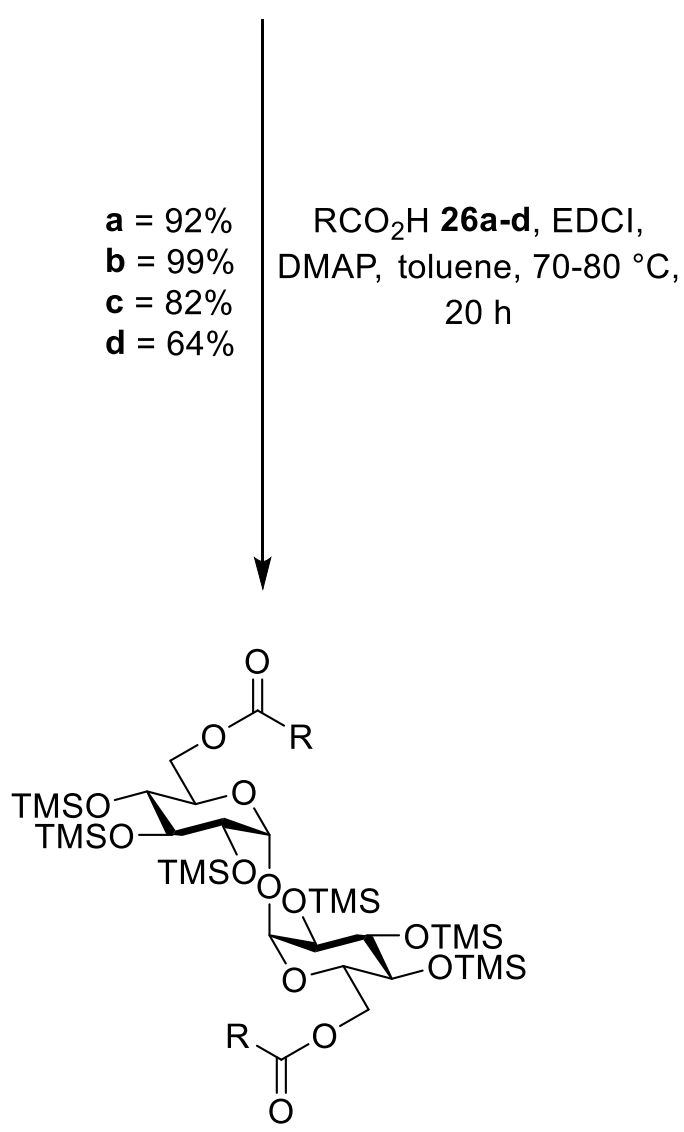

27a-d

Scheme 8. Synthesis of trehalose diester glycolipids 24a-e 
Comparison of the ${ }^{1} \mathrm{H}-\mathrm{NMR}$ spectra of the trehalose diesters and their amide counterparts revealed many similarities but also some differences. For example, in the ${ }^{1} \mathrm{H}-\mathrm{NMR}$ spectrum of the skipped diene derivative 24d (Figure 15) a single anomeric resonance (H-1, $\delta 5.91 \mathrm{ppm})$, indicated the product is a symmetrical diester. The alkene protons of the skipped diene are observed as a multiplet at $\delta$ 5.55$5.46 \mathrm{ppm}$, integrating for four protons. This resonance has a strong correlation in the correlated spectroscopy (COSY) to a distinctive triplet at $\delta 2.93 \mathrm{ppm}$, which is the resonance of the methylene (H-17) between the two alkenes, providing clear evidence of the skipped diene functionality. Comparison to the di-amide analogue 1e similarly shows a single anomeric resonance at $\delta 5.75 \mathrm{ppm}$ which corresponds to a symmetrical di-amide. Another parallel is the skipped diene resonances; the alkene protons of 1e are observed as a multiplet at $\delta 5.54-5.43 \mathrm{ppm}$ and the methylene between the alkenes as a triplet at $\delta 2.91 \mathrm{ppm}$. However, there is a broad triplet at $\delta 8.65$ in the spectra of $\mathbf{1 e}$, which is not observed in the ${ }^{1} \mathrm{H}-\mathrm{NMR}$ of di-ester 24d. This broad triplet corresponds to the NH proton of the amide bond. Another difference between 1e and $\mathbf{2 4 d}$ is the considerable difference in chemical shift of the 6- and 6'-protons. The resonances of the 6- and 6'-protons in di-ester $\mathbf{2 4 d}$ occur at a higher chemical shift ( $\delta 5.01$ and $4.85 \mathrm{ppm})$ than those in di-amide $1 \mathrm{e}(\delta 4.29-4.20$ and $4.01-3.93 \mathrm{ppm})$. This is due to oxygen being more electronegative than nitrogen, making the 6- and 6'-protons more deshielded in 24d than those of 1e. Similarly, H-4 ( $\delta 4.77 \mathrm{ppm})$ is further downfield than H-3 $(\delta 4.20$ ppm) for the ester derivative 24d, while H-3 ( $\delta 4.68)$ is further downfield than H-4 ( $\delta 3.97$ ppm) for the amide derivative $1 \mathbf{e}$. 

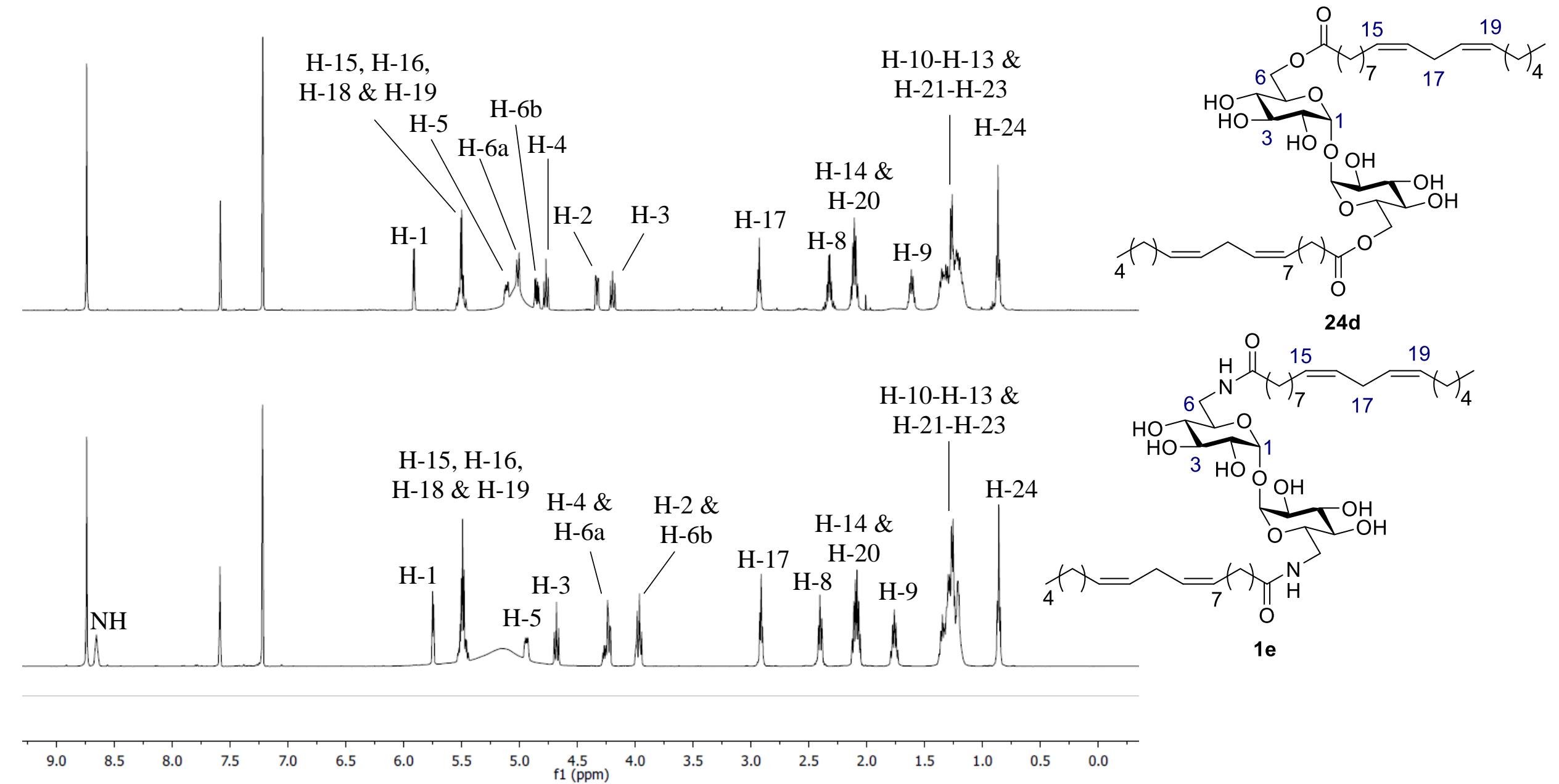

Figure 15. Comparison of the ${ }^{1} \mathrm{H}-\mathrm{NMR}\left(500 \mathrm{MHz}, \mathrm{C}_{5} \mathrm{D}_{5} \mathrm{~N}\right)$ spectra of trehalose diester glycolipid 24d (top) and trehalose amide glycolipid (1e) bottom 


\subsection{Biological Evaluation}

With the target trehalose di-amides 1a-e and diesters 24a-d synthesised, the Mincle agonist activities of these glycolipids, along with that of TDB (5) were then evaluated. Initial biological evaluation was performed using the Mincle NFAT-GFP reporter cell assay. ${ }^{60,62}$ The premise of the assay is that these cells produce transcription factor NFAT upon ITAM-mediated signaling, ${ }^{114}$ which occurs when activated Mincle binds the ITAM of FcR $\gamma .{ }^{62}$ NFAT-GFP cells are transfected with a fusion DNA sequence of the NFAT binding site and a GFP gene, which results in transfected cells producing GFP when ITAM-mediated signaling occurs. ${ }^{62,114}$ Specifically, a NFAT-GFP reporter cell line expressing Mincle and FcR $\gamma$ has been generated. ${ }^{62}$ Mincle activation of a NFAT-GFP reporter cell causes ITAM mediated signaling which leads to the presence of active NFAT in the cell nucleus (Figure 16). NFAT then binds to the transfected NFAT binding site, resulting in the transcription and translation of the

GFP gene. ${ }^{62,114}$ The activated reporter cell becomes GFP positive (Figure 16), and the percentage of GFP positive cells is determined by flow cytometry. ${ }^{60}$ 


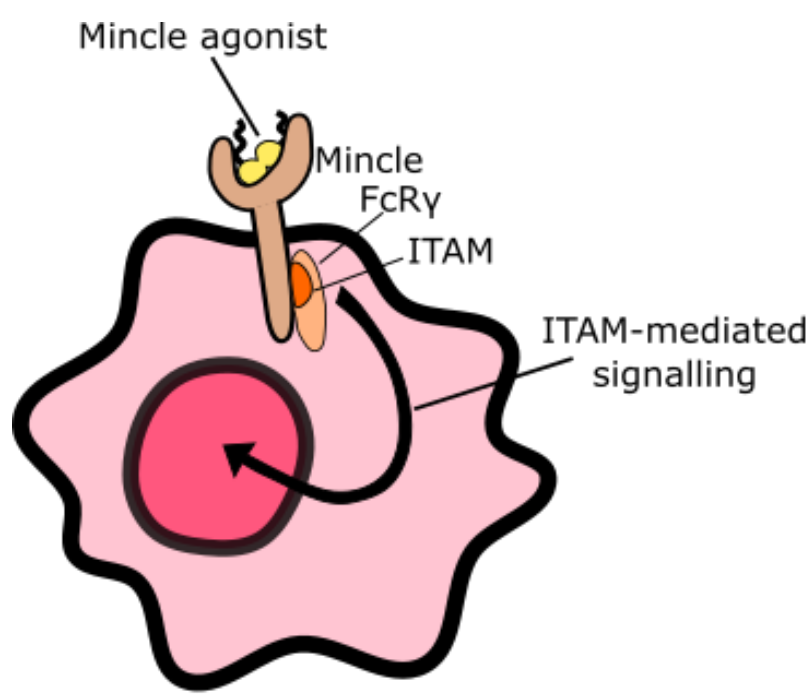

Reporter Cell
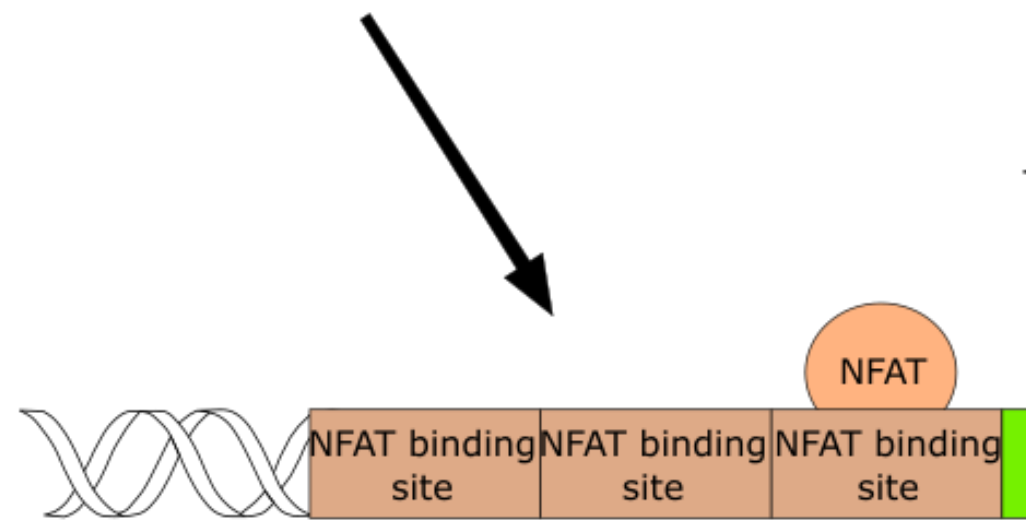

Transfected DNA

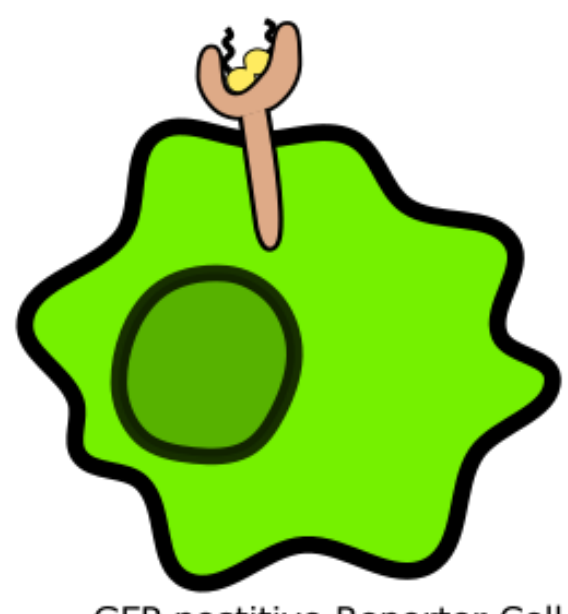

GFP postitive Reporter Cell

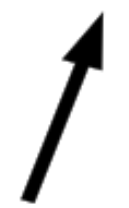

Transcription of GFP gene

Figure 16. NFAT-GFP reporter cells: Binding of an agonist to Mincle results in binding of the ITAM of FcR $\gamma$, which initiates ITAM-mediated signaling which causes active NFAT to be present in the reporter cell nucleus. NFAT binds to the NFAT binding site of the transfected DNA and promotes transcription of the GFP gene. This ultimately results in the reporter cell becoming GFP positive (green), which can be detected by flow cytometry, thus allowing for quantification of Mincle binding and cell activation.

The NFAT-GFP reporter cell assay is a good initial screen for detecting Mincle agonists. As the reporter cells only become GFP positive when the ligand both binds Mincle and causes signal transduction, it provides a good prediction of whether the ligand will activate macrophages to produce cytokines. Indeed, the NFAT-GFP reporter cell has previously been used to screen a variety of potential Mincle ligands. ${ }^{92,115-116}$ 
To determine whether the trehalose amide glycolipids 1a-e could cause similar Mincle-mediated cellular activation as their ester counterparts 24a-d and TDB 5, NFAT-GFP reporter cells expressing either mMincle or hMincle (gifted by S. Yamasaki, Osaka University, Japan) were stimulated with with 1a-e, 24a-d and TDB (5). Activation of the reporter cells was measured by GFP production, as monitored by flow cytometry. Reporter cells expressing only $\mathrm{FcR} \gamma$, and not Mincle, were used as negative controls because any activation of these cells would not be Mincle-dependent (Figure 17). These experiments were performed by A. J. Foster (Victoria University of Wellington, New Zealand). 

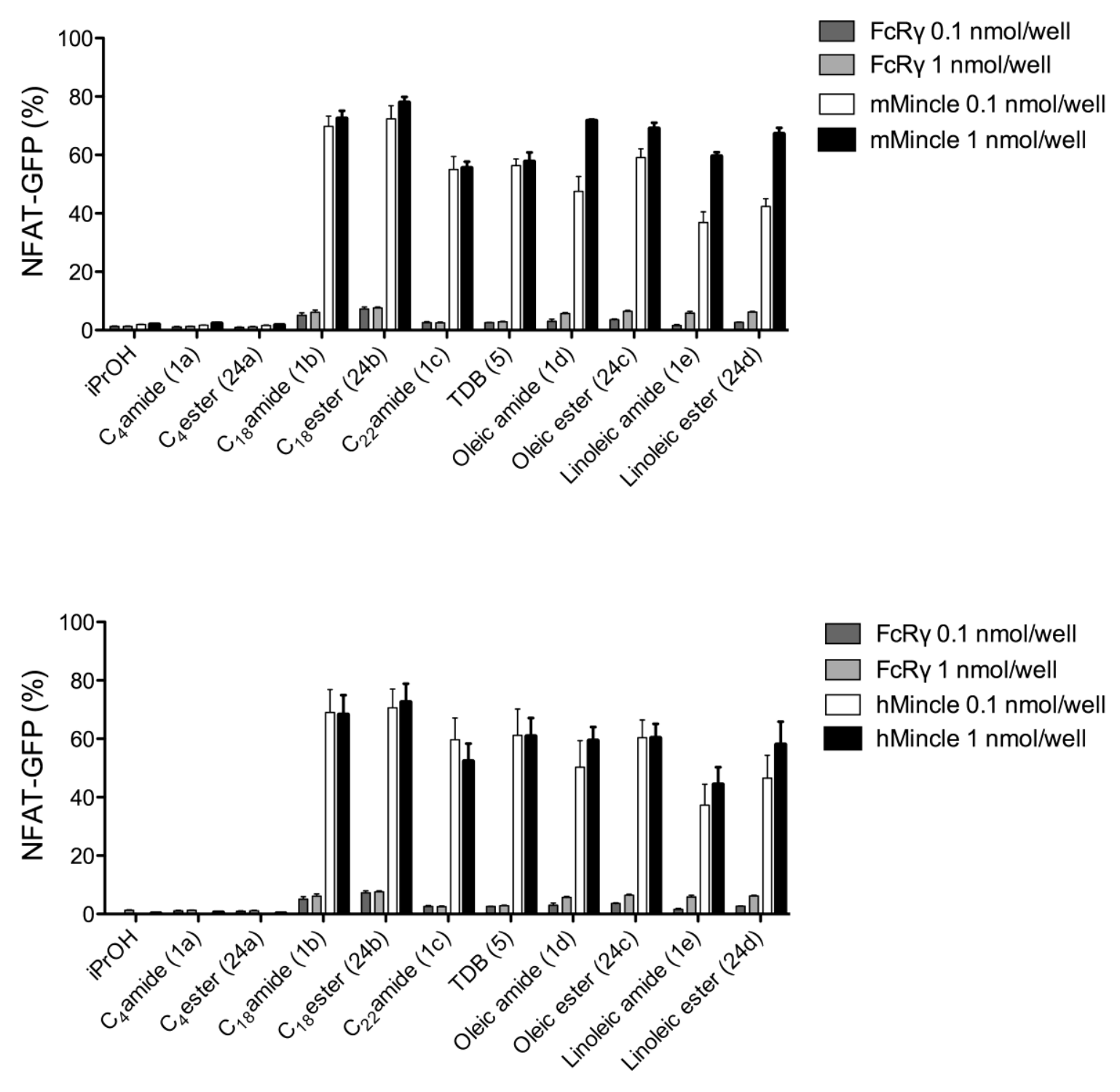

Figure 17. Trehalose amide glycolipids bind and signal through mMincle and hMincle with comparable activity to their ester counterparts. NFAT-GFP 2B4-reporter cells expressing (a) mMincle and $\mathrm{FcR} \gamma$ or (b) hMincle and $\mathrm{FcR} \gamma$ were stimulated using ligand-coated plates $(0.1 \mathrm{or} 1 \mathrm{nmol} / \mathrm{well})$ for 18 hours. The reporter cells were harvested and examined by flow cytometry for GFP expression. Data represents the mean of two independent experiments performed in duplicate (mean \pm SEM). NFATGFP 2B4-reporter cells gifted by S. Yamasaki (Osaka University, Japan), experiments performed by A. J. Foster (Victoria University of Wellington, New Zealand).

As illustrated the cellular activation of Mincle NFAT-GFP reporter cells by di-esters and di-amides with identical lipids was very similar for both mMincle and hMincle. Thus, substitution of an ester 
linkage to an amide linkage in trehalose glycolipids appears to have very little impact on the ability of the compounds to bind and signal through Mincle. The length of the lipid was an important feature which affected NFAT-GFP cell activation. Neither the C4-ester 24a or the C4-amide 1a resulted in activation of the reporter cells, an observation which aligns with previous studies concerning the Mincle-mediated activity of trehalose di-esters. ${ }^{49}, 68$ This finding is likely due to the $\mathrm{C} 4$ lipid chain being of insufficient length to bind the hydrophobic groove of Mincle. ${ }^{65-66,117}$ The C18 and C20 diesters and di-amides all caused NFAT-GFP cell activation, which is consistent with other studies exploring the activity of trehalose di-ester lipid length whereby lipid length of $\geq \mathrm{C} 12$ lead to a Minclemediated immune response. ${ }^{49,68,92}$

Regarding the unsaturation of the lipid chain, this also influenced the activation of the NFAT-GFP reporter cells. While the single alkene of the oleic amide $\mathbf{1 d}$ and ester $\mathbf{2 4 c}$ had similar activities to the C18 amides and esters, the linoleic amide 1e and ester $\mathbf{2 4 d}$ showed a somewhat reduced ability to activate the reporter cells, particularly at lower concentrations of the glycolipid. This suggests that restraining the conformation of the lipid may adversely affect Mincle binding and activation. Notwithstanding, the studies reported herein provide the first examples of trehalose amide glycolipids acting as Mincle agonists.

Taken as a whole, trehalose amides appear to bind and activate both mMincle and hMincle with comparable efficacy to their diester counterparts. The enhanced stability of amide bonds compared to esters bonds under physiological conditions, ${ }^{85-86}$ however may translate to improved in vivo adjuvant activity of the di-amides. Further experiments would be required to assess this hypothesis.

\subsection{Conclusion}

In this work, a short 4 step synthetic route to trehalose amide glycolipids 1a-e with excellent (52-61\%) overall yields was developed. The long chain trehalose amide glycolipids $\mathbf{1 b}$-e were found to be mMincle and hMincle agonists, as determined through use of the NFAT-GFP reporter cell assays. This is the first example of trehalose amide glycolipids as a new class of Mincle agonist. With this knowledge, further biological evaluation of trehalose amide glycolipids 1a-e will be carried out (outside the scope of this thesis) and a second generation of trehalose amide glycolipid ligands will be synthesised and subsequently screened for their ability to activate mMincle and hMincle. 


\section{Lipidated amide brartemicin analogues}

\subsection{Introduction}

The second generation of trehalose amide glycolipids to be investigated are based on the natural product brartemicin. Brartemicin 13 (Figure 18) was isolated from Actinomycete Nonomuraea species and found to inhibit tumour cell invasion. ${ }^{76}$ Due to the structural similarities between brartemicin 13 and TDM (4), Jacobsen et al. used competition binding assays to investigate the potential of brartemicin as a Mincle ligand, and determined that brartemicin $\left(K_{I}=5.5 \pm 0.9 \mu \mathrm{M}\right)$ had a stronger affinity for bovine Mincle (bMincle) than trehalose $\left(K_{I}=1620 \pm 70 \mu \mathrm{M}\right) .{ }^{77}$ Subsequent computational docking studies indicated that brartemicin bound to bMincle with one aromatic ester in the hydrophobic groove, while the other aromatic ring was in close vicinity to Arg183, and therefore potentially involved in $\pi$-cation interactions. ${ }^{77}$ More recently, however, Foster et al. determined that brartemicin and related derivatives were unable to bind to mMincle in ELISA-based Ig-fusion assays. ${ }^{92}$ The discrepancy between these results could be due to differences between the binding site of bMincle to mMincle or could result from differences between competition assays and more direct measurements of binding such as ELISA-based Ig-fusion assays. Notwithstanding, Foster et al. determined that brartemicin and related derivatives did not activate Mincle, as determined using NFAT-GFP reporter cell assays and by assessing cytokine production by BMMs stimulated with the ligands. ${ }^{92}$ 


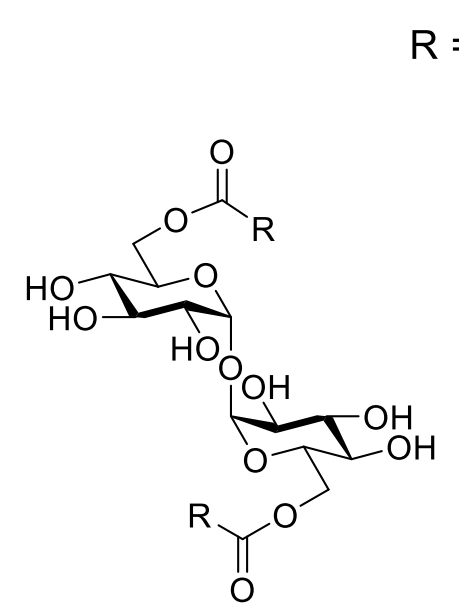

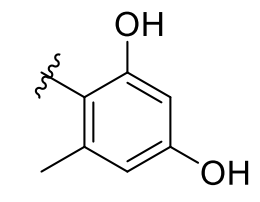

Brartemicin (13)<smiles>[R]#[W]C(C)(C)COc1ccc(C(C)(C)C)cc1</smiles>

28a

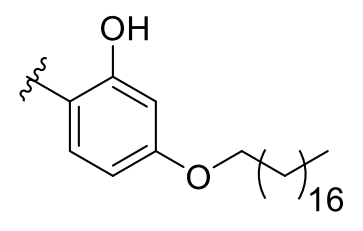

$28 b$

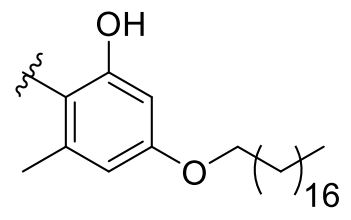

28c

Figure 18. Brartemicin 13 and lipidated brartemicin analogues 28a-c

In contrast to brartemicin and related derivatives, however, lipidated brartemicin derivatives were potent Mincle agonists. ${ }^{92}$ By incorporating lipophilic groups on the brartemicin scaffold, it was postulated that the lipidated brartemicin analogues would be better able to bind to the hydrophobic groove of Mincle while also maintaining the previously mentioned $\pi$-cation interaction. Indeed, the lipidated brartemicin analogues 28a-c (Figure 18), which contained C18 alkyl groups, were strong Mincle agonists, as determined using mMincle and hMincle NFAT-GFP reporter cell assays and by assessing cytokine production by BMMs stimulated with the ligands. Herein, it was also observed that Mincle binding does not directly correlate to a functional immune response, with brartemicin derivatives containing shorter (C7) alkyl groups showing stronger binding to mMincle but weaker agonist activity compared to the $\mathrm{C} 18$ analogues. The reason for the absence of a direct correlation is unclear, although it is possible that Mincle underdoes a conformational change upon ligand binding and this might alter Mincle's activation state and Mincle-ligand affinity. Using the lead Mincle agoinst, 28b, it was determined that Mincle agonist activity was dependent on Arg183 as NFAT-GFP hMincle mutants, where Arg183 was replaced by alanine, failed to produce GFP upon stimulation with the lead compound 28b. This result supports the proposed $\pi$-cation interaction between $\operatorname{Arg} 183$ and the aromatic ring, and that utilising this interaction may improve Mincle binding and activation. Moreover, in vivo vaccination models showed that lipidated brartemicin analogue $\mathbf{2 8 b}$ generated a Th1 recall 
response that was greater than TDB (5), which is considered one of the leading Mincle agonists to date. $^{92}$

As lipidated brartemicin analogues are potent Th1 vaccine adjuvants, it was then postulated that the analogous trehalose amide glycolipids may have even more potent adjuvant activity. Accordingly, lipidated amide brartemicin analogues 2a-c were proposed as synthetic targets (Scheme 9). Here, it was envisioned that 2a-c could be synthesised via the coupling of di-amine $\mathbf{1 9}$ to the appropriately functionalised carboxylic acid 29a-c. Di-amine 19 could be synthesised from $\alpha, \alpha^{\prime}$-trehalose 21, as described in the previous chapter, while the carboxylic acids 29a-c could be prepared from the benzoates 30a-c by alkylation followed by hydrolysis, as developed by Foster et al. ${ }^{92}$ Carboxylic acid 29a was available in the Stocker-Timmer laboratory (synthesised by C. Braganza, Victoria University of Wellington), however acids 29b-c and thus proposed to be synthesised from the esters 30b-c. Herein, it should be noted that an alternative synthesis of amide derivatives of brartemicin has been reported, however this route protects the secondary hydroxyls of trehalose with benzoyl groups and consequently requires six synthetic steps and results in overall yields of $12-20 \% .^{90}$ 
<smiles>[R]c1cc(OCC(C)C)cc([R])c1C(=O)NCC(O)C(O)C(O)C(O)C(O)C(O)C(O)CNC(=O)c1c([R])cc(OCC(C)C)cc1[R]</smiles>

$$
\begin{aligned}
& \text { 2a } R^{1}=R^{2}=H \\
& \text { 2b } R^{1}=O H, R^{2}=H \\
& \text { 2c } R^{1}=O H, R^{2}=M e
\end{aligned}
$$

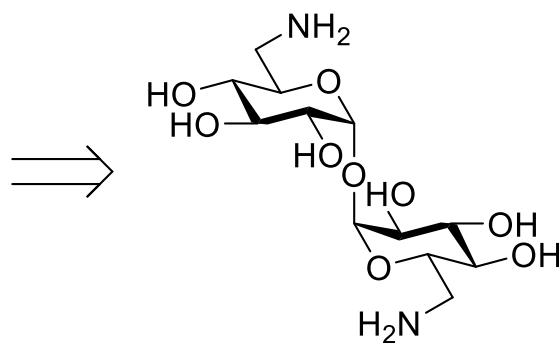

19<smiles>C=CC</smiles>

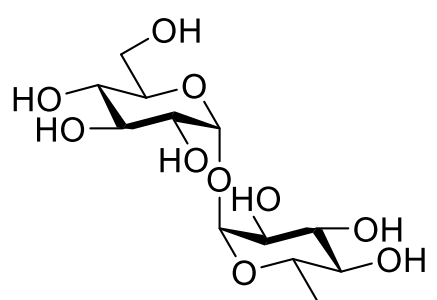

$\mathrm{HO}^{\prime}$

21<smiles>[R]c1cc(OCC(C)([18F])[18F])cc([R])c1C(=O)O</smiles>

29a $R^{1}=R^{2}=H$ 29b $\mathrm{R}^{1}=\mathrm{OH}, \mathrm{R}^{2}=\mathrm{H}$ 29c $R^{1}=O H, R^{2}=M e$<smiles>C=CC</smiles><smiles>[R]OC(=O)c1c([R])cc(O)cc1[R]</smiles>
30a $R^{1}=R^{2}=H, R^{3}=M e$ 30b $R^{1}=\mathrm{OH}, \mathrm{R}^{2}=\mathrm{H}, \mathrm{R}^{3}=\mathrm{Me}$ 30c $R^{1}=\mathrm{OH}, \mathrm{R}^{2}=\mathrm{Me}, \mathrm{R}^{3}=\mathrm{Et}$

Scheme 9. Retrosynthesis of lipidated amide brartemicin analogues 2a-c

\subsection{Results and discussion}

With lipid 29a at hand, synthesis of the first amide brartemicin analogue $\mathbf{2 a}$ was attempted. To this end, di-azide $\mathbf{2 3}$ was subjected to a Staudinger reduction followed by HBTU-mediated coupling to carboxylic acid 29a (Scheme 10). This yielded the desired lipidated amide brartemicin 2a in a good (57\%) yield over 2 steps, which is comparable to the yields obtained for the synthesis of the ester derivatives 28a-c, although in the latter esterification, protected trehalose derivative $\left(2,2^{\prime}, 3,3^{\prime}, 4,4^{\prime}\right.$ hexa- $O$-benzyl- $\alpha, \alpha^{\prime}$-trehalose) was required. ${ }^{92}$ To assist with the characterisation of the di-amide $\mathbf{2 a}$, HRMS and NMR spectroscopy was undertaken. Evidence that two lipids had been symmetrically installed onto the trehalose cores was obtained by HRMS $\left(m / z\right.$ calcd. for $\left[\mathrm{C}_{26} \mathrm{H}_{104} \mathrm{~N}_{2} \mathrm{O}_{13}+\mathrm{H}\right]^{+}$: 1085.7611, obsd. 1085.7609] and in there being only one resonance for the anomeric centres of 2a in 
the ${ }^{1} \mathrm{H}-\mathrm{NMR}$ spectrum. HMBC spectroscopy was used to confirm that the lipids had been coupled to the correct positions. Here, the carbonyl peak $(\delta 169.0)$ correlated to H-6a $(\delta 4.43)$ and H-6b $(\delta 4.14)$ of the modified trehalose core, the proton of the amide group $(\delta 9.02)$, and one of the aromatic protons ( $\delta 8.33)$ (Figure 19).

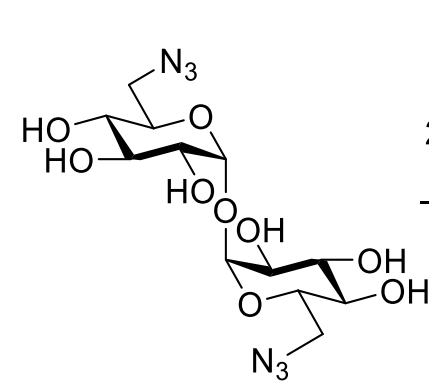

23
1. $\mathrm{PMe}_{3}, \mathrm{H}_{2} \mathrm{O}$, DMF

$0^{\circ} \mathrm{C} \rightarrow$ r.t., $20 \mathrm{~h}$

2. 29a, HBTU, DIPEA, pyridine r.t., $20 \mathrm{~h}$ $57 \%$ (2 steps)

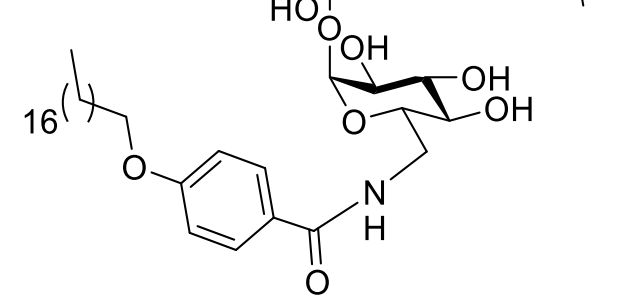

$2 a$

Scheme 10. Synthesis of lipidated amide brartemicin analogue 2a. 


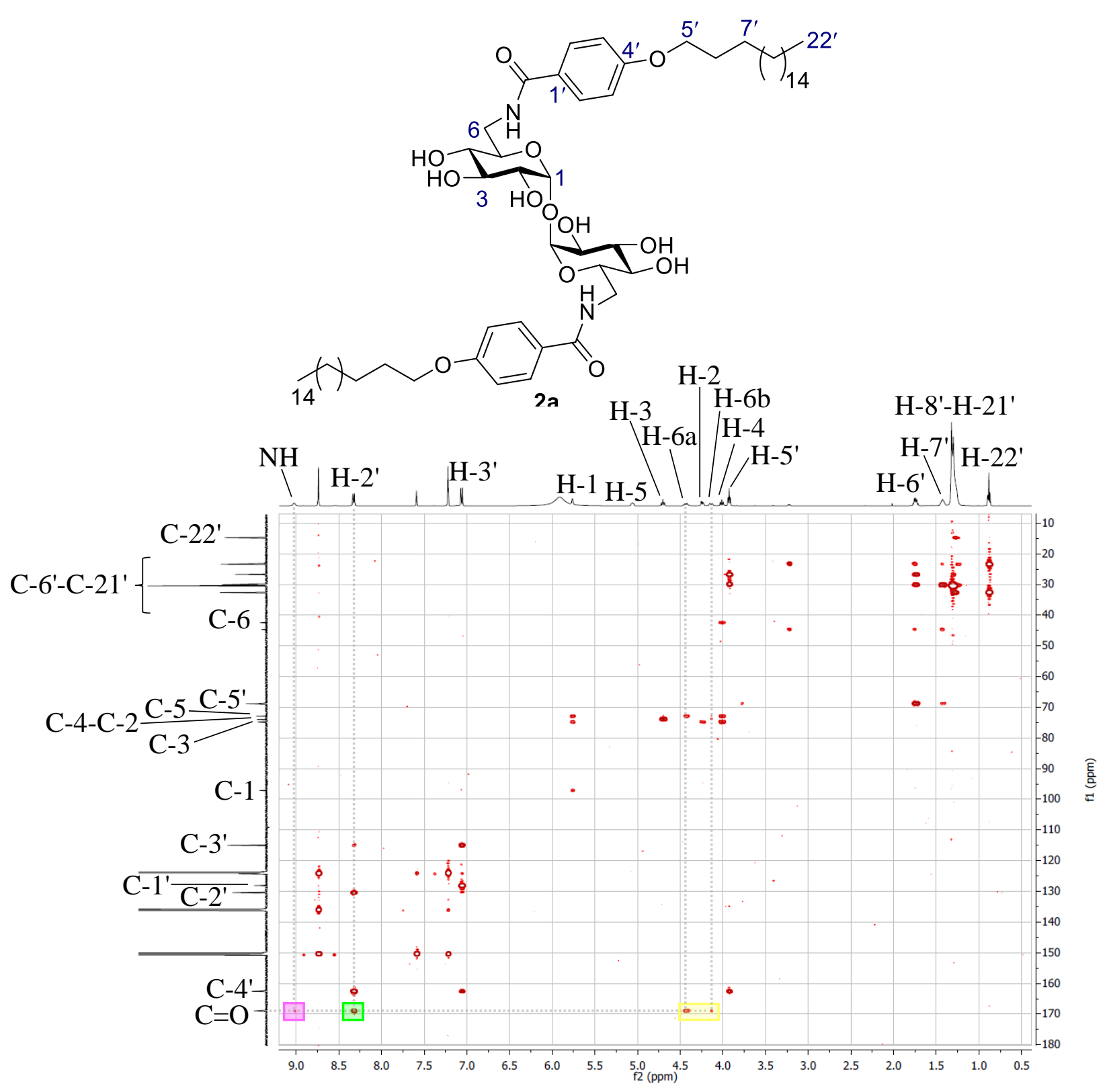

Figure 19. HMBC of lipidated brartemicin amide 2a.

To synthesise the second lipidated amide brartemicin analogue $\mathbf{2 b}$, carboxylic acid $\mathbf{2 9} \mathbf{b}$ first needed to be prepared. To this end, 2,4-dihydroxy benzoic acid $\mathbf{3 1}$ was reacted with thionyl chloride in the presence of methanol to give 2,4-dihydroxybenzoyl chloride which reacts with methanol forming methyl ester 30b in a good (66\%) yield (Scheme 11). The benzoate 30b was then alkylated with 1bromooctadecane to give the alkylated ester $\mathbf{3 2}$ in excellent (93\%) yield. Finally, the ester $\mathbf{3 2}$ was hydrolysed under basic conditions to give the desired carboxylic acid $\mathbf{2 9 b}$, once again in excellent $(96 \%)$ yield. ${ }^{92}$ 


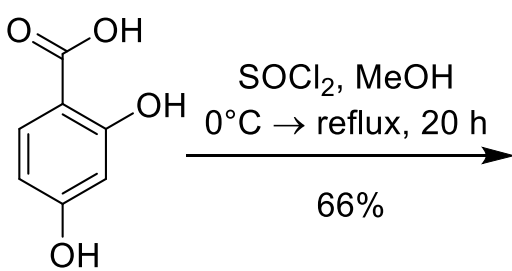

31

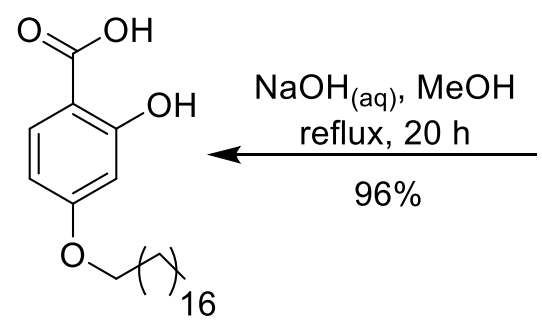

29b<smiles>COC(=O)c1ccc(O)cc1O</smiles>

$30 \mathrm{~b}$

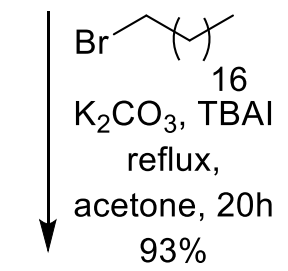<smiles>COC(=O)c1ccc(OCCN(C)C(F)(F)F)cc1O</smiles>

32

Scheme 11. Synthesis of carboxylic acid $\mathbf{2 9 b}$.

Initially it was hoped that protection of the phenol functionality of $\mathbf{2 9 b}$ may not be required, as $\mathbf{2 9 b}$ may selectively couple with the product of the Staudinger reduction of di-azide $\mathbf{2 3}, 6,6$ '-diamino-6,6'dideoxy- $\alpha, \alpha^{\prime}$-trehalose, with minimal esterification between two equivalents of 29b (Scheme 11). Accordingly following the Staudinger reduction of di-azide 23 to yield 6,6'-diamino-6,6'-dideoxy- $\alpha, \alpha^{\prime}$ trehalose, carboxylic acid 29b was added to the crude product and following complete consumption of the starting material, several products were observed via TLC $\left(\mathrm{R}_{f}=0.67,0.61,0.55\right.$ and $0.45,4: 1$ $\left.\mathrm{CH}_{2} \mathrm{Cl}_{2}: \mathrm{MeOH}, v / v\right)$. The products were difficult to separate by silica gel flash chromatography however, one product $\left(\mathrm{R}_{f}=0.45,4: 1 \mathrm{CH}_{2} \mathrm{Cl}_{2}: \mathrm{MeOH}, v / v\right)$ was isolated with sufficient purity and yield (21\%) to allow for tentative characterisation by ${ }^{1} \mathrm{H}-\mathrm{NMR}$ spectrum. Here, the product had a single anomeric resonance $(\delta 5.78)$, a single broad triplet $(\delta 9.31)$ characteristic of the $\mathrm{NH}$ of the amide bond and three aromatic resonances $(\delta, 8.39,6.83 \& 6.60)$. The integration of the anomeric resonance was in an approximate 1:3 ratio to the methyl of the lipid. This data, and further ${ }^{13} \mathrm{C}-\mathrm{NMR}$ and $2 \mathrm{D}-\mathrm{NMR}$, lead to the conclusion that this product was the target $\mathbf{2 b}$ (Scheme 12). The ${ }^{1} \mathrm{H}-\mathrm{NMR}$ spectra of the other products (isolated as mixtures) also contained resonances indicative of the trehalose core, but 
also multiple $\mathrm{NH}$ resonances and aromatic resonances, and a ratio for the integration of the trehalose anomeric centres to lipid resonances that was suggestive of additional esterification reactions at the phenolic hydroxyl. suggested multiple lipids. Thus, it was hypothesised that products such as 33a and $\mathbf{3 3 b}$ were also being formed along with oligomers of $\mathbf{2 9 b}$. In an attempt to suppress these esterification side-reactions, the reaction was repeated in 2:1 pyridine: $\mathrm{MeOH}(v / v)$, with the notion that methanol would preferentially react with excess carboxylic acid. However, under these conditions no product was observed after $20 \mathrm{~h}$ by TLC under these conditions.
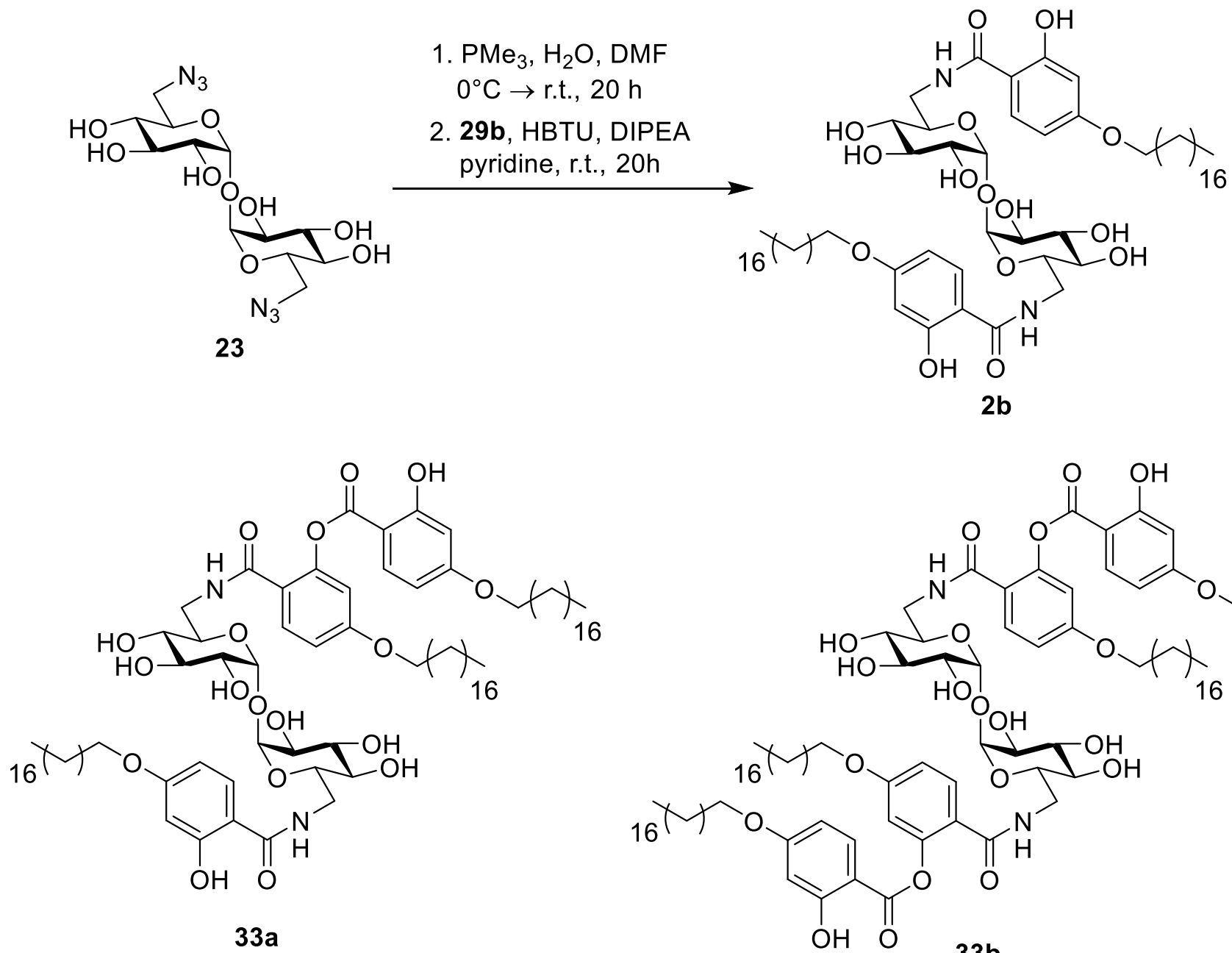

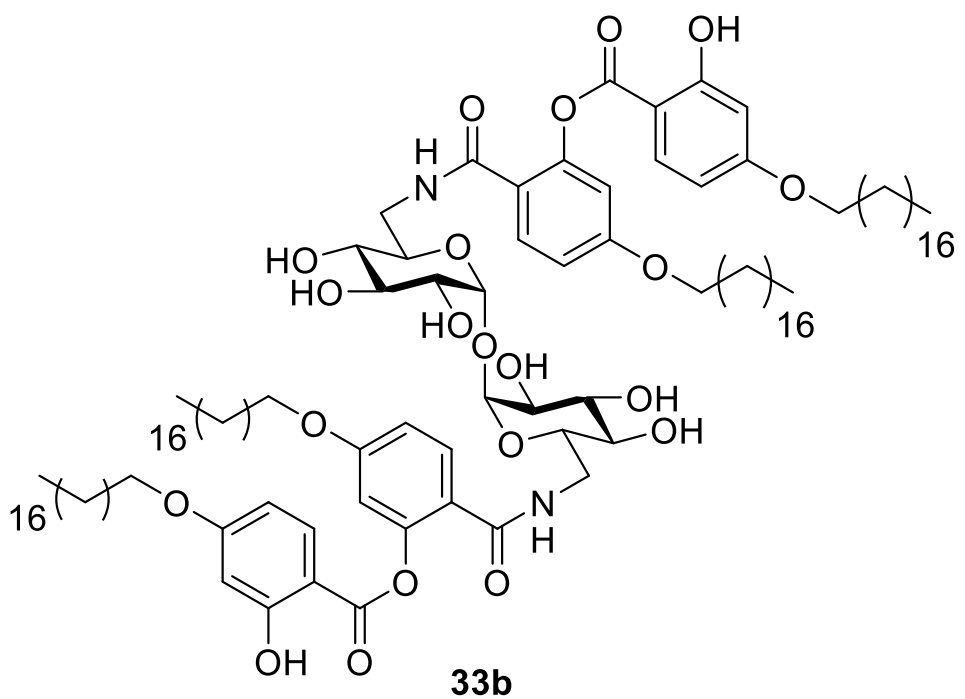

Scheme 12. First synthesis of lipidated amide brartemicin analogue $\mathbf{2 b}$. 
The undesired reactivity of the phenolic hydroxy led to the conclusion that protection of this functional group was required. Accordingly, the methyl ester $\mathbf{3 2}$ was subjected to treatment with benzyl bromide, potassium carbonate and tetrabutylammonium iodide (TBAI) to give the benzylated product $\mathbf{3 4}$ (Scheme 13). ${ }^{92}$ Hydrolysis of ester 34 under basic conditions then gave the desired protected carboxylic acid $\mathbf{3 5}$ in excellent yield.

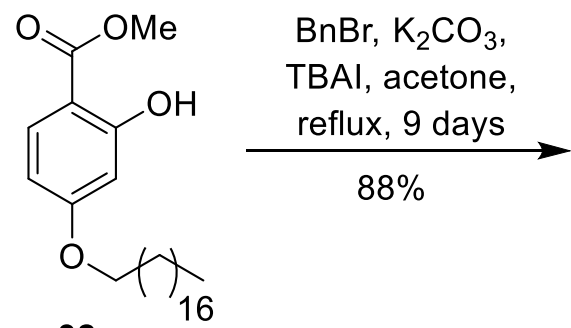

32<smiles>COC(=O)c1ccc(OCCC(C)(C)C)cc1OCc1ccccc1</smiles>

34

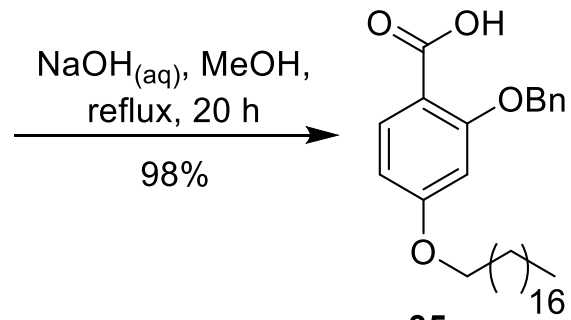

35

Scheme 13. Synthesis of protected carboxylic acid 35.

With carboxylic acid $\mathbf{3 5}$ in hand, the synthesis of $\mathbf{2 b}$ was once again attempted (Scheme 14). The Staudinger reduction of di-azide 23 and the subsequent coupling of 6,6'-diamino-6,6'-dideoxy- $\alpha, \alpha^{\prime}$ trehalose to carboxylic acid $\mathbf{3 5}$ occurred smoothly with a single product being observed by TLC $\left(\mathrm{R}_{f}=\right.$ 0.35 9:1 $\left.\mathrm{CH}_{2} \mathrm{Cl}_{2}: \mathrm{MeOH} v / v\right)$. Following an aqueous work-up, the product was purified by silica gel flash column chromatography to give the desired di-amide 36, in an excellent (93\%) yield. The benzyl protecting groups were then removed via a hydrogenation reaction using $\mathrm{Pd}(\mathrm{OH})_{2}$ as the catalyst to form the desired trehalose amide glycolipid $\mathbf{2 b}$ in $75 \%$ yield. 


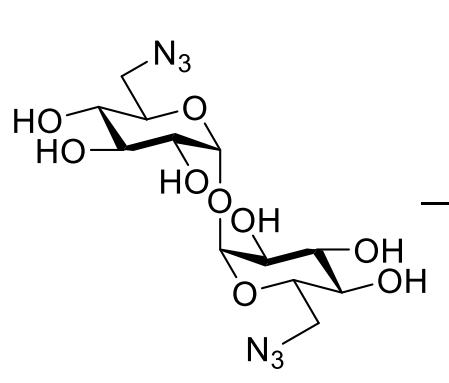

23

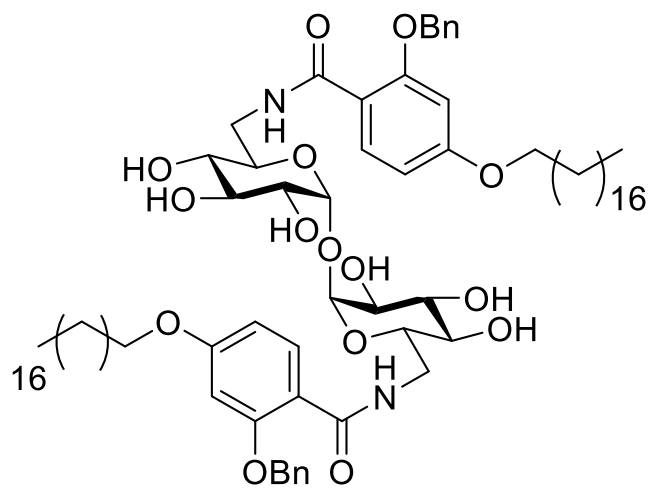

36

$\mathrm{Pd}(\mathrm{OH})_{2} / \mathrm{C}, \mathrm{H}_{2}$ $1: 1 \mathrm{CH}_{2} \mathrm{Cl}_{2}: \mathrm{MeOH}(\mathrm{v} / \mathrm{v})$ r.t., $48 \mathrm{~h}$ $75 \%$<smiles>CC(C)(C)CCOc1ccc(C(=O)NCC(C)(C)C)c(O)c1</smiles>

Scheme 14. Synthesis of lipidated amide brartemicin analogue $\mathbf{2 b}$

Having synthesised $\mathbf{2 b}$ using the benzyl protected hydroxy carboxylic acid $\mathbf{3 5}$, the same synthetic strategy was then used for the synthesis of $\mathbf{2 c}$. To this end, benzoate $37^{118}$ was alkylated to form $\mathbf{3 8}$ in an excellent (91\%) yield (Scheme 15). ${ }^{92}$ The phenolic hydroxyl of alkylated benzoate 38 was then protected by a benzylation reaction forming 39. Finally, the ethyl group of $\mathbf{3 9}$ was hydrolysed under basic conditions, to give the desired carboxylic acid $\mathbf{4 0 .}$ 
<smiles>CCOC(=O)c1c(C)cc(O)cc1O</smiles>

37

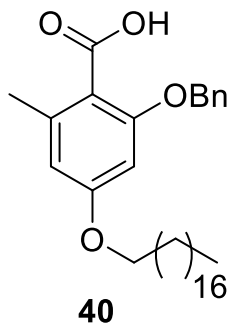

$\mathrm{NaOH}_{(\mathrm{aq})}, \mathrm{EtOH}$,<smiles>[Mg][Mg][Mg]</smiles>

40

Scheme 15. Synthesis of carboxylic acid 40.

Trehalose di-azide $\mathbf{2 3}$ was then subjected to a Staudinger reduction and the resulting product, 6,6'diamino-6,6'-dideoxy- $\alpha, \alpha^{\prime}$-trehalose, used in an HBTU-mediated coupling to $\mathbf{4 0}$ (Scheme 16). This yielded the desired di-amide $\mathbf{4 1}$ in a good (50\%) yield over 2 steps. Di-amide $\mathbf{4 1}$ was then subjected to hydrogenation conditions to give the last of the target lipidated amide brartemicin analogues, $2 \mathbf{c}$, in $53 \%$ yield. 


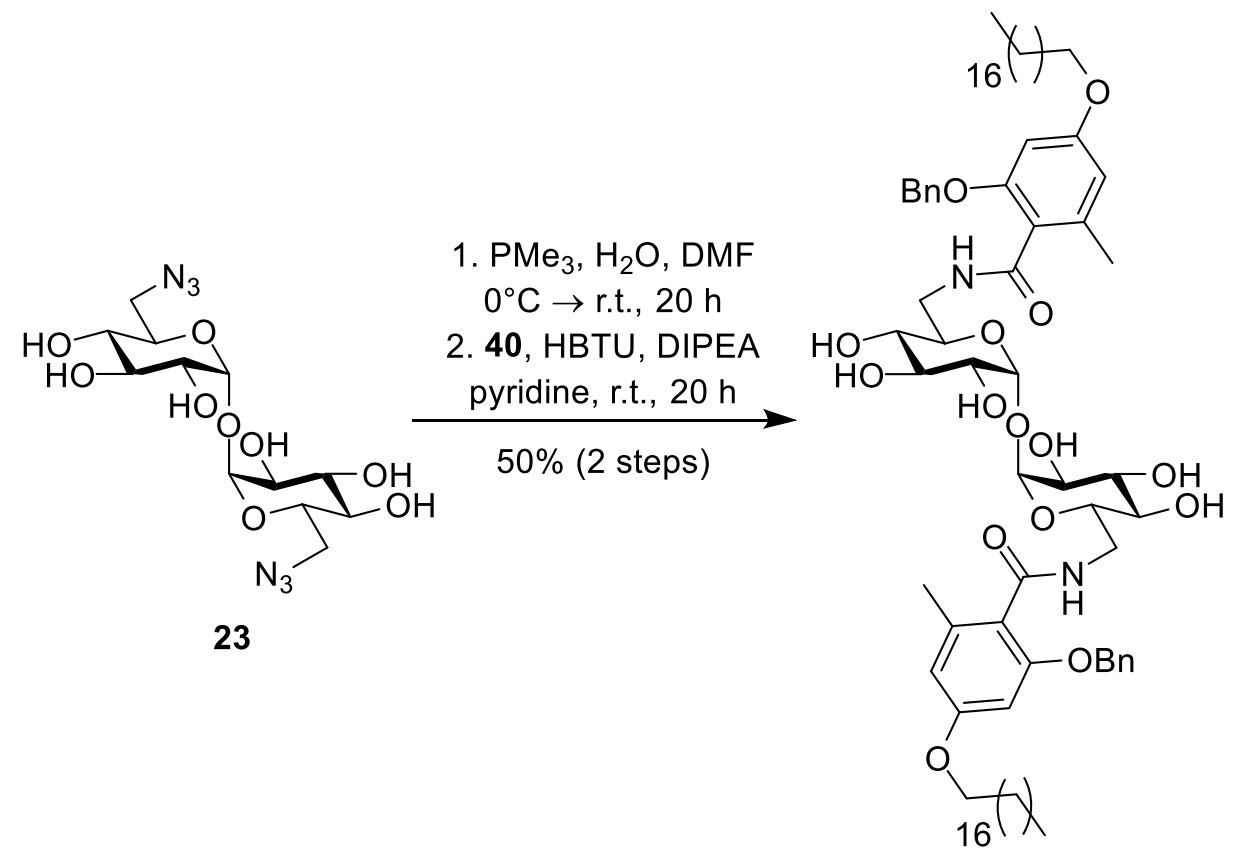

41

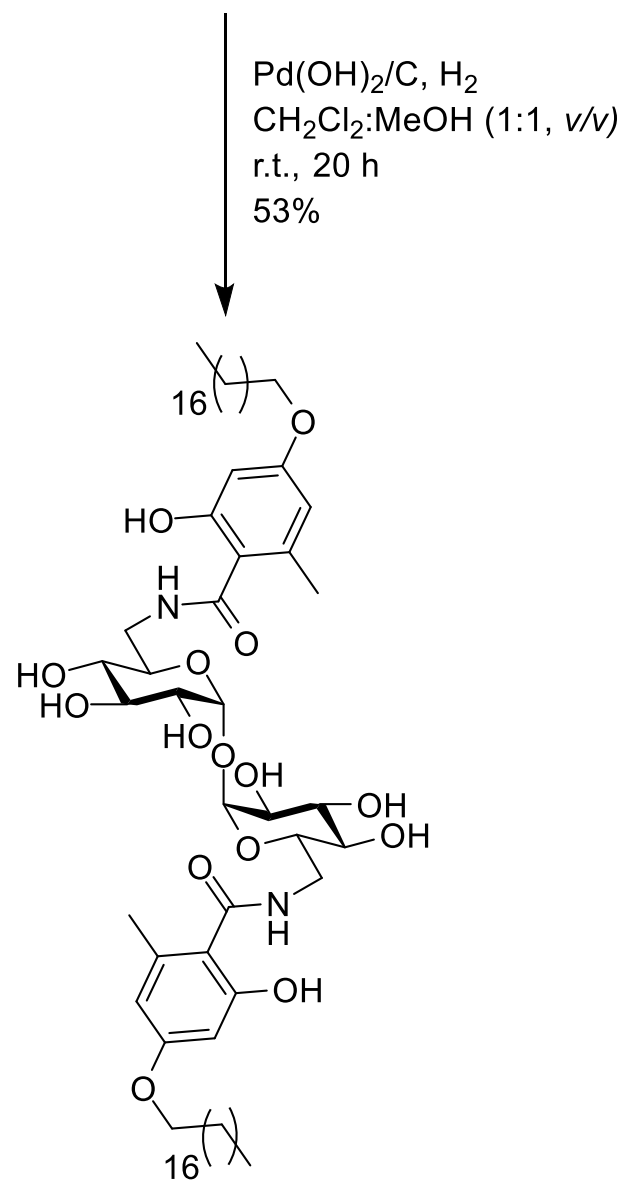

2c

Scheme 16. Synthesis of lipidated amide brartemicin analogue 2c. 


\subsection{Conclusions}

This chapter presented the synthesis of a second generation of trehalose amide glycolipids $\mathbf{2 a - c}$, the structures of which are based on the recently reported potent Mincle agonists, lipidated brartemicin analogues. ${ }^{92}$ These brartemicin analogues contain an aromatic ring adjacent to the amide functional group, with one such aromatic group proposed to have $\pi$-cation interactions with Arg183 of Mincle. While the conjugation of 4-(octadecyloxy)benzoic acid 29a to the in situ generated 6,6'-diamino-6,6'dideoxy- $\alpha, \alpha^{\prime}$-trehalose occurred smoothly under the mediation of HBTU and DIPEA, the presence of a 2-hydroxy group on acids 29b and 29c necessitated the use of benzyl protection of the hydroxyl of acids 35 and $\mathbf{4 0}$ for the synthesis of glycolipids $\mathbf{2 b}$ and $\mathbf{2 c}$. Nonetheless, by using benzyl protecting groups on the phenol hydroxyls, 2a-c could be efficiently synthesised (4-8 steps, 17-38\% overall yield). In the near future the Mincle agonist activity of 2a-c will be studied. As mMincle and hMincle accommodated the aliphatic trehalose amide glycolipids 1a-e, it bodes well that $\mathbf{2 a - c}$ may be potent Mincle agonists. 


\section{Conclusions and future prospects}

In this thesis, the preparation of trehalose amide glycolipids and the identification of these glycolipids as a new class of Mincle agonist was presented. To this end, five straight chain trehalose amide glycolipids 1a-e were prepared in four steps and in excellent (51-63\%) overall yields. Subsequently, 1a-e were found to be agonists of murine and human Mincle, as determined using NFAT-GFP reporter cell assays, with 1a-e having comparable GFP production to their ester counterparts. This is the first report of trehalose amide glycolipids acting as Mincle agonists.

Second generation trehalose amide glycolipids $\mathbf{2 a - c}$, have also been prepared. The lipidated amide brartemicin analogues 2a-c contain aromatic rings, which are postulated to allow for $\pi$-cation interactions with Arg183 of Mincle, and are proposed to be potent Mincle agonists like their ester counterparts. Despite the necessity to protect the phenolic hydroxyls in the synthesis of $\mathbf{2} \mathbf{b}-\mathbf{c}$, the brartemicin analogues 2a-c could be prepared efficiently (4-8 steps, 38-17\% overall yield). In the near future, the Mincle agonist activity of $\mathbf{2 a - c}$ will also be determined using the NFAT-GFP reporter cells.

To further explore the potential of the trehalose amide glycolipids as vaccine adjuvants, the functional immune response to the glycolipids will be determined in due course. Trehalose amide glycolipids are expected to be advantageous due to their enhanced stability and this should ultimately be observed as an improved functional immune response in comparison to their ester counterparts. To assess the functional immune response in vitro, the ability of 1a-e and 2a-c to activate murine bone marrow derived macrophages (BMMs) will be assessed by incubating the glycolipids with BMMs and measuring cytokines [e.g., interleukin-6 (IL-6), IL-1 $\beta$, TNF- $\alpha$ ] production using enzyme-linked immunosorbent assays (ELISAs). The activation of human peripheral blood mononuclear cells (PBMCs) by the ligands will similarly be assessed by cytokine production. Evidence that the trehalose amide glycolipids are more efficacious than their diester counterparts would be indicated by increased levels of inflammatory cytokines, particularly those that are known to promote cellular immune responses. For example, IL-6 promotes the differentiation of naïve T-cells to mature Th17 cells, while IL-4 promotes maturation to Th2 cells. ${ }^{26}$

The ability of trehalose amide glycolipids to invoke a cellular immune response would also be determined by co-culturing APCs and T-cells in the presence of the selected trehalose glycolipid. Upon challenge with antigen, the levels of the cytokines IFN- $\gamma$, which is secreted by Th1 cells, and IL-17, which plays an essential role in cellular immunity would be measured. ${ }^{92}$ Comparison of the levels of 
these cytokines to the levels produced by their ester counterparts will indicate whether the amides have improved efficacy. However, as in vitro results of Mincle agonists do not always directly correlate to in vivo results, ${ }^{50}$ and differences in the metabolism of trehalose glycolipids will be greatest in vivo, the lead trehalose amide glycolipid, as determined from the in vivo experiments described above, would then need to be assessed in an in vivo vaccination model and compared to the equivalent ester counterpart as a point of comparison. A delayed-type hypersensitivity immunisation experiment is one such model that may be used..$^{92}$ Here, mice are immunised with the glycolipid and an antigen, such as OVA, before being subsequently challenged with the antigen again and then sacrificed. By collecting blood and the spleens of the mice, the levels of cytokines produced by T-cells, such as IFN- $\gamma$ and IL17 , can be measured, as well as the levels of antigen-specific antibodies. ${ }^{92}$ If the trehalose amide glycolipid results in a strong immune response, further in vivo assays using an appropriate animal for a particular pathogen can then be undertaken. As trehalose glycolipids have been found to be effective at promoting a Th1 and Th17 immune response, ${ }^{56,92}$ which is particularly important for immunity against bacteria and intracellular pathogens, ${ }^{26}$ bacterial or intracellular pathogens for which there are no existing vaccines, or sub-optimal vaccines, would be good models to use. For example, use of the amide-trehalose adjuvant in vaccination studies against Streptococcus pneumoniae might be particularly relevant. ${ }^{119}$

In summary, this thesis reports on the efficient synthesis of a new class of Mincle agonists, trehalose amide glycolipids. Although further work is required to determine if the more physiologically stable amide linkage leads to more promising adjuvant activity in vivo, the in vitro response as determined using NFAT-GFP reporter assays, indicates that Mincle can accommodate trehalose amide glycolipids as well as their ester counterparts. This bodes well for the potential application of trehalose amide glycolipids as vaccine adjuvants. 


\section{Experimental}

\subsection{General Methods}

Unless otherwise stated, all reactions were carried out under an atmosphere of argon (BOC). Before use methanol (Fisher) was distilled under reduced pressure, ethyl acetate (Pacific Sphere Limited) was distilled under reduced pressure, petroleum ether (Vigor Sphere Pte Limited) was distilled under reduced pressure, acetone (Pacific Sphere Limited) was distilled under reduced pressure, toluene (Schralau) was dried and stored over Na (Aldrich) wire. Distilled dichloromethane was prepared by distilling dichloromethane (Fisher) from $\mathrm{P}_{2} \mathrm{O}_{5}$ (Reidel-de Haën). Distilled pyridine was prepared by distilling pyridine (Carlo Erba) from $\mathrm{NaOH}$ (Pancreac). Dowex- $\mathrm{H}^{+}$(Dowex® 50WX8, 100-200 mesh, Serva) was activated by washing with $1.0 \mathrm{M} \mathrm{HCl}$, water (until filtrate was neutral), and methanol before use. Triphenylphosphine (Acros), $\alpha, \alpha^{\prime}$-D-trehalose (Carbosynth), anhydrous DMF (Acros), $\mathrm{I}_{2}$ (Ajax Chemicals), NaOMe (Chimica), Celite 545 (Roth), dichloromethane (Fisher), sodium azide (Ajax Chemicals), $\mathrm{PMe}_{3}$ (1.0 M in THF, Aldrich), butyric anhydride (Janssen Chimica), pyridine (Carlo Erba), DIPEA (Sigma-Aldrich), HBTU (Apollo Scientific), stearic acid (ICN Pharmaceuticals), ${ }^{t} \mathrm{BuOH}$ (Alfa Aesar), $\mathrm{HCl}$ (Ajax), $\mathrm{NaHCO}_{3}$ (Pure Science), $\mathrm{NaCl}$ (Pure Science), $\mathrm{MgSO}_{4}$ (Pure Science), behenic acid (BDH), oleic acid (BDH), linoleic acid (Sigma), BSA (Acros), TBAF (1.0 M in THF, Acros), isopropanol (Fisher), $\mathrm{K}_{2} \mathrm{CO}_{3}$ (Pancreac), AcOH (Scharlau), EDCI (Chem-Impex), DMAP (Aldrich), 2,4-dihydroxy benzoic acid (BDH), thionyl chloride (Roth), 1-bromooctadecane (Aldrich), TBAI (Reidel-de Haën), NaOH (Pancreac), benzyl bromide (Aldrich), NaOH (Pancreac), ethanol (Fisher) $\mathrm{Pd}(\mathrm{OH})_{2} / \mathrm{C}$ (20 wt\% loading, Aldrich), and $\mathrm{H}_{2}$ gas (BOC) were used as received. Solvents were removed by evaporation under reduced pressure. Reactions were monitored by TLC with Macherey-Nagel silica gel-coated plastic sheets $\left(0.20 \mathrm{~mm}\right.$ with fluorescent indicator $\left.\mathrm{UV}_{254}\right)$ via detection by $\mathrm{UV}$ absorption (254 nm), dipping in a solution of $10 \% \mathrm{H}_{2} \mathrm{SO}_{4}$ in EtOH followed by charring, dipping in an ethanolic solution of ninhydrin followed by heating, or dipping in ceric ammonium molybdate solution followed by heating. Column chromatography was performed using silica gel (40-63 $\mu \mathrm{m}$, Roth) or Dianion ${ }^{\circledR}$ HP-20 (Supelco). HRMS were recorded on an Agilent 6530 Q-TOF mass spectrometer utilising a JetStream electrospray ionization source in positive or negative mode. Optical rotation was recorded on an Autopol II or IV (Rudolph Research Analytical) at $589 \mathrm{~nm}$ (sodium D-line). Infrared (IR) spectra were recorded as thin films using a Bruker Platinum ATR and are reported in wave numbers $\left(\mathrm{cm}^{-1}\right)$. Nuclear magnetic resonance (NMR) spectra were recorded at 20 
${ }^{\circ} \mathrm{C}$ in $\mathrm{D}_{2} \mathrm{O}$ (Apollo Scientific), $\mathrm{CDCl}_{3}$ (Aldrich), $\mathrm{D}_{3} \mathrm{COD}$ (Apollo Scientific) or $\mathrm{C}_{5} \mathrm{D}_{5} \mathrm{~N}$ (Apollo Scientific) using a Varian INOVA operating at 500 or $600 \mathrm{MHz}$. Chemical shifts are given in ppm $(\delta)$ relative to residual solvent peaks. NMR peak assignments were made using correlated spectroscopy (COSY), HSQC and HMBC 2D experiments.

\subsection{Chemical Synthesis}

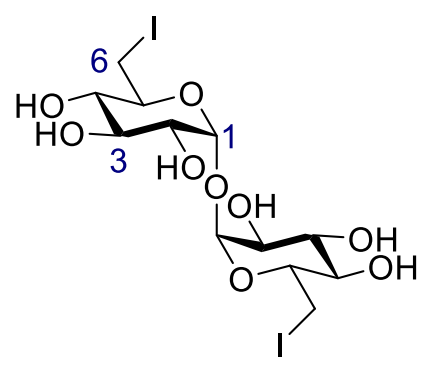

6,6'-Dideoxy-6,6'-diiodo- $\alpha, \alpha^{\prime}$-trehalose (22). $\alpha, \alpha^{\prime}$-Trehalose dihydrate (2.01 g, $5.31 \mathrm{mmol})$ was co-evaporated with DMF (40 mL), then dissolved in $\mathrm{DMF}(60 \mathrm{~mL})$ and the volume reduced by one third. Triphenylphosphine $(6.99 \mathrm{~g}, 26.6 \mathrm{mmol})$ and $\mathrm{I}_{2}(5.41 \mathrm{~g}, 21.3 \mathrm{mmol})$ were added and the resulting solution was stirred at $80^{\circ} \mathrm{C}$ for 2 hours. The mixture was concentrated to one third of the volume, diluted with $\mathrm{MeOH}(80 \mathrm{~mL})$, and the $\mathrm{pH}$ was adjusted to 8 with NaOMe. After stirring for $30 \mathrm{~min}$, the mixture was neutralised with Dowex $-\mathrm{H}^{+}$, filtered, and the resin washed with $\mathrm{MeOH}$. The $\mathrm{MeOH}$ was removed in vacuo and the resultant sludge poured into vigorously stirred water $(80 \mathrm{~mL})$. The solid was removed by filtration over celite and the filtrate extracted with $\mathrm{CH}_{2} \mathrm{Cl}_{2}(3 \times 130 \mathrm{~mL})$. The aqueous layer was concentrated to give a yellow residue which was further purified by $\mathrm{HP} 20$ chromatography $\left(\mathrm{H}_{2} \mathrm{O}\right.$ to $\left.\mathrm{H}_{2} \mathrm{O}: \mathrm{MeOH}, 1: 1, v / v\right)$ to give the title compound as a white solid (2.25 g, $4.00 \mathrm{mmol}, 75 \%)$. $\mathrm{R}_{f}=0.50($ EtOAc:MeOH, 4:1, $v / v) ;[\alpha]_{\mathrm{D}}^{20}=$ +63 ( $c=1.0, \mathrm{H}_{2} \mathrm{O}$ ); IR (film) 3333, 2921, 1607, 1410, 1194, 1146, 1089, 1056, 987, 925, $803 \mathrm{~cm}^{-1}$; ${ }^{1} \mathrm{H}-\mathrm{NMR}\left(500 \mathrm{MHz}, \mathrm{D}_{2} \mathrm{O}\right) \delta 5.25\left(\mathrm{~d}, J_{1,2}=3.8 \mathrm{~Hz}, 2 \mathrm{H}, \mathrm{H}-1\right), 3.86\left(\mathrm{t}, J_{2,3}=J_{3,4}=9.1 \mathrm{~Hz}, 2 \mathrm{H}, \mathrm{H}-3\right)$, $3.67\left(\mathrm{dd}, J_{2,3}=9.9 \mathrm{~Hz}, J_{1,2}=3.9 \mathrm{~Hz}, 2 \mathrm{H}, \mathrm{H}-2\right), 3.64-3.57(\mathrm{~m}, 4 \mathrm{H}, \mathrm{H}-5$ and H-6a), 3.40-3.31 (m, 4H, H4 and H-6b); ${ }^{13} \mathrm{C}-\mathrm{NMR}\left(126 \mathrm{MHz}, \mathrm{D}_{2} \mathrm{O}\right) \delta 93.3$ (C-1), 73.5 (C-4), 71.9 (C-3), 70.9 (C-2), 70.7 (C-5), 6.3 (C-6); HRMS (ESI) $m / z$ [M + Na] ${ }^{+}$calcd. for $\left[\mathrm{C}_{12} \mathrm{H}_{20} \mathrm{I}_{2} \mathrm{O}_{9}+\mathrm{Na}\right]^{+}: 584.9089$, obsd.: 584.9065 .

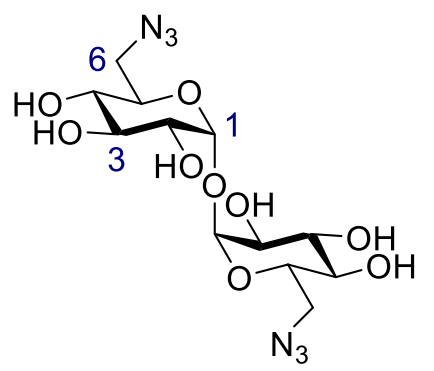

6,6'-Diazido-6,6'-dideoxy- $\alpha, \alpha^{\prime}$-trehalose (23). To a stirred solution of diiodide 22 (218 mg, $0.39 \mathrm{mmol})$ in DMF (5.0 mL) was added sodium azide (151 mg, $2.3 \mathrm{mmol}$ ). The mixture was stirred at $80^{\circ} \mathrm{C}$ for 20 hours and then concentrated. The residue was purified by HP20 chromatography $\left(\mathrm{H}_{2} \mathrm{O}\right.$ to $\left.\mathrm{H}_{2} \mathrm{O}: \mathrm{MeOH}, 1: 1, v / v\right)$ and lyophilised to give the title compound as a white solid (135 mg, $0.34 \mathrm{mmol}, 89 \%) . \mathrm{R}_{f}=0.47\left(\mathrm{CH}_{2} \mathrm{Cl}_{2}: \mathrm{MeOH}, 7: 3 v / v\right) ;[\alpha]_{\mathrm{D}}^{21}$ 
$=+124(c=1.0, \mathrm{MeOH})$; IR (film) 3320, 2954, 2917, 2203, 2104, 1622, 1446, 1411, 1357, 1345, 1286, 1241, 1219, 1149, 1127, 1099, 1066, 1006, 977, 928, 913, 898, 841, $805 \mathrm{~cm}^{-1}$; ${ }^{1} \mathrm{H}-\mathrm{NMR}$ (500 MHz, $\left.\mathrm{D}_{2} \mathrm{O}\right) \delta 5.17\left(\mathrm{~d}, J_{1,2}=3.9 \mathrm{~Hz}, 2 \mathrm{H}, \mathrm{H}-1\right), 3.95\left(\mathrm{ddd}, J_{4,5}=10.0 \mathrm{~Hz}, J_{5,6 \mathrm{~b}}=5.8 \mathrm{~Hz}, J_{5,6 \mathrm{a}}=2.5 \mathrm{~Hz}, 2 \mathrm{H}, \mathrm{H}-\right.$ 5), $3.81\left(\mathrm{t}, J_{2,3}=J_{3,4}=9.6 \mathrm{~Hz}, 2 \mathrm{H}, \mathrm{H}-3\right), 3.68-3.62\left(\mathrm{~m}, 4 \mathrm{H}, \mathrm{H}-2\right.$ and H-6a) $3.54\left(\mathrm{dd}, J_{6 \mathrm{a}}, 6 \mathrm{~b}=13.6 \mathrm{~Hz}\right.$, $\left.J_{5,6 \mathrm{~b}}=5.9 \mathrm{~Hz}, 2 \mathrm{H}, \mathrm{H}-6 \mathrm{~b}\right), 3.44\left(\mathrm{t}, J_{3,4}=J_{4,5}=9.7 \mathrm{~Hz}, 2 \mathrm{H}, \mathrm{H}-4\right) ;{ }^{13} \mathrm{C}-\mathrm{NMR}\left(126 \mathrm{MHz}, \mathrm{D}_{2} \mathrm{O}\right) \delta 93.1(\mathrm{C}-$ 1), 72.2 (C-3), 71.0 (C-5), 70.8 (C-2), 70.4 (C-4), 50.8 (C-6); HRMS (ESI) m/z [M+HCOO]' calcd. for $\left[\mathrm{C}_{12} \mathrm{H}_{20} \mathrm{~N}_{6} \mathrm{O}_{9}+\mathrm{HCOO}^{-}: 437.1274\right.$, obsd. 437.1287.

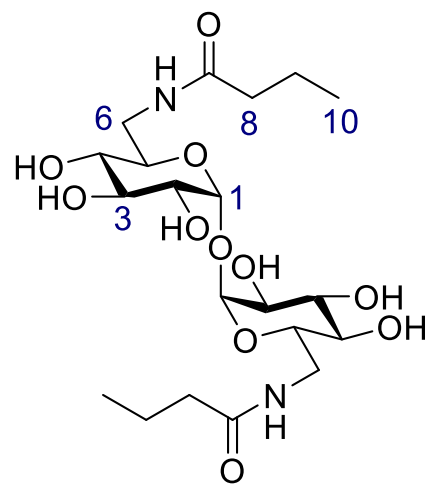

6,6'-Di-butanoylamido-6,6'dideoxy- $\alpha, \alpha^{\prime}$-trehalose (1a). To a stirred solution of $21(88 \mathrm{mg}, 0.22 \mathrm{mmol})$ in $\mathrm{DMF}(2.9 \mathrm{~mL})$ at $0^{\circ} \mathrm{C}$ was added $\mathrm{PMe}_{3}$ in THF (1.0 M, $\left.2.2 \mathrm{~mL}, 2.2 \mathrm{mmol}\right)$ and water $(0.24 \mathrm{~mL}, 13.3 \mathrm{mmol})$. The mixture was stirred for 10 minutes at $0^{\circ} \mathrm{C}$, then allowed to warm to room temperature and stirred for 20 hours. The mixture was concentrated to a colourless gum which was dissolved in $\mathrm{MeOH}(2.9 \mathrm{~mL})$. Butyric anhydride $(0.11 \mathrm{~mL}, 0.67 \mathrm{mmol})$ was added and the resulting mixture stirred for 1.5 hours. The solution was concentrated and the residue was purified by silica gel chromatography $\left(\mathrm{CH}_{2} \mathrm{Cl}_{2}\right.$ to $\left.\mathrm{CH}_{2} \mathrm{Cl}_{2}: \mathrm{MeOH}, 5: 1, v / v\right)$ to give the title compound as a white solid (99 mg, $0.21 \mathrm{mmol}, 92 \%) . \mathrm{R}_{f}=0.45\left(\mathrm{CH}_{2} \mathrm{Cl}_{2}: \mathrm{MeOH}, 7: 3, v / v\right) ;[\alpha]_{\mathrm{D}}^{22}=+73(c=0.9, \mathrm{MeOH}) ; \mathrm{IR}($ film $)$ 3332, 2962, 2933, 2874, 2426, 1617, 1467, 1382, 1336, 1262. 1219, 1145, 1103, 1036, 977, 837, 800 $\mathrm{cm}^{-1} ;{ }^{1} \mathrm{H}-\mathrm{NMR}\left(500 \mathrm{MHz}, \mathrm{CD}_{3} \mathrm{OD}\right) \delta 5.05\left(\mathrm{~d}, J_{1,2}=3.9 \mathrm{~Hz}, 2 \mathrm{H}, \mathrm{H}-1\right), 3.87\left(\mathrm{ddd}, J_{4,5}=9.5 \mathrm{~Hz}, J_{5-6 \mathrm{a}}=\right.$ $\left.5.3 \mathrm{~Hz}, J_{5,6 \mathrm{~b}}=3.6 \mathrm{~Hz}, 2 \mathrm{H}, \mathrm{H}-5\right), 3.76\left(\mathrm{t}, J_{2,3}=J_{3,4}=9.4 \mathrm{~Hz}, 2 \mathrm{H}, \mathrm{H}-3\right), 3.54-3.38(\mathrm{~m}, 3 \mathrm{H}, \mathrm{H}-2, \mathrm{H}-6 \mathrm{a}$ and H-6b), 3.14 (t, $\left.J_{3,4}=J_{4,5}=9.4 \mathrm{~Hz}, 2 \mathrm{H}, \mathrm{H}-4\right), 2.20\left(\mathrm{t}, J_{8,9}=7.4 \mathrm{~Hz}, 4 \mathrm{H}, \mathrm{H}-8\right), 1.64\left(\mathrm{~h}, J_{8,9}=J_{9,10}=\right.$ $7.5 \mathrm{~Hz}, 4 \mathrm{H}, \mathrm{H}-9), 0.95$ (t, $\left.J_{9,10}=7.4 \mathrm{~Hz}, 6 \mathrm{H}, \mathrm{H}-10\right) ;{ }^{13} \mathrm{C}-\mathrm{NMR}\left(126 \mathrm{MHz}, \mathrm{CD}_{3} \mathrm{OD}\right) \delta 176.9(\mathrm{C}=\mathrm{O})$, 95.5 (C-1), 74.1 (C-3), 73.3 (C-2), 73.1 (C-4), 72.1 (C-5), 41.3 (C-6), 38.9 (C-8), 20.5 (C-9), 14.1 (C10); HRMS (ESI) $m / z[\mathrm{M}+\mathrm{H}]^{+}$calcd. for $\left[\mathrm{C}_{20} \mathrm{H}_{36} \mathrm{~N}_{2} \mathrm{O}_{11}+\mathrm{H}\right]^{+}:$481.2392, obsd.: 481.2380 .

General procedure for the Staudinger reduction and coupling reaction. To a stirred solution of diazide 23 in DMF $(0.08 \mathrm{mmol} / \mathrm{mL})$ at $0^{\circ} \mathrm{C}$ were added $1.0 \mathrm{M} \mathrm{PMe} 3$ in THF (10 equiv.) and water (60 equiv.). The solution was stirred for 10 minutes at $0^{\circ} \mathrm{C}$, then allowed to warm to room temperature, and stirred for a further 20 hours. The mixture was concentrated and the residue co-evaporated with distilled pyridine $(0.02 \mathrm{mmol} / \mathrm{mL}) \times 2$ and then dissolved in distilled pyridine $(0.02 \mathrm{mmol} / \mathrm{mL})$. To this solution was added carboxylic acid (2.5 equiv.), DIPEA (5 equiv.) and then HBTU (2.5 equiv.). The 
reaction mixture was stirred overnight at room temperature and then concentrated. The residue was purified as detailed in individual procedure.

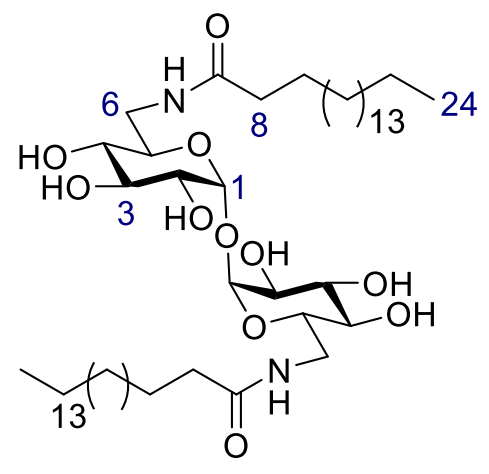

6,6'-Dideoxy-6,6'-di-stearoylamido- $\alpha, \alpha^{\prime}$-trehalose (1b). Di-azide 23 (154 mg, $0.39 \mathrm{mmol}), \mathrm{PMe}_{3}(4.0 \mathrm{~mL}, 4.0 \mathrm{mmol})$, water $(0.42 \mathrm{~mL}, 23.3$ mmol), stearic acid (287 mg, $1.0 \mathrm{mmol})$, DIPEA (0.34 mL, $2.0 \mathrm{mmol})$, and HBTU (372 mg, $1.0 \mathrm{mmol}$ ) were subjected to the general procedure for the Staudinger reduction and coupling reaction. The crude product was dissolved in ${ }^{t} \mathrm{BuOH}: \mathrm{EtOAc}(50 \mathrm{~mL}, 2: 1, v / v)$ and washed with $\mathrm{HCl}$ $(2 \times 50 \mathrm{~mL}, 1.0 \mathrm{M})$, sat. $\mathrm{NaHCO}_{3}(2 \times 50 \mathrm{~mL})$ and brine $(2 \times 50 \mathrm{~mL})$.

The organic layer was dried $\left(\mathrm{MgSO}_{4}\right)$, filtered and concentrated. The residue was purified by gradient silica gel flash chromatography $\left(\mathrm{CH}_{2} \mathrm{Cl}_{2}\right.$ to $\left.85: 15 \mathrm{CH}_{2} \mathrm{Cl}_{2}: \mathrm{MeOH} v / v\right)$ to give the title compound as a white solid (278 mg, $0.32 \mathrm{mmol}, 81 \%) . \mathrm{R}_{f}=0.55\left(4: 1 \mathrm{CH}_{2} \mathrm{Cl}_{2}: \mathrm{MeOH} v / v\right) ;[\alpha]_{\mathrm{D}}^{22}=+46(c=1.0$, pyridine); IR (film) 3586, 3545, 3443, 3357, 2918, 2850, 1652, 1634, 1534, 1467, 1319, 1150, 1031, 1010, 848, 838, $557 \mathrm{~cm}^{-1}$; ${ }^{1} \mathrm{H}-\mathrm{NMR}\left(500 \mathrm{MHz}, \mathrm{C}_{5} \mathrm{D}_{5} \mathrm{~N}\right) \delta 8.86(\mathrm{~s}, 2 \mathrm{H}, \mathrm{NH}), 5.73\left(\mathrm{~d}, J_{1,2}=3.3 \mathrm{~Hz}, 2 \mathrm{H}\right.$, H-1), 4.97-4.87 (m, 2H, H-5), 4.70 (t, $\left.J_{2,3}=J_{3,4}=9.3 \mathrm{~Hz}, 2 \mathrm{H}, \mathrm{H}-3\right), 4.28-4.16$ (m, 4H, H-2 and H-6a), $3.96\left(\mathrm{t}, J_{3,4}=J_{4,5}=9.4 \mathrm{~Hz}, 2 \mathrm{H}, \mathrm{H}-4\right), 3.90\left(\mathrm{~d}, J_{6 \mathrm{a}, 6 \mathrm{~b}}=12.7 \mathrm{~Hz}, 2 \mathrm{H}, \mathrm{H}-6 \mathrm{~b}\right), 2.41\left(\mathrm{~m}, 4 \mathrm{H}, \mathrm{CH}_{2}-8\right), 1.75$ $\left(\mathrm{p}, J_{8,9}=J_{8,10}=7.7 \mathrm{~Hz}, 4 \mathrm{H}, \mathrm{CH}_{2}-9\right), 1.34-1.17\left(\mathrm{~m}, 56 \mathrm{H}, \mathrm{CH}_{2}-10-\mathrm{CH}_{2}-23\right), 0.88\left(\mathrm{t}, J_{23-24}=7.0 \mathrm{~Hz}\right.$, $\left.6 \mathrm{H}, \mathrm{CH}_{3}-24\right) ;{ }^{13} \mathrm{C}-\mathrm{NMR}\left(125 \mathrm{MHz}, \mathrm{C}_{5} \mathrm{D}_{5} \mathrm{~N}\right) \delta 175.3(\mathrm{C}=\mathrm{O}), 97.0(\mathrm{C}-1), 74.5(\mathrm{C}-3), 73.9(\mathrm{C}-2), 73.3$ (C-4), 72.9 (C-5), 41.5 (C-6), $37.0\left(\mathrm{CH}_{2}-8\right), 32.6,30.46,30.5,30.44,30.41,30.40,30.38,30.3,30.14$, 30.06, $23.4\left(\mathrm{CH}_{2}-10-\mathrm{CH}_{2}-23\right), 26.7\left(\mathrm{CH}_{2}-9\right), 14.7\left(\mathrm{CH}_{3}-24\right)$; HRMS (ESI) $m / z[\mathrm{M}+\mathrm{H}]^{+}$calcd. for $\left[\mathrm{C}_{48} \mathrm{H}_{92} \mathrm{~N}_{2} \mathrm{O}_{11}+\mathrm{H}\right]^{+}:$873.6774, obsd. 873.6770.

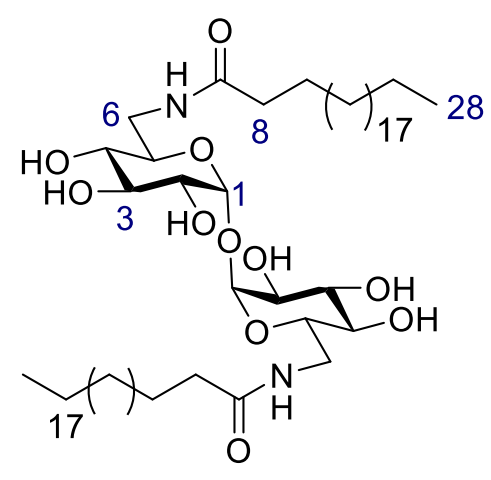

6,6'-Di-behenoylamido-6,6'-dideoxy- $\alpha, \alpha^{\prime}$-trehalose (1c). Di-azide 23 (54 mg, $0.14 \mathrm{mmol}), \mathrm{PMe}_{3}(1.4 \mathrm{~mL}, 1.4 \mathrm{mmol})$, water $(0.15 \mathrm{~mL}, 8.3$ mmol), behenic acid (119 mg, $0.35 \mathrm{mmol})$, DIPEA (0.12 mL, 0.69 mmol), and HBTU (132 $\mathrm{mg}, 0.35 \mathrm{mmol})$ were subjected to the general procedure for the Staudinger reduction and coupling reaction. The resultant residue was dissolved in hot ${ }^{t} \mathrm{BuOH}:$ EtOAc $(30 \mathrm{~mL}, 2: 1, v / v)$ and washed with $\mathrm{HCl}(30 \mathrm{~mL}, 1.0 \mathrm{M})$, sat. $\mathrm{NaHCO}_{3}(30 \mathrm{~mL})$ and brine (30 mL). The organic layer was dried $\left(\mathrm{MgSO}_{4}\right)$, and filtered (washing the $\mathrm{MgSO}_{4}$ thoroughly with pyridine) and concentrated. The residue was purified by gradient silica gel flash chromatography 
$\left(\mathrm{CH}_{2} \mathrm{Cl}_{2}\right.$ to $\left.\mathrm{CH}_{2} \mathrm{Cl}_{2}: \mathrm{MeOH}, 85: 15, v / v\right)$ to give the title compound as a white solid (108 $\mathrm{mg}, 0.11 \mathrm{mmol}$, $79 \%) . \mathrm{R}_{f}=0.56\left(\mathrm{CH}_{2} \mathrm{Cl}_{2}: \mathrm{MeOH}, 4: 1, v / v\right) ;[\alpha]_{\mathrm{D}}^{22}=+39(c=1.0$, pyridine); IR (film) 3330, 2915, 2849, 1636, 1541, 1491, 1468, 1377, 1147, 1103, 1080, 1039, 993, $842 \mathrm{~cm}^{-1} ; \mathrm{H}-\mathrm{NMR}\left(500 \mathrm{MHz}, \mathrm{C}_{5} \mathrm{D}_{5} \mathrm{~N}\right) \delta$ $5.75\left(\mathrm{~d}, J_{1,2}=4.0 \mathrm{~Hz}, 2 \mathrm{H}, \mathrm{H}-1\right), 4.94\left(\mathrm{ddd}, J_{4,5}=9.6 \mathrm{~Hz}, J_{5,6 \mathrm{a}}=4.6 \mathrm{~Hz}, \mathrm{~J}_{5,6 \mathrm{~b}}=2.9 \mathrm{~Hz}, 2 \mathrm{H}, \mathrm{H}-5\right), 4.69$ (t, $\left.J_{2,3}=J_{3,4}=9.3 \mathrm{~Hz}, 2 \mathrm{H}, \mathrm{H}-3\right), 4.25\left(\mathrm{~m}, 4 \mathrm{H}, \mathrm{H}-2\right.$ and H-6a), 3.97 (m, 4H, H-4 and H-6b), 2.43 (t, $J_{8,9}$ $=7.5 \mathrm{~Hz}, 4 \mathrm{H}, \mathrm{H}-8), 1.78$ (p, $\left.J_{8,9}=J_{9,10}=7.7 \mathrm{~Hz}, 4 \mathrm{H}, \mathrm{H}-9\right), 1.36-1.15$ (m, 72H, H-10 - H-27), 0.88 (t, $\left.J_{27,28}=7.1 \mathrm{~Hz}, 6 \mathrm{H}, \mathrm{H}-28\right) ;{ }^{13} \mathrm{C}-\mathrm{NMR}\left(126 \mathrm{MHz}, \mathrm{C}_{5} \mathrm{D}_{5} \mathrm{~N}\right) \delta 175.3(\mathrm{C}=\mathrm{O}), 97.2(\mathrm{C}-1), 74.8(\mathrm{C}-3), 74.2$ (C-2), 73.7 (C-4), 73.1 (C-5) 41.8 (C-6), 37.2 (C-8), 32.8, 30.71, 30.70, 30.69, 30.67, 30.66, 30.64, 30.60, 30.5, 30.4, 30.3, 23.62 (C-10 - C-27) 27.0 (C-9), 15.0 (C-28); HRMS (ESI) $\mathrm{m} / \mathrm{z}[\mathrm{M}+\mathrm{H}]^{+}$calcd. for $\left[\mathrm{C}_{56} \mathrm{H}_{108} \mathrm{~N}_{2} \mathrm{O}_{11}+\mathrm{H}\right]^{+}$: 985.8026, obsd. 985.8052.

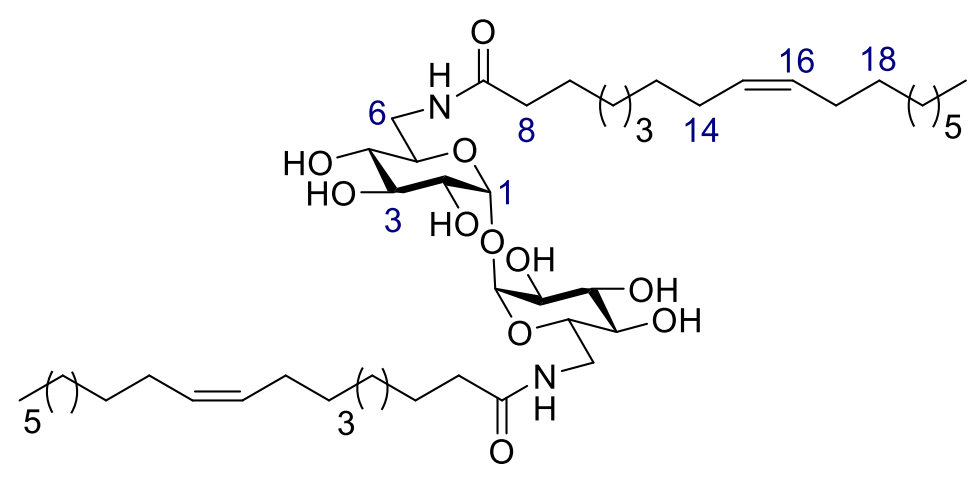

6,6'-Dideoxy-di-oleoylamido- $\alpha, \alpha^{\prime}-$ trehalose (1d). Di-azide 23 (55 mg, 0.14 $\mathrm{mmol}), \mathrm{PMe}_{3}(1.4 \mathrm{~mL}, 1.4 \mathrm{mmol})$, water $(0.15 \mathrm{~mL}, 8.3 \mathrm{mmol})$, oleic acid $(0.11 \mathrm{~mL}$, $0.35 \mathrm{mmol})$, DIPEA $(0.12 \mathrm{~mL}, 0.69$ mmol), and HBTU (134 mg, $0.35 \mathrm{mmol})$ were subjected to the general procedure for the Staudinger reduction and coupling reaction. The resultant residue was dissolved in 2:1 ${ }^{t} \mathrm{BuOH}:$ EtOAc $(40 \mathrm{~mL}, 2: 1, v / v)$ and washed with $\mathrm{HCl}(50 \mathrm{~mL}, 1.0 \mathrm{M})$, sat. $\mathrm{NaHCO}_{3}(50 \mathrm{~mL})$ and brine $(50 \mathrm{~mL})$. The organic layer was dried $\left(\mathrm{MgSO}_{4}\right)$, filtered and concentrated. The residue was purified by gradient silica gel flash chromatography $\left(\mathrm{CH}_{2} \mathrm{Cl}_{2}\right.$ to $\left.\mathrm{CH}_{2} \mathrm{Cl}_{2}: \mathrm{MeOH}, 85: 15, v / v\right)$ to give the title compound as a white solid (98 mg, $0.11 \mathrm{mmol}, 80 \%)$. $\mathrm{R}_{f}=0.50\left(\mathrm{CH}_{2} \mathrm{Cl}_{2}: \mathrm{MeOH}, 4: 1, v / v\right) ;[\alpha]_{\mathrm{D}}^{24}$ $=+44(c=1.0$, pyridine); IR (film) 3310, 3005, 2922, 2853, 1646, 1532, 1459, 1432, 1146, 1103, 1078, 1056, 1034, 1017, 990, 941, $845 \mathrm{~cm}^{-1} ;{ }^{1} \mathrm{H}-\mathrm{NMR}\left(500 \mathrm{MHz}, \mathrm{C}_{5} \mathrm{D}_{5} \mathrm{~N}\right) \delta 5.73\left(\mathrm{~d}, J_{1,2}=3.6 \mathrm{~Hz}, 2 \mathrm{H}\right.$, H-1), 5.48 (m, 4H, H-15 and H-16), 4.93 (m, 2H, H-5), 4.67 (t, $J_{2,3}=J_{3,4}=9.3$ Hz, 2H, H-3), 4.24 (m, 4H, H-2 and H-6a), 3.95 (m, H-4 and H-6b), 2.41 (t, $J_{8,9}=7.3$ Hz, 4H, H-8), 2.08 (m, 8H, H-14 and H-17), 1.75 (p, $\left.J_{8,9}=J_{9.10}=7.1 \mathrm{~Hz}, 4 \mathrm{H}, \mathrm{H}-9\right), 1.44-1.11$ (m, 40H, H-10 - H-13 and H-18 - H-23), 0.87 (t, $\left.J_{23,24}=6.3 \mathrm{~Hz}, 6 \mathrm{H}, \mathrm{H}-24\right) ;{ }^{13} \mathrm{C}-\mathrm{NMR}\left(126 \mathrm{MHz}, \mathrm{C}_{5} \mathrm{D}_{5} \mathrm{~N}\right) 175.2(\mathrm{C}=\mathrm{O}), 130.7(\mathrm{C}-15$ and C-16), 97.1 (C-1), 74.6 (C-3), 74.0 (C-2), 73.4 (C-4), 72.9 (C-5), 41.6 (C-6), 37.0 (C-8), 32.6, 30.54, 30.52, 30.48, 30.3, 30.2 30.08, 30.05, 30.03, 29.9, 23.4 (C-10 - C-13 and C-18 - C-23), 28.0 (C-14 and C-17), 26.8 (C-9), 14.8 (C-24); HRMS (ESI) $m / z[\mathrm{M}+\mathrm{H}]^{+}$calcd. for $\left[\mathrm{C}_{48} \mathrm{H}_{88} \mathrm{~N}_{2} \mathrm{O}_{11}+\mathrm{H}\right]^{+}:$869.6461, obsd. 869.6490. 


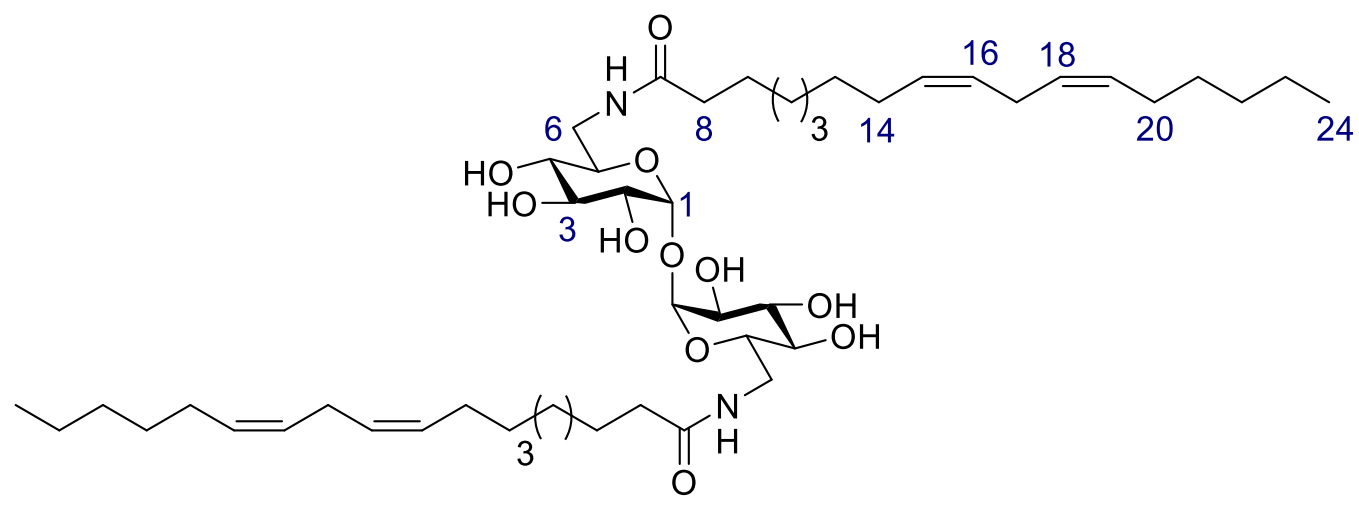

6,6'-Dideoxy-di-linoleoylamido- $\boldsymbol{\alpha}, \boldsymbol{\alpha}^{\prime}$-trehalose (1e). Di-azide 23 (57 mg, $0.15 \mathrm{mmol}$ ), $\mathrm{PMe}_{3}$ (1.5 mL. $1.5 \mathrm{mmol})$, water $(0.16 \mathrm{~mL}, 8.9 \mathrm{mmol})$, linoleic acid $(99 \mathrm{mg}, 0.35 \mathrm{mmol})$, DIPEA (0.13 mL, 0.75 mmol), and HBTU (139 mg, $0.37 \mathrm{mmol}$ ) were subjected to the general procedure for the Staudinger reduction and coupling reaction. The resultant residue was dissolved in ${ }^{t} \mathrm{BuOH}$ :EtOAc (40 mL, 2:1, $v / v)$ and washed with $\mathrm{HCl}(50 \mathrm{~mL}, 1.0 \mathrm{M})$, sat. $\mathrm{NaHCO}_{3}(50 \mathrm{~mL})$ and brine $(50 \mathrm{~mL})$. The organic layer was dried $\left(\mathrm{MgSO}_{4}\right)$, filtered and concentrated. The resultant residue was purified by gradient silica gel flash chromatography $\left(\mathrm{CH}_{2} \mathrm{Cl}_{2}\right.$ to $\left.\mathrm{CH}_{2} \mathrm{Cl}_{2}: \mathrm{MeOH}, 85: 15, v / v\right)$ to give the title compound as a white solid (93 mg, $0.11 \mathrm{mmol}, 74 \%) . \mathrm{R}_{f}=0.61\left(\mathrm{CH}_{2} \mathrm{Cl}_{2}: \mathrm{MeOH}, 4: 1, v / v\right) ;[\alpha]_{\mathrm{D}}^{25}=+37(c=0.9$, pyridine); IR (film) 3306, 3009, 2924, 2854, 1638, 1543, 1456, 1433, 1396, 1376, 1271, 1146, 1102, 1078, 1035, 991, 941, 845, $805 \mathrm{~cm}^{-1}$; ${ }^{1} \mathrm{H}-\mathrm{NMR}\left(500 \mathrm{MHz}, \mathrm{C}_{5} \mathrm{D}_{5} \mathrm{~N}\right) \delta 8.65\left(\mathrm{bt}, J_{\mathrm{NH}, \mathrm{H}-6}=6.0 \mathrm{~Hz}, 2 \mathrm{H}, \mathrm{NH}\right), 5.75(\mathrm{~d}$, $\left.J_{1,2}=3.8 \mathrm{~Hz}, 2 \mathrm{H}, \mathrm{H}-1\right), 5.49$ (m, 8H, H-15, H-16, H-18 and H-19), 4.94 (ddd, $J_{4-5}=9.8, J_{5-6 \mathrm{a}}=4.9, J_{5-}$ $6 \mathrm{~b}=3.0,2 \mathrm{H}, \mathrm{H}-5), 4.68\left(\mathrm{t}, J_{2,3}=J_{3,4}=9.1 \mathrm{~Hz}, 2 \mathrm{H}, \mathrm{H}-3\right), 4.25(\mathrm{~m}, 4 \mathrm{H}, \mathrm{H}-2$ and H-6a), 3.97 (m, 4H, H4 and H-6b), 2.91 (t, $\left.J_{16,17}=J_{17,18}=5.9 \mathrm{~Hz}, 4 \mathrm{H}, \mathrm{H}-17\right), 2.40(\mathrm{~m}, 4 \mathrm{H}, \mathrm{H}-8), 2.09\left(\mathrm{~m}, 8 \mathrm{H}, \mathrm{CH}_{2}-14\right.$ and $\left.\mathrm{CH}_{2}-20\right), 1.76\left(\mathrm{p}, J_{8,9}=J_{9,10}=7.5 \mathrm{~Hz}, 2 \mathrm{H}, \mathrm{H}-9\right), 1.40-1.16(\mathrm{~m}, 28 \mathrm{H}, \mathrm{H}-10-\mathrm{H}-13$ and H-21 $-\mathrm{H}-23)$, 0.86, $\left(\mathrm{t}, J_{23-24}=6.8 \mathrm{~Hz}, 3 \mathrm{H}, \mathrm{H}-24\right) ;{ }^{13} \mathrm{C}-\mathrm{NMR}\left(125 \mathrm{MHz}, \mathrm{C}_{5} \mathrm{D}_{5} \mathrm{~N}\right) \delta 175.0(\mathrm{C}=\mathrm{O}), 130.9,128.8(\mathrm{C}-15$, C-16, C-18 and C-19), 97.1 (C-1) 74.7 (C-3), 74.1 (C-2), 73.5 (C-4), 72.9 (C-5), 41.6 (C-6) 37.0 (C8), 32.1, 30.4, 30.14, 30.07, 30.06, 29.9, 28.0, 23.3 (C-10 - C-13 and C-21 - C-23), 27.9 (C-9), 26.5 (C-17), 14.7 (C-24); HRMS (ESI) $m / z,[\mathrm{M}+\mathrm{H}]^{+}$calcd. for $\left[\mathrm{C}_{48} \mathrm{H}_{84} \mathrm{~N}_{2} \mathrm{O}_{11}+\mathrm{H}\right]^{+}:$865.6148, obsd. 865.6183 .

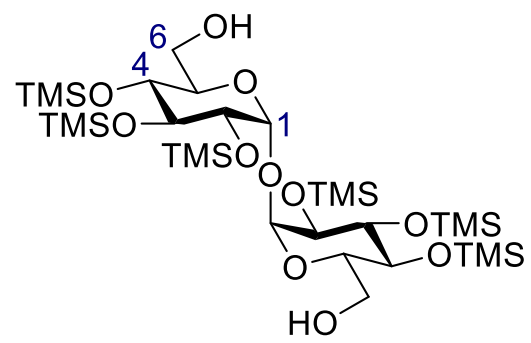

$2,2^{\prime}, 3,3^{\prime}, 4,4^{\prime}$-Hexa- $O$-trimethylsilyl- $\alpha, \alpha^{\prime}$-trehalose $\quad(25) . \quad \alpha, \alpha^{\prime}-$ trehalose dihydrate $(3.00 \mathrm{~g}, 7.9 \mathrm{mmol})$ was co-evaporated with DMF (25 $\mathrm{mL} x 2)$, then dissolved in DMF (25 mL) and the volume reduced by approximately a half. To this solution was added BSA $(17.0 \mathrm{~mL}$, $70 \mathrm{mmol}$ ) and TBAF (1 M in THF, $0.5 \mathrm{~mL}, 0.50 \mathrm{mmol})$ and, the mixture stirred for 2 hours. The reaction was quenched by the addition of isopropanol $(3 \mathrm{~mL})$, diluted 
with $\mathrm{MeOH}(150 \mathrm{~mL})$, cooled to $0^{\circ} \mathrm{C}$ and $\mathrm{K}_{2} \mathrm{CO}_{3}(1.10 \mathrm{~g}, 7.9 \mathrm{mmol})$ was added. The reaction was stirred for 1.5 hour at $0^{\circ} \mathrm{C}$, neutralised with $\mathrm{AcOH}(0.6 \mathrm{~mL})$ and the $\mathrm{MeOH}$ removed in vacuo. The mixture was diluted with EtOAc $(180 \mathrm{~mL})$ and washed with brine $(175 \mathrm{~mL})$. The brine layer was extracted with EtOAc (3 x $180 \mathrm{~mL})$ and the combined organic layers were dried $\left(\mathrm{MgSO}_{4}\right)$, filtered and concentrated. The resultant yellow solid was purified by gradient silica gel flash column chromatography (Petroleum ether to Petroleum ether:EtOAc, 4:1, v/v) to give the title compound as a white solid (4.70 g, $6.1 \mathrm{mmol}, 76 \%) . \mathrm{R}_{f}=0.29$ (Petroleum ether:EtOAc, 3:1, v/v); $[\alpha]_{\mathrm{D}}^{22}=+106(c=$ 1.0, $\mathrm{CH}_{2} \mathrm{Cl}_{2}$ ); IR (film) 3504, 2956, 1386, 1249, 1165, 1108, 1074, 1005, 946, 896, $833 \mathrm{~cm}^{-1}$; ${ }^{1} \mathrm{H}-\mathrm{NMR}$ $\left(500 \mathrm{MHz}, \mathrm{CDCl}_{3}\right) \delta 4.90\left(\mathrm{~d}, J_{1,2}=3.1 \mathrm{~Hz}, 2 \mathrm{H}, \mathrm{H}-1\right), 3.88\left(\mathrm{t}, J_{2,3}=J_{3,4}=9.0 \mathrm{~Hz}, 2 \mathrm{H}, \mathrm{H}-3\right), 3.84(\mathrm{~m}$, $2 \mathrm{H}, \mathrm{H}-5), 3.72\left(\mathrm{dd}, J_{6 \mathrm{a}, 6 \mathrm{~b}}=11.7 \mathrm{~Hz}, J_{5,6 \mathrm{a}}=2.9 \mathrm{~Hz}, 2 \mathrm{H}, \mathrm{H}-6 \mathrm{a}\right), 3.68\left(\mathrm{dd}, J_{6 \mathrm{a}, 6 \mathrm{~b}}=11.8 \mathrm{~Hz}, J_{5,6 \mathrm{~b}}=3.8 \mathrm{~Hz}\right.$, $2 \mathrm{H}, \mathrm{H}-6 \mathrm{~b}), 3.47\left(\mathrm{t}, J_{3,4}=J_{4,5}=9.1 \mathrm{~Hz}, 2 \mathrm{H}, \mathrm{H}-4\right), 3.42$ (dd, $\left.J_{2,3}=9.4 \mathrm{~Hz}, J_{1,2}=3.2 \mathrm{~Hz}, 2 \mathrm{H}, \mathrm{H}-2\right), 0.16$, 0.14, 0.12 (3 s, 54H, $\left.\mathrm{CH}_{3}, \mathrm{TMS}\right) ;{ }^{13} \mathrm{C}-\mathrm{NMR}\left(125 \mathrm{MHz}, \mathrm{CDCl}_{3}\right) \delta 94.8$ (C-1), 73.5 (C-3), 73.1 (C-5), 72.9 (C-2), 71.5 (C-4). 61.8 (C-6), 1.2, 1.0, 0.2 (TMS); HRMS (ESI) $m / z$ [M+NH4 $]^{+}$calcd. for $\left[\mathrm{C}_{30} \mathrm{H}_{70} \mathrm{O}_{11} \mathrm{Si}_{6}+\mathrm{NH}_{4}\right]^{+}:$792.3872, obsd. 792.3899 .

General procedure for esterification reactions. Diol (25) was co-evaporated with dry toluene $(0.13$ $\mathrm{mmol} / \mathrm{mL})$ and then dissolved in dry toluene $(0.13 \mathrm{mmol} / \mathrm{mL})$. To this solution were added the carboxylic acid (5.0 equiv.), EDCI (6.5 equiv.) and DMAP (2.0 equiv.), and the solution was heated to $70-80^{\circ} \mathrm{C}$. After 20 hours, the mixture was diluted with EtOAc, washed with water and brine. The organic layer was dried $\left(\mathrm{MgSO}_{4}\right)$, filtered and concentrated to give the crude product. The product was purified as detailed in each individual procedure.

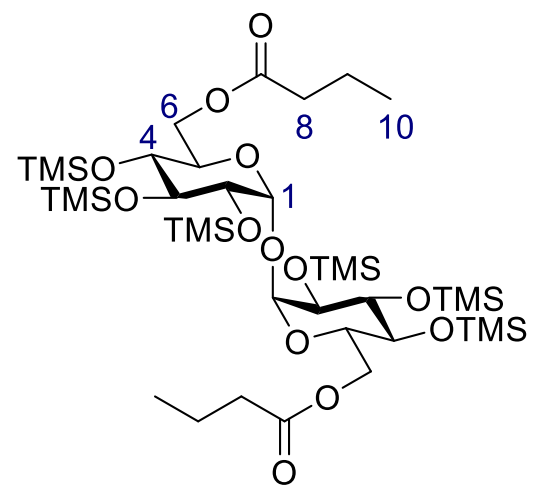

\section{$2,2^{\prime}, 3,3^{\prime}, 4,4^{\prime}$-Hexa-O-trimethylsilyl-6,6'-di- $O$-butanoyl- $\alpha, \alpha^{\prime}-$} trehalose (27a) Diol 25 (303 mg, $0.39 \mathrm{mmol})$, butyric acid $(0.18 \mathrm{~mL}$, $2.0 \mathrm{mmol}$ ), EDCI (488 mg, $2.5 \mathrm{mmol})$ and DMAP (96 mg, 0.78 mmol) were subjected to the general procedure for esterification reactions. The crude product was purified by gradient silica gel flash column chromatography (petroleum ether to petroleum ether:EtOAc, 95:5, $v / v)$ to give the title compound as a white solid (328 $\mathrm{mg}, 0.36$ mmol, 92\%). $\mathrm{R}_{f}=0.54$ (petroleum ether:EtOAc, 4:1, v/v); $[\alpha]_{\mathrm{D}}^{22}=+97\left(c=1.0, \mathrm{CH}_{2} \mathrm{Cl}_{2}\right) ; \mathrm{IR}($ film) 2959. 1735, 1457, 1366, 1304, 1247, 1189, 1164, 1144, 1110, 1076, 1047, 1010, 967, 938, 893, 869, $834 \mathrm{~cm}^{-1} ;{ }^{1} \mathrm{H}-\mathrm{NMR}\left(500 \mathrm{MHz}, \mathrm{CDCl}_{3}\right) \delta 4.94\left(\mathrm{~d}, J_{1,2}=3.1 \mathrm{~Hz}, 2 \mathrm{H}, \mathrm{H}-1\right), 4.30\left(\mathrm{dd}, J_{6 \mathrm{a}, 6 \mathrm{~b}}=11.9 \mathrm{~Hz}, J_{5,6 \mathrm{a}}\right.$ $=2.4 \mathrm{~Hz}, 2 \mathrm{H}, \mathrm{H}-6 \mathrm{a}), 4.08\left(\mathrm{dd}, J_{6 \mathrm{a}, 6 \mathrm{~b}}=11.9 \mathrm{~Hz}, J_{5,6 \mathrm{~b}}=4.5 \mathrm{~Hz}, 2 \mathrm{H}, \mathrm{H}-6 \mathrm{~b}\right), 4.01\left(\mathrm{ddd}, J_{4,5}=9.4 \mathrm{~Hz}, J_{5,6 \mathrm{~b}}\right.$ $\left.=4.3 \mathrm{~Hz}, J_{5,6 \mathrm{a}}=2.2 \mathrm{~Hz}, 2 \mathrm{H}, \mathrm{H}-5\right), 3.92\left(\mathrm{t}, J_{2,3}=J_{3,4}=8.9 \mathrm{~Hz}, 2 \mathrm{H}, \mathrm{H}-3\right), 3.49\left(\mathrm{t}, J_{3,4}=J_{4,5}=9.3 \mathrm{~Hz}, 2 \mathrm{H}\right.$, 
H-4), $3.46\left(\mathrm{dd}, J_{2,3}=9.3 \mathrm{~Hz}, J_{1,2}=3.1 \mathrm{~Hz}, 2 \mathrm{H}, \mathrm{H}-2\right), 2.41-2.26(\mathrm{~m}, 4 \mathrm{H}, \mathrm{H}-8), 1.68$ (m, 4H, H-9), 0.97 $\left(\mathrm{t}, J_{9,10}=7.3 \mathrm{~Hz}, 6 \mathrm{H}, \mathrm{H}-10\right) 0.17,0.15,0.15\left(3 \mathrm{~s}, 54 \mathrm{H}, \mathrm{CH}_{3}, \mathrm{TMS}\right) ;{ }^{13} \mathrm{C}-\mathrm{NMR}\left(125 \mathrm{MHz}, \mathrm{CDCl}_{3}\right) \delta$ 173.7 (C=O), 94.5 (C-1), 73.6 (C-3), 72.8 (C-2), 72.1 (C-4), 70.9 (H-4), 63.4 (C-6), 36.2 (C-8), 18.4 (C-9). 13.8 (C-10), 1.2, 1.0, 0.3 (TMS); HRMS (ESI) $m / z\left[\mathrm{M}+\mathrm{NH}_{4}\right]^{+}$calcd. for $\left[\mathrm{C}_{38} \mathrm{H}_{82} \mathrm{O}_{13} \mathrm{Si}_{6}+\mathrm{NH}_{4}\right]^{+}$: 932.4709, obsd.: 932.4705.

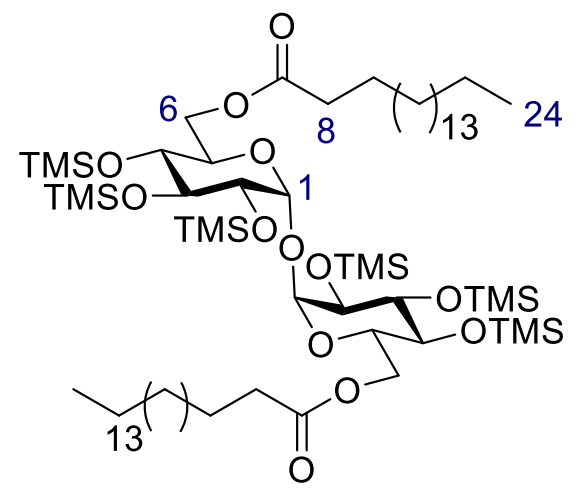

\title{
$2,2^{\prime}, 3,3^{\prime}, 4,4^{\prime}$-Hexa- $O$-trimethylsilyl-6,6 $6^{\prime}$-di- $O$-stearoyl- $\alpha, \alpha^{\prime}-$
} trehalose (27b). Diol 25 (306 $\mathrm{mg}, 0.39 \mathrm{mmol})$, stearic acid (562 $\mathrm{mg}, 2.0 \mathrm{mmol})$, EDCI (493 mg, $2.6 \mathrm{mmol})$, and DMAP (0.79 mmol) were subjected to the general procedure for esterification reactions. The crude product was purified by silica gel flash column chromatography (petroleum ether to petroleum ether:EtOAc, 95:15, v/v) to give the title compound as a colourless oil (514 mg, $0.39 \mathrm{mmol}, 99 \%) . \mathrm{R}_{f}=0.42$ (petroleum ether:EtOAc, 9:1, $\left.v / v\right) ;[\alpha]_{\mathrm{D}}^{23}=+66(c=1.0$, $\mathrm{CH}_{2} \mathrm{Cl}_{2}$ ); IR (film) 2922, 2853, 1742, 1458, 1250, 1164, 1110, 1099, 1075, 1045, 965, 897, 870, 836 $\mathrm{cm}^{-1} ;{ }^{1} \mathrm{H}-\mathrm{NMR}\left(500 \mathrm{MHz}, \mathrm{CDCl}_{3}\right) \delta 4.92\left(\mathrm{~d}, J_{1,2}=3.1 \mathrm{~Hz}, 2 \mathrm{H}, \mathrm{H}-1\right), 4.27\left(\mathrm{dd}, J_{6 \mathrm{a}, 6 \mathrm{~b}}=11.9 \mathrm{~Hz}, J_{5,6 \mathrm{a}}=\right.$ $2.4 \mathrm{~Hz}, 2 \mathrm{H}, \mathrm{H}-6 \mathrm{a}), 4.05\left(\mathrm{dd}, J_{6 \mathrm{a}, 6 \mathrm{~b}}=11.9 \mathrm{~Hz}, J_{5,6 \mathrm{~b}}=4.4 \mathrm{~Hz}, 2 \mathrm{H}, \mathrm{H}-6 \mathrm{~b}\right), 4.00\left(\mathrm{ddd}, J_{4,5}=9.4 \mathrm{~Hz}, J_{5,6 \mathrm{~b}}=\right.$ $\left.4.3 \mathrm{~Hz}, J_{5,6 \mathrm{a}}=2.1 \mathrm{~Hz}, 2 \mathrm{H}, \mathrm{H}-5\right), 3.90$ (t, $\left.J_{2,3}=J_{3,4}=8.9 \mathrm{~Hz}, 2 \mathrm{H}, \mathrm{H}-3\right), 3.48$ (t, $J_{3,4}=J_{4,5}=9.1 \mathrm{~Hz}, 2 \mathrm{H}$, H-4), 3.44 (dd, $\left.J_{2,3}=9.2 \mathrm{~Hz}, J_{1,2}=3.1 \mathrm{~Hz}, 2 \mathrm{H}, \mathrm{H}-2\right), 2.39-2.28$ (m, 4H, H-8), 1.66-1.51 (m, 8H, H-9 \& H-10), 1.35-1.19 (m, 26H, H-11 - H-23), 0.88 (t, $\left.J_{23,24}=6.8 \mathrm{~Hz}, 6 \mathrm{H}, \mathrm{H}-24\right), 0.15,0.13,0.13(3 \mathrm{~s}$, 54H, $\left.\mathrm{CH}_{3} \mathrm{TMS}\right) ;{ }^{13} \mathrm{C}-\mathrm{NMR}\left(125 \mathrm{MHz}, \mathrm{CDCl}_{3}\right) 173.9(\mathrm{C}=\mathrm{O}), 94.5$ (C-1), 73.6 (C-3), 72.8 (C-2), 72.1 (C-4), 70.9 (C-5), 63.5 (C-6), 34.3 (C-8), 32.1, 29.9, 29.82, 29.79, 29.6, 29.52, 29.47, 29.3, 25.0 (C11 - C23), 22.9 (C-9 \& C-10), 14.3 (C-24), 2.1, 1.2, 0.3 (TMS); HRMS (ESI) $m / z$ [M+Na] ${ }^{+}$calcd. for $\left[\mathrm{C}_{66} \mathrm{H}_{138} \mathrm{O}_{13} \mathrm{Si}_{6}+\mathrm{Na}\right]^{+}:$1329.8645, obsd. 1329.8596.

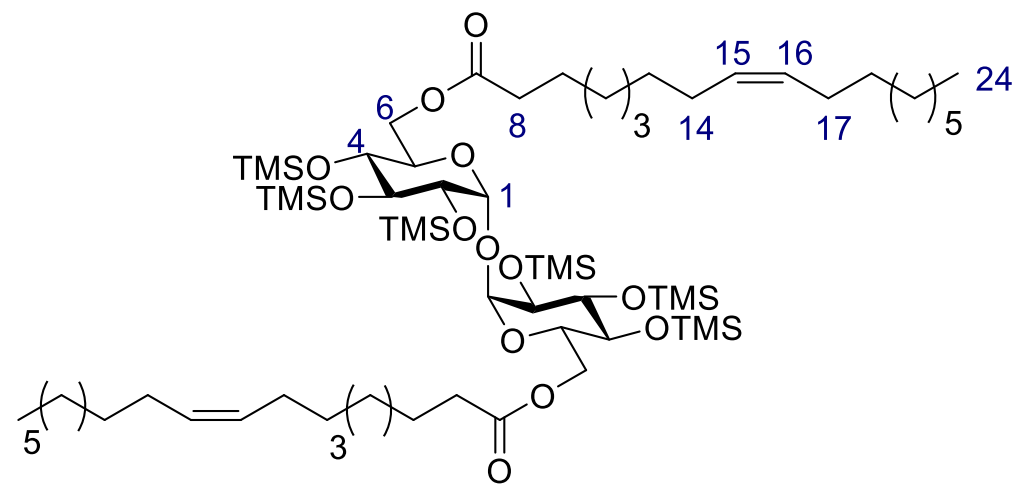

\begin{abstract}
$2,2^{\prime}, 3,3 ', 4,4^{\prime}-$ Hexa- $O$-trimethylsilyl6,6'-di- $O$-oleoyl- $\alpha, \alpha^{\prime}$-trehalose (27c). Diol 25 (306 mg, $0.39 \mathrm{mmol}$ ), oleic acid (0.63 mL, $2.0 \mathrm{mmol})$, EDCI (491 mg, $2.6 \mathrm{mmol}$ ) and DMAP (97 mg, $0.80 \mathrm{mmol}$ ) were subjected to the general procedure for esterification
\end{abstract} reactions. The crude product was purified by silica gel flash column chromatography (petroleum ether to petroleum ether:EtOAc, $95: 15, v / v)$ to give the title compound as a colourless oil (422 $\mathrm{mg}, 0.32$ 
mmol, 82\%). $\mathrm{R}_{f}=0.51$ (petroleum ether:EtOAc, 9:1, v/v); $[\alpha]_{\mathrm{D}}^{21}=+69\left(c=1.0, \mathrm{CH}_{2} \mathrm{Cl}_{2}\right) ; \mathrm{IR}($ film) 2924, 2854, 1741, 1458, 1250, 1164, 1110, 1099, 1075, 1045, 1008, 965, 897, 870, $837 \mathrm{~cm}^{-1}$; ${ }^{1} \mathrm{H}-\mathrm{NMR}$ $\left(500 \mathrm{MHz}, \mathrm{CDCl}_{3}\right) \delta 5.34\left(\mathrm{dt}, J_{15,16}=7.1 \mathrm{~Hz}, J_{14,15}=J_{16,17}=3.0 \mathrm{~Hz}, 4 \mathrm{H}, \mathrm{H}-15 \& \mathrm{H}-16\right), 4.92\left(\mathrm{~d}, J_{1,2}\right.$ $=3.0 \mathrm{~Hz}, 2 \mathrm{H}, \mathrm{H}-1), 4.27\left(\mathrm{dd}, J_{6 \mathrm{a}, 6 \mathrm{~b}}=11.9 \mathrm{~Hz}, J_{5,6 \mathrm{a}}=2.2 \mathrm{~Hz}, 2 \mathrm{H}, \mathrm{H}-6 \mathrm{a}\right), 4.05\left(\mathrm{dd}, J_{6 \mathrm{a}, 6 \mathrm{~b}}=11.8 \mathrm{~Hz}, J_{5,6 \mathrm{~b}}\right.$ $=4.3 \mathrm{~Hz}, 2 \mathrm{H}, \mathrm{H}-6 \mathrm{~b}), 4.00\left(\mathrm{ddd}, J_{4,5}=9.4 \mathrm{~Hz}, J_{5,6 \mathrm{~b}}=4.3 \mathrm{~Hz}, J_{5,6 \mathrm{a}}=2.1 \mathrm{~Hz}, 2 \mathrm{H}, \mathrm{H}-5\right), 3.90\left(\mathrm{t}, J_{2,3}=J_{3,4}\right.$ $=8.9 \mathrm{~Hz}, 2 \mathrm{H}, \mathrm{H}-3), 3.48\left(\mathrm{t}, J_{3,4}=J_{4,5}=9.0 \mathrm{~Hz}, 2 \mathrm{H}, \mathrm{H}-4\right), 3.22\left(\mathrm{dd}, J_{2,3}=9.3 \mathrm{~Hz}, J_{1,2}=3.1 \mathrm{~Hz}, 2 \mathrm{H}, \mathrm{H}-\right.$ 2), 2.34 (m, 4H, H-8), 2.00 (m, 4H, H-14 \& H-17), 1.63 (m, 4H, H-9), 1.37-1.22 (m, 40H, H-10-H-13 \& H-18-H-23), 0.88 (t, J J3,24 $=7.0 \mathrm{~Hz}, 6 \mathrm{H}, \mathrm{H}-24), 0.15,0.13,0.13$ (3 s, 54H, $\left.\mathrm{CH}_{3} \mathrm{TMS}\right) ;{ }^{13} \mathrm{C}-\mathrm{NMR}$ $\left(125 \mathrm{MHz}, \mathrm{CDCl}_{3}\right) \delta 173.9(\mathrm{C}=\mathrm{O}), 130.1,129.9$ (C-15 \& C-16), 94.6 (C-1), 73.6 (C-3), 72.3 (C-2), 72.1 (C-4), 70.9 (C-5), 63.5 (C-6), 34.3 (C-8), 32.1, 29.92, 29.88, 29.7, 29.5, 29.4, 29.3. 27.4, 22.8 (C10-C-3 \& C-18-C-23), 27.3 (C-14 \& C-17), 24.9 (C-9), 14.3 (C-24), 1.22, 1.04, 0.34 (TMS); HRMS (ESI) $\mathrm{m} / z,\left[\mathrm{M}+\mathrm{NH}_{4}\right]^{+}$calcd. for $\left[\mathrm{C}_{66} \mathrm{H}_{134} \mathrm{O}_{13} \mathrm{Si}_{6}+\mathrm{NH}_{4}\right]^{+}: 1320.8778$, obsd. 1320.8751.

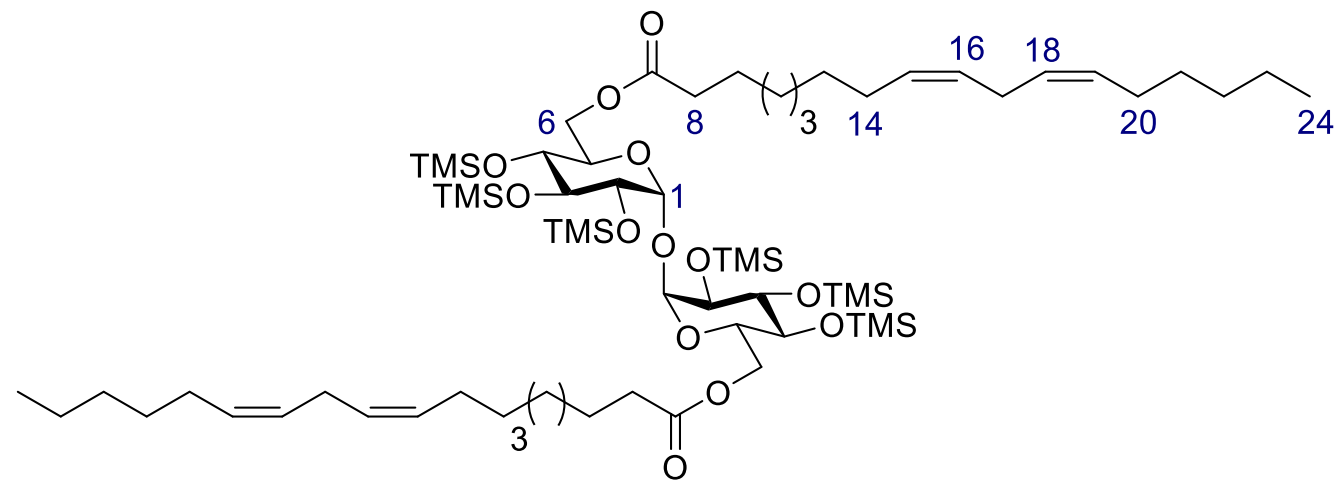

2,2',3,3',4,4'-Hexa- $\boldsymbol{O}$-trimethylsilyl-6,6'-di- $\boldsymbol{O}$-lineoyl- $\boldsymbol{\alpha}, \boldsymbol{\alpha}^{\prime}$-trehalose (27d). Diol 25 (305 mg, 0.39 mmol), linoleic acid (0.61 mL, $2.0 \mathrm{mmol})$, EDCI (490 mg, $2.6 \mathrm{mmol})$ and DMAP (97 mg, $0.80 \mathrm{mmol})$ were subject to the general procedure for esterification reactions. The crude product was purified by silica gel flash column chromatography (petroleum ether to petroleum ether:EtOAc, 95:5, v/v) to give the title compound as a colourless oil $(328 \mathrm{mg}, 0.25 \mathrm{mmol}, 64 \%) . \mathrm{R}_{f}=0.53$ (petroleum ether:EtOAc, 9:1, v/v); $[\alpha]_{\mathrm{D}}^{20}=+67\left(c=1.0, \mathrm{CH}_{2} \mathrm{Cl}_{2}\right) ; \mathrm{IR}$ (film) 3009, 2955, 2926, 2855, 1741, 1458, 1250, 1163 , 1110, 1099, 1075, 1045, 1009, 964, 897, 870, $837 \mathrm{~cm}^{-1} ;{ }^{1} \mathrm{H}-\mathrm{NMR}\left(500 \mathrm{MHz}, \mathrm{CDCl}_{3}\right) \delta 5.44-5.26(\mathrm{~m}$, $8 \mathrm{H}, \mathrm{H}-15-\mathrm{H}-16$ \& H-18-H-19), 4.92 (d, $\left.J_{1,2}=3.0 \mathrm{~Hz}, 2 \mathrm{H}, \mathrm{H}-1\right), 4.27$ (dd, $J_{6 \mathrm{a}, 6 \mathrm{~b}}=11.9 \mathrm{~Hz}, J_{5,6 \mathrm{a}}=2.0$ $\mathrm{Hz}, 2 \mathrm{H}, \mathrm{H}-6 \mathrm{a}), 4.06\left(\mathrm{dd}, J_{6 \mathrm{a}, 6 \mathrm{~b}}=11.9 \mathrm{~Hz}, J_{5,6 \mathrm{~b}}=4.4 \mathrm{~Hz}, 2 \mathrm{H}, \mathrm{H}-6 \mathrm{~b}\right), 4.00\left(\mathrm{ddd}, J_{4,5}=9.1 \mathrm{~Hz}, J_{5,6 \mathrm{~b}}=3.9\right.$ $\left.\mathrm{Hz}, J_{5,6 \mathrm{a}}=1.9 \mathrm{~Hz}, 2 \mathrm{H}, \mathrm{H}-5\right), 3.90\left(\mathrm{t}, J_{2,3}=J_{3,4}=8.9 \mathrm{~Hz}, 2 \mathrm{H}, \mathrm{H}-3\right), 3.48\left(\mathrm{t}, J_{3,4}=J_{4,5}=9.0 \mathrm{~Hz}, 2 \mathrm{H}, \mathrm{H}-\right.$ 4), $3.44\left(\mathrm{dd}, J_{2,3}=9.2 \mathrm{~Hz}, J_{1,2}=3.0 \mathrm{~Hz}, 2 \mathrm{H}, \mathrm{H}-2\right), 2.77$ (t, $\left.J_{16,17}=J_{17,18}=6.6 \mathrm{~Hz}, 4 \mathrm{H}, \mathrm{H}-17\right), 2.33(\mathrm{~m}$, $4 \mathrm{H}, \mathrm{H}-8), 2.05\left(\mathrm{q}, J_{13,14}=J_{14,15}=J_{19,20}=J_{20,21}=6.7 \mathrm{~Hz}, 8 \mathrm{H}, \mathrm{H}-14 \& \mathrm{H}-20\right), 1.63$ (m, 4H, H-9), $1.47-$ 1.23 (m, 28H, H-10-H-13 \& H-20-H-23), 0.89 (t, J23,24 = 6.9 Hz, 6H, H-24), 0.15, 0.13, 0.13 (3 s, 54H, $\left.\mathrm{CH}_{3} \mathrm{TMS}\right) ;{ }^{13} \mathrm{C}-\mathrm{NMR}\left(125 \mathrm{MHz}, \mathrm{CDCl}_{3}\right) \delta 173.9(\mathrm{C}=\mathrm{O}), 130.4,130.2,128.2,128.0(\mathrm{C}-15-\mathrm{C}-16$ \& $\mathrm{C}-$ 
18-C-19), 94.6 (C-1), 73.6 (C-3), 72.8 (C-2), 72.0 (C-4), 70.9 (C-5), 63.5 (C-6), 34.3 (C-8), 31.7, 29.8, 29.5, 29.4, 29.3, 27.6 (C-10-C-13 \& C-20-C-23), 25.8 (C-14 \& C-20), 24.9 (C-17), 22.7 (C-9), 14.3 (C-24), 1.2, 1.0, 0.3 (TMS); HRMS (ESI) $m / z .\left[\mathrm{M}+\mathrm{NH}_{4}\right]^{+}$calcd. for: $\left[\mathrm{C}_{66} \mathrm{H}_{130} \mathrm{O}_{13} \mathrm{Si}_{6}+\mathrm{NH}_{4}\right]^{+}$: 1316.8465, obsd. 1316.8497.

General procedure for desilylation. The $\mathrm{pH}$ of a solution of trehalose diester $\mathbf{2 7 a}-\mathbf{d}(0.03 \mathrm{mmol} / \mathrm{mL})$ in $\mathrm{CH}_{2} \mathrm{Cl}_{2}: \mathrm{MeOH}(1: 1, v / v)$ was adjusted to $\mathrm{pH}=4-2$ with Dowex $-\mathrm{H}^{+}$resin and the mixture stood until the reaction was complete by TLC $(0.5-2$ hours $)$. The solution was then filtered, washing the resin thoroughly with $\mathrm{CH}_{2} \mathrm{Cl}_{2}: \mathrm{MeOH}(1: 1, v / v)$, and concentrated. The resultant residue was purified as detailed in each individual procedure.

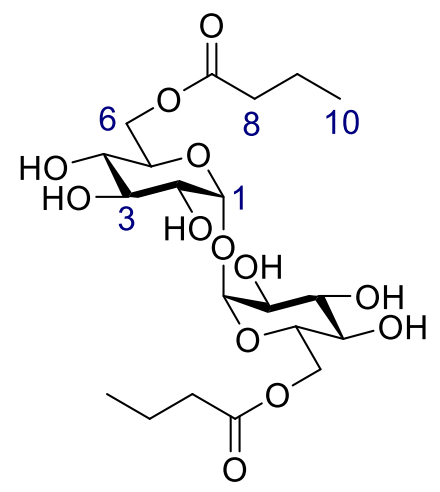

6,6'-Di- $\boldsymbol{O}$-butanoyl- $\boldsymbol{\alpha}, \boldsymbol{\alpha}^{\prime}$-trehalose (24a). Di-ester 27a (192 mg, 0.21 mmol) was subjected to the general procedure for desilylation. The crude product was purified by gradient silica gel flash column chromatography (EtOAc to EtOAc:MeOH, 9:1, v/v) to give the title compound as a white solid (75 mg, $0.16 \mathrm{mmol}, 74 \%) \mathrm{R}_{f}=0.32\left(\right.$ EtOAc:MeOH, 9:1, v/v); $[\alpha]_{\mathrm{D}}^{23}$ $=+135(c=1.0, \mathrm{MeOH})$; IR (film) 3329, 2935, 1726, 1456, 1418, 1351, $1307,1254,1179,1151,1106,1076,1057,1040,1018,982,934,915 \mathrm{~cm}^{-}$

${ }^{1},{ }^{1} \mathrm{H}-\mathrm{NMR}\left(500 \mathrm{MHz}, \mathrm{CD}_{3} \mathrm{OD}\right) \delta 5.02\left(\mathrm{~d}, J_{1,2}=3.8 \mathrm{~Hz}, 2 \mathrm{H}, \mathrm{H}-1\right), 4.34\left(\mathrm{dd}, J_{6 \mathrm{a}, 6 \mathrm{~b}}=11.9 \mathrm{~Hz}, J_{5,6 \mathrm{a}}=\right.$ $2.1 \mathrm{~Hz}, 2 \mathrm{H}, \mathrm{H}-6 \mathrm{a}), 4.18\left(\mathrm{dd}, J_{6 \mathrm{a}, 6 \mathrm{~b}}=11.9 \mathrm{~Hz}, J_{5,6 \mathrm{~b}}=5.1 \mathrm{~Hz}, 2 \mathrm{H}, \mathrm{H}-6 \mathrm{~b}\right), 3.99$ (ddd, $J_{4,5}=10.1 \mathrm{~Hz}, J_{5,6 \mathrm{~b}}$ $\left.=5.1 \mathrm{~Hz}, J_{5,6 \mathrm{a}}=2.2 \mathrm{~Hz}, 2 \mathrm{H}, \mathrm{H}-5\right), 3.75\left(\mathrm{t}, J_{2,3}=J_{3,4}=9.2 \mathrm{~Hz}, 2 \mathrm{H}, \mathrm{H}-3\right), 3.44\left(\mathrm{dd}, J_{2,3}=9.7 \mathrm{~Hz}, J_{1,2}=\right.$ $3.8 \mathrm{~Hz}, 2 \mathrm{H}, \mathrm{H}-2), 3.32\left(\mathrm{t}, J_{3,4}=J_{4,5}=8.9 \mathrm{~Hz}, 2 \mathrm{H}, \mathrm{H}-4\right), 2.31\left(\mathrm{t}, J_{7,8}=7.3 \mathrm{~Hz}, 4 \mathrm{H}, \mathrm{H}-8\right), 1.63\left(\mathrm{~h}, J_{8,9}=\right.$ $\left.J_{9,10}=7.4 \mathrm{~Hz}, 4 \mathrm{H}, \mathrm{H}-9\right), 0.94\left(\mathrm{t}, J_{9,10}=7.5 \mathrm{~Hz}, 6 \mathrm{H}, \mathrm{H}-10\right) ;{ }^{13} \mathrm{C}-\mathrm{NMR}\left(125 \mathrm{MHz}, \mathrm{CD}_{3} \mathrm{OD}\right) \delta 175.3$ (C=O), 95.3 (C-1), 74.5 (C-3), 73.1 (C-2), 71.9 (C-4), 71.5 (C-5), 64.3 (C-6), 36.9 (C-8), 19.5 (C-9), 14.0 (C-10); HRMS (ESI) $m / z\left[\mathrm{M}+\mathrm{NH}_{4}\right]^{+}$calcd. for $\left[\mathrm{C}_{20} \mathrm{H}_{34} \mathrm{O}_{13}+\mathrm{NH}_{4}\right]^{+}:$500.2338, obsd.: 500.2332.

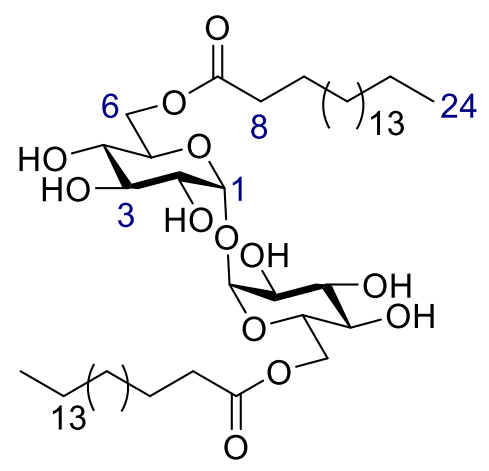

6,6'-Di- $\boldsymbol{O}$-stearoyl- $\boldsymbol{\alpha}, \boldsymbol{\alpha}$ '-trehalose (24b). Di-ester 27b (370 mg, 0.28 mmol) was subjected to the general procedure for desilylation. The crude product was purified by gradient silica gel flash column chromatography (EtOAc to EtOAc: $\mathrm{MeOH}, 9: 1, v / v$ ) to give the title compound as a white solid (39 mg, $0.05 \mathrm{mmol}, 16 \%) . \mathrm{R}_{f}=0.41$ (EtOAc: $\mathrm{MeOH}, 9: 1, v / v) ;[\alpha]_{\mathrm{D}}^{21}=+88(c=0.3$, pyridine) ; IR (film) 3357, 2916, 2849, 1736, 1466, 1415, 1356, 1150, 1100, 1075, 1051, 1019, 988, 939, 910, $807 \mathrm{~cm}^{-1}$; ${ }^{1} \mathrm{H}-\mathrm{NMR}\left(500 \mathrm{MHz}, \mathrm{C}_{5} \mathrm{D}_{5} \mathrm{~N}\right) \delta 5.92\left(\mathrm{~d}, J_{1,2}=3.7 \mathrm{~Hz}, 2 \mathrm{H}, \mathrm{H}-1\right), 5.12$ $\left(\mathrm{ddd}, J_{4,5}=10.2 \mathrm{~Hz}, J_{5,6 \mathrm{~b}}=5.3 \mathrm{~Hz}, J_{5,6 \mathrm{a}}=1.8 \mathrm{~Hz}, 2 \mathrm{H}, \mathrm{H}-5\right), 4.86\left(\mathrm{dd}, J_{6 \mathrm{a}, 6 \mathrm{~b}}=11.7, J_{5,6 \mathrm{a}}=2.0 \mathrm{~Hz}, 2 \mathrm{H}\right.$, 
H-6a), $4.86\left(\mathrm{dd}, J_{6 \mathrm{a}, 6 \mathrm{~b}}=11.7 \mathrm{~Hz}, J_{5,6 \mathrm{~b}}=5.5 \mathrm{~Hz}, 2 \mathrm{H}, \mathrm{H}-6 \mathrm{~b}\right), 4.78\left(\mathrm{t}, J_{2,3}=J_{3,4}=9.2 \mathrm{~Hz}, 2 \mathrm{H}, \mathrm{H}-3\right), 4.34$ $\left(\mathrm{dd}, J_{2,3}=9.5 \mathrm{~Hz}, J_{1,2}=3.5 \mathrm{~Hz}, 2 \mathrm{H}, \mathrm{H}-2\right), 4.20$ (t, $\left.J_{3,4}=J_{4,5}=9.5 \mathrm{~Hz}, 2 \mathrm{H}, \mathrm{H}-4\right), 2.32$ (m, 4H, H-8), $1.63\left(\mathrm{p}, J_{8.9}=J_{9,10}=7.4 \mathrm{~Hz}, 4 \mathrm{H}, \mathrm{H}-9\right), 1.35-1.10(\mathrm{~m}, 56 \mathrm{H}, \mathrm{H}-10-\mathrm{H}-23), 0.88\left(\mathrm{t}, J_{23,24}=6.7 \mathrm{~Hz}, 6 \mathrm{H}\right.$, $\mathrm{H}-24) ;{ }^{13} \mathrm{C}-\mathrm{NMR}\left(125 \mathrm{MHz}, \mathrm{C}_{5} \mathrm{D}_{5} \mathrm{~N}\right) \delta 174.2(\mathrm{C}=\mathrm{O}), 96.3(\mathrm{C}-1), 75.4$ (C-3), 73.9 (C-2), 72.5 (C-4), 72.1 (C-5), 64.9 (C-6), 32.6, 30.51, 30.49, 30.48, 30.46, 30.42, 30.26, 30.11, 30.07, 23.43 (C-10 - C23), 25.8 (C-9), 14.8 (C-24), HRMS (ESI) $\mathrm{m} / z$ [M+NH$]^{+}$calcd. for $\left[\mathrm{C}_{48} \mathrm{H}_{90} \mathrm{O}_{13}+\mathrm{NH}_{4}\right]^{+}: 892.6720$, obsd. 892.6721.

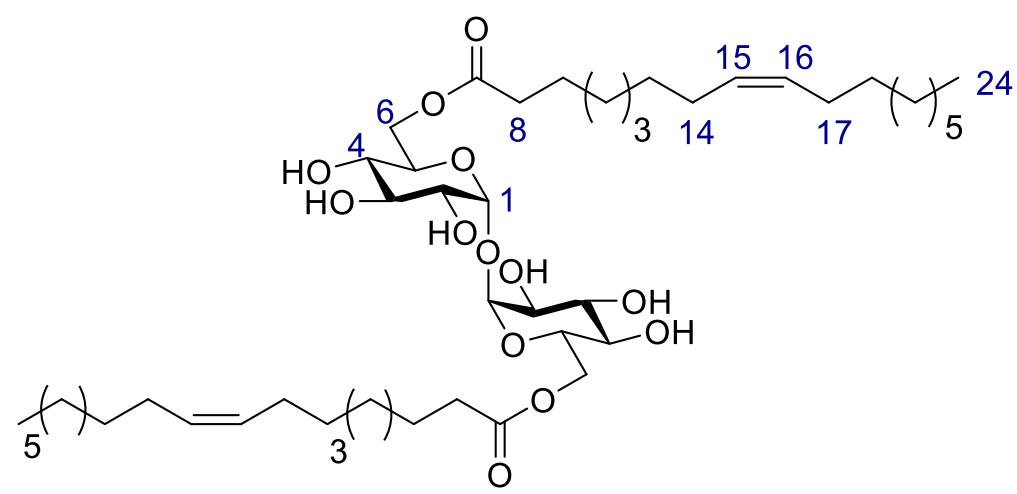

6,6'-Di-oleoyl- $\alpha, \alpha^{\prime}$-trehalose (24c).

Di-ester 27c (345 mg, $0.26 \mathrm{mmol}$ ) was subjected to the general procedure for desilylation. The crude product was purified by gradient silica gel flash column chromatography (EtOAc to EtOAc: $\mathrm{MeOH}, 9: 1, v / v$ ) to give the title compound as a white solid (195 mg, $0.22 \mathrm{mmol}, 85 \%)$. $\mathrm{R}_{f}=0.49($ EtOAc:MeOH, 9:1, $v / v) ;[\alpha]_{\mathrm{D}}^{22}=$ +83 ( $c=1.0$, pyridine) ; IR (film) 3332, 3007, 2922, 2852, 1728, 1455, 1377, 1351, 1278, 1247, 1152, 1103, 1081, 1061, 1016, 983, 937, $911 \mathrm{~cm}^{-1} ;{ }^{1} \mathrm{H}-\mathrm{NMR}\left(500 \mathrm{MHz}, \mathrm{C}_{5} \mathrm{D}_{5} \mathrm{~N}\right) \delta 5.91\left(\mathrm{~d}, J_{1,2}=3.6 \mathrm{~Hz}, 2 \mathrm{H}\right.$, $\mathrm{H}-1), 5.57-5.43$ (m, 4H, H-15-H-16), $5.11\left(\mathrm{ddd}, J_{4,5}=10.2 \mathrm{~Hz}, J_{5,6 \mathrm{~b}}=5.3 \mathrm{~Hz}, J_{5,6 \mathrm{a}}=2.0 \mathrm{~Hz}, 2 \mathrm{H}, \mathrm{H}-5\right)$, $5.01 \mathrm{dd}\left(J_{6 \mathrm{a}, 6 \mathrm{~b}}=11.6 \mathrm{~Hz}, J_{5,6 \mathrm{a}}=2.2 \mathrm{~Hz}, 2 \mathrm{H}, \mathrm{H}-6 \mathrm{a}\right), 4.85\left(\mathrm{dd}, J_{6 \mathrm{a}, 6 \mathrm{~b}}=11.8 \mathrm{~Hz}, J_{5,6 \mathrm{~b}}=5.5 \mathrm{~Hz}, 2 \mathrm{H}, \mathrm{H}-\right.$ $6 \mathrm{~b}), 4.77\left(\mathrm{t}, J_{2,3}=\mathrm{J}_{3,4}=9.2 \mathrm{~Hz}, 2 \mathrm{H}, \mathrm{H}-3\right), 4.33\left(\mathrm{dd}, J_{2,3}=9.6 \mathrm{~Hz}, J_{1,2}=3.7 \mathrm{~Hz}, 2 \mathrm{H}, \mathrm{H}-2\right), 4.19\left(\mathrm{t}, J_{3,4}\right.$ $\left.=J_{4,5}=9.8 \mathrm{~Hz}, 2 \mathrm{H}, \mathrm{H}-4\right), 2.37(\mathrm{~m}, 4 \mathrm{H}, \mathrm{H}-8), 2.17-2.40(\mathrm{~m}, 8 \mathrm{H}, \mathrm{H}-14 \& \mathrm{H}-17), 1.63\left(\mathrm{p}, J_{8,9}=J_{9,10}=\right.$ $7.2 \mathrm{~Hz}, 4 \mathrm{H}, \mathrm{H}-9), 1.44-1.08$ (m, 40 H, H-10-H-13 \& H-18-H-23), 0.85 (m, 6H, H-24); ${ }^{13} \mathrm{C}-\mathrm{NMR}$ (125 $\left.\mathrm{MHz}, \mathrm{C}_{5} \mathrm{D}_{5} \mathrm{~N}\right) \delta 174.1(\mathrm{C}=\mathrm{O}), 130.7$ (C-15 \& C-16), 96.3 (C-1), 75.4 (C-3), 73.9 (C-2), 72.5 (C-4), 72.1 (C-5), 64.9 (C-6), 34.7 (C-8), 32.6, 30.6, 30.5, 30.3, 30.1 , 30.03, 29.95, 29.85, 29.82, 28.00, 25.7 (C-10-C-13 \& C-18-C-23), C-27.99 (C-14 \& C-17), 23.4 (C-9), 14.8 (C-24); HRMS (ESI) m/z $\left[\mathrm{M}+\mathrm{NH}_{4}\right]^{+}$calcd. for $\left[\mathrm{C}_{84} \mathrm{H}_{86} \mathrm{O}_{13}+\mathrm{NH}_{4}\right]^{+}:$888.6407, obsd. 888.6401. 


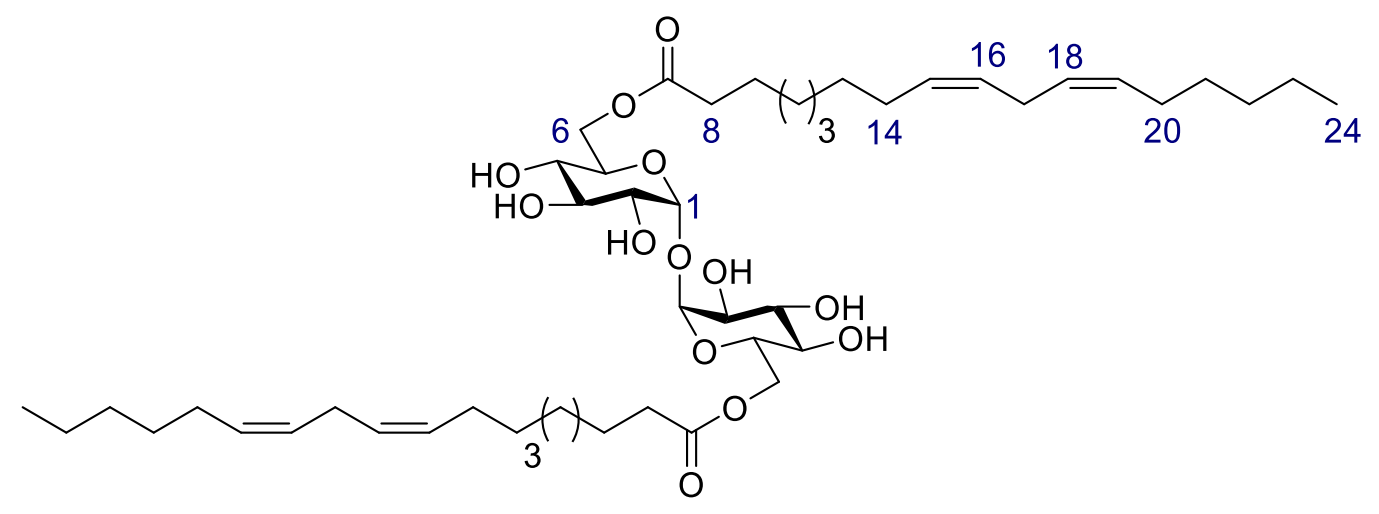

6,6'-Di-lineoyl- $\boldsymbol{\alpha}, \boldsymbol{\alpha}^{\prime}$-trehalose (24d). Di-ester 27d (252 mg, $\left.0.19 \mathrm{mmol}\right)$ was subjected to the general procedure for desilylation. The crude product was purified by gradient silica gel flash column chromatography (EtOAc to EtOAc:MeOH, 9:1, v/v) to give the title compound as a white solid (148 mg, 0.17 mmol, 88\%). $\mathrm{R}_{f}=0.66$ (EtOAc:MeOH, 9:1, v/v); $[\alpha]_{\mathrm{D}}^{22}=+70(c=1.0$, pyridine) ; IR (film) 3325, 3009, 2923, 2854, 1729, 1455, 1376, 1352, 1275, 1246, 1151, 1115, 1103, 1081, 1060, 1051, 983, 937, 911, $807 \mathrm{~cm}^{-1} ;{ }^{1} \mathrm{H}-\mathrm{NMR}\left(500 \mathrm{MHz}, \mathrm{C}_{5} \mathrm{D}_{5} \mathrm{~N}\right) \delta 5.91\left(\mathrm{~d}, J_{1,2}=3.7 \mathrm{~Hz}, 2 \mathrm{H}, \mathrm{H}-1\right), 5.55-5.46(\mathrm{~m}$, $8 \mathrm{H}, \mathrm{H}-15-\mathrm{H}-16 \& \mathrm{H}-18-\mathrm{H}-19), 5.11\left(\mathrm{ddd}, J_{4,5}=9.9 \mathrm{~Hz}, J_{5,6 \mathrm{~b}}=5.3 \mathrm{~Hz}, J_{5,6 \mathrm{a}}=2.0 \mathrm{~Hz}, 2 \mathrm{H}, \mathrm{H}-5\right), 5.01$ $\left(\mathrm{dd}, J_{6 \mathrm{a}, 6 \mathrm{~b}}=11.8 \mathrm{~Hz}, J_{5,6 \mathrm{a}}=2.2 \mathrm{~Hz}, 2 \mathrm{H}, \mathrm{H}-6 \mathrm{a}\right) ; 4.85\left(\mathrm{dd}, J_{6 \mathrm{a}, 6 \mathrm{~b}}=11.8 \mathrm{~Hz}, J_{5,6 \mathrm{~b}}=5.3 \mathrm{~Hz}, 2 \mathrm{H}, \mathrm{H}-6 \mathrm{~b}\right)$, $4.77\left(\mathrm{t}, J_{2,3}=J_{3,4}=9.1 \mathrm{~Hz}, 2 \mathrm{H}, \mathrm{H}-3\right) ; 4.33\left(\mathrm{dd}, J_{2,3}=9.6 \mathrm{~Hz}, J_{1,2}=3.6 \mathrm{~Hz}, 2 \mathrm{H}, \mathrm{H}-2\right), 4.20\left(\mathrm{t}, J_{3,4}=J_{4,5}\right.$ $=9.5 \mathrm{~Hz}, 2 \mathrm{H}, \mathrm{H}-4), 2.93\left(\mathrm{t}, J_{16,17}=J_{17.18}=5.7 \mathrm{~Hz}, 4 \mathrm{H}, \mathrm{H}-17\right), 2.33(\mathrm{~m}, 4 \mathrm{H}, \mathrm{H}-8), 2.11$ (p, $J_{13,14}=J_{14,15}$ $\left.=J_{19,20}=J_{20,21}=7.1 \mathrm{~Hz}, 8 \mathrm{H}, \mathrm{H}-14 \& \mathrm{H}-20\right), 1.62\left(\mathrm{p}, J_{8,9}=J_{9,10}=7.4 \mathrm{~Hz}, 4 \mathrm{H}, \mathrm{H}-9\right), 1.39-1.13(\mathrm{~m}, 26$ $\mathrm{H}, \mathrm{H}-10-\mathrm{H}-13 \& \mathrm{H}-21-\mathrm{H}-23), 0.87\left(\mathrm{t}, J_{23,24}=7.0 \mathrm{~Hz}, 6 \mathrm{H}, \mathrm{H}-24\right) ;{ }^{13} \mathrm{C}-\mathrm{NMR}\left(125 \mathrm{MHz}, \mathrm{C}_{5} \mathrm{D}_{5} \mathrm{~N}_{5}\right) \delta$ $174.1(\mathrm{C}=\mathrm{O}), 130.9,128.9$ (C-15-C-16 \& C-18-19), 96.3 (C-1), 75.3 (C-4), 73.9 (C-2), 72.5 (C-3), 72.1 (C-5), 64.9 (C-6), 34.9 (C-8), 32.2, 30.4, 30.1, 30.0, 29.8, 27.95, 23.3 (C-10-13 \& C-21-23), 27.95 (C-14 \& C-20), 26.5 (C-17), 25.7 (C-9), 14.7 (C-24); HRMS (ESI) m/z [M+NH4] $]^{+}$calcd. for $\left[\mathrm{C}_{48} \mathrm{H}_{82} \mathrm{O}_{13}+\mathrm{NH}_{4}\right]^{+}$: 884.6094, obsd.: 884.6107.

Methyl 2,4-dihydroxybenzoate (30b). To a stirred solution of 2,4-dihydroxybenzoic
solution was then refluxed for 20 hours. The mixture was concentrated, diluted with water $(20 \mathrm{~mL})$ and extracted with $\mathrm{CH}_{2} \mathrm{Cl}_{2}(3 \times 50 \mathrm{~mL})$. The combined organic layers were washed with brine $(3 \times 250 \mathrm{~mL})$, dried $\left(\mathrm{MgSO}_{4}\right)$, filtered and concentrated to give the title compound as an off-white solid (3.59 g, $21.4 \mathrm{mmol}, 66 \%) . \mathrm{R}_{f}=0.53\left(\mathrm{CH}_{2} \mathrm{Cl}_{2}\right.$ :EtOAc, 9:1, v/v); IR (film) 3335, 3179, 2957, 2957, 2917, 2849, 1637, 1615, 1599, 1504, 1434, 1414, 1356, 1333, 1265, 1173, 1145, 1095, 978, 945, $876 \mathrm{~cm}^{-1} ;{ }^{1} \mathrm{H}-\mathrm{NMR}\left(500 \mathrm{MHz}, \mathrm{CDCl}_{3}\right) \delta 10.97(\mathrm{~s}, 1 \mathrm{H}, 2-\mathrm{OH}), 7.73\left(\mathrm{~d}, J_{5,6}=8.6 \mathrm{~Hz}, 1 \mathrm{H}\right)$, 
$6.40\left(\mathrm{~d}, J_{3,5}=2.4 \mathrm{~Hz}, 1 \mathrm{H}, \mathrm{H}-3\right), 6.37\left(\mathrm{dd}, J_{5,6}=8.7 \mathrm{~Hz}, J_{3,5}=2.6 \mathrm{~Hz}, 1 \mathrm{H}, \mathrm{H}-5\right), 5.43\left(\mathrm{~s}, 3 \mathrm{H}, \mathrm{CO}_{2} \mathrm{Me}\right)$;

${ }^{13} \mathrm{C}-\mathrm{NMR}\left(125 \mathrm{MHz}, \mathrm{CDCl}_{3}\right) \delta 170.5$ (C=O), 163.8 (C-4), 162.0 (C-2). $132.0(\mathrm{C}-6), 107.9(\mathrm{C}-3), 106.1$ (C-1), 103.3 (C-5), $52.2\left(\mathrm{CO}_{2} \mathrm{Me}\right)$; HRMS (ESI) $\mathrm{m} / z[\mathrm{M}+\mathrm{H}]^{+}$calcd. for $\left[\mathrm{C}_{8} \mathrm{H}_{8} \mathrm{O}_{4}+\mathrm{H}\right]^{+}:$169.0495, obsd.: 169.0497.

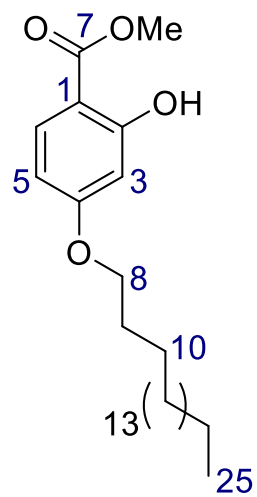

Methyl 4-(octadecyloxy)-2-hydroxybenzoate (32). To a stirred solution of methyl 2,4-dihydroxybenzoate 30b $(3.03 \mathrm{~g}, 18 \mathrm{mmol})$ in distilled acetone $(120 \mathrm{~mL})$ was added $\mathrm{K}_{2} \mathrm{CO}_{3}$ (4.98 g, $36 \mathrm{mmol}$ ), 1-bromooctadecane (9.03 g, $27 \mathrm{mmol}$ ) and TBAI (665 $\mathrm{mg}, 1.8 \mathrm{mmol}$ ). The reaction mixture was refluxed for 20 hours and then concentrated. Purification of the residue by gradient silica gel flash chromatography (petroleum ether to petroleum ether:EtOAc, 9:1, v/v) gave the title compound as an off-white solid (7.04 g, $17 \mathrm{mmol}, 93 \%)$. $\mathbf{R}_{f}=0.79$ (petroleum ether:EtOAc, 4:1, v/v); IR (film) 3216, 2915, 2847, 1675, 1619, 1577, 1503, 1469, 1444, 1395, 1356, 1333 , 1249, 1203, 1182, 1135, 1089, 1032, 1020, 990, 952, $840 \mathrm{~cm}^{-1} ;{ }^{1} \mathrm{H}-\mathrm{NMR}\left(500 \mathrm{MHz}, \mathrm{CDCl}_{3}\right) \delta 10.96$ $(\mathrm{s}, 1 \mathrm{H}, \mathrm{OH}), 7.72\left(\mathrm{dd}, J_{5,6}=7.1 \mathrm{~Hz}, J_{3,6}=2.2 \mathrm{~Hz}, 1 \mathrm{H}, \mathrm{H}-6\right), 6.56-6.28(\mathrm{~m}, 2 \mathrm{H}, \mathrm{H}-3$ \& H-5), 3.96 (t, $\left.J_{7,8}=6.5 \mathrm{~Hz}, 2 \mathrm{H}, \mathrm{H}-8\right), 3.91\left(\mathrm{~s}, 3 \mathrm{H}, \mathrm{CO}_{2} \mathrm{Me}\right), 1.77\left(\mathrm{p}, J_{8,9}=J_{9,10}=7.1 \mathrm{~Hz}, 2 \mathrm{H}, \mathrm{H}-9\right), 1.43\left(\mathrm{p}, J_{9,10}=\right.$ $\left.J_{10,11}=7.3 \mathrm{~Hz}, 2 \mathrm{H}, \mathrm{H}-10\right), 1.38-1.22(\mathrm{~m}, 28 \mathrm{H}, \mathrm{H}-11-\mathrm{H}-24), 0.88$ (t, $\left.J_{24,25}=7.1 \mathrm{~Hz}, 3 \mathrm{H}, \mathrm{H}-25\right) ;{ }^{13} \mathrm{C}-$ NMR (125 MHz, $\left.\mathrm{CDCl}_{3}\right) \delta 170.6(\mathrm{C}=\mathrm{O}), 165.4$ (C-4), 163.9 (C-2), 131.3 (C-6), 108.1 (C-5), 105.3 (C-1), 101.2 (C-3), 68.4 (C-8), $52.1\left(\mathrm{CO}_{2} \mathrm{Me}\right), 32.1,29.9,29.82,29.80,29.74,29.70,29.52,29.49$, 29.14 (C-11 - C-24), 29.10 (C-9), 22.9 (C-10), 14.3 (C-25); HRMS (ESI) $m / z[\mathrm{M}+\mathrm{H}]^{+}$calcd. for $\left[\mathrm{C}_{26} \mathrm{H}_{44} \mathrm{O}_{4}+\mathrm{H}\right]^{+}:$421.3312, obsd. 421.3315.

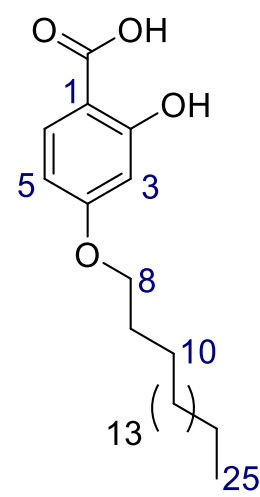

2-hydroxy-4-(octadecyloxy)benzoic acid (29b) To a suspension of benzoate 32 $(3.42 \mathrm{~g}, 8.1 \mathrm{mmol})$ in distilled methanol $(140 \mathrm{~mL})$ was added $5 \mathrm{M} \mathrm{NaOH}(18 \mathrm{~mL}, 90$ mmol) and the mixture refluxed for 20 hours. The methanol was removed in vacuo, the residue diluted with water $(350 \mathrm{~mL})$, acidified to $\mathrm{pH}=1$ with conc. $\mathrm{HCl}$ and extracted with EtOAc $(3 \times 300 \mathrm{~mL})$. The combined organic layers were diluted with pyridine $(50 \mathrm{~mL})$, dried $\left(\mathrm{MgSO}_{4}\right)$, filtered and concentrated to give a yellow-brown 25 solid. The solid was dissolved in hot EtOAc $(400 \mathrm{~mL})$, washed with brine $(300 \mathrm{~mL})$ and water $(300 \mathrm{~mL})$. The organic layer was dried $\left(\mathrm{MgSO}_{4}\right)$, filtered and concentrated to give the title compound as a pale peach solid $(3.17 \mathrm{~g}, 7.8 \mathrm{mmol}, 96 \%) . \mathrm{R}_{f}=0.34(4: 1$ petroleum ether:EtOAc $v / v)$; IR (film) 2915, 2849, 1669, 1646, 1622, 15578, 1508, 1471, 1376, 1273, 1241, 1197, 1176, 1155, 1102, 1031, 976, 888, $862 \mathrm{~cm}^{-1}$; ${ }^{1} \mathrm{H}-\mathrm{NMR}\left(500 \mathrm{MHz}, \mathrm{C}_{5} \mathrm{D}_{5} \mathrm{~N}\right) \delta 8.27$ (d, J5,6 $\left.=8.7 \mathrm{~Hz}, 1 \mathrm{H}, \mathrm{H}-6\right), 6.88$ $\left(\mathrm{d}, J_{3,5}=2.3 \mathrm{~Hz}, 1 \mathrm{H}, \mathrm{H}-3\right), 6.73\left(\mathrm{dd}, J_{5,6}=8.7 \mathrm{~Hz}, J_{3.5}=2.1 \mathrm{~Hz}, 1 \mathrm{H}, \mathrm{H}-5\right), 3.99$ (t, $J_{8,9}=6.5 \mathrm{~Hz}, 2 \mathrm{H}, \mathrm{H}-$ 
8), 1.75 (p, $\left.J_{8,9}=J_{9.10}=7.1 \mathrm{~Hz}, 2 \mathrm{H}, \mathrm{H}-9\right), 1.43$ (m, 2H, H-10), 1.38-1.17 (m, 28H, H-11 - H-24), 0.88 (t, $\left.J_{24,25}=7.0 \mathrm{~Hz}, 3 \mathrm{H}, \mathrm{H}-25\right) ;{ }^{13} \mathrm{C}-\mathrm{NMR}\left(125 \mathrm{MHz}, \mathrm{C}_{5} \mathrm{D}_{5} \mathrm{~N}\right) \delta 175.1(\mathrm{C}=\mathrm{O}), 165.5$ (C-4), 133.1 (C-6), 107.8 (C-5), 102.4 (C-3), 68.9 (C-8), 32.6, 30.51, 30.50, 30.47, 30.39, 30.36, 30.1, 29.9, 23.4 (C-9 \& C-11 - C-24), 26.9 (C-10), 14.8 (C-25); HRMS (ESI) $m / z[\mathrm{M}-\mathrm{H}]^{-}$calcd. for $\left[\mathrm{C}_{25} \mathrm{H}_{41} \mathrm{O}_{4}\right]^{-}: 405.3010$, obsd. 405.3021.

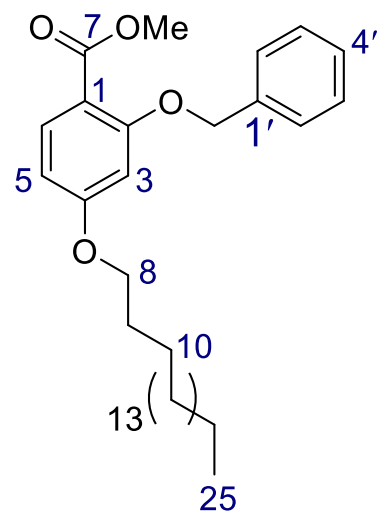

Methyl 2-(benzyloxy)-4-(octadecyloxy)benzoate (34) To a stirred suspension of benzoate $32(3.01 \mathrm{~g}, 7.2 \mathrm{mmol})$ in distilled acetone $(150 \mathrm{~mL})$ was added $\mathrm{K}_{2} \mathrm{CO}_{3}(2.03 \mathrm{~g}, 14.7 \mathrm{mmol}), \mathrm{BnBr}(1.7 \mathrm{~mL}, 14.3 \mathrm{mmol})$ and TBAI $(273 \mathrm{mg}, 0.7 \mathrm{mmol}$ ) and the mixture refluxed for 20 hours. Additional $\mathrm{BnBr}$ $(0.85 \mathrm{~mL}, 7.2 \mathrm{mmol})$ was added and the solution was stirred at reflux for a further 8 days. The mixture was cooled and concentrated and the resultant residue was purified by gradient silica gel flash column chromatography (petroleum ether to petroleum ether:EtOAc, 9:1, $v / v$ ) to give the title compound as a white solid (3.22 g, $6.3 \mathrm{mmol}, 88 \%) . \mathrm{R}_{f}=0.47$ (petroleum ether:EtOAc, 4:1, v/v); IR (film) 2914, 2849, 1726, 1608, 1574, 1504, 1469, 1453, 1428, 1377, 1301, 1258, 1208, 1185, 1156, 1088, 1039, 1028, $828 \mathrm{~cm}^{-1}$; ${ }^{1} \mathrm{H}-\mathrm{NMR}\left(500 \mathrm{MHz}, \mathrm{CDCl}_{3}\right) 7.87$ (d, J5,6 $\left.=8.8 \mathrm{~Hz}, 1 \mathrm{H}, \mathrm{H}-6\right), 7.52$ (d, $\left.J_{2^{\prime}, 3^{\prime}}=7.5 \mathrm{~Hz}, 2 \mathrm{H}, \mathrm{H}-2^{\prime}\right), 7.39$ (t, $\left.J_{2^{\prime}, 3^{\prime}}=J_{3^{\prime}, 4^{\prime}}=7.6 \mathrm{~Hz}, 2 \mathrm{H}, \mathrm{H}-3^{\prime}\right), 7.31$ (t, $\left.J_{3^{\prime}, 4^{\prime}}=7.4 \mathrm{~Hz}, 1 \mathrm{H}, \mathrm{H}^{-} 4^{\prime}\right)$, $6.52\left(\mathrm{~d}, J_{3,5}=2.2 \mathrm{~Hz}, 1 \mathrm{H}, \mathrm{H}-3\right), 6.50\left(\mathrm{dd}, J_{5,6}=8.7 \mathrm{~Hz}, J_{3,5}=2.3 \mathrm{~Hz}, 1 \mathrm{H}, \mathrm{H}-5\right), 5.16\left(\mathrm{~s}, 2 \mathrm{H}, \mathrm{CH}_{2}-O-\right.$ $\mathrm{Bn}$ ), 3.96 (t, $\left.J_{8,9}=6.6 \mathrm{~Hz}, 2 \mathrm{H}, \mathrm{H}-8\right), 3.87$ (s, 3H, $\mathrm{CO}_{2} \mathrm{Me}$ ), 1.76 (p, $\left.J_{8.9}=J_{9,10}=7.2 \mathrm{~Hz} \mathrm{H}-9\right), 1.48-1.15$ $(\mathrm{m}, 30 \mathrm{H}, \mathrm{H}-10-\mathrm{H}-24), 0.88\left(\mathrm{t}, J_{24,25}=6.8 \mathrm{~Hz}, 3 \mathrm{H}, \mathrm{H}-25\right) ;{ }^{13} \mathrm{C}-\mathrm{NMR}\left(125 \mathrm{MHz}, \mathrm{CDCl}_{3}\right) \delta 166.4$ (C=O), 163.9 (C-4), 160.4 (C-2), 136.9 (C-1'), 134.1 (C-6), 128.7 (C-2'), 127.9 (C-4'), 126.9 (C-3’), 112.7 (C-1), 105.9 (C-3), 101.1 (C-5), $70.7\left(\mathrm{CH}_{2}-\mathrm{O}-\mathrm{Bn}\right), 68.4$ (C-8), $51.8\left(\mathrm{CO}_{2} \mathrm{Me}\right), 32.08,29.9,29.84$. 29.82, 29.75, 29.7, 29.5, 29.3, 22.9 (C-10 - C-24), 26.1 (C-9), 14.3 (C-25); HRMS (ESI) m/z [M+H] ${ }^{+}$ calcd. for $\left[\mathrm{C}_{33} \mathrm{H}_{50} \mathrm{O}_{4}+\mathrm{H}\right]^{+}:$: 511.3782, obsd. 511.3782.

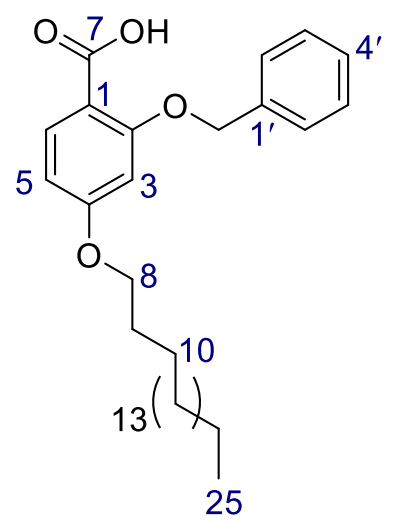

2-(Benzyloxy)-4-(octadecyloxy)benzoic acid (35). To a stirred suspension of benzoate $34(2.89 \mathrm{~g}, 5.7 \mathrm{mmol})$ in distilled $\mathrm{MeOH}(100 \mathrm{~mL})$ was added 5 $\mathrm{M} \mathrm{NaOH}(18 \mathrm{~mL}, 90 \mathrm{mmol})$ and the solution refluxed for 20 hours. The reaction was cooled, the $\mathrm{MeOH}$ removed in vacuo and the mixture diluted with water $(500 \mathrm{~mL})$, acidified to $\mathrm{pH}=1$ with concentrated $\mathrm{HCl}$, and extracted with hot EtOAc $(2 \times 500 \mathrm{~mL})$. The combined organic layers were dried $\left(\mathrm{MgSO}_{4}\right)$, filtered and concentrated to give the title compound as an offwhite solid (2.75 g, $5.5 \mathrm{mmol}, 98 \%)$. $\mathrm{R}_{f}=0.21$ (petroleum ether:EtOAc, 4:1, 
v/v); IR (film) 2916, 2847, 1696, 1671, 1607, 1572, 1505, 1465, 1428, 1412, 1376, 1333, 1272, 1255, 1211, 1186, 1160, 1101, 1044, 930, $825 \mathrm{~cm}^{-1} ;{ }^{1} \mathrm{H}-\mathrm{NMR}\left(500 \mathrm{MHz}, \mathrm{C}_{5} \mathrm{D}_{5} \mathrm{~N}\right) \delta 8.41\left(\mathrm{~d}, J_{5,6}=8.7 \mathrm{~Hz}\right.$, $1 \mathrm{H}, \mathrm{H}-6), 7.82$ (d, $\left.J_{2^{\prime}, 3^{\prime}}=7.7 \mathrm{~Hz}, 2 \mathrm{H}, \mathrm{H}-2^{\prime}\right), 7.39$ (t, $\left.J_{2^{\prime}, 3^{\prime}}=J_{3^{\prime}, 4^{\prime}}=7.7 \mathrm{~Hz}, 2 \mathrm{H} \mathrm{H}-3^{\prime}\right), 7.29$ (t, $J_{3^{\prime}, 4^{\prime}}=$ $\left.7.4 \mathrm{~Hz}, 1 \mathrm{H}, \mathrm{H}^{-} 4^{\prime}\right), 6.96$ (d, $\left.J_{3,5}=2.2 \mathrm{~Hz}, 1 \mathrm{H}, \mathrm{H}-3\right), 6.78$ (dd, $\left.J_{5,6}=8.5 \mathrm{~Hz}, J_{3,5}=1.9 \mathrm{~Hz}, 1 \mathrm{H}, \mathrm{H}-5\right), 5.37$ (s, 2H, $\left.\mathrm{CH}_{2}-O-\mathrm{Bn}\right), 4.00$ (t, $\left.J_{8,9}=6.5 \mathrm{~Hz}, 2 \mathrm{H}, \mathrm{H}-8\right), 1.77$ (p, $\left.J_{8,9}=J_{9,10}=7.1 \mathrm{~Hz}, 2 \mathrm{H}, \mathrm{H}-9\right), 1.51-1.03$ $(\mathrm{m}, 30 \mathrm{H}, \mathrm{H}-10-\mathrm{H}-24), 0.88$ (t, $\left.J_{24,25}=6.8 \mathrm{~Hz}, 3 \mathrm{H}, \mathrm{H}-25\right) ;{ }^{13} \mathrm{C}-\mathrm{NMR}\left(125 \mathrm{MHz}, \mathrm{C}_{5} \mathrm{D}_{5} \mathrm{~N}\right) \delta 168.7$ (C=O), 164.4 (C-4), 161.3 (C-2), 138.3 (C-1'), 135.1 (C-6), 129.3 (C-2'), 128.5 (C-4'), 128.0 (C-3’), 115.5 (C-1), 106.9 (C-5), 102.2 (C-3), $71.2\left(\mathrm{CH}_{2}-\mathrm{O}-\mathrm{Bn}\right), 68.9$ (C-8), 32.6, 30.50. 30.49, 30.47, 30.46, 30.42, 30.39, 30.37, 30.13, 30.11, 29.9, 23.4 (C-10 - C-24), 26.8 (C-9), 14.8 (C-25); HRMS (ESI) m/z $[\mathrm{M}-\mathrm{H}]^{-}$calcd. for $\left[\mathrm{C}_{32} \mathrm{H}_{47} \mathrm{O}_{4}\right]^{-}: 495.3480$, obsd. 495.3477.

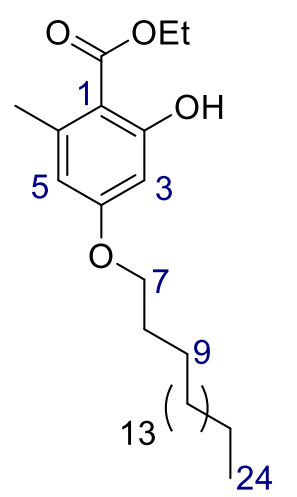

Ethyl 2-hydroxy-4-(octadecyloxy)-6-methyl benzoate (38). To a solution of ethyl 2,4-dihydroxy-6-methyl benzoate $(96 \mathrm{mg}, 0.49 \mathrm{mmol})$ in acetone $(10 \mathrm{~mL})$ were added $\mathrm{K}_{2} \mathrm{CO}_{3}$ (136 mg, $0.98 \mathrm{mmol}$, 1-bromooctadecane (246 g, $0.74 \mathrm{mmol}$ ) and TBAI (19 $\mathrm{mg}, 0.05 \mathrm{mmol})$. The reaction mixture was refluxed for $20 \mathrm{~h}$ and then concentrated. The resultant residue was purified by gradient silica gel flash column chromatography (petroleum ether to petroleum ether:EtOAc, 9:1, v/v) to give the title compound as a white solid (200 mg, $0.45 \mathrm{mmol}, 91 \%) . \mathrm{R}_{f}=0.60$ (petroleum ether:EtOAc, 9:1, v/v); IR (film) 2945, 2915, 2847, 1646, 1611, 1581, 1468, 1402, 1380, 1364, 1321, 1298, 1260, 1215, 1176, 1129, 1107, 1040, 994, 953, 847, $814 \mathrm{~cm}^{-1} ;{ }^{1} \mathrm{H}-\mathrm{NMR}\left(500 \mathrm{MHz}, \mathrm{CDCl}_{3}\right) \delta$ 11.85 (s, 1H, 2-OH), 6.31 (s, 1H, H-3), 6.28 (s, 1H, H-5), 4.39 (q, J = 7.1 Hz, 2H, CH $2-\mathrm{OEt}$ ), 3.94 (t, $\left.J_{7,8}=6.3 \mathrm{~Hz}, 2 \mathrm{H}, \mathrm{H}-7\right), 2.50(\mathrm{~s}, 3 \mathrm{H}, 6-\mathrm{Me}), 1.76$ (p, $\left.J_{7,8}=J_{8,9}=7.0 \mathrm{~Hz}, 2 \mathrm{H}, \mathrm{H}-8\right), 1.43\left(\mathrm{~m}, 5 \mathrm{H}, \mathrm{CH}_{3^{-}}\right.$ OEt \& H-9), 1.34-1.18 (m, 56 H, H-10-H-23), 0.88 (t, $\left.J_{23,24}=6.8 \mathrm{~Hz}, 3 \mathrm{H}, \mathrm{H}-24\right) ;{ }^{13} \mathrm{C}-\mathrm{NMR}\left(\mathrm{CDCl}_{3}\right.$, $150 \mathrm{MHz}) \delta 172.0(\mathrm{C}=\mathrm{O}), 165.7$ (C-2), 163.6 (C-4), 143.2 (C-6), 111.7 (C-5), 105.2 (C-1), 99.3 (C3), 68.2 ( $\mathrm{CH}_{2}$-OEt), 61.3 (C-7), 32.1, 29.9 29.84, 29.82, 29.81, 29.80, 29.73, 29.70, 29.5, 29.2, 26.1, 24.6, 22.9 (C-8-C-23), 14.4 (6-Me), 14.3 (C-24); HRMS (ESI) $m / z$ [M+H $]^{+}$calcd. for $\left[\mathrm{C}_{28} \mathrm{H}_{48} \mathrm{O}_{4}+\mathrm{H}\right]^{+}$: 449.3625, obsd.: 449.3625 . 


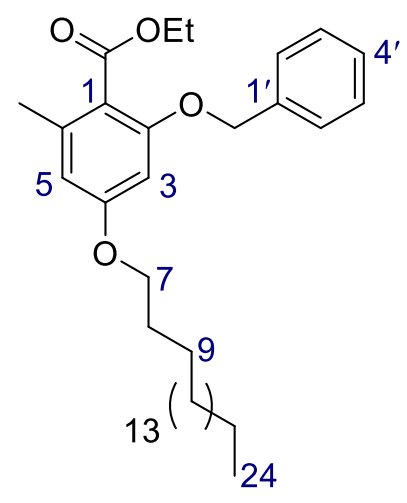

Ethyl 2-(benzyloxy)-4-(octadecyloxy)-6-methyl benzoate (39). To a solution of benzoate 38 (188 mg, $0.42 \mathrm{mmol})$ in acetone $(20 \mathrm{~mL})$ were added $\mathrm{K}_{2} \mathrm{CO}_{3}(168 \mathrm{mg}, 1.2 \mathrm{mmol}), \mathrm{BnBr}(1.4 \mathrm{~mL}, 1.3 \mathrm{mmol})$ and TBAI (15 mg, $0.04 \mathrm{mmol})$. The reaction mixture was refluxed for $20 \mathrm{~h}$ and then concentrated. The resultant residue was purified by gradient silica gel flash column chromatography (petroleum ether to petroleum ether:EtOAc, 9:1, $v / v)$ to give the title compound as white solid (208 $\mathrm{mg}, 0.39 \mathrm{mmol}, 92 \%) . \mathrm{R}_{f}$ $=0.36$ (petroleum ether:EtOAc, 9:1, v/v); IR (film) 2916, 2849, 1704, 1604, $1578,1499,1470,1442,1387,1364,1321,1271,1238,1210,1165,1085,1052,1043,999,943,838$, $807 \mathrm{~cm}^{-1} ;{ }^{1} \mathrm{H}-\mathrm{NMR}\left(500 \mathrm{MHz}, \mathrm{CDCl}_{3}\right) \delta 7.40\left(\mathrm{~d}, J_{2^{\prime}, 3^{\prime}}=7.1 \mathrm{~Hz}, 2 \mathrm{H}, \mathrm{H}-2^{\prime}\right), 7.35\left(\mathrm{t}, J_{2^{\prime}, 3^{\prime}}=J_{3^{\prime}, 4^{\prime}}=7.1 \mathrm{~Hz}\right.$, 2H, H-3'), 7.30 (d, J $\left.J_{3^{\prime}, 4^{\prime}}=7.1 \mathrm{~Hz}, 1 \mathrm{H}, \mathrm{H}-4^{\prime}\right), 6.35$ (s, 1H, H-3), 6.32 (s, 1H, H-5) 6.32 (s, 2H, $\mathrm{CH}_{2}-\mathrm{O}-$ Bn), 4.33 (q, $\left.J=7.1 \mathrm{~Hz}, 2 \mathrm{H}, \mathrm{CH}_{2}-\mathrm{OEt}\right), 3.91$ (t, $\left.J_{7,8}=6.6 \mathrm{~Hz}, 2 \mathrm{H}, \mathrm{H}-7\right), 2.30$ (s, 3H, 6-Me), 1.74 (p, $\left.J_{7,8}=J_{8,9}=7.1 \mathrm{~Hz}, 2 \mathrm{H}, \mathrm{H}-8\right), 1.42(\mathrm{~m}, 2 \mathrm{H}, \mathrm{H}-9), 1.35-1.20\left(\mathrm{~m}, 31 \mathrm{H}, \mathrm{H}-10-\mathrm{H}-23 \& \mathrm{CH}_{3}-\mathrm{OEt}\right), 0.88(\mathrm{t}$, $\left.J_{23,24}=7.0 \mathrm{~Hz}, 3 \mathrm{H}, \mathrm{H}-24\right) ;{ }^{13} \mathrm{C}-\mathrm{NMR}\left(150 \mathrm{MHz}, \mathrm{CDCl}_{3}\right) \delta 168.4(\mathrm{C}=\mathrm{O}), 160.9(\mathrm{C}-4), 157.3(\mathrm{C}-2)$, 138.3 (C-6), 136.9 (C-1'), 128.6, 127.9, 127.2 (C-2'-C-4'), 117.1 (C-1), 107.9 (C-5), 98.1 (C-3), 70.5 $\left(\mathrm{CH}_{2}-\mathrm{O}-\mathrm{Bn}\right), 68.2$ ( $\left.\mathrm{CH}_{2}-\mathrm{OEt}\right), 61.0$ (C-7), 32.1, 29.9 , 29.83, 29.81, 29.80, 29.75, 29.71, 29.52, 29.51, 29.3, 26.1, 22.8, 20.0 (C-8-C-23), 14.4 ( $\left.\mathrm{CH}_{3}-\mathrm{OEt}\right), 14.3$ (C-24); HRMS (ESI) $m / z[\mathrm{M}+\mathrm{H}]^{+}$calcd. for: $\left[\mathrm{C}_{35} \mathrm{H}_{54} \mathrm{O}_{4}+\mathrm{H}\right]^{+}:$539.4095, obsd.: 539.4098.

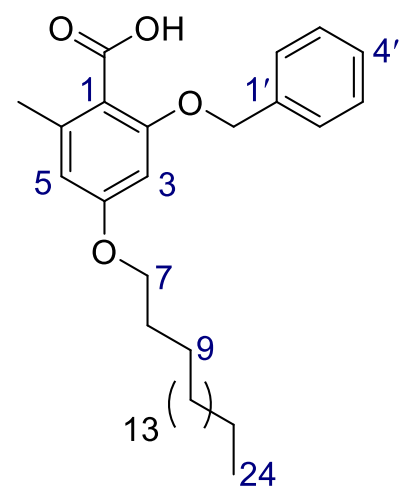

2-(Benzyloxy)-4-(octadecyloxy)-6-methyl benzoate (40). To a solution of benzoate 39 (123 mg, $0.23 \mathrm{mmol})$ in ethanol $(20 \mathrm{~mL})$ was added $\mathrm{NaOH}(5.0$ $\mathrm{mL}, 25 \mathrm{mmol}, 5.0 \mathrm{M})$. The reaction mixture was refluxed for 20 hours. The reaction was cooled, diluted with water, acidified to $\mathrm{pH}=1$ with conc. $\mathrm{HCl}$ and extracted with EtOAc. The organic layer was dried $\left(\mathrm{MgSO}_{4}\right)$ filtered and concentrated to give the title compound as a white solid (106 mg, $0.21 \mathrm{mmol}$, $91 \%$ ). $\mathrm{R}_{f}=0.26$ (petroleum ether:EtOAc, 4:1, v/v); IR (film) 2919, 2848, $1681,1604,1579,1498,1467,1382,1293,1328,1293,1233,1206,1173,1097,1050,1029,950,843$, 828, $808 \mathrm{~cm}^{-1} ;{ }^{1} \mathrm{H}-\mathrm{NMR}\left(500 \mathrm{MHz}, \mathrm{CDCl}_{3}\right) \delta$ 7.45-7.34 (m, 5H, H-2'-H-4'), 6.47 (s, H-3 \& H-5), 5.19 $\left(\mathrm{s}, 2 \mathrm{H}, \mathrm{CH}_{2}-O-\mathrm{Bn}\right), 3.97\left(\mathrm{t}, J_{7,8}=6.6 \mathrm{~Hz}, 2 \mathrm{H}, \mathrm{H}-7\right), 2.60(\mathrm{~s}, 3 \mathrm{H}, 6-\mathrm{Me}), 1.77\left(\mathrm{p}, J_{7,8}=J_{8,9}=7.0 \mathrm{~Hz}\right.$, $2 \mathrm{H}, \mathrm{H}-8), 1.45$ (m, 2H, H-9), 1.42-1.23 (m, 28H, H-10-H-23), 0.88 (t, J23,4 = 6.8 Hz, 3H, H-24); ${ }^{13} \mathrm{C}-$ NMR (150 MHz, $\left.\mathrm{CDCl}_{3}\right) \delta 166.2(\mathrm{C}=\mathrm{O}), 162.0$ (C-4), 159.0 (C-2), 145.6 (C-6), 134.8 (C-1'), 129.0, 127.8 (C-2'-C-4'), 111.4 (C-1), 110.8 (C-5), 98.4 (C-3), 72.1 ( $\left.\mathrm{CH}_{2}-O-\mathrm{Bn}\right), 68.3$ (C-7), 31.9, 29.70. 29.66, 29.60, 29.55, 29.4, 29.3, 26.0, 23.3, 22.7 (C-8-C-23), 14.1 (C-24); HRMS (ESI) m/z [M-H] calcd. for $\left[\mathrm{C}_{33} \mathrm{H}_{49} \mathrm{O}_{4}\right]^{-:}: 509.3636$, obsd. 509.3633. 


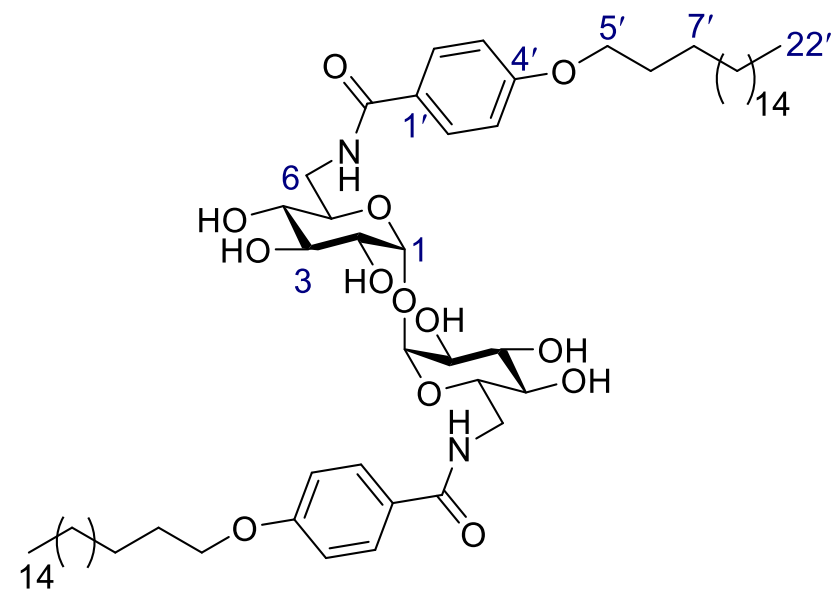

6,6'-Dideoxy-di-(4-octadecyloxybenzoylamido)- $\alpha, \boldsymbol{\alpha}^{\prime}$-trehalose (2a). Di-azide 23 (54 mg, $0.14 \mathrm{mmol}), \mathrm{PMe}_{3}(1.4 \mathrm{~mL} .1 .4 \mathrm{mmol})$, water $\quad(0.15 \quad \mathrm{~mL}, \quad 8.3 \quad \mathrm{mmol}), \quad 4-$ octadecyloxybenzoic acid (137 $\mathrm{mg}, 0.35 \mathrm{mmol})$, DIPEA (0.12 mL, $0.74 \mathrm{mmol})$, and HBTU (132 $\mathrm{mg}, 0.35 \mathrm{mmol})$ were subjected to the general procedure for the Staudinger reduction and coupling reaction. The resultant residue was dissolved in hot ${ }^{t} \mathrm{BuOH}: \mathrm{EtOAc}(40 \mathrm{~mL}, 2: 1, v / v)$ and washed with $\mathrm{HCl}(75 \mathrm{~mL}, 0.1 \mathrm{M})$, sat. $\mathrm{NaHCO}_{3}$ $(75 \mathrm{~mL})$ and brine $(75 \mathrm{~mL})$. The organic layer was diluted with pyridine $(10 \mathrm{~mL})$, dried $\left(\mathrm{MgSO}_{4}\right)$, filtered and concentrated. The resultant residue was purified by gradient silica gel flash chromatography $\left(\mathrm{CH}_{2} \mathrm{Cl}_{2}\right.$ to $\left.\mathrm{CH}_{2} \mathrm{Cl}_{2}: \mathrm{MeOH}, 85: 15, v / v\right)$ to give the title compound as a white solid (85 mg, $0.08 \mathrm{mmol}, 57 \%) . \mathrm{R}_{f}=0.61\left(\mathrm{CH}_{2} \mathrm{Cl}_{2}: \mathrm{MeOH}, 4: 1, v / v\right) ;[\alpha]_{\mathrm{D}}^{20}=+28(c=1.0$, pyridine); IR (film) 3327, 2915, 2849, 1623, 1607, 1551, 1505, 1467, 1302, 1254, 1182, 1147, 1103, 1035, 993, $840 \mathrm{~cm}^{-1}$; ${ }^{1} \mathrm{H}-\mathrm{NMR}\left(500 \mathrm{MHz}, \mathrm{C}_{5} \mathrm{D}_{5} \mathrm{~N}\right) \delta 9.02$ (bs, 2H, NH), 8.33 (d, $\left.J_{2^{\prime}, 3^{\prime}}=8.6 \mathrm{~Hz}, 4 \mathrm{H}, \mathrm{H}-2^{\prime}\right), 7.06$ (d, $J_{2^{\prime}, 3^{\prime}}=$ $\left.8.9 \mathrm{~Hz}, 4 \mathrm{H}, \mathrm{H}-3^{\prime}\right), 5.76$ (d, $\left.J_{1,2}=3.5 \mathrm{~Hz}, 2 \mathrm{H}, \mathrm{H}-1\right), 5.06$ (m, $\left.1 \mathrm{H}, \mathrm{H}-5\right), 4.70$ (t, $J_{3,4}=J_{4,5}=9.3 \mathrm{~Hz}, 2 \mathrm{H}$, H-3), $4.43\left(\mathrm{dd}, J_{6 \mathrm{a}, 6 \mathrm{~b}}=13.0 \mathrm{~Hz}, J_{5,6 \mathrm{a}}=6.2 \mathrm{~Hz}, 2 \mathrm{H}, \mathrm{H}-6 \mathrm{a}\right), 4.24\left(\mathrm{dd}, J_{2,3}=9.5 \mathrm{~Hz}, J_{1,2}=6.2 \mathrm{~Hz}, 2 \mathrm{H}, \mathrm{H}-\right.$ 2), $4.14\left(\mathrm{bd}, J_{6 \mathrm{a}, 6 \mathrm{~b}}=13.9 \mathrm{~Hz}, 2 \mathrm{H}, \mathrm{H}-6 \mathrm{~b}\right), 4.00\left(\mathrm{t}, J_{3,4}=J_{4,5}=9.6 \mathrm{~Hz}, 2 \mathrm{H}, \mathrm{H}-4\right), 3.92\left(\mathrm{t}, J_{5^{\prime}, 6^{\prime}}=6.6 \mathrm{~Hz}\right.$, $\left.4 \mathrm{H}, \mathrm{H}-5^{\prime}\right), 1.74$ (p, $\left.J_{5^{\prime}, 6^{\prime}}=J_{6^{\prime}, 7^{\prime}}=7.1 \mathrm{~Hz}, 4 \mathrm{H}, \mathrm{H}-6^{\prime}\right), 1.46-1.39$ (m, 4H, H-7'), 1.35-1.22 (m, 28H, H$\left.8^{\prime}-\mathrm{H}-21^{\prime}\right), 0.88\left(\mathrm{t}, J_{21^{\prime}, 22^{\prime}}=6.9 \mathrm{~Hz}, 6 \mathrm{H}, \mathrm{H}-22^{\prime}\right) ;{ }^{13} \mathrm{C}-\mathrm{NMR}\left(150 \mathrm{MHz}, \mathrm{C}_{5} \mathrm{D}_{5} \mathrm{~N}\right) \delta 169.0(\mathrm{C}=\mathrm{O}), 162.6$ (C-4'), 130.4 (C-2'), 128.2 (C-1'), 115.0 (C-3'), 97.1 (C-1), 74.8 (C-3), 74.0 (C-2), 73.9 (C-4), 72.9 (C-5), 68.8 (C-5') 44.7 (C-6), 42.5, 32.6, 30.48, 30.47, 30.41, 30.40, 30.37, 30.2 , 30.1 , 30.0, 23.43 (C6' \& C-8'-C-21'), 26.8 (C-7'), 14.8 (C-22'); HRMS (ESI) $m / z[\mathrm{M}+\mathrm{H}]^{+}$calcd. for $\left[\mathrm{C}_{62} \mathrm{H}_{104} \mathrm{~N}_{2} \mathrm{O}_{13}+\mathrm{H}\right]^{+}$: 1085.7611, obsd. 1085.7609 . 


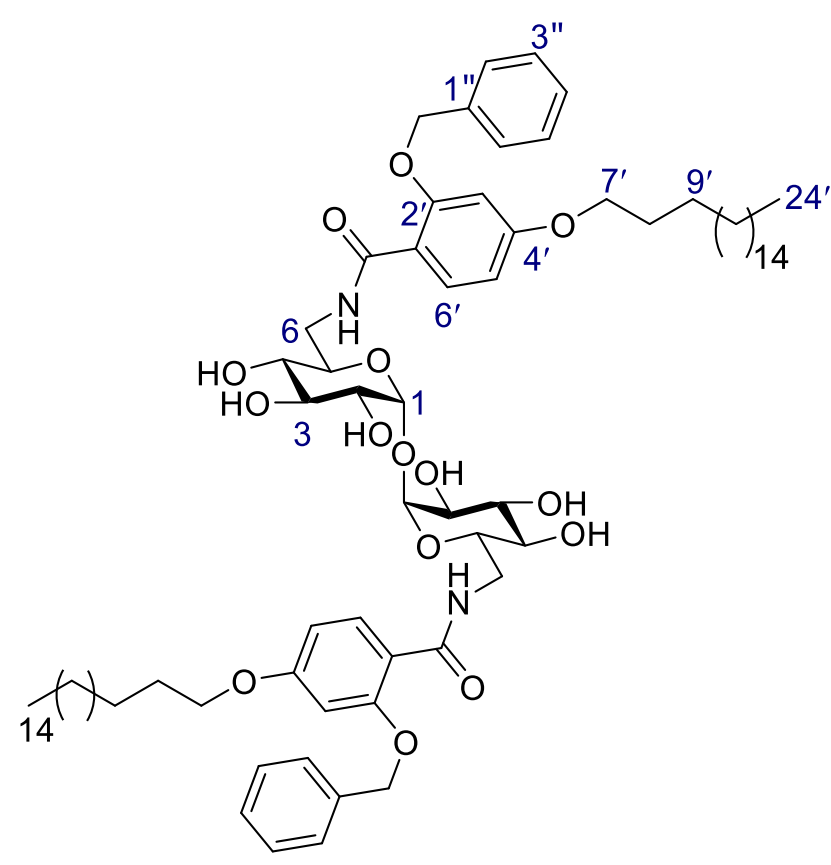

6,6'-Dideoxy-di-(2-O-benzyl-4-octadecyloxybenzoylamido)- $\alpha, \alpha^{\prime}$-trehalose (36). Di-azide 23 (55 mg, $0.14 \mathrm{mmol}), \mathrm{PMe}_{3}(1.4 \mathrm{~mL}, 1.4 \mathrm{mmol})$, water $(0.15 \mathrm{~mL}, 8.3 \mathrm{mmol})$, 2-(benzyloxy)-4(octadecyloxy)benzoic acid 35 (173 mg, 0.35 mmol), HBTU (132 mg, $0.35 \mathrm{mmol}$ ) and DIPEA (0.15 $\mathrm{mL}, 0.86 \mathrm{mmol})$ were subjected to the general procedure for the Staudinger reduction and coupling reaction. The resultant residue was dissolved in hot ${ }^{t} \mathrm{BuOH}:$ EtOAc $(40 \mathrm{~mL}, 2: 1, v / v)$ and washed with $\mathrm{HCl}(60 \mathrm{~mL}, 0.1 \mathrm{M})$, sat. $\mathrm{NaHCO}_{3}(60 \mathrm{~mL})$, and brine $(60 \mathrm{~mL})$. The organic layer was diluted with pyridine $(20 \mathrm{~mL})$, dried $\left(\mathrm{MgSO}_{4}\right)$, filtered and concentrated. The resultant residue was purified by gradient silica gel flash column chromatography $\left(\mathrm{CH}_{2} \mathrm{Cl}_{2}\right.$ to $\left.\mathrm{CH}_{2} \mathrm{Cl}_{2}: \mathrm{MeOH}, 9: 1, v / v\right)$ to give the title compound as a white solid (168 mg, $0.13 \mathrm{mmol}, 93 \%) . \mathrm{R}_{f}=0.35\left(\mathrm{CH}_{2} \mathrm{Cl}_{2}: \mathrm{MeOH}, 9: 1, v / v\right) ;[\alpha]_{\mathrm{D}}^{19}=+39(c=1.0$, pyridine) ; IR (film) 3387, 2916, 2849, 1628, 1605, 1544, 1498, 1466, 1391, 1257, 1175, 1146, 1110, 1035, 996, $840 \mathrm{~cm}^{-1} ;{ }^{1} \mathrm{H}-\mathrm{NMR}\left(500 \mathrm{MHz}, \mathrm{C}_{5} \mathrm{D}_{5} \mathrm{~N}\right) \delta 8.86\left(\mathrm{bt}, J_{\mathrm{NH}, 6 \mathrm{a}}=J_{\mathrm{NH}, 6 \mathrm{~b}}=5.4 \mathrm{~Hz}, 2 \mathrm{H}, \mathrm{NH}\right), 8.59\left(\mathrm{~d}, J_{5^{\prime}, 6^{\prime}}=\right.$ $\left.8.5 \mathrm{~Hz}, 2 \mathrm{H}, \mathrm{H}-6^{\prime}\right), 7.60$ (d, $\left.J_{2^{\prime \prime}, 3^{\prime \prime}}=8.1 \mathrm{~Hz}, 4 \mathrm{H}, \mathrm{H}-2^{\prime \prime}\right), 7.41$ (t, $\left.J_{2^{\prime \prime}} 3^{\prime \prime}=J_{3^{\prime \prime}} 4^{\prime \prime}=7.6 \mathrm{~Hz}, 4 \mathrm{H}, \mathrm{H}-3 "\right), 7.29$ (t, $\left.J_{3^{\prime \prime}, 4^{\prime \prime}}=7.4 \mathrm{~Hz}, 2 \mathrm{H}, \mathrm{H}-4 "\right), 6.86$ (s, 2H, H-3'), 6.77 (d, $\left.J_{5^{\prime}, 6^{\prime}}=8.7 \mathrm{~Hz}, 2 \mathrm{H}, \mathrm{H}-5^{\prime}\right), 5.64$ (d, J1,2 = 3.4 Hz, 2H, H-1), 5.31 (s, $\left.\mathrm{CH}_{2}-O-\mathrm{Bn}\right), 5.07$ (m, 2H, H-5), 4.70 (t, $\left.J_{2,3}=J_{3,4}=9.2 \mathrm{~Hz}, 2 \mathrm{H}, \mathrm{H}-3\right), 4.62$ (m, 2H, H-6a), 4.11 (dd, $\left.J_{2,3}=9.5 \mathrm{~Hz}, J_{1,2}=3.7 \mathrm{~Hz}, 2 \mathrm{H}, \mathrm{H}-2\right), 4.06$ (m, 2H, H-6b), 4.01 (t, $J_{3,4}=J_{4,5}=9.4 \mathrm{~Hz}$, $2 \mathrm{H}, \mathrm{H}-4), 3.95$ (t, $\left.J_{7^{\prime}, 8^{\prime}}=6.4 \mathrm{~Hz}, 4 \mathrm{H}, \mathrm{H}-7^{\prime}\right), 1.73$ (p, $\left.J_{7^{\prime}, 8^{\prime}}=J_{8^{\prime}}, 9^{\prime}=6.9 \mathrm{~Hz}, 4 \mathrm{H}, \mathrm{H}-8^{\prime}\right), 1.49-1.37$ (m, 56H, H-10'-H-23'), 0.88 (t, J J23',24' = 6.8 Hz, 6H, H-24'); ${ }^{13} \mathrm{C}-\mathrm{NMR}\left(125 \mathrm{MHz}, \mathrm{C}_{5} \mathrm{D}_{5} \mathrm{~N}_{5}\right) \delta 166.7(\mathrm{C}=\mathrm{O}), 163.8$ (C-4'), 159.1 (C-2'), 137.1 (C-1"), 134.7 (C-6'), 129.7 (C-3"), 129.1 (C-4"), 128.5 (C-2"), 116.1 (C-4'), 107.4 (C-5'), 101.5 (C-3'), 96.5 (C-1), 74.7 (C-3), 73.9 (C-2), 73.5 (C-4), 72.5 (C-5), $71.6\left(\mathrm{CH}_{2}-\mathrm{O}-\right.$ Bn), 69.0 (C-7'), 41.9 (C-6), 32.6, 30.51, 30.49, 30.48, 30.42, 40.41, 30.38, 30.16, 30.12, 29.9, 26.8, $23.4\left(\mathrm{C}-8^{\prime}-\mathrm{C}-23\right.$ '), 14.8 (C-24'); HRMS (ESI) $m / z[\mathrm{M}+\mathrm{H}]^{+}$calcd. for $\left[\mathrm{C}_{76} \mathrm{H}_{116} \mathrm{~N}_{2} \mathrm{O}_{15}+\mathrm{H}\right]^{+}: 1297.8448$, obsd. 1297.8442 . 


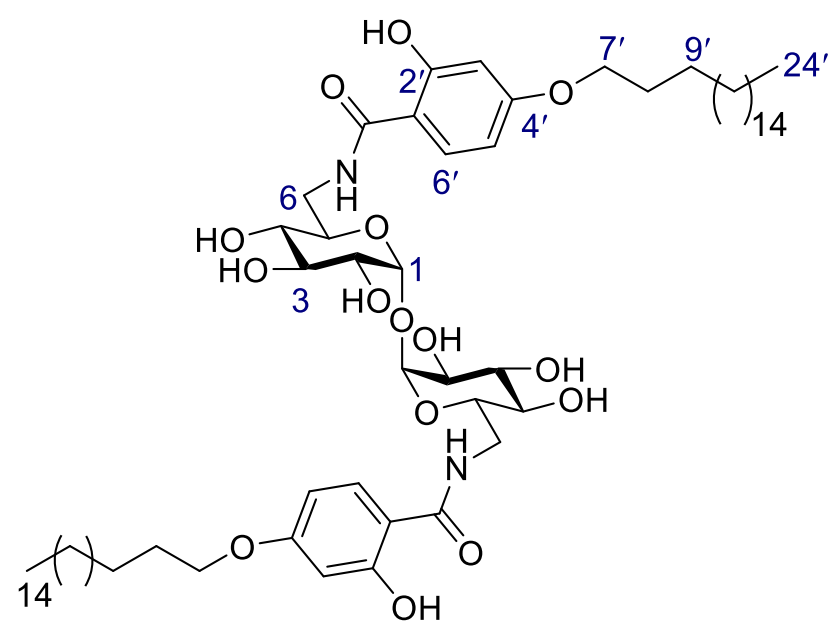

6,6'-Dideoxy-(2-hydroxy-4-octadecyloxy-
benzoylamido)- $\boldsymbol{\alpha}, \boldsymbol{\alpha}^{\prime}$-trehalose $\quad(\mathbf{2 b})$. To a
solution of di-amide $36(126 \mathrm{mg}, 0.10 \mathrm{mmol})$ in
distilled $\mathrm{CH}_{2} \mathrm{Cl}_{2}: \mathrm{MeOH}(6 \mathrm{~mL}, 1: 1, v / v)$ was
added $\mathrm{Pd}(\mathrm{OH})_{2} / \mathrm{C}(10 \mathrm{mg}) . \mathrm{H}_{2}$ was bubbled
through the suspension for $48 \mathrm{~h}$, and then the
reaction mixture was diluted with pyridine (15
mL) and filtered over celite. The filtrate was
concentrated and the resultant residue purified by gradient silica gel flash column chromatography $\left(\mathrm{CH}_{2} \mathrm{Cl}_{2}\right.$ to $\left.\mathrm{CH}_{2} \mathrm{Cl}_{2}: \mathrm{MeOH}, 9: 1, v / v\right)$ to give the title compound as a white solid (82 mg, $0.07 \mathrm{mmol}, 75 \%) . \mathrm{R}_{f}=0.37\left(\mathrm{CH}_{2} \mathrm{Cl}_{2}: \mathrm{MeOH}, 85: 15, v / v\right) ;[\alpha]_{\mathrm{D}}^{20}=$ +24 ( $c=1.0$, pyridine); IR (film) 3348, 2917, 2849, 1642, 1616, 1597, 1551, 1534, 1503, 1469, 1438, 1377, 1335, 1275, 1259, 1191, 1179, 1042, 996, 940, 855, 834, 815, $805 \mathrm{~cm}^{-1} ;{ }^{1} \mathrm{H}-\mathrm{NMR}(500 \mathrm{MHz}$, $\left.\mathrm{C}_{5} \mathrm{D}_{5} \mathrm{~N}\right) \delta 9.18\left(\mathrm{bt}, J_{\mathrm{NH}, 6 \mathrm{a}}=J_{\mathrm{NH}, 6 \mathrm{~b}}=5.4 \mathrm{~Hz}, 2 \mathrm{H}, \mathrm{NH}\right), 8.28\left(\mathrm{~d}, J_{5^{\prime}, 6^{\prime}}=8.8 \mathrm{~Hz}, 2 \mathrm{H}, \mathrm{H}-6^{\prime}\right), 6.82\left(\mathrm{~d}, J_{3^{\prime}, 5^{\prime}}=\right.$ $\left.2.1 \mathrm{~Hz}, 2 \mathrm{H}, \mathrm{H}-3^{\prime}\right), 6.59$ (dd, $\left.J_{5^{\prime}, 6^{\prime}}=8.8 \mathrm{~Hz}, J_{3^{\prime}, 5^{\prime}}=2.4 \mathrm{~Hz}, 2 \mathrm{H}, \mathrm{H}-5^{\prime}\right), 5.76\left(\mathrm{~d}, J_{1,2}=3.6 \mathrm{~Hz}, 2 \mathrm{H}, \mathrm{H}-1\right)$, $5.06(\mathrm{~m}, 2 \mathrm{H}, \mathrm{H}-5), 4.67$ (t, $\left.J_{2,3}=J_{3,4}=9.3 \mathrm{~Hz}, 2 \mathrm{H}, \mathrm{H}-3\right), 4.28\left(\mathrm{~m}, 4 \mathrm{H}, \mathrm{H}-7^{\prime}\right), 4.19$ (dd, $J_{2,3}=9,9 \mathrm{~Hz}$, $\left.J_{1,2}=3.9 \mathrm{~Hz}, 2 \mathrm{H}, \mathrm{H}-2\right), 3.97$ (t, $\left.J_{3,4}=J_{4,5}=9.3 \mathrm{~Hz}, 2 \mathrm{H}, \mathrm{H}-4\right), 3.93$ (m, 4H, H-6a \& H-6b), 1.72 (p, $J_{7^{\prime}, 8}$ $\left.=J_{8^{\prime}, 9^{\prime}}=7.0 \mathrm{~Hz}, 4 \mathrm{H}, \mathrm{H}-8^{\prime}\right), 1.41\left(\mathrm{~m}, 4 \mathrm{H}, \mathrm{H}-9^{\prime}\right), 1.35-1.21\left(\mathrm{~m}, 56 \mathrm{H}, \mathrm{H}-10^{\prime}-\mathrm{H}^{\prime}-23^{\prime}\right), 0.88$ (t, $J_{23^{\prime}, 24^{\prime}}=7.0$ $\left.\mathrm{Hz}, 6 \mathrm{H}, \mathrm{H}-24^{\prime}\right) ;{ }^{13} \mathrm{C}-\mathrm{NMR}\left(125 \mathrm{MHz}, \mathrm{C}_{5} \mathrm{D}_{5} \mathrm{~N}\right) \delta 170.3$ (C=O), 163.8 (C-1'), 163.2 (C-2'), 129.7 (C-6'), 109.5 (C-4'), 106.7 (C-5'), 102.5 (C-3'), 96.3 (C-1), 74.5 (C-3), 73.4 (C-4), 73.2 (C-2), 71.9 (C-5), 68.1 (C-6), 41.5 (C-7'), 31.9, 29.80, 29.79, 29.76, 29.72, 29.69, 29.65, 29.43, 29.41, 29.2 , 26.1, 22.7 (C-8'C-23'), 14.1 (C-24'), HRMS (ESI) $m / z,[\mathrm{M}+\mathrm{H}]^{+}$calcd. for $\left[\mathrm{C}_{62} \mathrm{H}_{104} \mathrm{~N}_{2} \mathrm{O}_{15}+\mathrm{H}\right]^{+}: 1117.7509$, obsd. 1117.7513. 


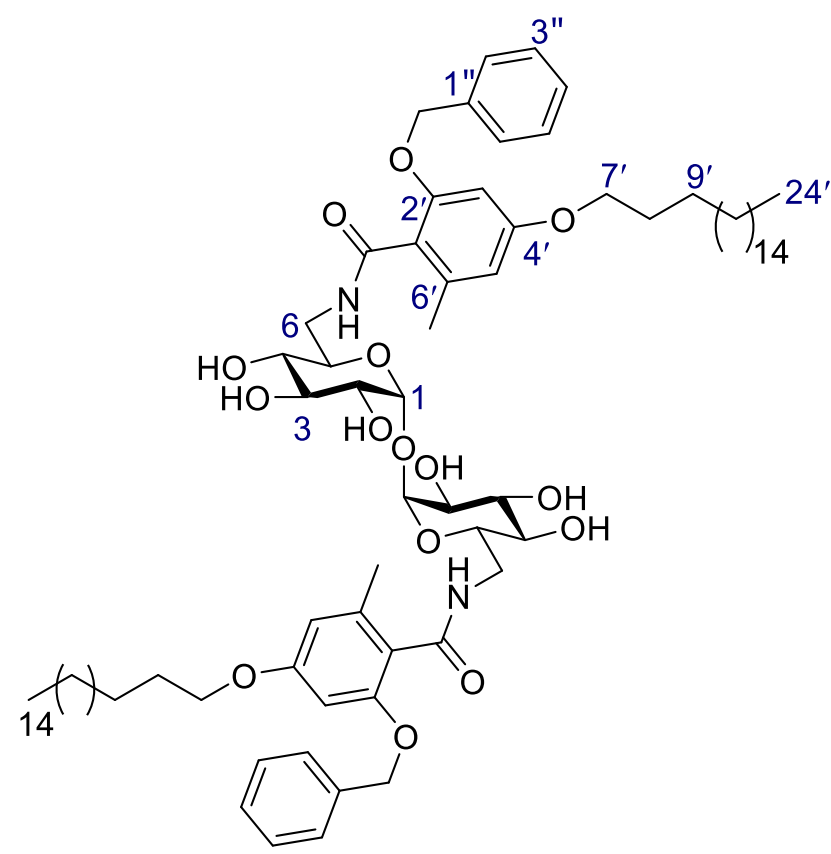

6,6'-Dideoxy-(2-O-benzyl-6-methyl-4octadecyloxy-benzoylamido)- $\alpha, \alpha^{\prime}$-trehalose (41). Di-azide 23 (28 mg, $0.07 \mathrm{mmol}$ ), $\mathrm{PMe}_{3}(0.7$ $\mathrm{mL}, 0.7 \mathrm{mmol})$, water $(0.08 \mathrm{~mL}, 4.4 \mathrm{mmol}), 2-O$ benzyl-3-methyl-octadecyloxy benzoic acid (85 $\mathrm{mg}, 0.17)$, DIPEA (0.06 mL, $0.34 \mathrm{mmol})$, and HBTU (70 $\mathrm{mg}, 0.18 \mathrm{mmol}$ ) were subjected to the general procedure for the Staudinger reduction and the coupling reaction. The resultant residue was dissolved in hot ${ }^{t} \mathrm{BuOH}: \mathrm{EtOAc}(50 \mathrm{~mL}, 2: 1$, $v / v)$ and washed with $0.1 \mathrm{M} \mathrm{HCl}(50 \mathrm{~mL})$, sat. $\mathrm{NaHCO}_{3}(50 \mathrm{~mL})$, and brine $(50 \mathrm{~mL})$. The organic layer was dried $\left(\mathrm{MgSO}_{4}\right)$, filtered and concentrated. The resultant residue was purified by gradient silica gel flash column chromatography $\left(\mathrm{CH}_{2} \mathrm{Cl}_{2}\right.$ to $\left.\mathrm{CH}_{2} \mathrm{Cl}_{2}: \mathrm{MeOH}, 9: 1, v / v\right)$ to give the title compound as a pink solid (47 mg, $0.04 \mathrm{mmol}, 50$ $\%) . \mathrm{R}_{f}=0.26\left(\mathrm{CH}_{2} \mathrm{Cl}_{2}: \mathrm{MeOH}, 85: 15, v / v\right) ;[\alpha]_{\mathrm{D}}^{23}=+28(c=0.7$, pyridine); IR (film) 3333, 2917, 2850, 1605,1532 , 1488, 1467, 1377, 1321, 1281, 1229, 1172, 1145, 1075, 1037, 995, 943, 909, 841, $805 \mathrm{~cm}^{-}$ 1, ${ }^{1} \mathrm{H}-\mathrm{NMR}\left(500 \mathrm{MHz}, \mathrm{C}_{5} \mathrm{D}_{5} \mathrm{~N}\right) \delta 9.17$ (bt, $\left.J_{\mathrm{NH}, 6 \mathrm{a}}=J_{\mathrm{NH}, 6 \mathrm{~b}}=5.8 \mathrm{~Hz}, 2 \mathrm{H}, \mathrm{NH}\right), 7.59$ (H-2" or H-4"), 7.30 (t, $\left.J_{2 ", 3 "}=J_{3^{\prime \prime}, 4 "}=7.4 \mathrm{~Hz}, 4 \mathrm{H}, \mathrm{H}-3^{\prime \prime}\right), 7.20$ (H-2" or H-4"), 6.66 (bs, 2H, H-3'), 6.50 (bs, 2H, H-5'), 5.82 $\left(\mathrm{d}, J_{1,2}=3.3 \mathrm{~Hz}, 2 \mathrm{H}, \mathrm{H}-1\right), 5.21\left(\mathrm{~s}, 4 \mathrm{H}, \mathrm{CH}_{2}-O-\mathrm{Bn}\right), 5.06(\mathrm{~m}, 2 \mathrm{H}, \mathrm{H}-5), 4.76\left(\mathrm{t}, J_{2,3}=J_{3,4}=9.2 \mathrm{~Hz}, 2 \mathrm{H}\right.$, H-3), 4.56 (m, 2H, H-6a), 4.27-4.17 (m, 6H, H-2, H-4 \& H-6b), 3.91 (t, $J_{7^{\prime}, 8^{\prime}}=6.4$ Hz, 4H, H-7'), 2.53 (s, 6'-Me), 1.73 (p, $\left.J_{7^{\prime}, 8^{\prime}}=J_{8^{\prime}, 9^{\prime}}=7.0 \mathrm{~Hz}, 4 \mathrm{H}, \mathrm{H}-8^{\prime}\right), 1.43$ (m, 4H, H-9'), 1.35-1.19 (m, 56H, H-10'-H$\left.23^{\prime}\right), 0.88\left(\mathrm{t}, J_{23^{\prime}, 24^{\prime}}=6.8 \mathrm{~Hz}, 6 \mathrm{H}, \mathrm{H}-24^{\prime}\right) ;{ }^{13} \mathrm{C}-\mathrm{NMR}\left(150 \mathrm{MHz}, \mathrm{C}_{5} \mathrm{D}_{5} \mathrm{~N}\right) \delta 170.0(\mathrm{C}=\mathrm{O}), 161.0\left(\mathrm{C}-4^{\prime}\right)$, 157.5 (C-2'), 138.7, 138.4 (C-1' \& C-6'), 129.3, 128.4, 127.8 (C-2'-C-4'), 122.6 (C-1'), 108.7 (C-5'), 99.2 (C-3'), 96.7 (C-1), 74.6 (C-3), 74.0, 73.6 (C-2 \& C-4), 73.1 (C-5), $70.7\left(\mathrm{CH}_{2}-\mathrm{O}-\mathrm{Bn}\right), 68.7(\mathrm{C}-8)$, 42.0 (C-6), 32.6, 30.50, 30.48, 30.47, 30.42, 30.41, 30.2, 30.1 30.0, 26.8, 23.4 (C-9'-C-23'), 20.5 (6'Me), 14.8 (C-24'); HRMS (ESI) $\mathrm{m} / z[\mathrm{M}+\mathrm{H}]^{+}$calcd. for $\left[\mathrm{C}_{78} \mathrm{H}_{120} \mathrm{~N}_{2} \mathrm{O}_{15}+\mathrm{H}\right]^{+}$: 1325.8761, obsd.: 1325.8761 


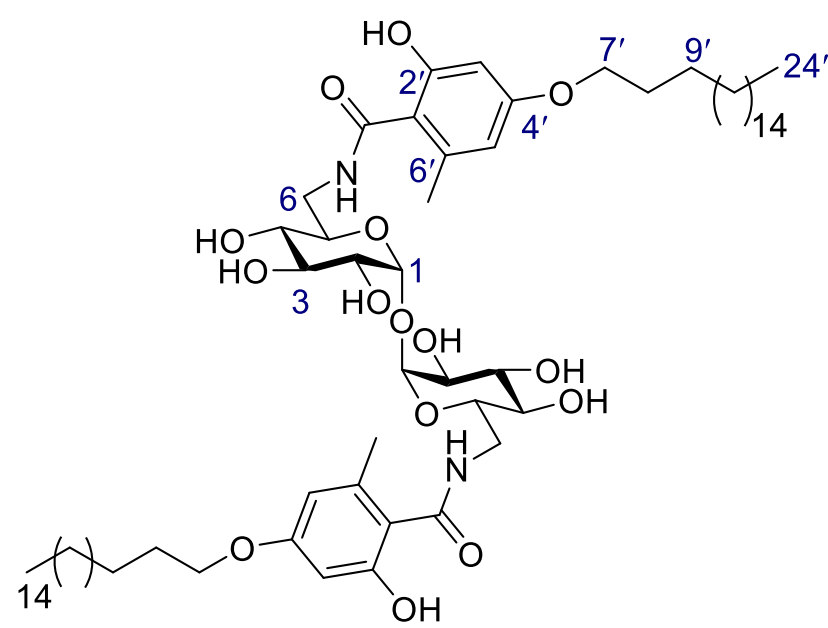

6,6'-Dideoxy-(2-hydroxy-6-methyl-4octadecyloxy-benzoylamide)- $\alpha, \alpha^{\prime}$-trehalose

(2c). To a solution of di-amide $38(36 \mathrm{mg}, 0.03$ mmol) in distilled $\mathrm{CH}_{2} \mathrm{Cl}_{2}: \mathrm{MeOH}(4 \mathrm{~mL}, 1: 1, v / v)$ was added $\mathrm{Pd}(\mathrm{OH})_{2} / \mathrm{C}(28 \mathrm{mg}) . \mathrm{H}_{2}$ was bubbled through the suspension for $20 \mathrm{~h}$, and then the reaction mixture was diluted with pyridine $(10$ $\mathrm{mL}$ ) and filtered over celite. The filtrate was concentrated and the resultant residue purified by

gradient silica gel flash column chromatography $\left(\mathrm{CH}_{2} \mathrm{Cl}_{2}\right.$ to $\left.\mathrm{CH}_{2} \mathrm{Cl}_{2}: \mathrm{MeOH}, 4: 1, v / v\right)$ to give the title compound as a pale orange-brown solid (16 mg, $0.01 \mathrm{mmol}, 53 \%) . \mathrm{R}_{f}=0.18\left(\mathrm{CH}_{2} \mathrm{Cl}_{2}: \mathrm{MeOH}, 85: 15\right.$, $v / v) ;[\alpha]_{\mathrm{D}}^{23}=+25(c=1.0$, pyridine); IR (film) 3350, 2916, 2849, 2765, 1607, 1539, 1467, 1318, 1275, 1213, 1174, 1144, 1106, 1059, 1037, 992, 945, 835, $804 \mathrm{~cm}^{-1} ;{ }^{1} \mathrm{H}-\mathrm{NMR}\left(500 \mathrm{MHz}, \mathrm{C}_{5} \mathrm{D}_{5} \mathrm{~N}\right) \delta 8.78(\mathrm{bt}$, $\left.J_{\mathrm{NH}, 6 \mathrm{a}}=J_{\mathrm{NH}, 6 \mathrm{~b}}=5.7 \mathrm{~Hz}, 2 \mathrm{H}, \mathrm{NH}\right), 6.75\left(\mathrm{~s}, 2 \mathrm{H}, \mathrm{H}-3^{\prime}\right), 6.50\left(\mathrm{~s}, 2 \mathrm{H}, \mathrm{H}-5^{\prime}\right), 5.84\left(\mathrm{~d}, J_{1,2}=3.7 \mathrm{~Hz}, 2 \mathrm{H}, \mathrm{H}-\right.$ 1), 5.08 (m, 2H, H-5), 4.73 (t, $J_{2,3}=J_{3,4}=9.0 \mathrm{~Hz}, 2 \mathrm{H}, \mathrm{H}-3$ ), 4.35 (m, 4H, H-6a \& H-6b), 2.34 (dd, $J_{2,3}$ $\left.=9.2 \mathrm{~Hz}, J_{1,2}=3.3 \mathrm{~Hz}, 2 \mathrm{H}, \mathrm{H}-2\right), 4.11\left(\mathrm{t}, J_{3,4}=J_{4,5}=9.2 \mathrm{~Hz}, 2 \mathrm{H}, \mathrm{H}-4\right), 3.94\left(\mathrm{t}, J_{7^{\prime}, 8^{\prime}}=6.4 \mathrm{~Hz}, 4 \mathrm{H}, \mathrm{H}-\right.$ 7'), 3.19 (m, 4H, H-8'), 2.70 (s, 6H, 6'-Me), 1.74 (m, 8H, H-9' \& H-10'), 1.48-1.13 (m, 52H, H-11'-H23'), $0.88\left(\mathrm{t}, J_{23^{\prime}, 24^{\prime}}=6.6 \mathrm{~Hz}, 6 \mathrm{H}, \mathrm{H}-24^{\prime}\right) ; 170.8(\mathrm{C}=\mathrm{O}), 161.7\left(\mathrm{C}-4^{\prime}\right), 160.3\left(\mathrm{C}-2^{\prime}\right), 139.8\left(\mathrm{C}-6^{\prime}\right), 116.8$ (C-1'), 109.4 (C-5'), 101.1 (C-3'), 96.8 (C-1), 74.8 (C-3), 74.2 (C-4), 73.9 (C-2), 72.7 (C-5), 68.5 (C7'), 44.6 (C-8'), 42.5 (C-6), 32.6, 30.5, 30.4 30.2, 30.1, 30.0, 26.8, 23.41, 23.38, 23.1 (C-9'-C-23'), 22.2 (6'-Me), 14.8 (C-24'); HRMS (ESI) $m / z[\mathrm{M}+\mathrm{H}]^{+}$calcd. for: $\left[\mathrm{C}_{64} \mathrm{H}_{108} \mathrm{~N}_{2} \mathrm{O}_{15}+\mathrm{H}\right]^{+}:$1145.7822, obsd.: 1145.7822 .

\subsection{Biological Methods.}

Trehalose amide glycolipids 1a-e, trehalose glycolipids 24a-d, and TDB were dissolved in $\mathrm{CHCl}_{3}: \mathrm{MeOH}(2: 1, v / v, 1 \mathrm{mM})$, diluted in isopropanol $(0.05 \mathrm{mM})$ and added to 96 -well plates $(0.1$ or $1 \mathrm{nmmol} /$ well). The solvents were evaporated, and the coated plates were used immediately. 2B4NFAT-GFP reporter cells expressing mMincle $+\mathrm{FcR} \gamma$, hMincle $+\mathrm{FcR} \gamma$, or FcR $\gamma$ only have previously been described, ${ }^{62}$ and were kindly gifted by S. Yamasaki (Osaka University, Japan). NFAT-GFP 2B4 reporter cells were incubated with ligand-coated plates $(0.1$ or $1 \mathrm{nmmol} /$ well $)$ for 18 hours. The reporter cells were harvested, stained with 4',6-diamidino-2-phenyolide (DAPI) and analysed for NFAT-GFP expression using flow-cytometry (FACS, Calibur). Experiments were kindly performed by A. J. Foster (Victoria University of Wellington). 


\section{References}

1. Mathers, C.; Fat, D. M.; Boerma, J. T., The global burden of disease: 2004 update. World Health Organization: 2008.

2. Morens, D. M.; Folkers, G. K.; Fauci, A. S., The challenge of emerging and re-emerging infectious diseases. Nature 2004, 430, 242-249.

3. Jones, K. E.; Patel, N. G.; Levy, M. A.; Storeygard, A.; Balk, D.; Gittleman, J. L.; Daszak, P., Global trends in emerging infectious diseases. Nature 2008, 451, 990-993.

4. Hilleman, M. R., Vaccines in historic evolution and perspective: a narrative of vaccine discoveries. Vaccine 2000, 18, 1436-1447.

5. $\quad$ Plotkin, S. A., Vaccines: past, present and future. Nat. Med. 2005, 11, S5-S11.

6. Böttiger, M.; Christenson, B.; Romanus, V.; Taranger, J.; Strandell, A., Swedish experience of two dose vaccination programme aiming at eliminating measles, mumps, and rubella. $\mathrm{Br}$. Med. J. (Clin. Res. Ed.) 1987, 295, 1264-1267.

7. Peltola, H.; Heinonen, O. P.; Valle, M.; Paunio, M.; Virtanen, M.; Karanko, V.; Cantell, K., The elimination of indigenous measles, mumps, and rubella from Finland by a 12 -year, twodose vaccination program. N. Engl. J. Med. 1994, 331, 1397-1402.

8. Christenson, B.; Böttiger, M., Changes of the immunological patterns against measles, mumps and rubella. A vaccination programme studied 3 to 7 years after the introduction of a two-dose schedule. Vaccine 1991, 9, 326-329.

9. White, C. C.; Koplan, J. P.; Orenstein, W. A., Benefits, risks and costs of immunization for measles, mumps and rubella. Am. J. Public Health 1985, 75, 739-744.

10. World Health Organization Global vaccine action plan 2011-2020; 9241504986; 2013.

11. Coltart, C. E. M.; Lindsey, B.; Ghinai, I.; Johnson, A. M.; Heymann, D. L., The Ebola outbreak, 2013-2016: old lessons for new epidemics. Phil. Trans. R. Soc. B 2017, 372.

12. Lambe, T.; Bowyer, G.; Ewer, K. J., A review of Phase I trials of Ebola virus vaccines: what can we learn from the race to develop novel vaccines? Phil. Trans. R. Soc. B 2017, 372.

13. Castellino, F.; Galli, G.; Del Giudice, G.; Rappuoli, R., Generating memory with vaccination. Eur. J. Immunol. 2009, 39, 2100-2105.

14. Theiler, M.; Smith, H. H., The use of yellow fever virus modified by in vitro cultivation for human immunization. J. Exp. Med. 1937, 65, 787-800.

15. Vaughan, A.; Wang, R.; Kappe, S. H. I., Genetically engineered, attenuated whole-cell vaccine approaches for malaria. Human Vaccines 2010, 6, 107-113.

16. Martín, C., The dream of a vaccine against tuberculosis; new vaccines improving or replacing BCG? Eur. Respir. J. 2005, 26, 162-167.

17. Perrie, Y.; Mohammed, A. R.; Kirby, D. J.; McNeil, S. E.; Bramwell, V. W., Vaccine adjuvant systems: Enhancing the efficacy of sub-unit protein antigens. Int. J. Pharm. 2008, 364, 272 280.

18. Murphy, K.; Weaver, C., Manipulation of the immune response. In Janeway's immunobiology, 9 ed.; Garland Sciene/Taylor \& Francis: New York, 2016.

19. Crotty, S.; Felgner, P.; Davies, H.; Glidewell, J.; Villarreal, L.; Ahmed, R., Cutting Edge: Long-Term B Cell Memory in Humans after Smallpox Vaccination. J. Immunol. 2003, 171, 4969-4973.

20. Plotkin, S. A., Correlates of Protection Induced by Vaccination. Clin. Vaccine Immunol. 2010, 17, 1055-1065.

21. Buisman, A. M.; de Rond, C. G. H.; Öztürk, K.; ten Hulscher, H. I.; van Binnendijk, R. S., Long-term presence of memory B-cells specific for different vaccine components. Vaccine 2009, 28, 179-186. 
22. Murphy, K.; Weaver, C., The humoral immune response. In Janeway's immunobiology, 9 ed.; Garland Science/Taylor \& Francis: New York, 2016.

23. Murphy, K.; Weaver, C., T-cell-mediated immunity. In Janeway's immunobiology, 9 ed.; Garland Science/Taylor \& Francis: New York, 2016.

24. Hammarlund, E.; Lewis, M. W.; Hansen, S. G.; Strelow, L. I.; Nelson, J. A.; Sexton, G. J.; Hanifin, J. M.; Slifka, M. K., Duration of antiviral immunity after smallpox vaccination. Nat. Med. 2003, 9, 1131.

25. Delany, I.; Rappuoli, R.; De Gregorio, E., Vaccines for the 21st century. EMBO Mol. Med. 2014, 6, 708 .

26. Lin, Y.; Slight, S. R.; Khader, S. A. In Th17 cytokines and vaccine-induced immunity, Seminars in immunopathology, Springer: 2010; pp 79-90.

27. Coffman, R. L.; Sher, A.; Seder, R. A., Vaccine Adjuvants: Putting Innate Immunity to Work. Immunity 2010, 33, 492-503.

28. Murphy, K.; Weaver, C., Basic concepts in immunology. In Janeway's immunobiology, 9 ed.; Garland Science/Taylor \& Francis: New York, 2016.

29. Hoebe, K.; Janssen, E.; Beutler, B., The interface between innate and adaptive immunity. Nat. Immunol. 2004, 5, 971-974.

30. Lang, R.; Schoenen, H.; Desel, C., Targeting Syk-Card9-activating C-type lectin receptors by vaccine adjuvants: Findings, implications and open questions. Immunobiol. 2011, 216, 11841191.

31. Querec, T.; Bennouna, S.; Alkan, S.; Laouar, Y.; Gorden, K.; Flavell, R.; Akira, S.; Ahmed, R.; Pulendran, B., Yellow fever vaccine YF-17D activates multiple dendritic cell subsets via TLR2, 7, 8, and 9 to stimulate polyvalent immunity. J. Exp. Med. 2006, 203, 413-424.

32. Oleszycka, E.; Lavelle, E. C., Immunomodulatory properties of the vaccine adjuvant alum. Curr. Opin. Immunol. 2014, 28, 1-5.

33. Caroff, M.; Karibian, D., Structure of bacterial lipopolysaccharides. Carbohydr. Res. 2003, 338, 2431-2447.

34. Rao, M.; Peachman, K. K.; Li, Q.; Matyas, G. R.; Shivachandra, S. B.; Borschel, R.; Morthole, V. I.; Fernandez-Prada, C.; Alving, C. R.; Rao, V. B., Highly effective generic adjuvant systems for orphan or poverty-related vaccines. Vaccine 2011, 29, 873-877.

35. Alving, C. R.; Rao, M.; Steers, N. J.; Matyas, G. R.; Mayorov, A. V., Liposomes containing lipid A: an effective, safe, generic adjuvant system for synthetic vaccines. Expert Rev. Vaccines 2012, 11, 733-744.

36. Szarewski, A., Cervarix $®$ : a bivalent vaccine against HPV types 16 and 18, with crossprotection against other high-risk HPV types. Expert Rev. Vaccines 2012, 11, 645-57.

37. Khan, A. A.; Stocker, B. L.; Timmer, M. S. M., Trehalose glycolipids-synthesis and biological activities. Carbohydr. Res. 2012, 356, 25-36.

38. Rosenkrands, I.; Agger, E. M.; Olsen, A. W.; Korsholm, K. S.; Andersen, C. S.; Jensen, K. T.; Andersen, P., Cationic Liposomes Containing Mycobacterial Lipids: a New Powerful Th1 Adjuvant System. Infect. Immun. 2005, 73, 5817-5826.

39. Holten-Andersen, L.; Doherty, T. M.; Korsholm, K. S.; Andersen, P., Combination of the Cationic Surfactant Dimethyl Dioctadecyl Ammonium Bromide and Synthetic Mycobacterial Cord Factor as an Efficient Adjuvant for Tuberculosis Subunit Vaccines. Infect. Immun. 2004, 72, 1608-1617.

40. Bloch, H., Studies on the virulence of Tubercle bacilli. J. Exp. Med. 1950, 91, 197.

41. Agger, E. M.; Rosenkrands, I.; Hansen, J.; Brahimi, K.; Vandahl, B. S.; Aagaard, C.; Werninghaus, K.; Kirschning, C.; Lang, R.; Christensen, D.; Theisen, M.; Follmann, F.; Andersen, P., Cationic Liposomes Formulated with Synthetic Mycobacterial Cordfactor (CAF01): A Versatile Adjuvant for Vaccines with Different Immunological Requirements. PLOS ONE 2008, 3, e3116. 
42. Román, V. R. G.; Jensen, K. J.; Jensen, S. S.; Leo-Hansen, C.; Jespersen, S.; Té, D. d. S.; Rodrigues, C. M.; Janitzek, C. M.; Vinner, L.; Katzenstein, T. L., Therapeutic vaccination using cationic liposome-adjuvanted HIV type 1 peptides representing HLA-supertyperestricted subdominant $\mathrm{T}$ cell epitopes: safety, immunogenicity, and feasibility in GuineaBissau. AIDS Res. Hum. Retroviruses 2013, 29, 1504-1512.

43. Welsh, K. J.; Hunter, R. L.; Actor, J. K., Trehalose 6,6'-dimycolate - A coat to regulate tuberculosis immunopathogenesis. Tuberculosis 2013, 93, S3-S9.

44. Penkov, S.; Mende, F.; Zagoriy, V.; Erkut, C.; Martin, R.; Pässler, U.; Schuhmann, K.; Schwudke, D.; Gruner, M.; Mäntler, J.; Reichert-Müller, T.; Shevchenko, A.; Knölker, H.-J.; Kurzchalia, T. V., Maradolipids: Diacyltrehalose Glycolipids Specific to Dauer Larva in Caenorhabditis elegans. Angew. Chem. Int. Ed. 2010, 49, 9430-9435.

45. Nobre, A.; Alarico, S.; Maranha, A.; Mendes, V.; Empadinhas, N., The molecular biology of mycobacterial trehalose in the quest for advanced tuberculosis therapies. Microbiology UK 2014, 160, 1547-1570.

46. Ioneda, T.; Lenz, M.; Pudles, J., Chemical constitution of a glycolipid from C. diptheriae P.W.8. Biochem. Biophys. Res. Commun. 1963, 13, $110-114$.

47. Puzo, G.; Tissié, G.; Aurelle, H.; Lacave, C.; Jean-Claude, P.; eacute, Occurrence of 3-Oxoacyl Groups in the 6,6'-Diesters of $\alpha$-D-Trehalose. Eur. J. Biochem. 1979, 98, 99-105.

48. Watanabe, M.; Aoyagi, Y.; Mitome, H.; Fujita, T.; Naoki, H.; Ridell, M.; Minnikin, D. E., Location of functional groups in mycobacterial meromycolate chains; the recognition of new structural principles in mycolic acids. Microbiology 2002, 148, 1881-1902.

49. Khan, A. A.; Chee, S. H.; McLaughlin, R. J.; Harper, J. L.; Kamena, F.; Timmer, M. S. M.; Stocker, B. L., Long-Chain Lipids Are Required for the Innate Immune Recognition of Trehalose Diesters by Macrophages. ChemBioChem 2011, 12, 2572-2576.

50. Braganza, C. D.; Teunissen, T.; Timmer, M. S. M.; Stocker, B. L., Identification and Biological Activity of Synthetic Macrophage Inducible C-Type Lectin Ligands. Front. Immunol. 2018, 8, 1940.

51. Indrigo, J.; Hunter, R. L.; Actor, J. K., Influence of trehalose 6,6'-dimycolate (TDM) during mycobacterial infection of bone marrow macrophages. Microbiology 2002, 148, 1991-1998.

52. Perez, R. L.; Roman, J.; Roser, S.; Little, C.; Olsen, M.; Indrigo, J.; Hunter, R. L.; Actor, J. K., Cytokine message and protein expression during lung granuloma formation and resolution induced by the mycobacterial cord factor trehalose-6,6'-dimycolate. J. Interferon Cytokine Res. 2000, 20, 795-804.

53. Geisel, R. E.; Sakamoto, K.; Russell, D. G.; Rhoades, E. R., In Vivo Activity of Released Cell Wall Lipids of Mycobacterium bovis Bacillus Calmette-Guérin Is Due Principally to Trehalose Mycolates. J. Immunol. 2005, 174, 5007-5015.

54. Numata, F.; Nishimura, K.; Ishida, H.; Ukei, S.; Tone, Y.; Ishihara, C.; Saiki, I.; Sekikawa, I.; Azuma, I., Lethal and Adjuvant Activities of Cord Factor (Trehalose-6, 6'-dimycolate) and Synthetic Analogs in Mice. Chem. Pharm. Bull. 1985, 33, 4544-4555.

55. Hunter, R. L.; Olsen, M. R.; Jagannath, C.; Actor, J. K., Multiple Roles of Cord Factor in the Pathogenesis of Primary, Secondary, and Cavitary Tuberculosis, Including a Revised Description of the Pathology of Secondary Disease. Ann. Clin. Lab Sci. 2006, 36, 371-386.

56. Desel, C.; Werninghaus, K.; Ritter, M.; Jozefowski, K.; Wenzel, J.; Russkamp, N.; Schleicher, U.; Christensen, D.; Wirtz, S.; Kirschning, C.; Agger, E. M.; Costa, C. P.; Lang, R., The Mincle-Activating Adjuvant TDB Induces MyD88-Dependent Th1 and Th17 Responses through IL-1R Signaling. PLoS One 2013, 8, e53531.

57. Lindenstrøm, T.; Agger, E. M.; Korsholm, K. S.; Darrah, P. A.; Aagaard, C.; Seder, R. A.; Rosenkrands, I.; Andersen, P., Tuberculosis Subunit Vaccination Provides Long-Term Protective Immunity Characterized by Multifunctional CD4 Memory T Cells. J. Immunol. 2009, 182, 8047-8055. 
58. Lindenstrøm, T.; Woodworth, J.; Dietrich, J.; Aagaard, C.; Andersen, P.; Agger, E. M., Vaccine-Induced Th17 Cells Are Maintained Long-Term Postvaccination as a Distinct and Phenotypically Stable Memory Subset. Infect. Immun. 2012, 80, 3533-3544.

59. Stockinger, B.; Veldhoen, M., Differentiation and function of Th17 T cells. Curr. Opin. Immunol. 2007, 19, 281-286.

60. Ishikawa, E.; Ishikawa, T.; Morita, Y. S.; Toyonaga, K.; Yamada, H.; Takeuchi, O.; Kinoshita, T.; Akira, S.; Yoshikai, Y.; Yamasaki, S., Direct recognition of the mycobacterial glycolipid, trehalose dimycolate, by C-type lectin Mincle. J. Exp. Med. 2009, 206, 2879-2888.

61. Schoenen, H.; Bodendorfer, B.; Hitchens, K.; Manzanero, S.; Werninghaus, K.; Nimmerjahn, F.; Agger, E. M.; Stenger, S.; Andersen, P.; Ruland, J.; Brown, G. D.; Wells, C.; Lang, R., Cutting Edge: Mincle Is Essential for Recognition and Adjuvanticity of the Mycobacterial Cord Factor and its Synthetic Analog Trehalose-Dibehenate. J. Immunol. 2010, 184, 2756-2760.

62. Yamasaki, S.; Ishikawa, E.; Sakuma, M.; Hara, H.; Ogata, K.; Saito, T., Mincle is an ITAMcoupled activating receptor that senses damaged cells. Nat. Immunol. 2008, 9, 1179-1188.

63. Werninghaus, K.; Babiak, A.; Groß, O.; Hölscher, C.; Dietrich, H.; Agger, E. M.; Mages, J.; Mocsai, A.; Schoenen, H.; Finger, K.; Nimmerjahn, F.; Brown, G. D.; Kirschning, C.; Heit, A.; Andersen, P.; Wagner, H.; Ruland, J.; Lang, R., Adjuvanticity of a synthetic cord factor analogue for subunit Mycobacterium tuberculosis vaccination requires FcR $\gamma-\mathrm{Syk}-\mathrm{Card} 9$ dependent innate immune activation. J. Exp. Med. 2009, 206, 89-97.

64. Richardson, M. B.; Williams, S. J., MCL and Mincle: C-type lectin receptors that sense damaged self and pathogen-associated molecular patterns. Front. Immunol. 2014, 5.

65. Furukawa, A.; Kamishikiryo, J.; Mori, D.; Toyonaga, K.; Okabe, Y.; Toji, A.; Kanda, R.; Miyake, Y.; Ose, T.; Yamasaki, S., Structural analysis for glycolipid recognition by the C-type lectins Mincle and MCL. Proc. Natl. Acad. Sci. U.S.A 2013, 110, 17438-17443.

66. Feinberg, H.; Jégouzo, S. A. F.; Rowntree, T. J. W.; Guan, Y.; Brash, M. A.; Taylor, M. E.; Weis, W. I.; Drickamer, K., Mechanism for recognition of an unusual mycobacterial glycolipid by the macrophage receptor mincle. J. Biol. Chem. 2013, 288, 28457-28465.

67. Feinberg, H.; Rambaruth, N. D. S.; Jégouzo, S. A. F.; Jacobsen, K. M.; Djurhuus, R.; Poulsen, T. B.; Weis, W. I.; Taylor, M. E.; Drickamer, K., Binding Sites for Acylated Trehalose Analogs of Glycolipid Ligands on an Extended Carbohydrate Recognition Domain of the Macrophage Receptor Mincle. J. Biol. Chem. 2016, 291, 21222-21233.

68. Khan, A.; Kodar, K.; Timmer, M. S. M.; Stocker, B. L., Lipid length and iso-branching of trehalose diesters influences Mincle agonist activity. Tetrahedron 2017, Article in Press, doi:10.1016/j.tet.2017.11.076.

69. Huber, A.; Kallerup, R. S.; Korsholm, K. S.; Franzyk, H.; Lepenies, B.; Christensen, D.; Foged, C.; Lang, R., Trehalose diester glycolipids are superior to the monoesters in binding to Mincle, activation of macrophages in vitro and adjuvant activity in vivo. Innate Immunity 2016, 22, 405-418.

70. Stocker, B. L.; Khan, A. A.; Chee, S. H.; Kamena, F.; Timmer, M. S. M., On one leg: Trehalose monoesters activate macrophages in a mincle-dependant manner. ChemBioChem 2014, 15, 382-388.

71. Tima, H. G.; Al Dulayymi, J. R.; Denis, O.; Lehebel, P.; Baols, K. S.; Mohammed, M. O.; L'Homme, L.; Sahb, M. M.; Potemberg, G.; Legrand, S.; Lang, R.; Beyaert, R.; Piette, J.; Baird, M. S.; Huygen, K.; Romano, M., Inflammatory Properties and Adjuvant Potential of Synthetic Glycolipids Homologous to Mycolate Esters of the Cell Wall of Mycobacterium tuberculosis. J. Innate Immun. 2017, 9, 162-180.

72. Yamasaki, S.; Matsumoto, M.; Takeuchi, O.; Matsuzawa, T.; Ishikawa, E.; Sakuma, M.; Tateno, H.; Uno, J.; Hirabayashi, J.; Mikami, Y.; Takeda, K.; Akira, S.; Saito, T., C-type lectin Mincle is an activating receptor for pathogenic fungus, Malassezia. Proc. Natl. Acad. Sci. U.S.A 2009, 106, 1897-1902. 
73. Ishikawa, T.; Itoh, F.; Yoshida, S.; Saijo, S.; Matsuzawa, T.; Gonoi, T.; Saito, T.; Okawa, Y.; Shibata, N.; Miyamoto, T.; Yamasaki, S., Identification of distinct ligands for the C-type lectin receptors mincle and dectin-2 in the pathogenic fungus Malassezia. Cell Host Microbe 2013, 13, 477-488.

74. Hattori, Y.; Morita, D.; Fujiwara, N.; Mori, D.; Nakamura, T.; Harashima, H.; Yamasaki, S.; Sugita, M., Glycerol monomycolate is a novel ligand for the human, but not mouse macrophage inducible C-type lectin, Mincle. J. Biol. Chem. 2014, 289, 15405-15412.

75. Nagata, M.; Izumi, Y.; Ishikawa, E.; Kiyotake, R.; Doi, R.; Iwai, S.; Omahdi, Z.; Yamaji, T.; Miyamoto, T.; Bamba, T.; Yamasaki, S., Intracellular metabolite $\beta$-glucosylceramide is an endogenous Mincle ligand possessing immunostimulatory activity. Proc. Natl. Acad. Sci. U.S.A 2017, 114, E3285-E3294.

76. Igarashi, Y.; Mogi, T.; Yanase, S.; Miyanaga, S.; Fujita, T.; Sakurai, H.; Saiki, I.; Ohsaki, A., Brartemicin, an Inhibitor of Tumor Cell Invasion from the Actinomycete Nonomuraea sp. Journal of Natural Products 2009, 72, 980-982.

77. Jacobsen, K. M.; Keiding, U. B.; Clement, L. L.; Schaffert, E. S.; Rambaruth, N. D. S.; Johannsen, M.; Drickamer, K.; Poulsen, T. B., The natural product brartemicin is a high affinity ligand for the carbohydrate-recognition domain of the macrophage receptor mincle. MedChemComm 2015, 6, 647-652.

78. Kiyotake, R.; Oh-Hora, M.; Ishikawa, E.; Miyamoto, T.; Ishibashi, T.; Yamasaki, S., Human mincle binds to cholesterol crystals and triggers innate immune responses. J. Biol. Chem. 2015, 290, 25322-25332.

79. Kostarnoy, A. V.; Gancheva, P. G.; Lepenies, B.; Tukhvatulin, A. I.; Dzharullaeva, A. S.; Polyakov, N. B.; Grumov, D. A.; Egorova, D. A.; Kulibin, A. Y.; Bobrov, M. A.; Malolina, E. A.; Zykin, P. A.; Soloviev, A. I.; Riabenko, E.; Maltseva, D. V.; Sakharov, D. A.; Tonevitsky, A. G.; Verkhovskaya, L. V.; Logunov, D. Y.; Naroditsky, B. S.; Gintsburg, A. L., Receptor Mincle promotes skin allergies and is capable of recognizing cholesterol sulfate. Proc. Natl. Acad. Sci. U.S.A 2017, 114, E2758-E2765.

80. Miyake, Y.; Toyonaga, K.; Mori, D.; Kakuta, S.; Hoshino, Y.; Oyamada, A.; Yamada, H.; Ono, K.-i.; Suyama, M.; Iwakura, Y.; Yoshikai, Y.; Yamasaki, S., C-type Lectin MCL Is an FcR $\gamma$ Coupled Receptor that Mediates the Adjuvanticity of Mycobacterial Cord Factor. Immunity 2013, 38, 1050-1062.

81. Zhao, X.-Q.; Zhu, L.-L.; Chang, Q.; Jiang, C.; You, Y.; Luo, T.; Jia, X.-M.; Lin, X., C-type lectin receptor dectin-3 mediates trehalose 6, 6'-dimycolate (TDM)-induced Mincle expression through CARD9/Bcl10/MALT1-dependent nuclear factor (NF)- $\kappa \mathrm{B}$ activation. J. Biol. Chem. 2014, 289, 30052-30062.

82. Graham, L. M.; Gupta, V.; Schafer, G.; Reid, D. M.; Kimberg, M.; Dennehy, K. M.; Hornsell, W. G.; Guler, R.; Campanero-Rhodes, M. A.; Palma, A. S.; Feizi, T.; Kim, S. K.; Sobieszczuk, P.; Willment, J. A.; Brown, G. D., The C-type Lectin Receptor CLECSF8 (CLEC4D) Is Expressed by Myeloid Cells and Triggers Cellular Activation through Syk Kinase. J. Biol. Chem. 2012, 287, 25964-25974.

83. Miyake, Y.; Oh-hora, M.; Yamasaki, S., C-Type Lectin Receptor MCL Facilitates Mincle Expression and Signaling through Complex Formation. J. Immunol. 2015, 194, 5366-5374.

84. Lobato-Pascual, A.; Saether, P. C.; Fossum, S.; Dissen, E.; Daws, M. R., Mincle, the receptor for mycobacterial cord factor, forms a functional receptor complex with MCL and FceRI- $\gamma$. Eur. J. Immunol. 2013, 43, 3167-3174.

85. Waterman, K. C.; Adami, R. C.; Alsante, K. M.; Antipas, A. S.; Arenson, D. R.; Carrier, R.; Hong, J.; Landis, M. S.; Lombardo, F.; Shah, J. C.; Shalaev, E.; Smith, S. W.; Wang, H., Hydrolysis in Pharmaceutical Formulations. Pharm. Dev. Technol. 2002, 7, 113-146.

86. Testa, B.; Krämer, S. D., The Biochemistry of Drug Metabolism - An Introduction. Chem. Biodivers. 2007, 4, 2031-2122. 
87. Carey, F. A.; Sundberg, R. J., Addition, condensation and substitution reactions of carbonyl compounds. In Advanced Organic Chemistry Part A: Structure and Mechanisms, 5 ed.; Springer: 2007; pp 629-711.

88. Kahne, D.; Still, W. C., Hydrolysis of a peptide bond in neutral water. J. Am. Chem. Soc. 1988, 110, 7529-7534.

89. Kodar, K.; Eising, S.; Khan, A. A.; Steiger, S.; Harper, J. L.; Timmer, M. S. M.; Stocker, B. L., The uptake of trehalose glycolipids by macrophages is independent of mincle. ChemBioChem 2015, 16, 683-693.

90. Jiang, Y.-L.; Li, S.-X.; Liu, Y.-J.; Ge, L.-P.; Han, X.-Z.; Liu, Z.-P., Synthesis and Evaluation of Trehalose-Based Compounds as Novel Inhibitors of Cancer Cell Migration and Invasion. Chem. Biol. Drug Des. 2015, 86, 1017-1029.

91. Foley, H. N.; Stewart, J. A.; Kavunja, H. W.; Rundell, S. R.; Swarts, B. M., Bioorthogonal Chemical Reporters for Selective In Situ Probing of Mycomembrane Components in Mycobacteria. Angew. Chem. Int. Ed. 2016, 55, 2053-2057.

92. Foster, A. J.; Nagata, M.; Lu, X.; Lynch, A. T.; Omahdi, Z.; Ishikawa, E.; Yamasaki, S.; Timmer, M. S. M.; Stocker, B. L., Lipidated Brartemicin Analogues Are Potent Th1Stimulating Vaccine Adjuvants. Journal of Medicinal Chemistry 2017, Article in Press, doi:10.1021/acs.jmedchem.7b01468.

93. García Fernández, J.; Ortiz Mellet, C.; Jiménez Blanco, J.; Fuentes Mota, J.; Gadelle, A.; Coste-Sarguet, A.; Defaye, J., Isothiocyanates and cyclic thiocarbamates of $\alpha, \alpha^{\prime}$-trehalose, sucrose, and cyclomaltooligosaccharides. Carbohydr. Res. 1995, 268, 57-71.

94. Garegg, P. J.; Samuelsson, B., Novel reagent system for converting a hydroxy-group into an iodo-group in carbohydrates with inversion of configuration. J. Chem. Soc., Chem. Commun. 1979, 978-980.

95. El-Faham, A.; Albericio, F., Peptide Coupling Reagents, More than a Letter Soup. Chem. Rev. 2011, 111, 6557-6602.

96. Twibanire, J.-d. A. K.; Grindley, T. B., Efficient and Controllably Selective Preparation of Esters Using Uronium-Based Coupling Agents. Org. Lett. 2011, 13, 2988-2991.

97. Paul, N. K.; Twibanire, J.-d. A. K.; Grindley, T. B., Direct Synthesis of Maradolipids and Other Trehalose 6-Monoesters and 6,6'-Diesters. J. Org. Chem. 2013, 78, 363-369.

98. Srinivasachari, S.; Liu, Y.; Zhang, G.; Prevette, L.; Reineke, T. M., Trehalose Click Polymers Inhibit Nanoparticle Aggregation and Promote pDNA Delivery in Serum. J. Am. Chem. Soc. 2006, 128, 8176-8184.

99. Reineke, T. M.; Davis, M. E., Structural Effects of Carbohydrate-Containing Polycations on Gene Delivery. 1. Carbohydrate Size and Its Distance from Charge Centers. Bioconjugate Chem. 2003, 14, 247-254.

100. Ma, M.; Chatterjee, S.; Zhang, M.; Bong, D., Stabilization of vesicular and supported membranes by glycolipid oxime polymers. Chem. Commun. 2011, 47, 2853-2855.

101. Koga, K.; Ishida, K.; Yamada, T.; Yuan, D.-Q.; Fujita, K., Molecular sugar bowl: $\gamma-$ cyclodextrin with a disaccharide floor. Tetrahedron Lett. 1999, 40, 923-926.

102. Staudinger, H.; Meyer, J., Über neue organische Phosphorverbindungen III. Phosphinmethylenderivate und Phosphinimine. Helv. Chim. Acta 1919, 2, 635-646.

103. Gololobov, Y. G.; Kasukhin, L. F., Recent advances in the staudinger reaction. Tetrahedron 1992, 48, 1353-1406.

104. Sletten, E. M.; Bertozzi, C. R., From Mechanism to Mouse: A Tale of Two Bioorthogonal Reactions. Accounts of Chemical Research 2011, 44, 666-676.

105. Saxon, E.; Bertozzi, C. R., Cell surface engineering by a modified staudinger reaction. Science 2000, 287, 2007-10. 
106. Pratt, D. A.; Tallman, K. A.; Porter, N. A., Free Radical Oxidation of Polyunsaturated Lipids: New Mechanistic Insights and the Development of Peroxyl Radical Clocks. Accounts of Chemical Research 2011, 44, 458-467.

107. Porter, N. A.; Caldwell, S. E.; Mills, K. A., Mechanisms of free radical oxidation of unsaturated lipids. Lipids 1995, 30, 277-290.

108. Porter, N. A., Mechanisms for the autoxidation of polyunsaturated lipids. Accounts of Chemical Research 1986, 19, 262-268.

109. Valeur, E.; Bradley, M., Amide bond formation: beyond the myth of coupling reagents. Chem. Soc. Rev. 2009, 38, 606-631.

110. Johnson, D. A., Simple procedure for the preparation of trimethylsilyl ethers of carbohydrates and alcohols. Carbohydr. Res. 1992, 237, 313-318.

111. Prabhakar, S.; Vives, T.; Ferrieres, V.; Benvegnu, T.; Legentil, L.; Lemiegre, L., A fully enzymatic esterification/transesterification sequence for the preparation of symmetrical and unsymmetrical trehalose diacyl conjugates. Green Chem. 2017, 19, 987-995.

112. Csuk, R.; Schultheiß, A.; Sommerwerk, S.; Kluge, R., Synthesis of a maradolipid without using protecting groups. Tetrahedron Lett. 2013, 54, 2274-2276.

113. Pässler, U.; Gruner, M.; Penkov, S.; Kurzchalia, T. V.; Knölker, H.-J., Synthesis of Ten Members of the Maradolipid Family; Novel Diacyltrehalose Glycolipids from Caenorhabditis elegans. Synlett 2011, 2011, 2482-2486.

114. Ohtsuka, M.; Arase, H.; Takeuchi, A.; Yamasaki, S.; Shiina, R.; Suenaga, T.; Sakurai, D.; Yokosuka, T.; Arase, N.; Iwashima, M.; Kitamura, T.; Moriya, H.; Saito, T.; Crabtree, G. R., NFAM1, an Immunoreceptor Tyrosine-Based Activation Motif-Bearing Molecule That Regulates B Cell Development and Signaling. Proc. Natl. Acad. Sci. U.S.A 2004, 101, 81268131.

115. Richardson, M. B.; Torigoe, S.; Yamasaki, S.; Williams, S. J., Mycobacterium tuberculosis $\beta$ gentiobiosyl diacylglycerides signal through the pattern recognition receptor Mincle: total synthesis and structure activity relationships. Chem. Commun. 2015, 51, 15027-15030.

116. van der Peet, P. L.; Gunawan, C.; Torigoe, S.; Yamasaki, S.; Williams, S. J., Corynomycolic acid-containing glycolipids signal through the pattern recognition receptor Mincle. Chem. Commun. 2015, 51, 5100-5103.

117. Feinberg, H.; Rambaruth, N. D. S.; Jégouzo, S. A. F.; Jacobsen, K. M.; Djurhuus, R.; Poulsen, T. B.; Weis, W. I.; Taylor, M. E.; Drickamer, K., Binding sites for acylated trehalose analogs of glycolipid ligands on an extended carbohydrate-recognition domain of the macrophage receptor mincle. J. Biol. Chem. 2016.

118. Baird, L. J.; Timmer, M. S. M.; Teesdale-Spittle, P. H.; Harvey, J. E., Total Synthesis of Aigialomycin D Using a Ramberg-Bäcklund/RCM Strategy. J. Org. Chem. 2009, 74, 22712277.

119. Behler-Janbeck, F.; Takano, T.; Maus, R.; Stolper, J.; Jonigk, D.; Tort Tarrés, M.; Fuehner, T.; Prasse, A.; Welte, T.; Timmer, M. S. M.; Stocker, B. L.; Nakanishi, Y.; Miyamoto, T.; Yamasaki, S.; Maus, U. A., C-type Lectin Mincle Recognizes Glucosyl-diacylglycerol of Streptococcus pneumoniae and Plays a Protective Role in Pneumococcal Pneumonia. PLOS Pathogens 2016, 12, e1006038. 
Appendix - NMR Spectra 

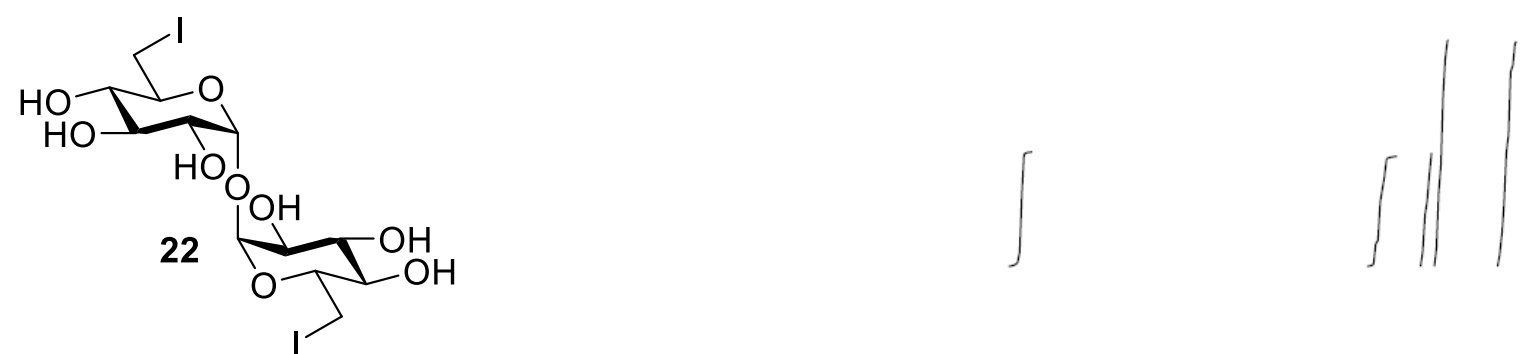

${ }^{1} \mathrm{H}-\mathrm{NMR}\left(500 \mathrm{MHz}, \mathrm{D}_{2} \mathrm{O}\right)$

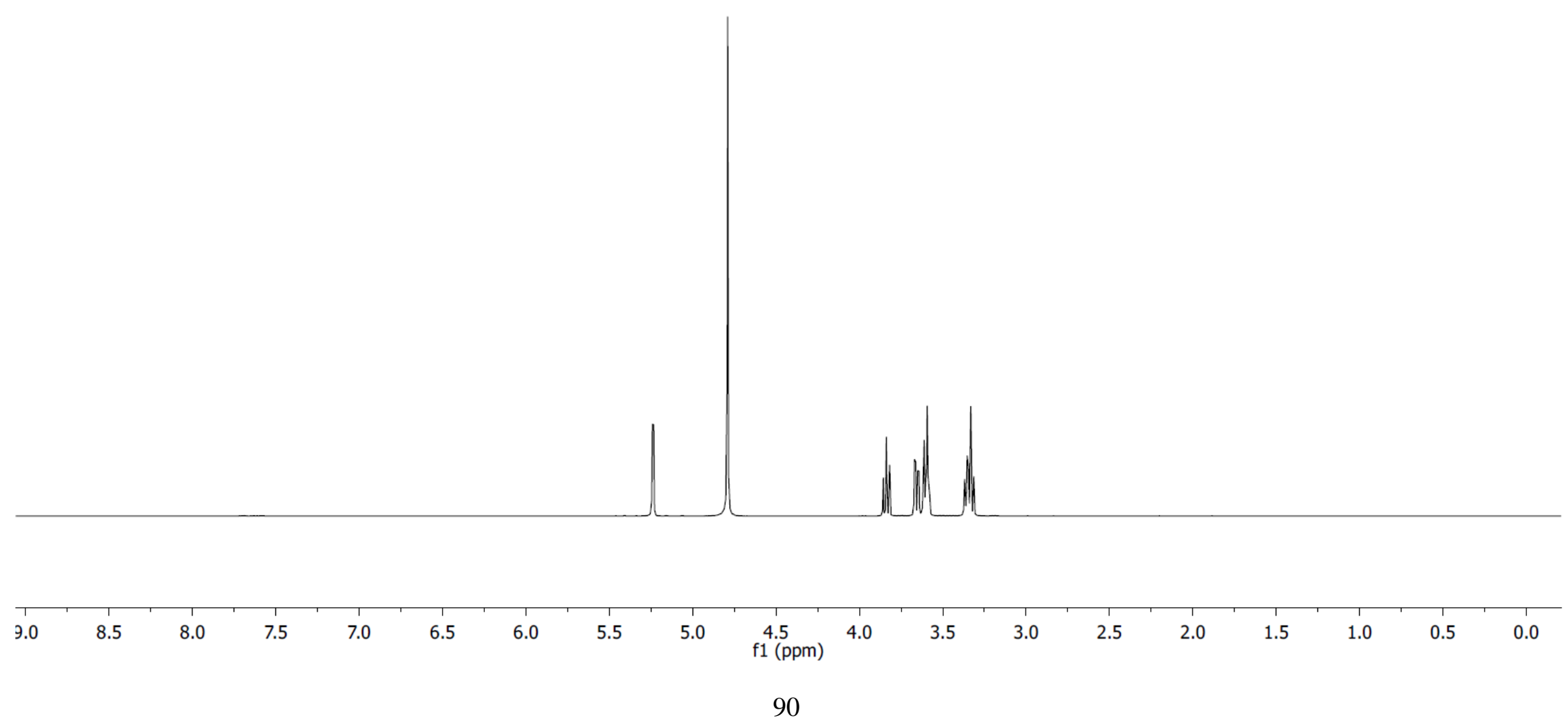




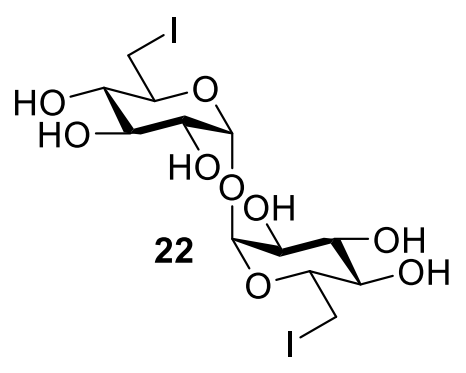

${ }^{13} \mathrm{C}-\mathrm{NMR}\left(125 \mathrm{MHz}, \mathrm{D}_{2} \mathrm{O}\right)$

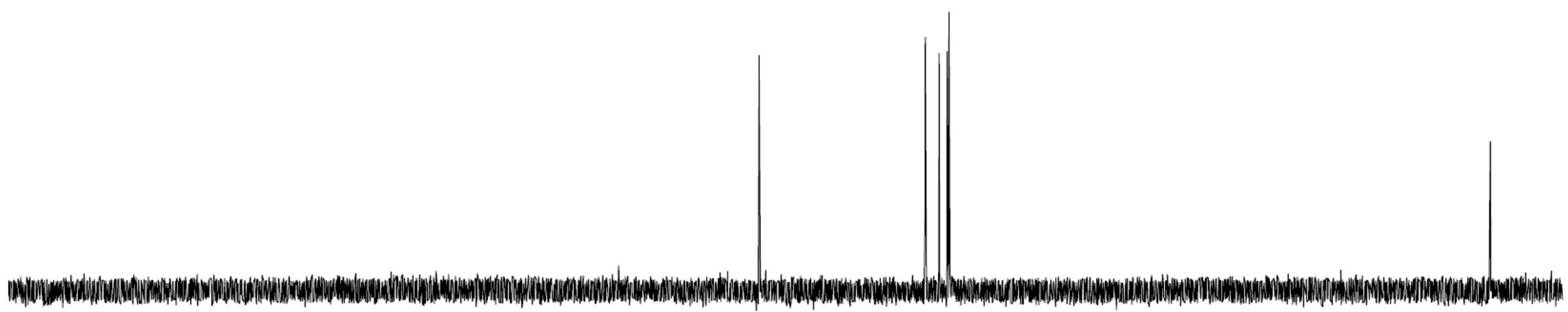

$180 \quad 170$

160

150

140

130

120

110

100

$\stackrel{90}{9}$

80

$70 \quad 60$

50

40 $\begin{array}{rrrr}1 & 1 & 1\end{array}$ 


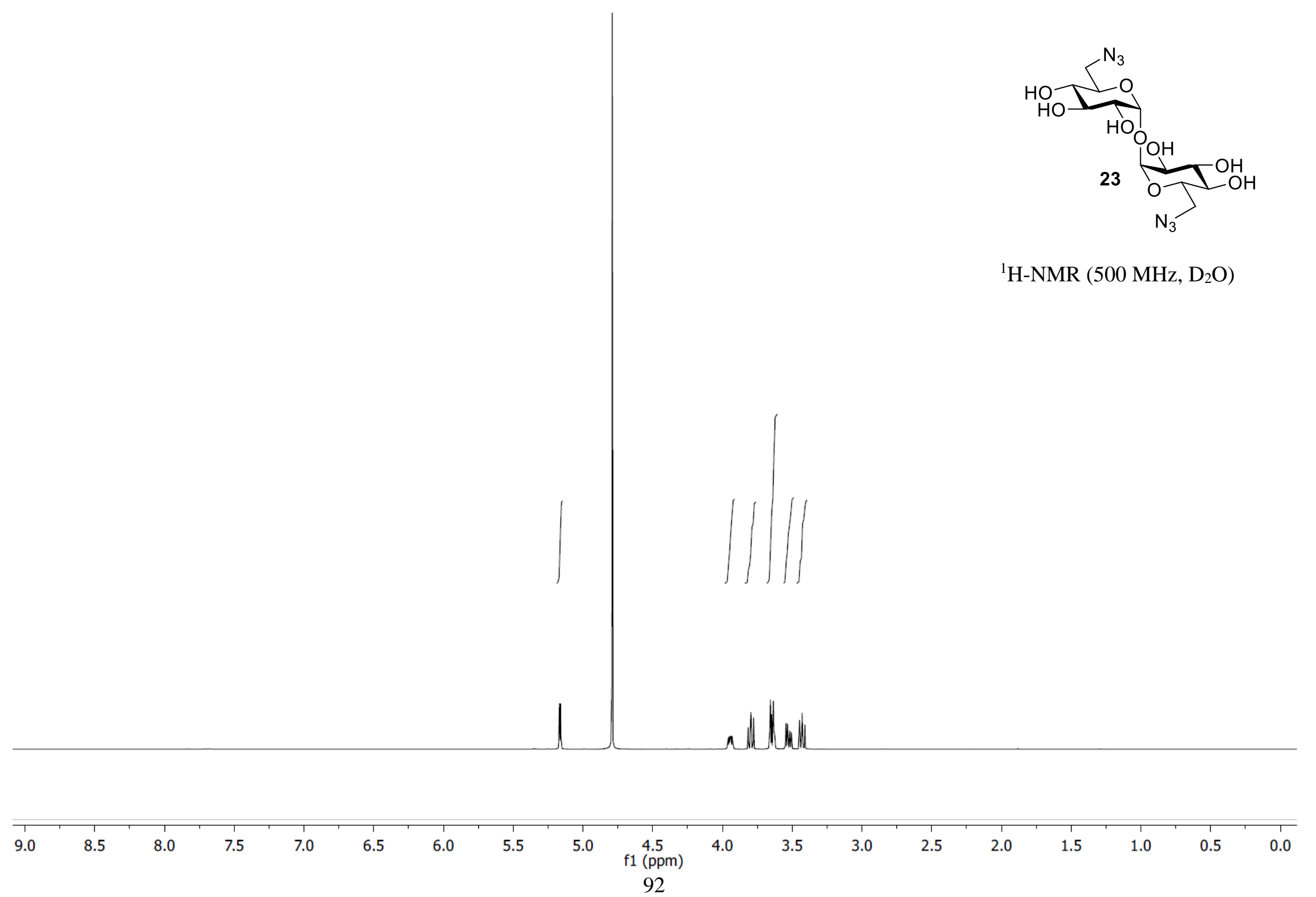




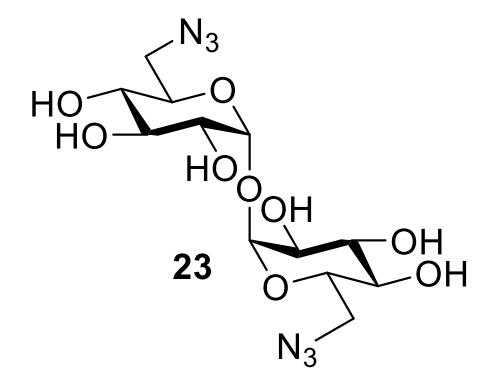

${ }^{13} \mathrm{C}-\mathrm{NMR}\left(125 \mathrm{MHz}, \mathrm{D}_{2} \mathrm{O}\right.$ )

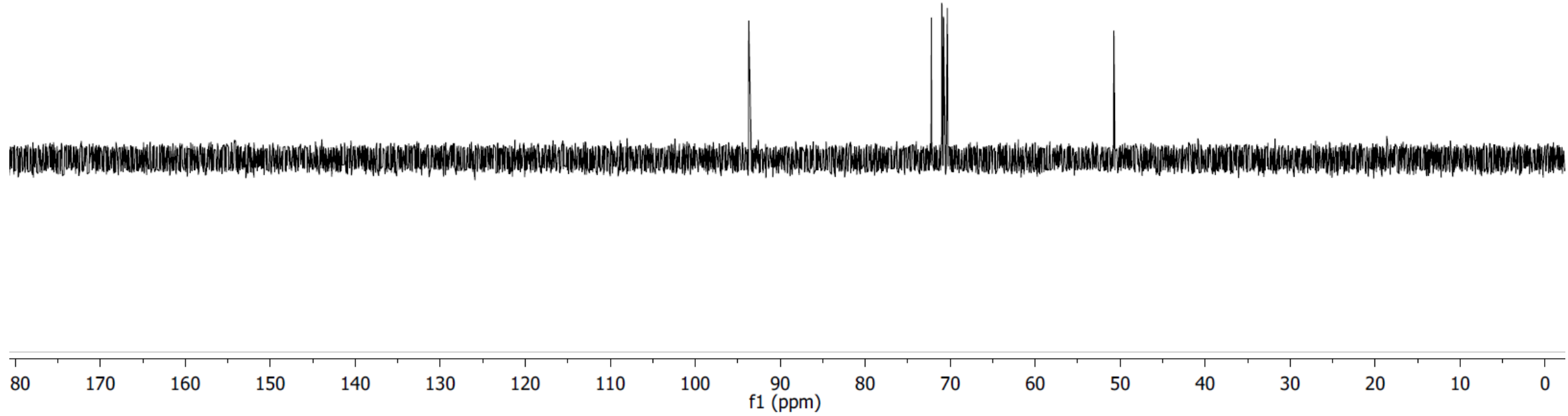




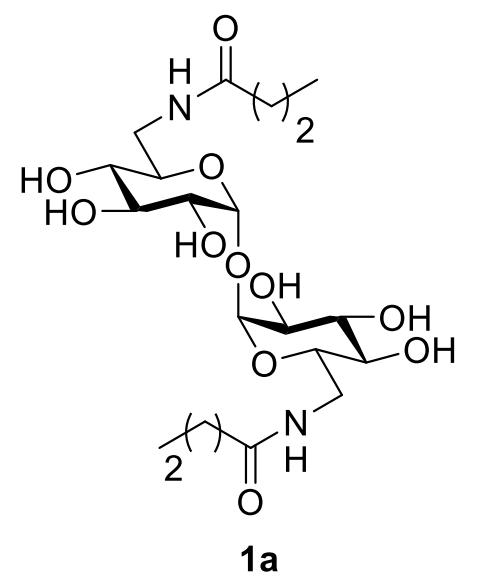

${ }^{1} \mathrm{H}-\mathrm{NMR}\left(500 \mathrm{MHz}, \mathrm{CD}_{3} \mathrm{OD}\right)$
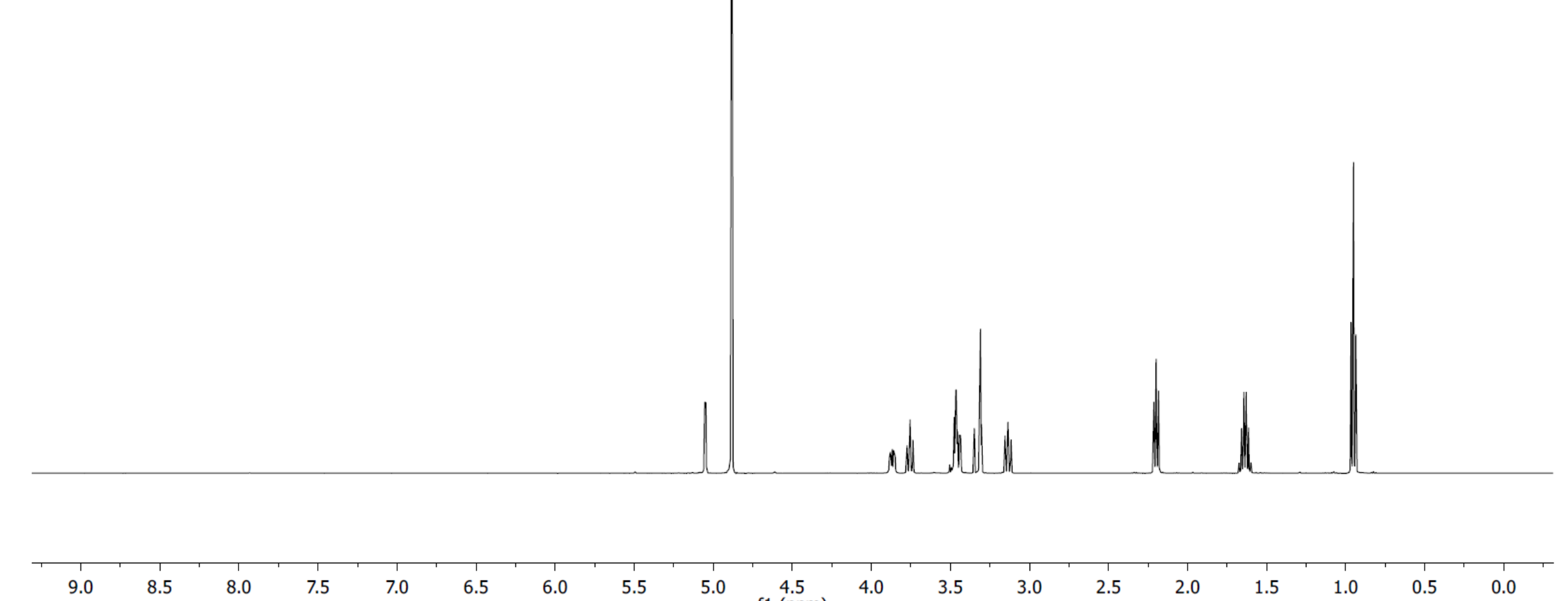

8.5
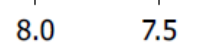

7.0
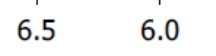

5.5

5.0

4.5
$(\mathrm{ppm})$
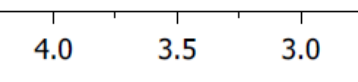

2.5

2.0

1.5 


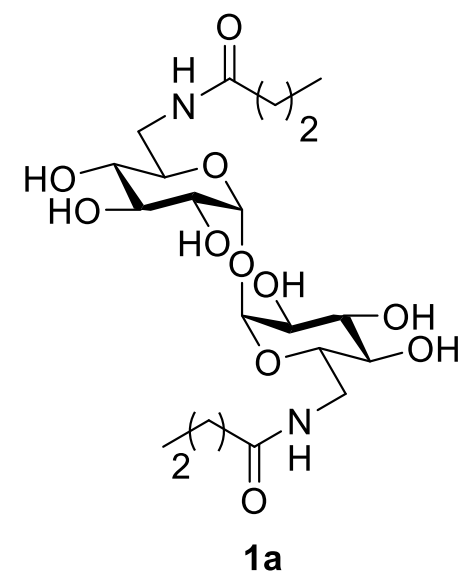

${ }^{13} \mathrm{C}-\mathrm{NMR}\left(125 \mathrm{MHz}, \mathrm{CD}_{3} \mathrm{OD}\right)$

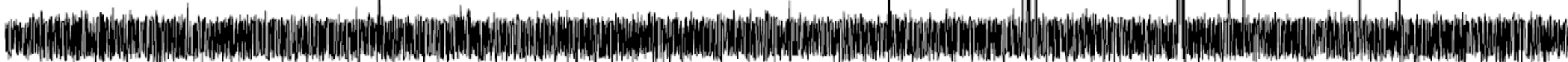

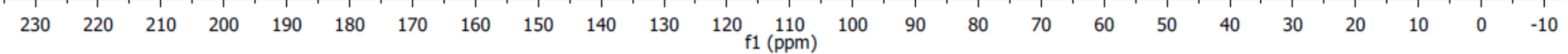




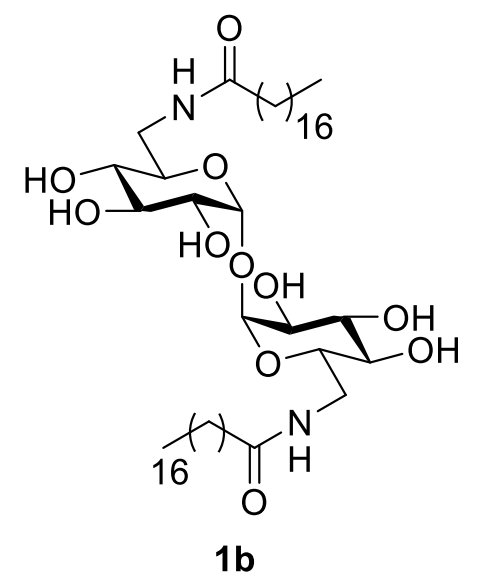

${ }^{1} \mathrm{H}-\mathrm{NMR}\left(500 \mathrm{MHz}, \mathrm{C}_{5} \mathrm{D}_{5} \mathrm{~N}\right.$ )

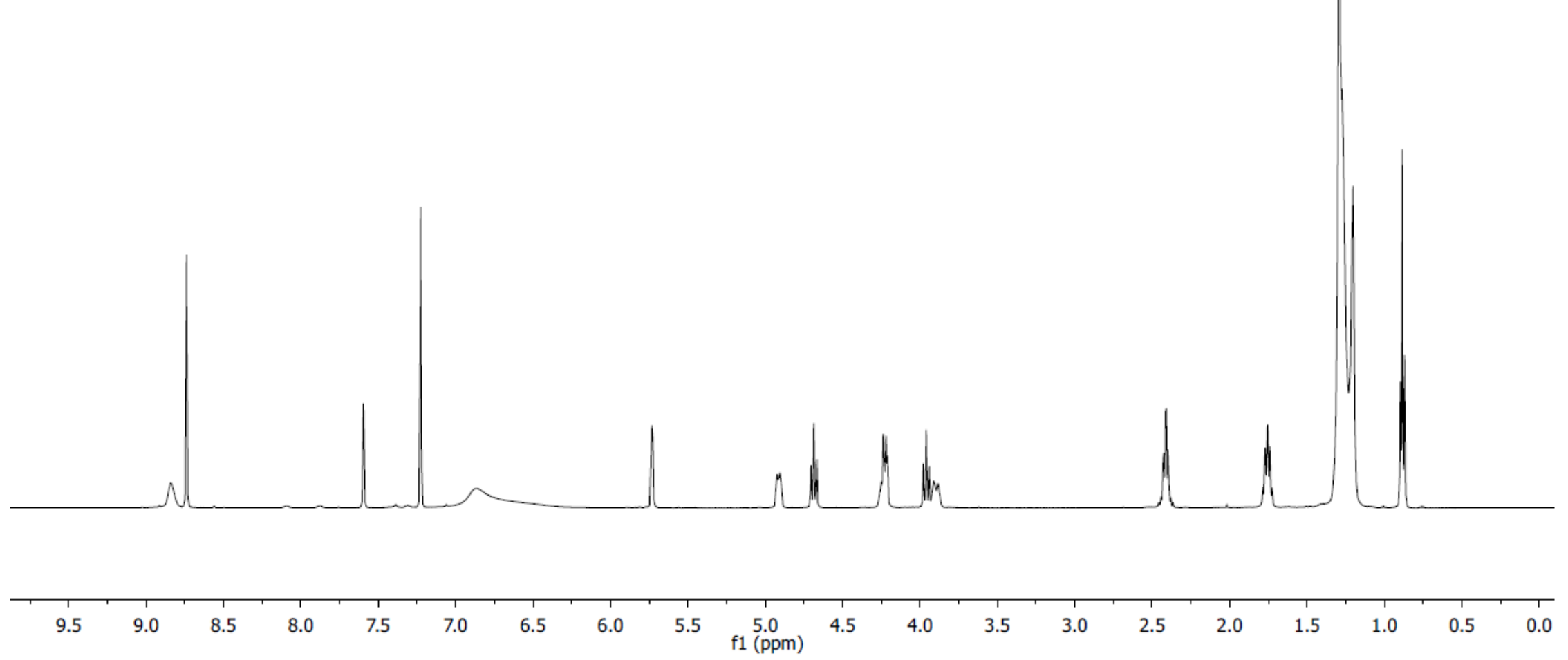




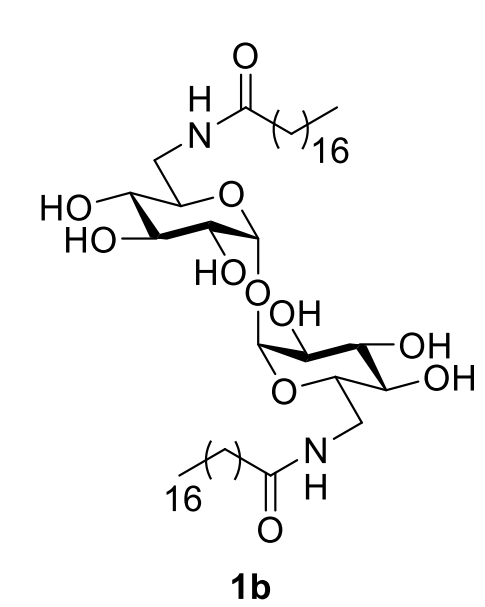

${ }^{13} \mathrm{C}-\mathrm{NMR}\left(125 \mathrm{MHz}, \mathrm{C}_{5} \mathrm{D}_{5} \mathrm{~N}\right)$

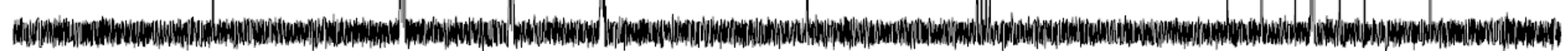

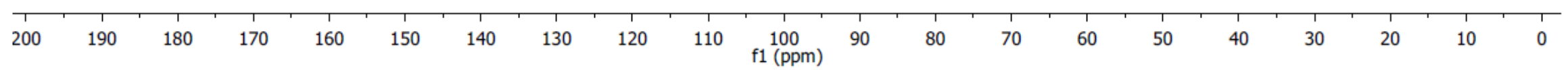

97 

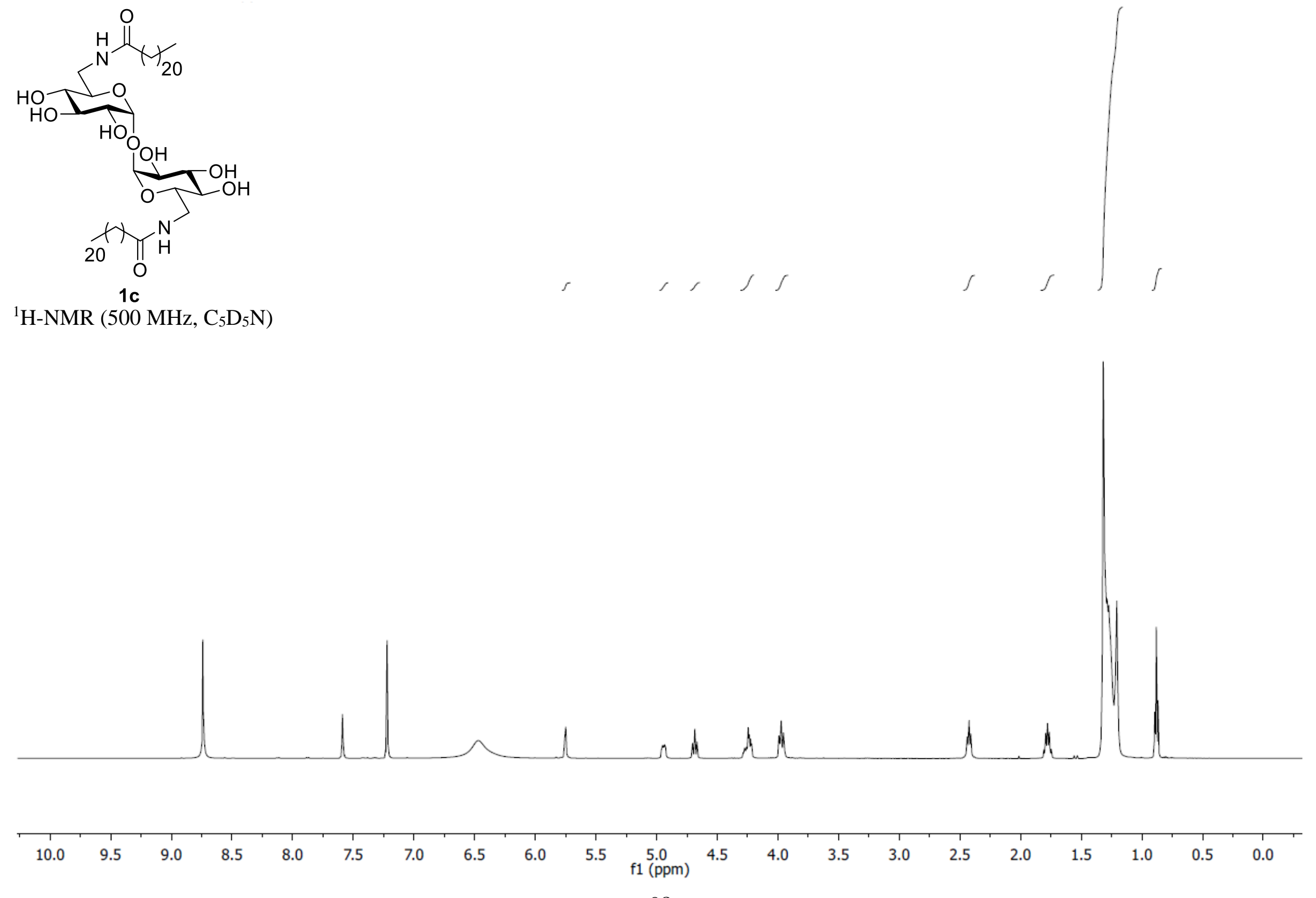

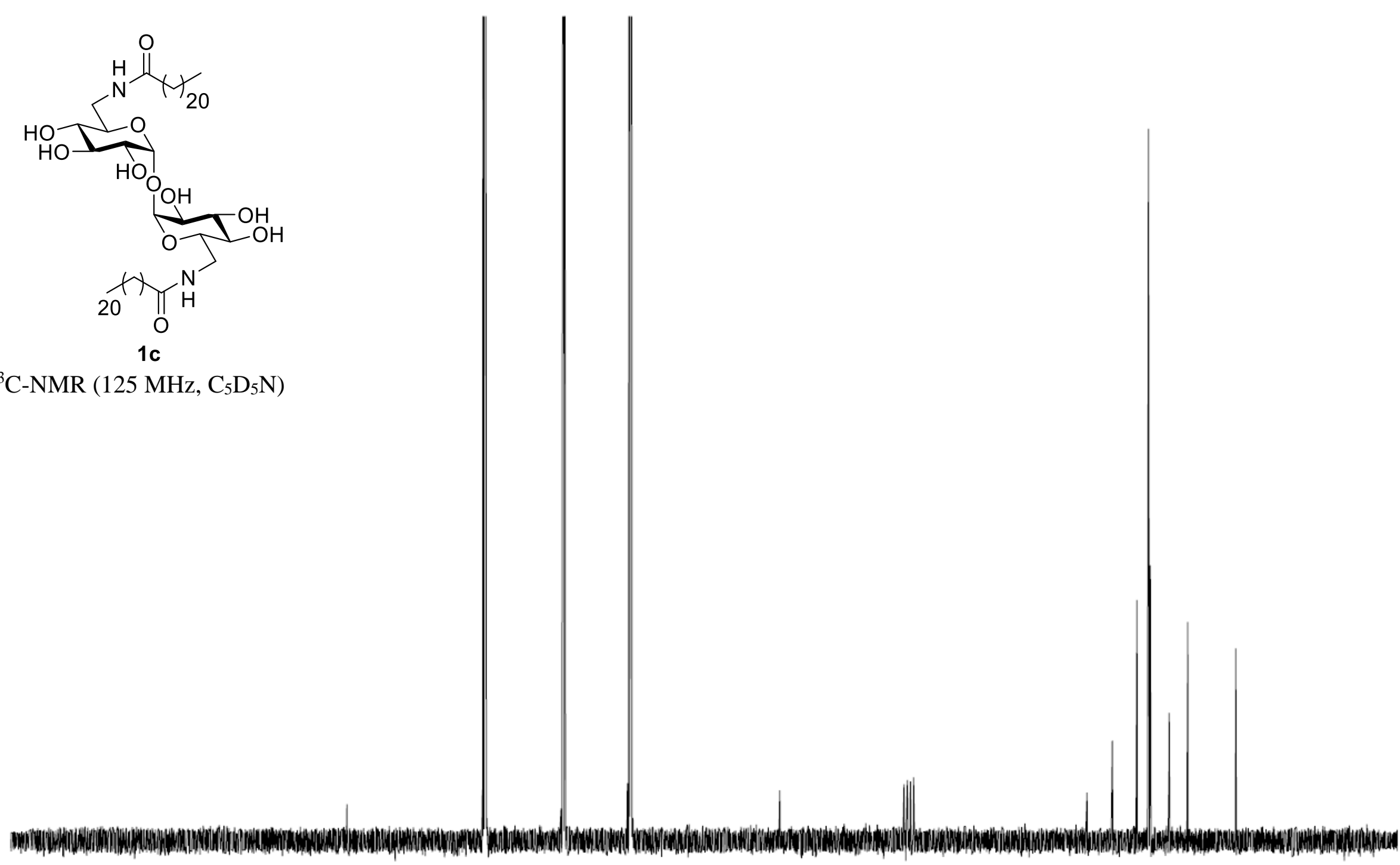

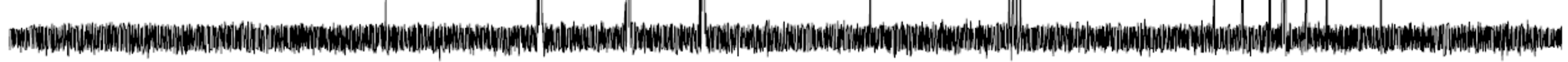

${ }^{13} \mathrm{C}-\mathrm{NMR}\left(125 \mathrm{MHz}, \mathrm{C}_{5} \mathrm{D}_{5} \mathrm{~N}\right)$

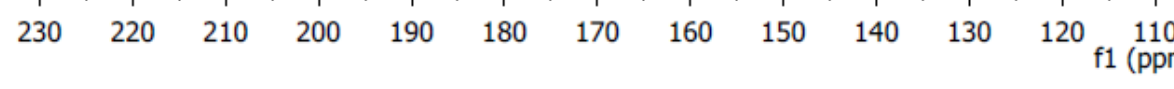




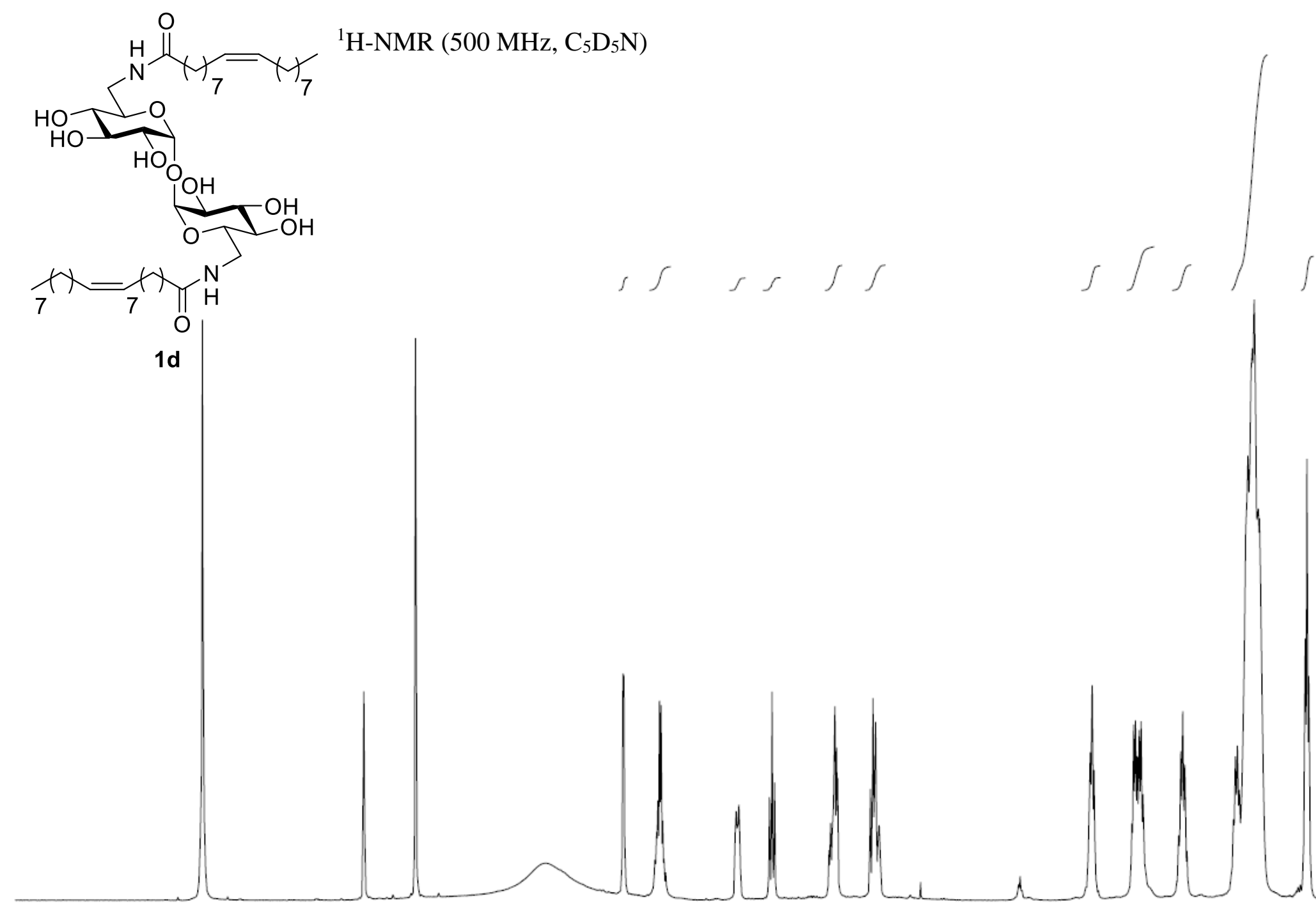

$\begin{array}{ll}1 \\ .0 .0 & 9.5\end{array}$

$\begin{array}{lll}9.0 & 8.5 & 8.0\end{array}$

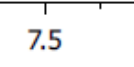

$\begin{array}{ll}7.0 & 6.5\end{array}$

6.0

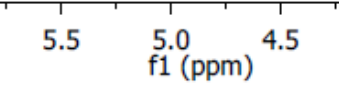




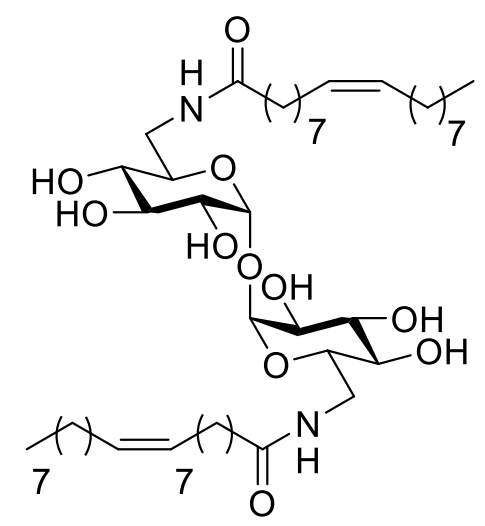

${ }^{13} \mathrm{C}-\mathrm{NMR}\left(125^{1 \mathbf{d}} \mathrm{MHz}, \mathrm{C}_{5} \mathrm{D}_{5} \mathrm{~N}\right)$
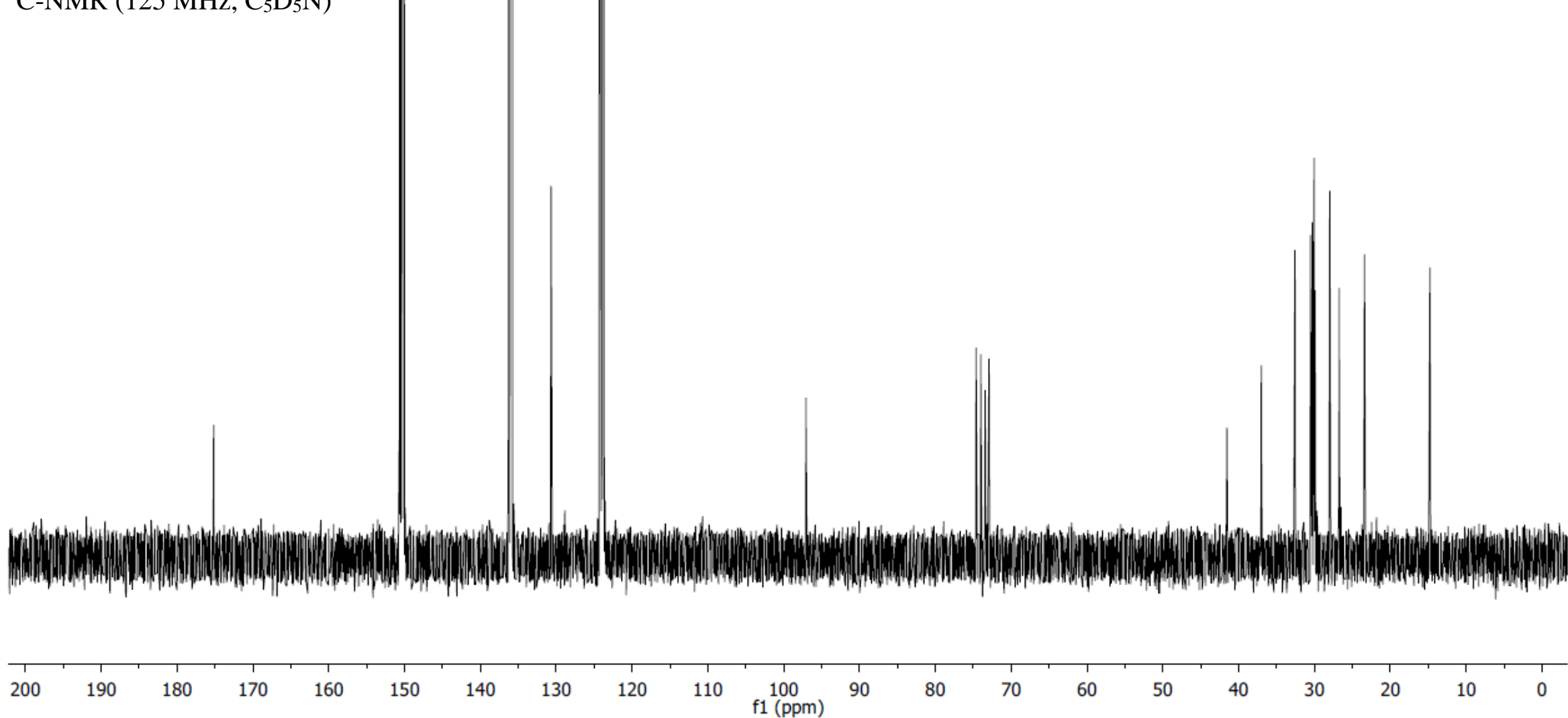


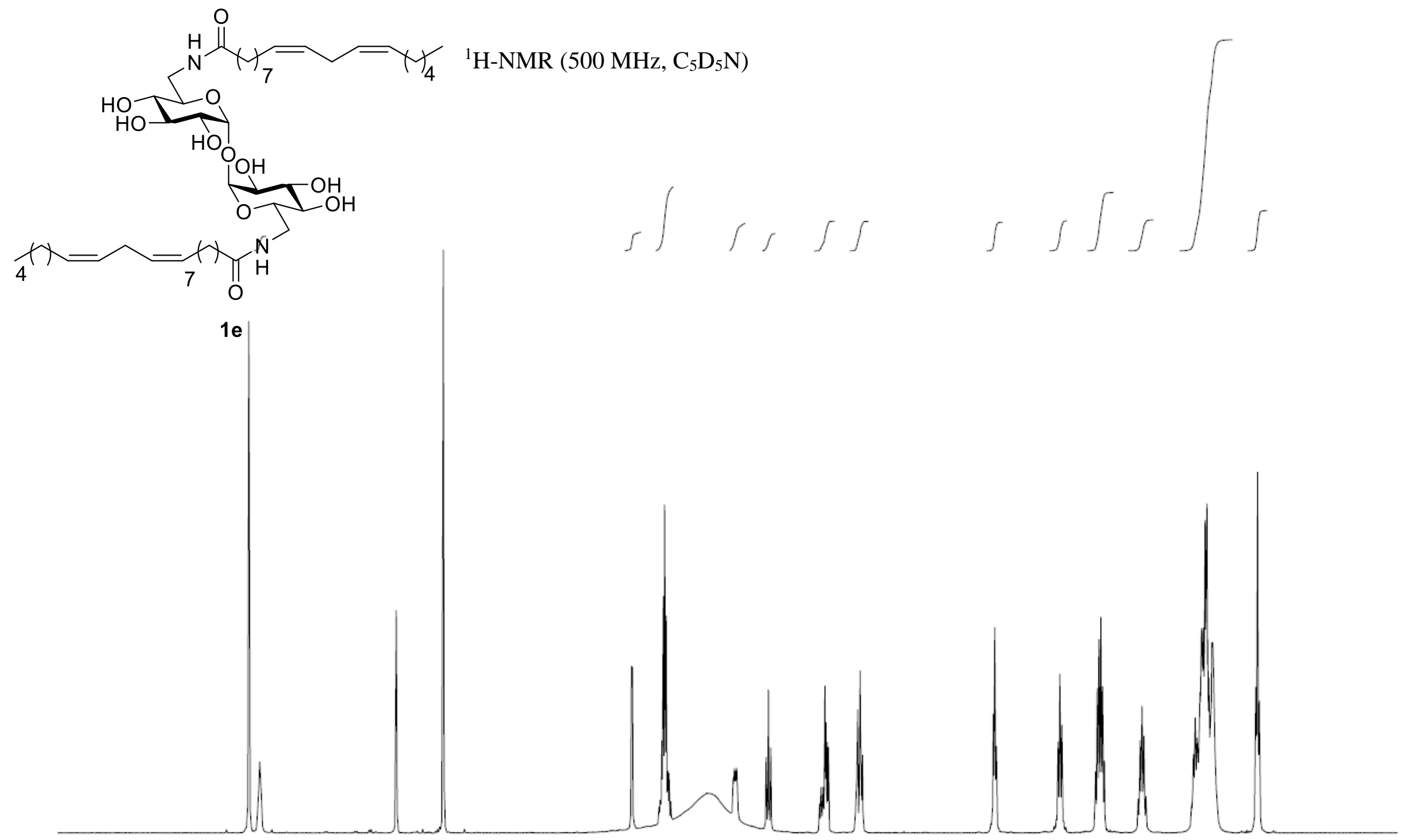




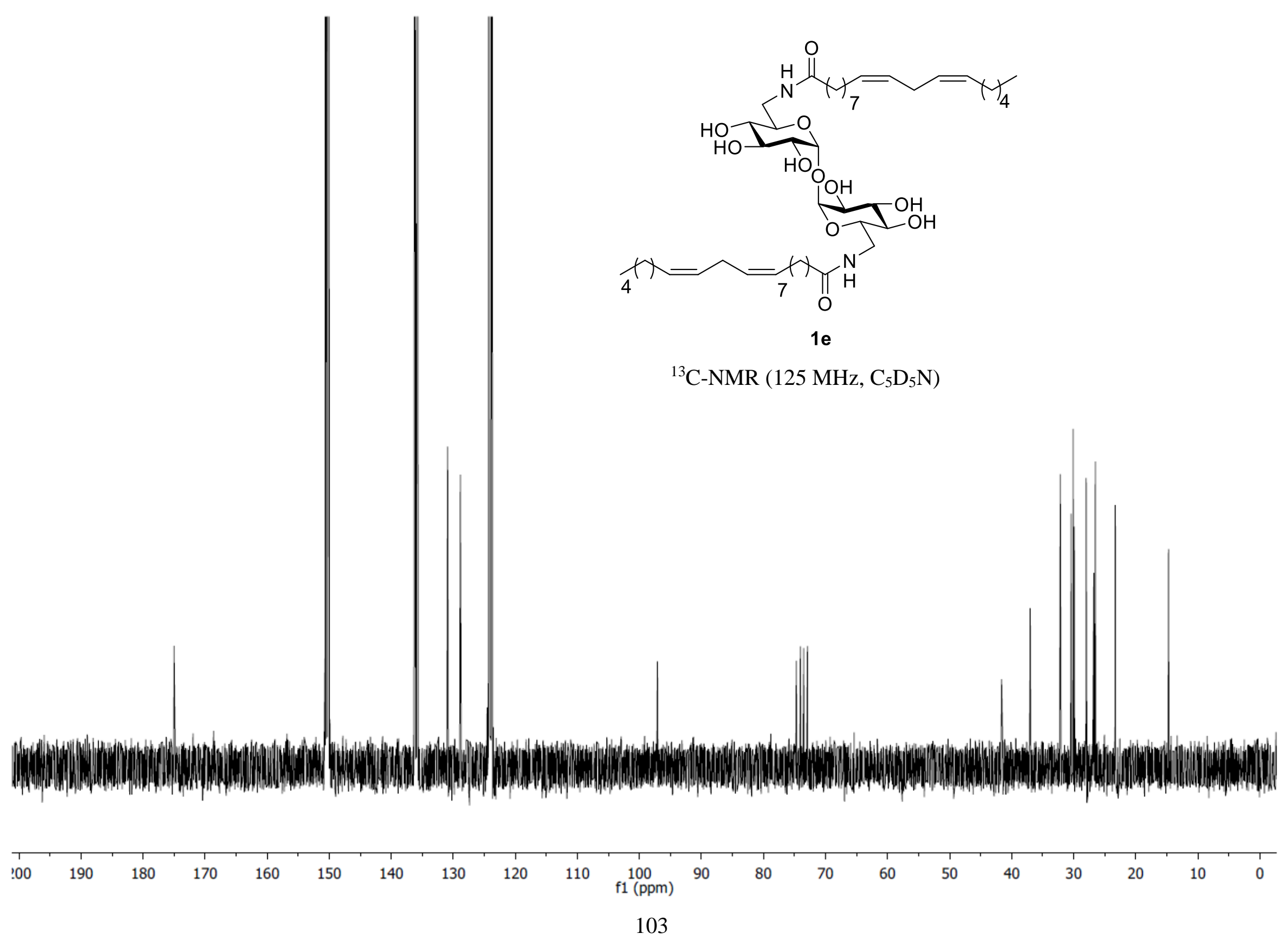




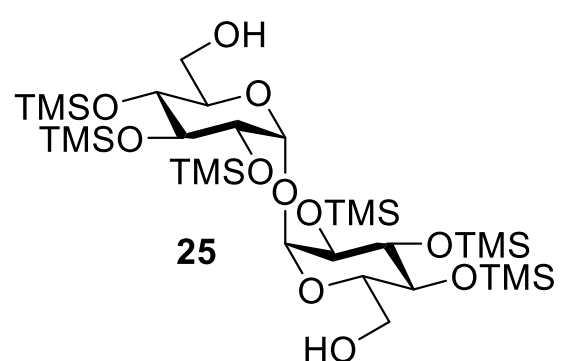

${ }^{1} \mathrm{H}-\mathrm{NMR}\left(500 \mathrm{MHz}, \mathrm{CDCl}_{3}\right.$ )
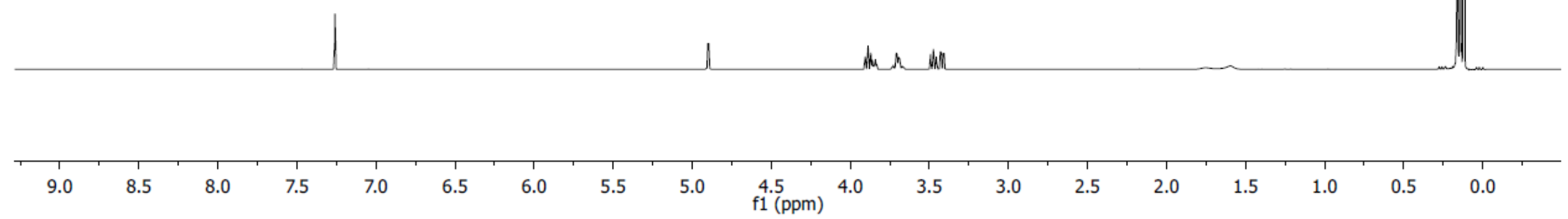


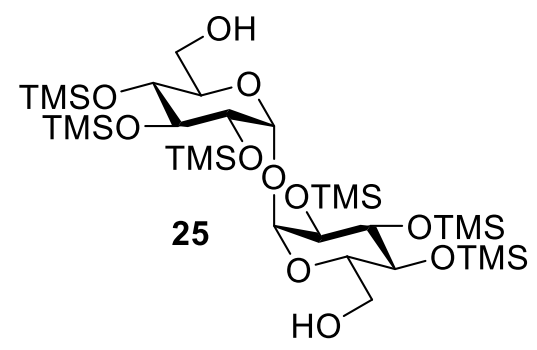

${ }^{13} \mathrm{C}-\mathrm{NMR}\left(125 \mathrm{MHz}, \mathrm{CDCl}_{3}\right)$

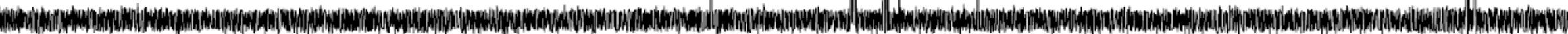

\begin{tabular}{|c|c|c|c|c|c|c|c|c|c|c|c|c|c|c|c|c|c|c|}
\hline 180 & 170 & 160 & 150 & 140 & 130 & 120 & 110 & 100 & 80 & 70 & 60 & 50 & 40 & 30 & 20 & 10 & 0 & -10 \\
\hline
\end{tabular}



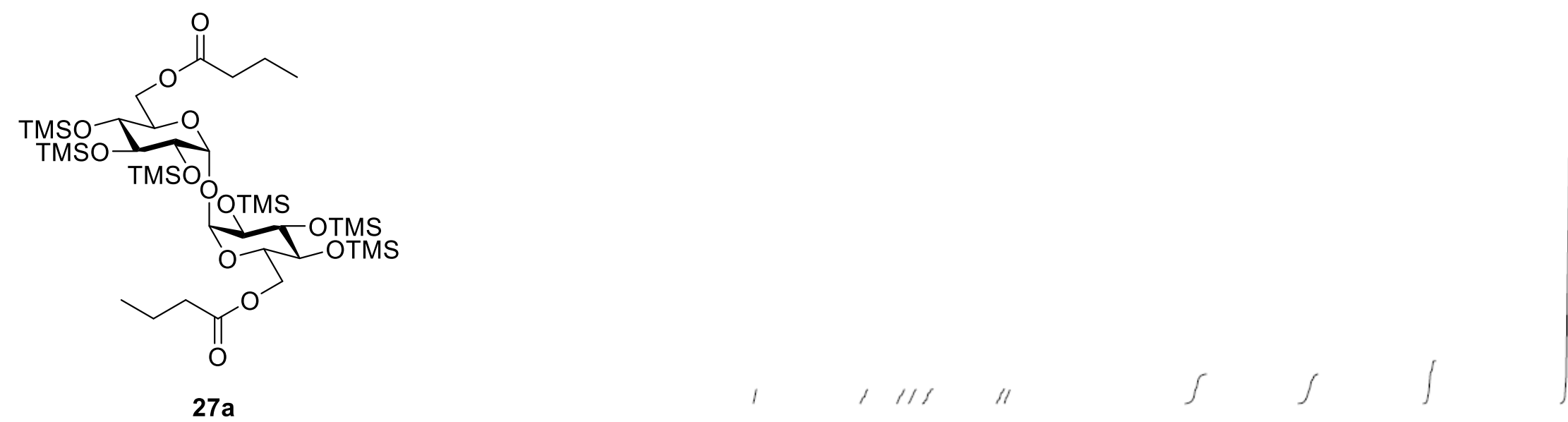

${ }^{1} \mathrm{H}-\mathrm{NMR}\left(500 \mathrm{MHz}, \mathrm{CDCl}_{3}\right)$

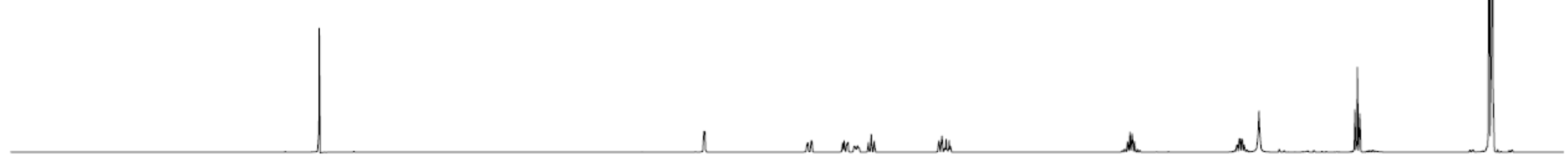

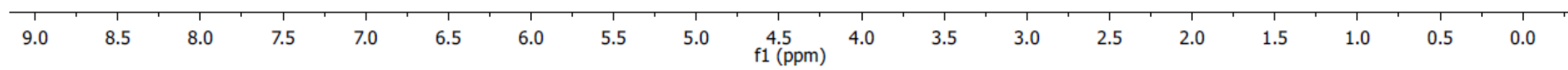




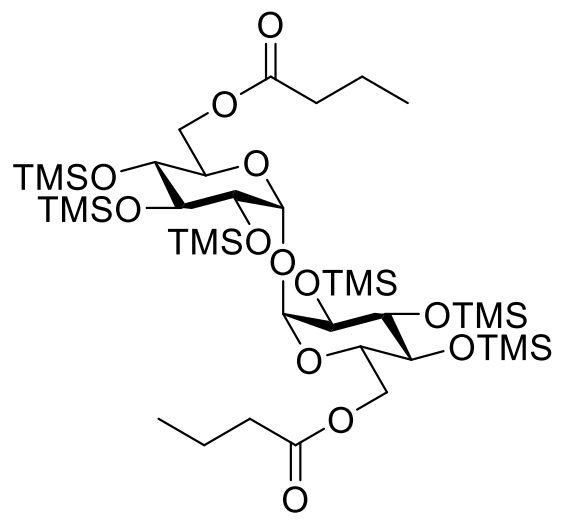

$27 a$

${ }^{13} \mathrm{C}-\mathrm{NMR}\left(125 \mathrm{MHz}, \mathrm{CDCl}_{3}\right)$
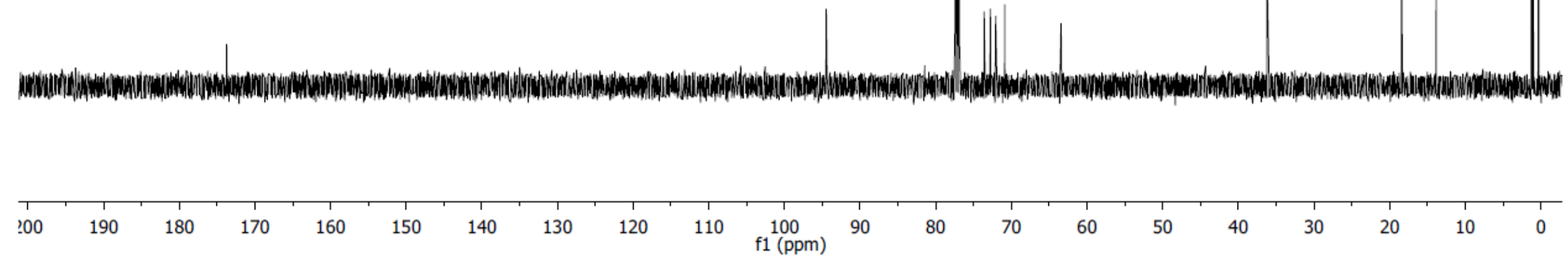


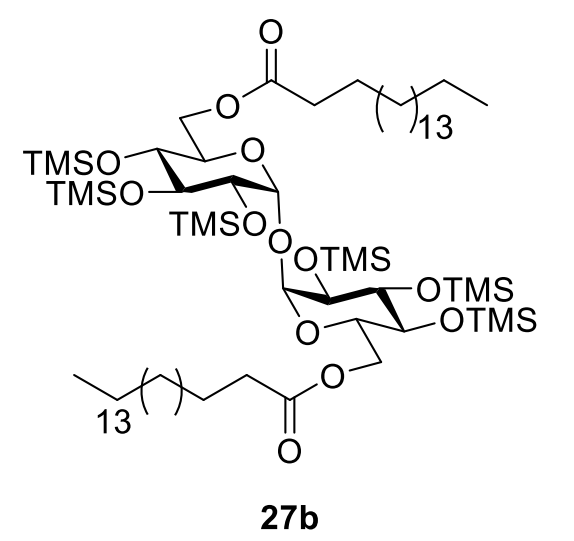

${ }^{1} \mathrm{H}-\mathrm{NMR}\left(500 \mathrm{MHz}, \mathrm{CDCl}_{3}\right)$

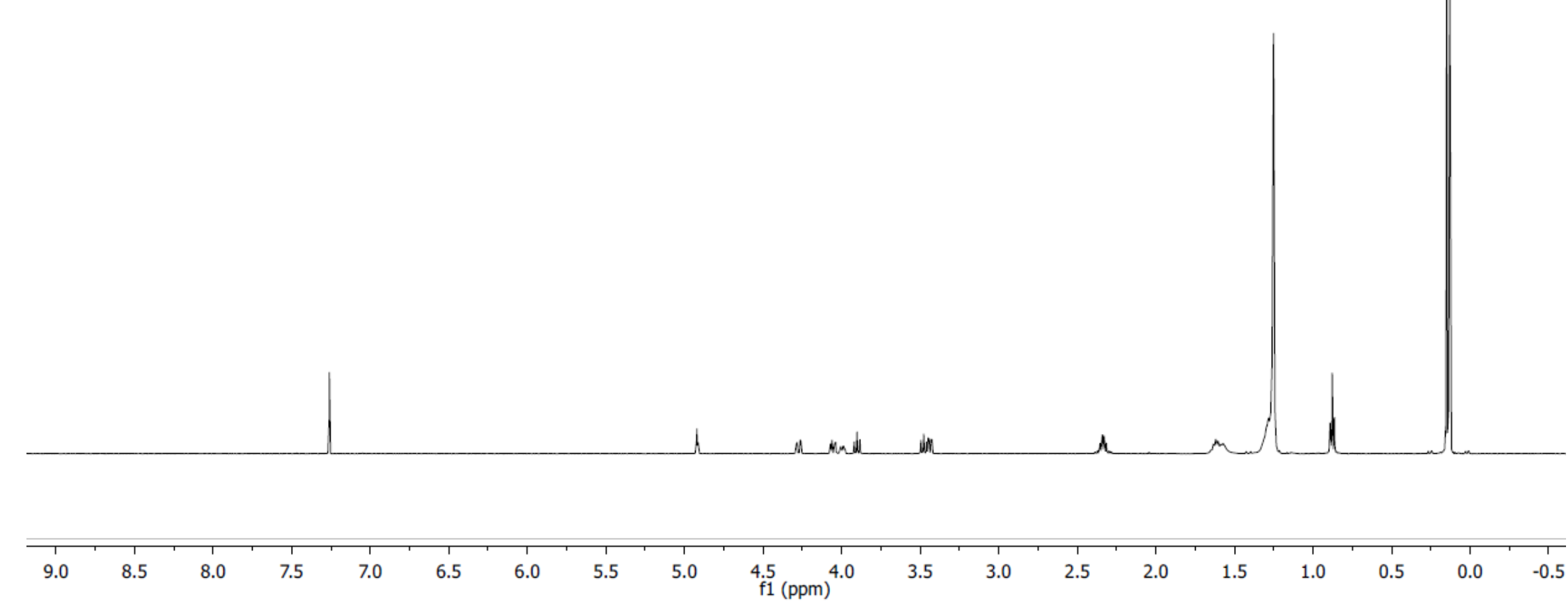




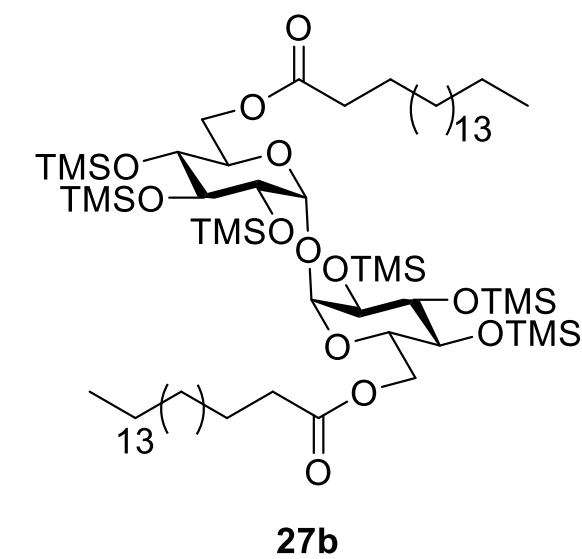

${ }^{13} \mathrm{C}-\mathrm{NMR}\left(125 \mathrm{MHz}, \mathrm{CDCl}_{3}\right)$

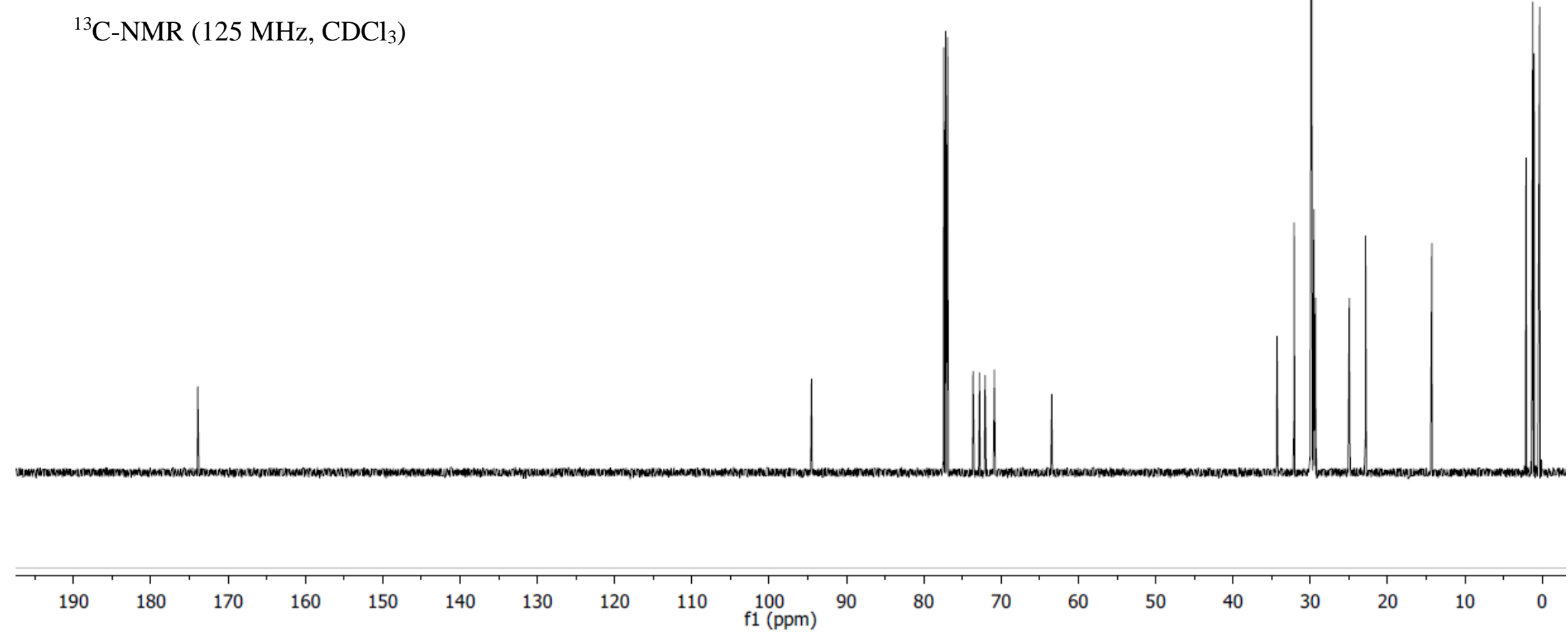




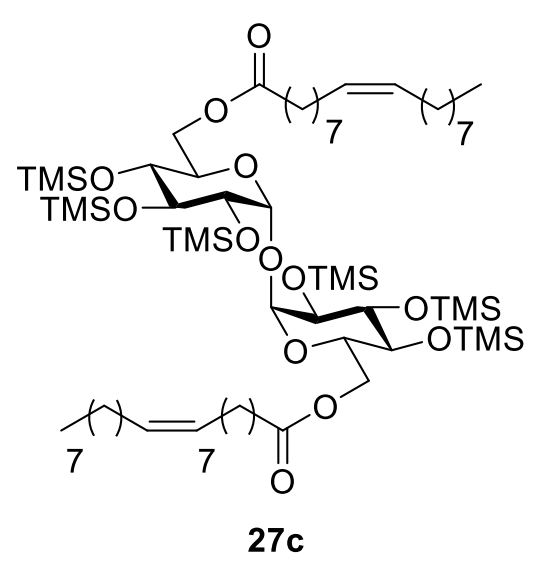

${ }^{1} \mathrm{H}-\mathrm{NMR}\left(500 \mathrm{MHz}, \mathrm{CDCl}_{3}\right.$ )
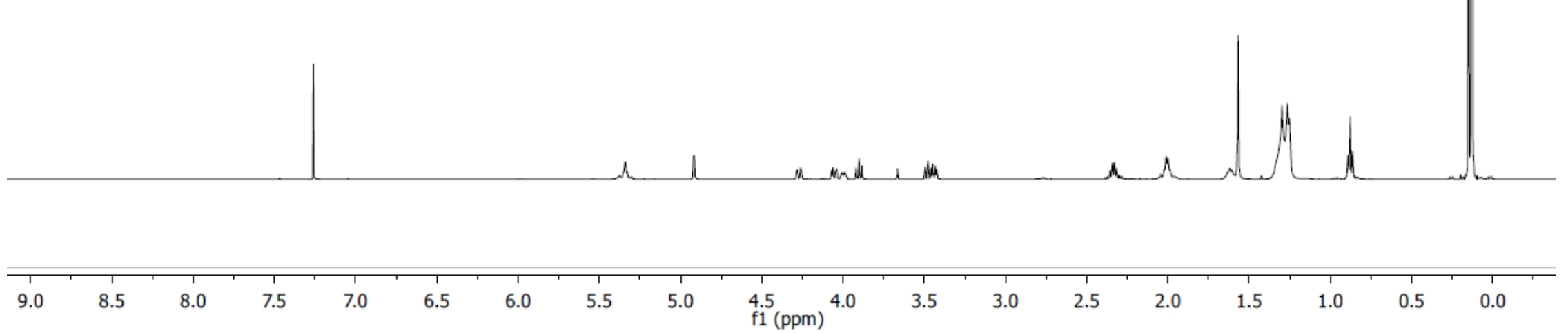


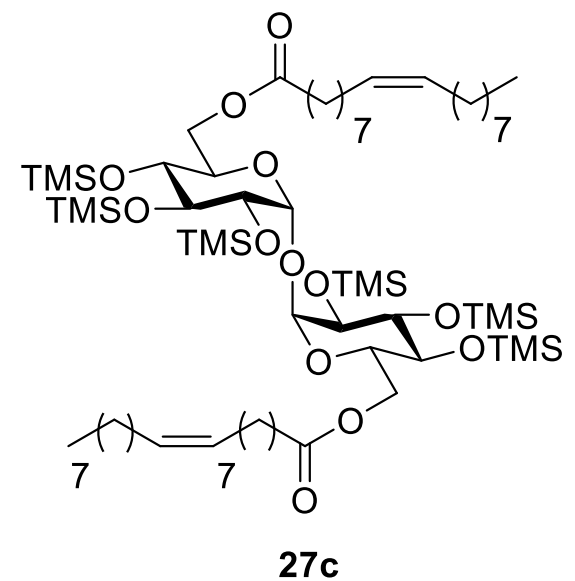

${ }^{13} \mathrm{C}-\mathrm{NMR}\left(125 \mathrm{MHz}, \mathrm{CDCl}_{3}\right)$
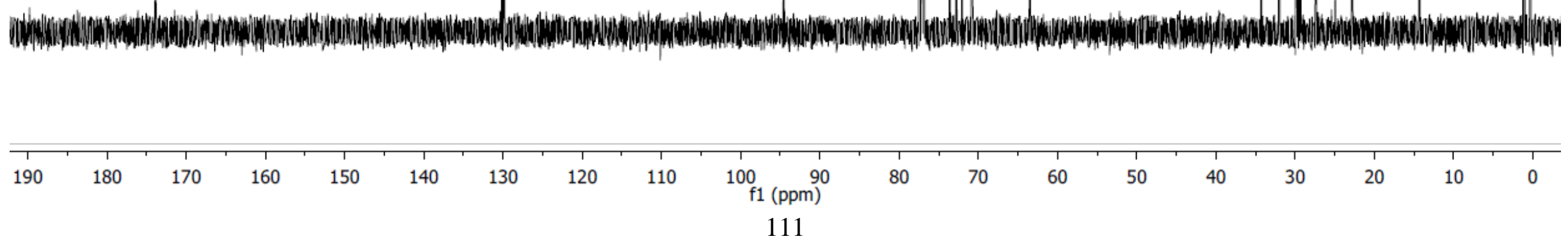


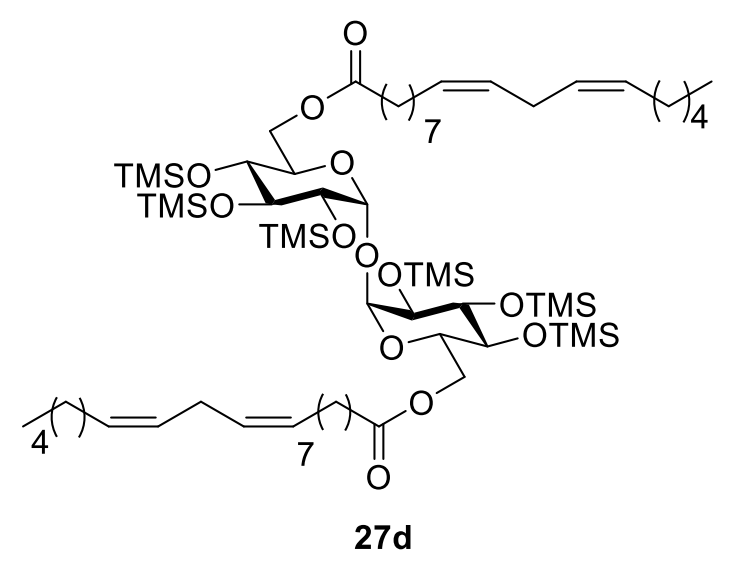

${ }^{1} \mathrm{H}-\mathrm{NMR}\left(500 \mathrm{MHz}, \mathrm{CDCl}_{3}\right.$ )
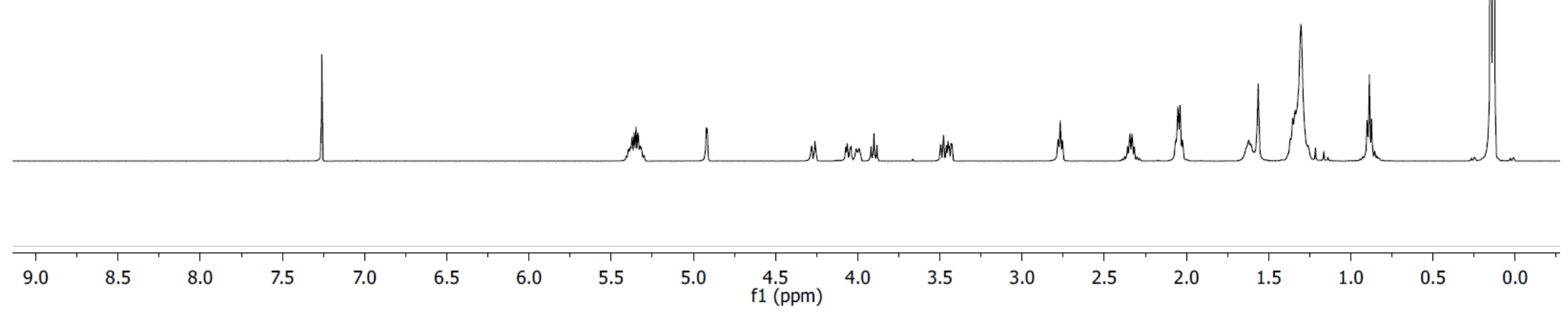


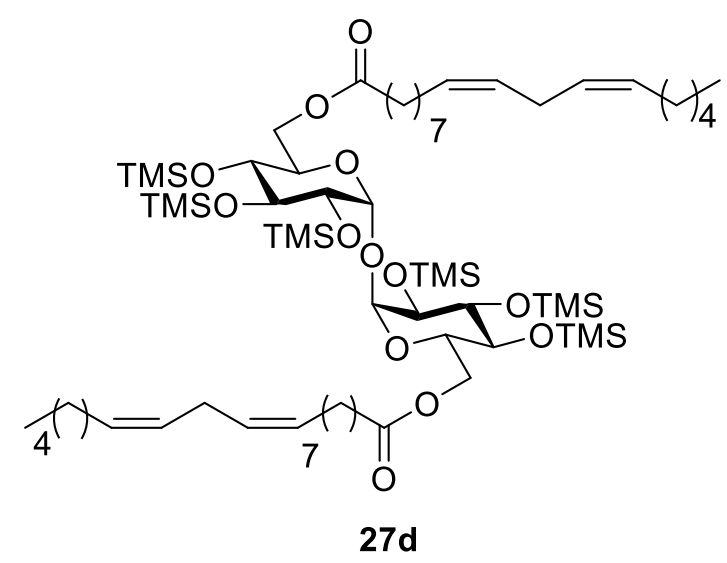

${ }^{13} \mathrm{C}-\mathrm{NMR}\left(125 \mathrm{MHz}, \mathrm{CDCl}_{3}\right)$

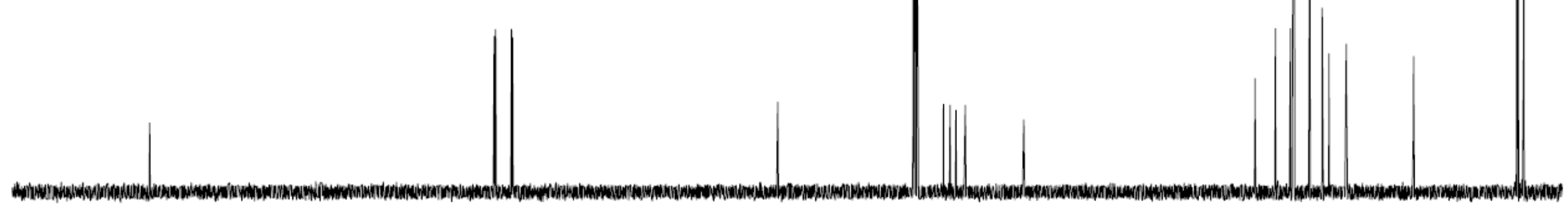

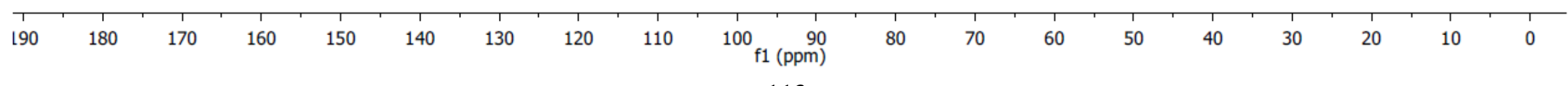




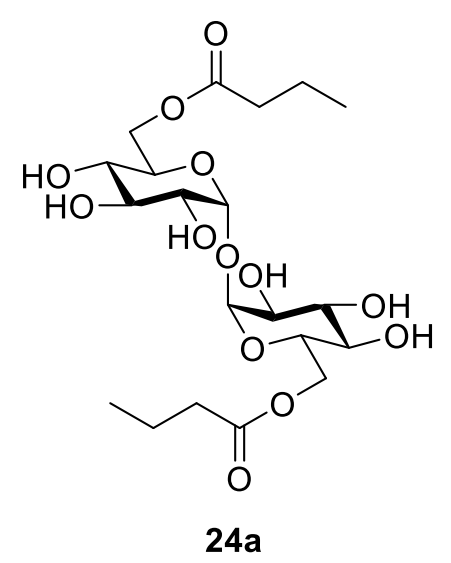

${ }^{1} \mathrm{H}-\mathrm{NMR}\left(500 \mathrm{MHz}, \mathrm{CD}_{3} \mathrm{OD}\right)$

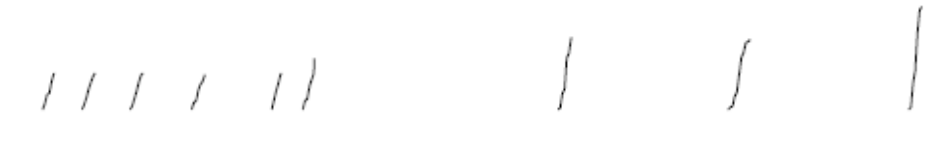

HNMR (500 MHz, CDsOD)
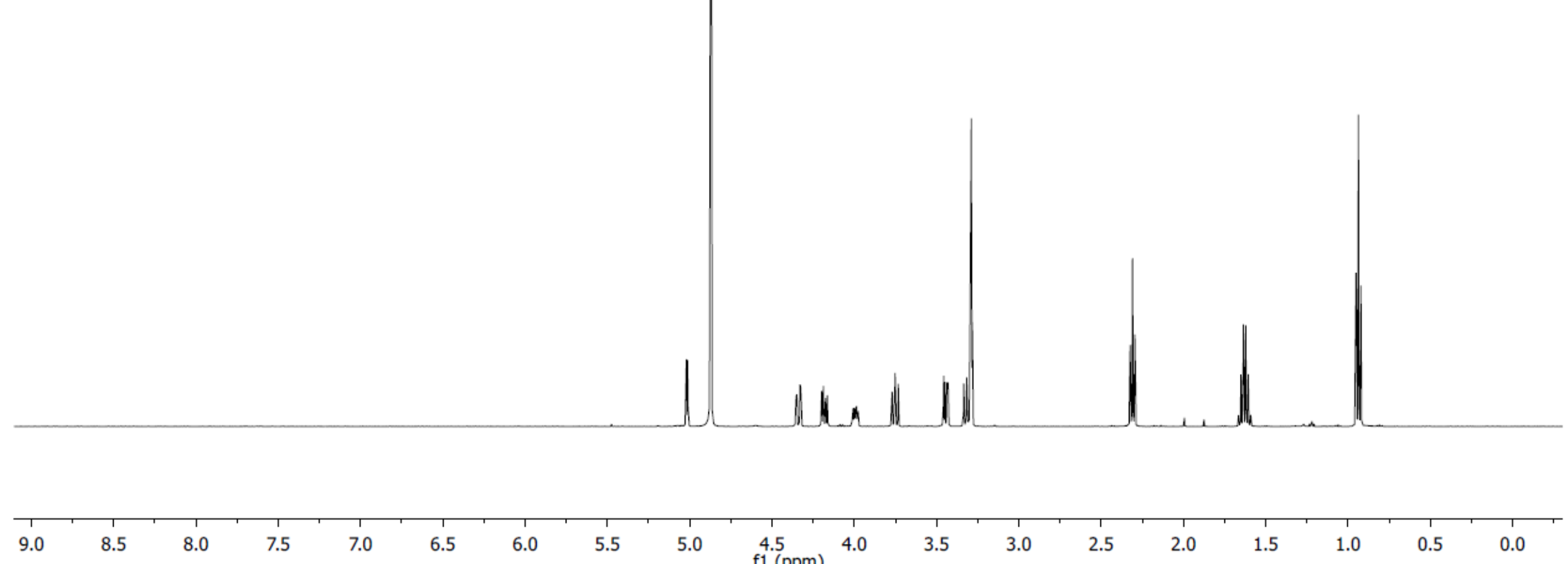


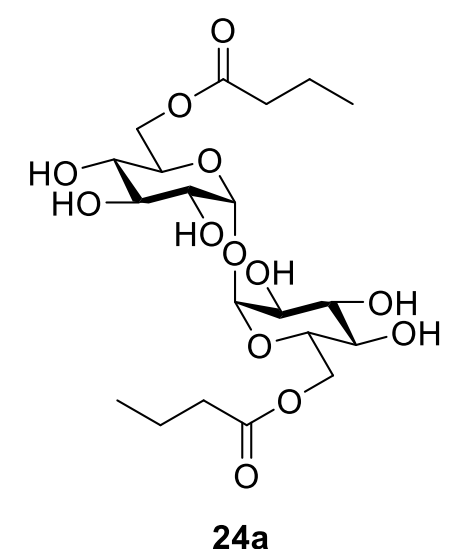

${ }^{13} \mathrm{C}-\mathrm{NMR}$ (125 MHz, $\left.\mathrm{CD}_{3} \mathrm{OD}\right)$
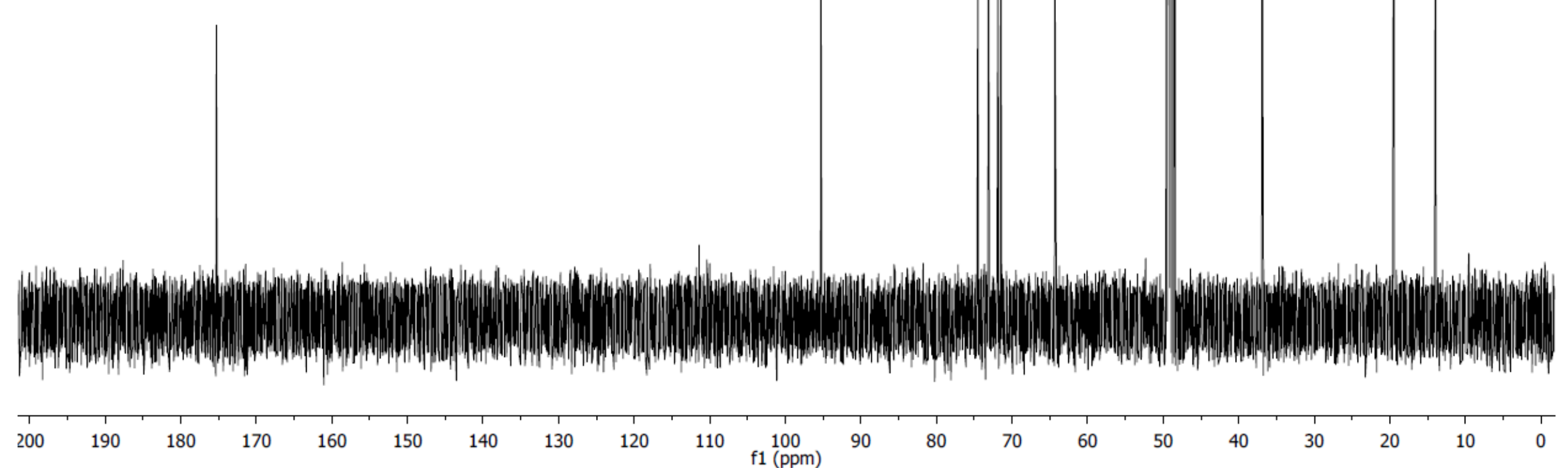


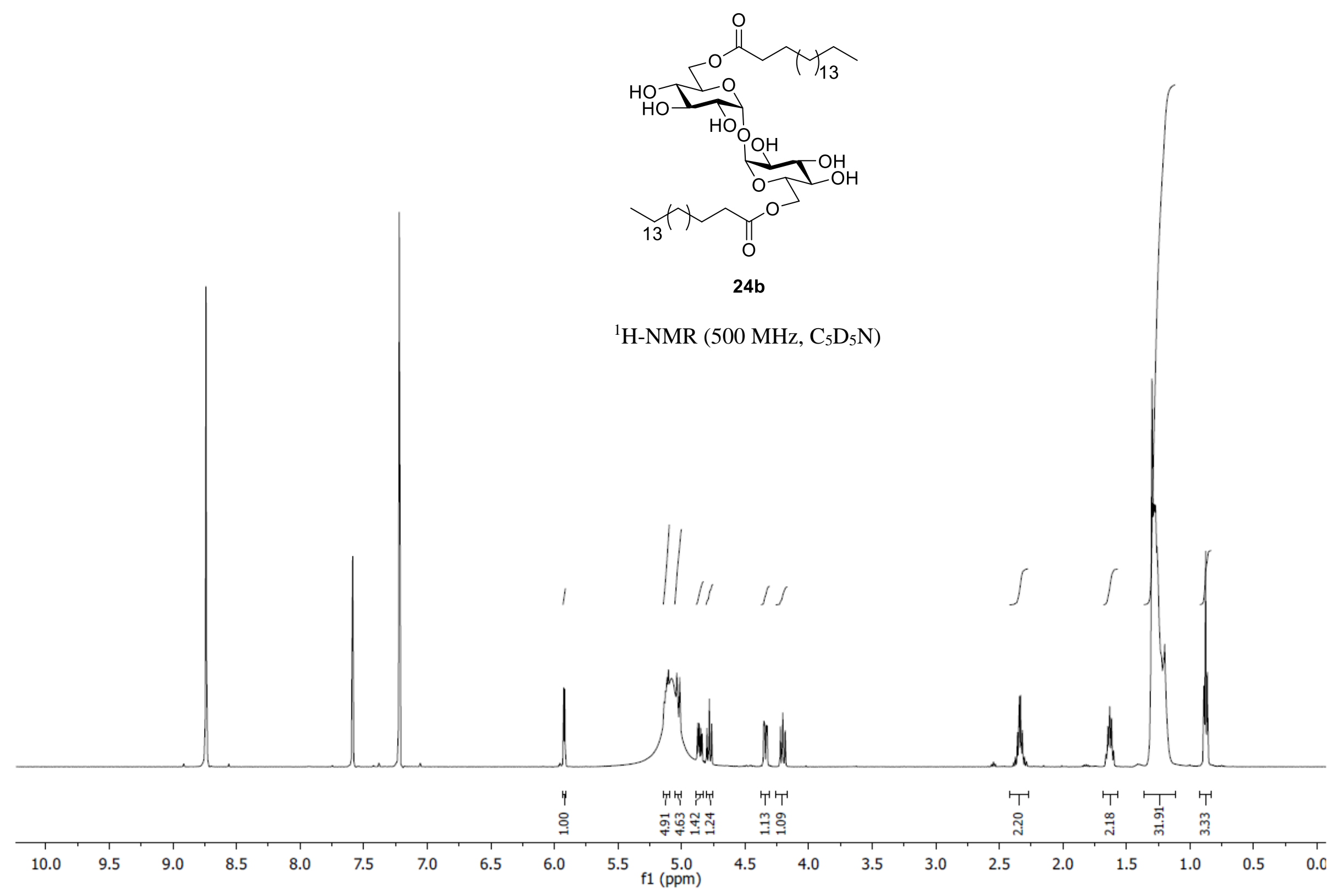



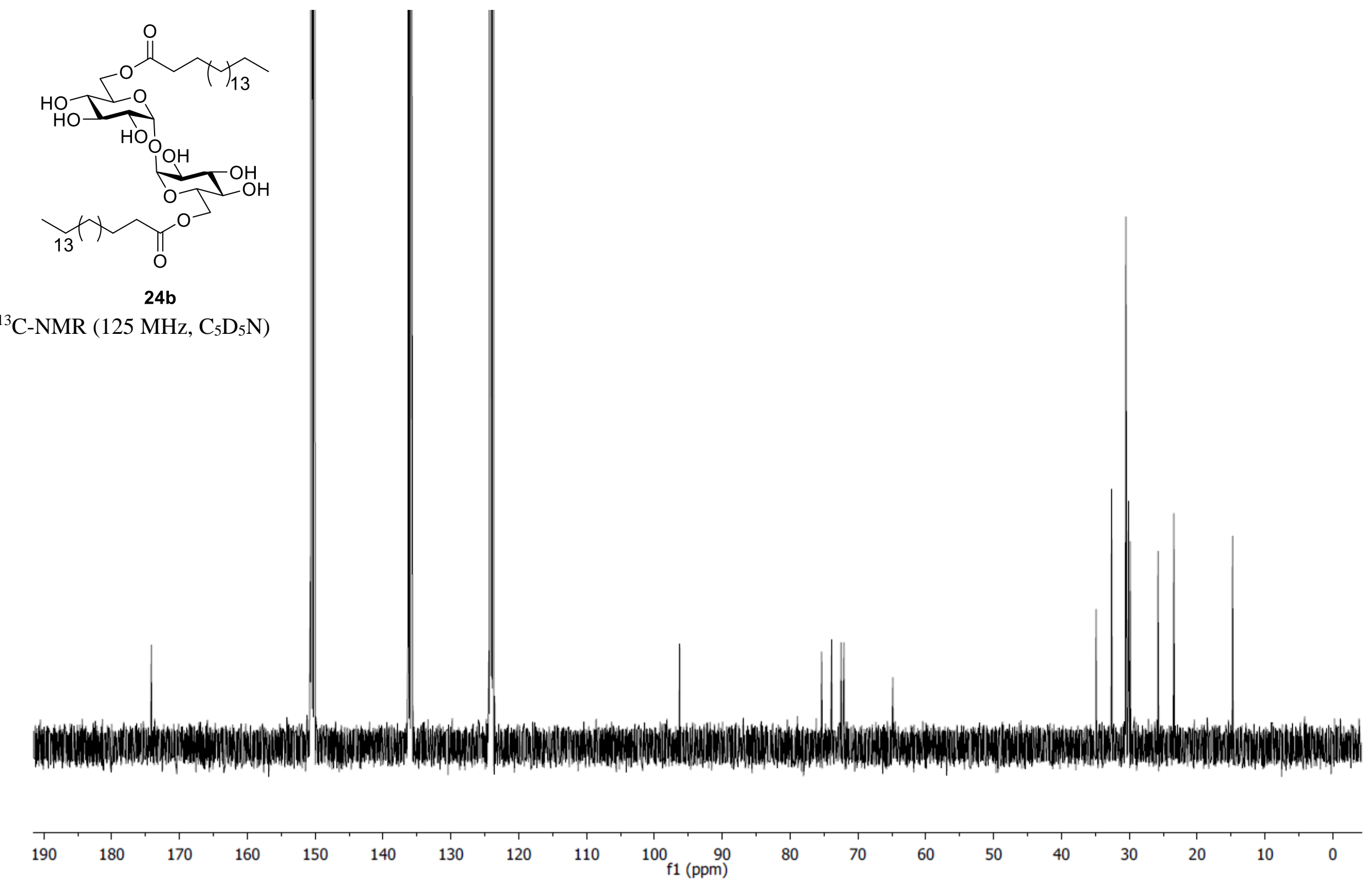


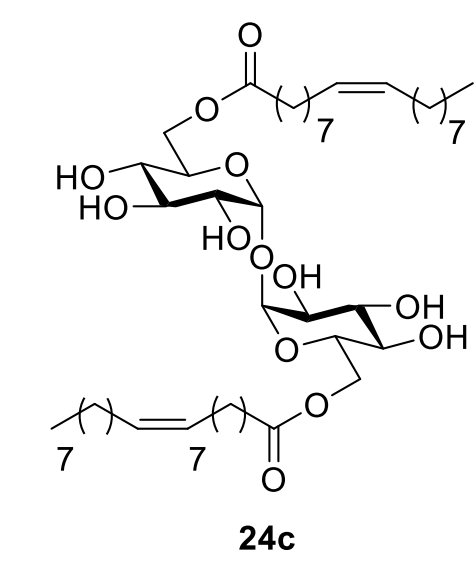

${ }^{1} \mathrm{H}-\mathrm{NMR}\left(500 \mathrm{MHz}, \mathrm{C}_{5} \mathrm{D}_{5} \mathrm{~N}\right)$

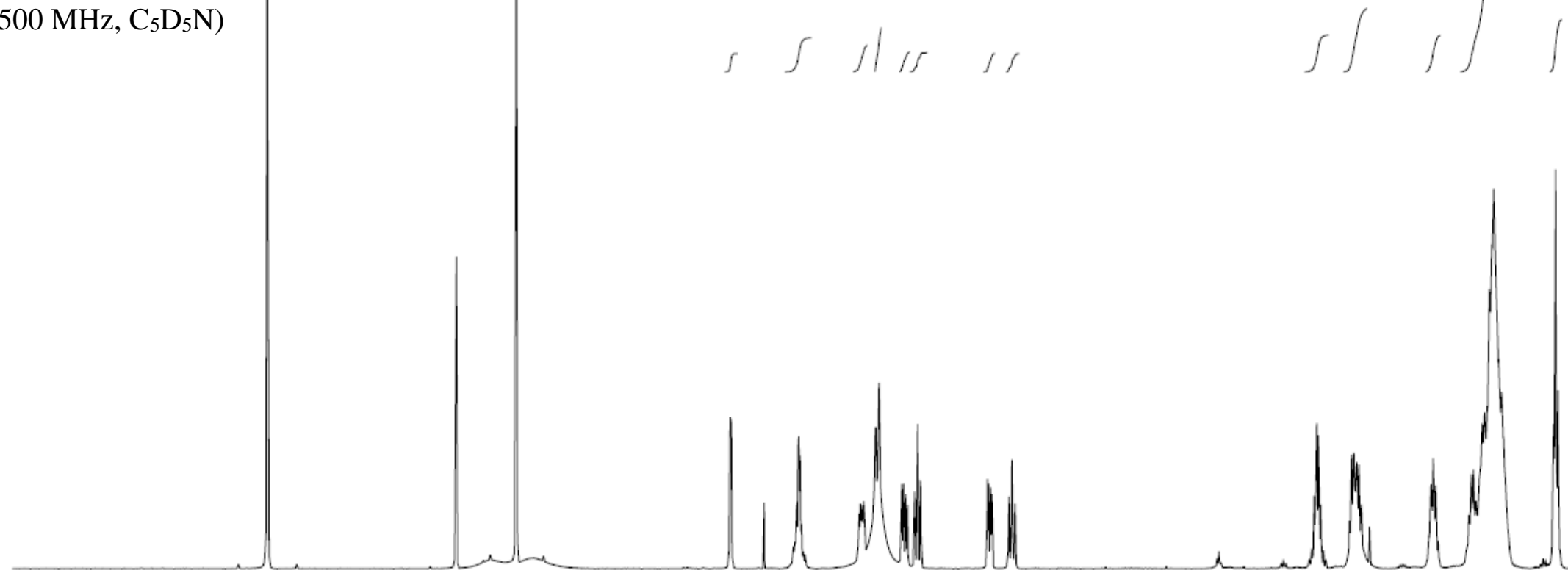




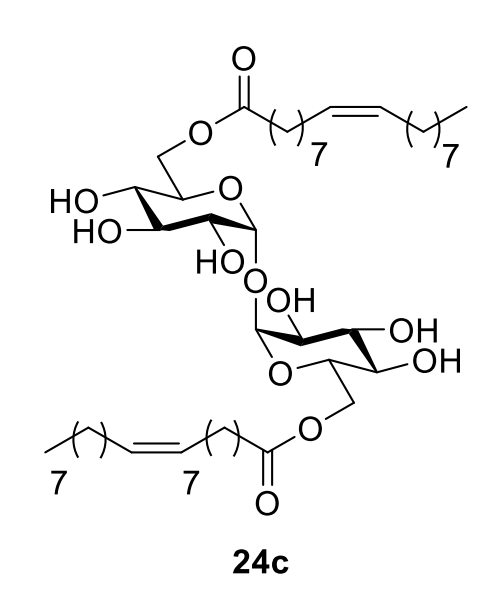

${ }^{13} \mathrm{C}-\mathrm{NMR}\left(125 \mathrm{MHz}, \mathrm{C}_{5} \mathrm{D}_{5} \mathrm{~N}\right)$
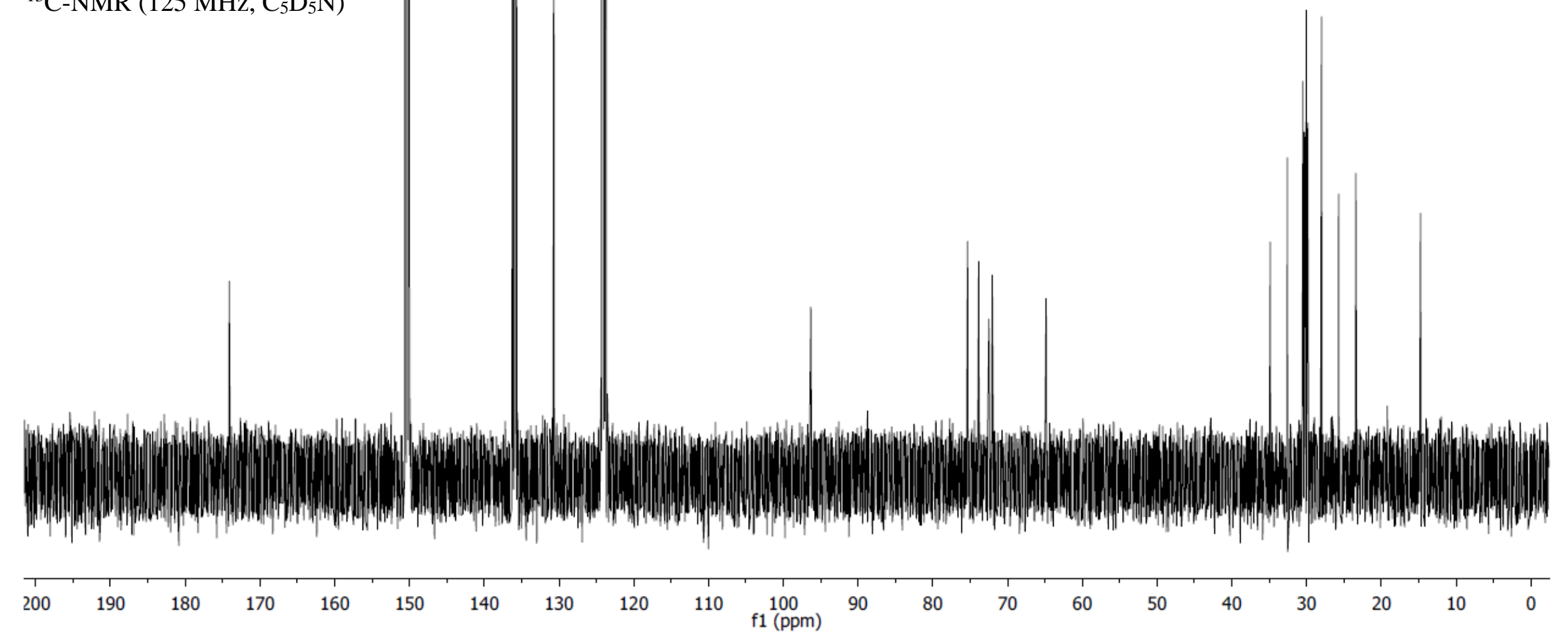

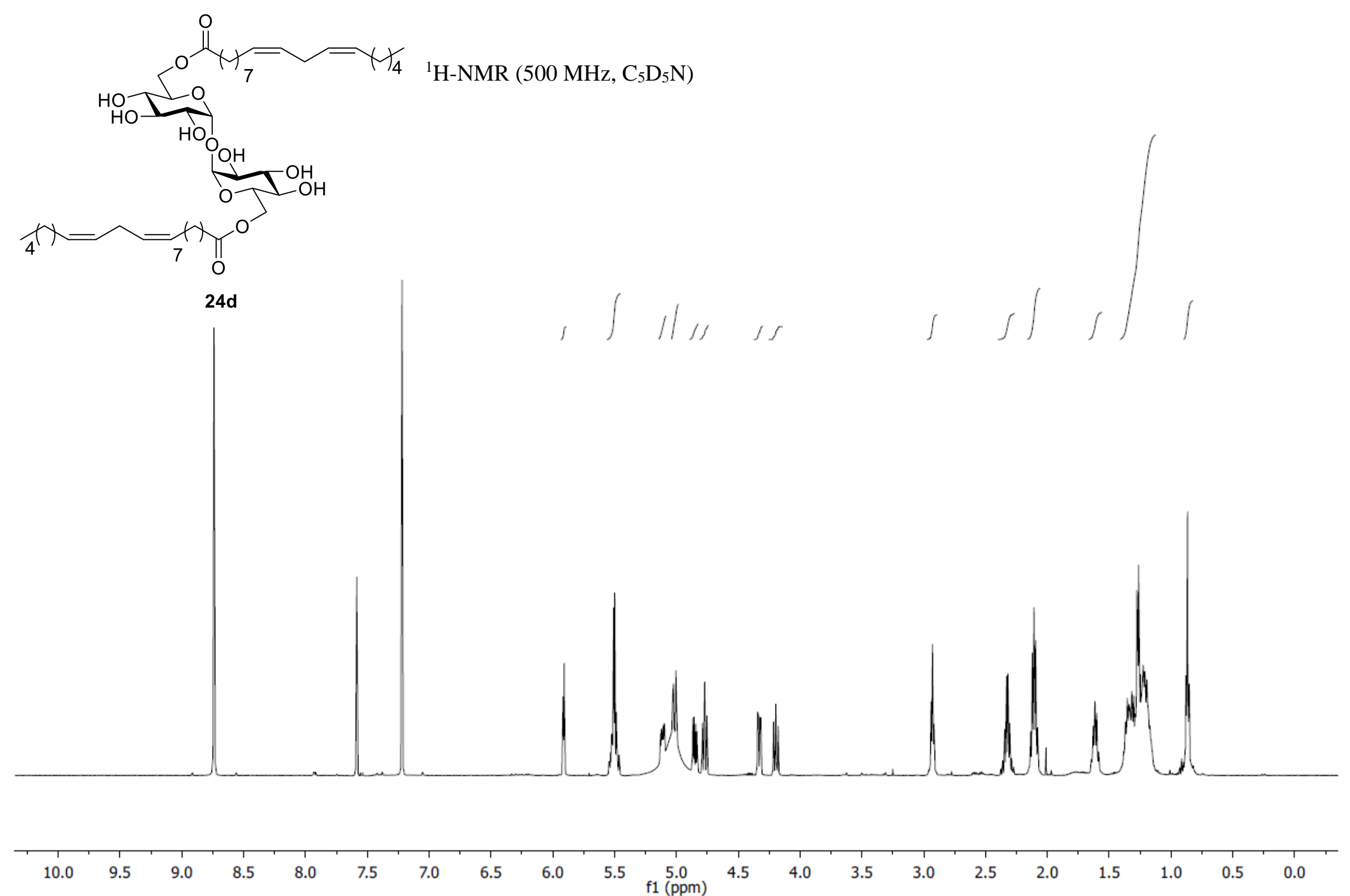


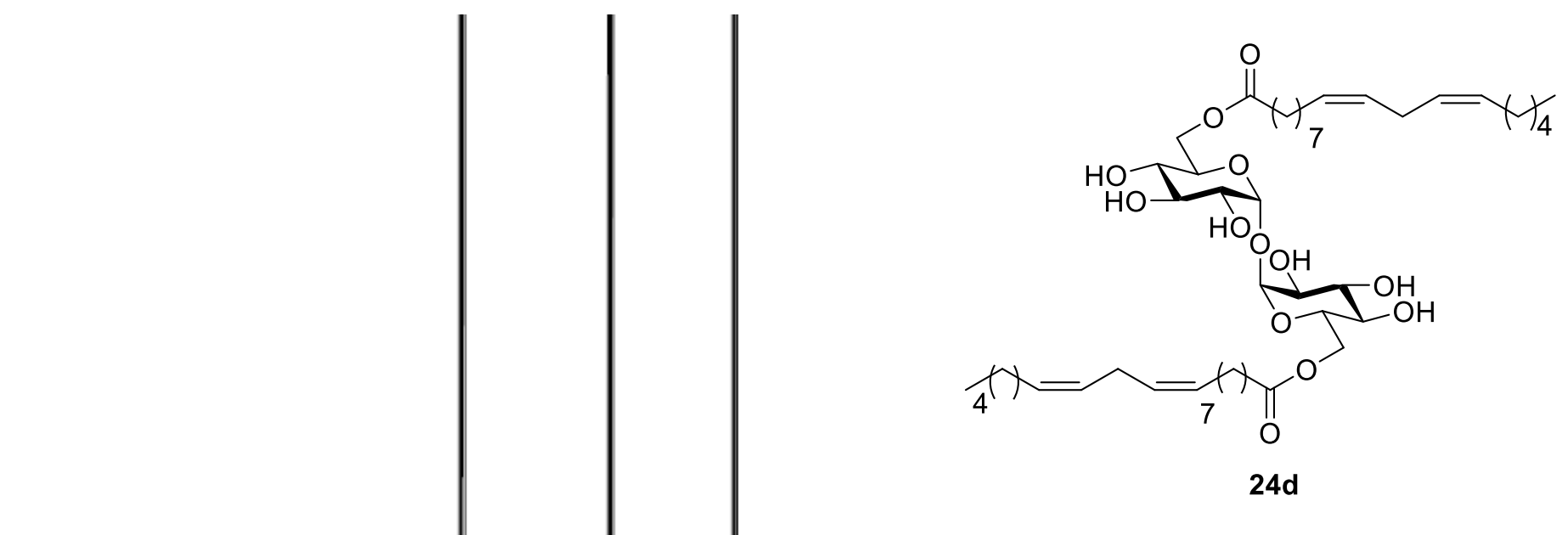

${ }^{13} \mathrm{C}-\mathrm{NMR}\left(125 \mathrm{MHz}, \mathrm{C}_{5} \mathrm{D}_{5} \mathrm{~N}\right)$

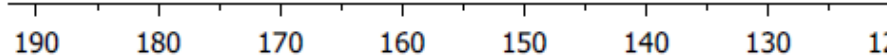

10

$100 \quad 90$

80

70

50

40

30

20

$10 \quad 0$ 


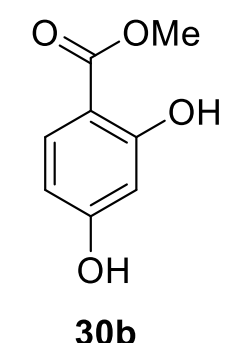

${ }^{1} \mathrm{H}-\mathrm{NMR}\left(500 \mathrm{MHz}, \mathrm{CDCl}_{3}\right)$

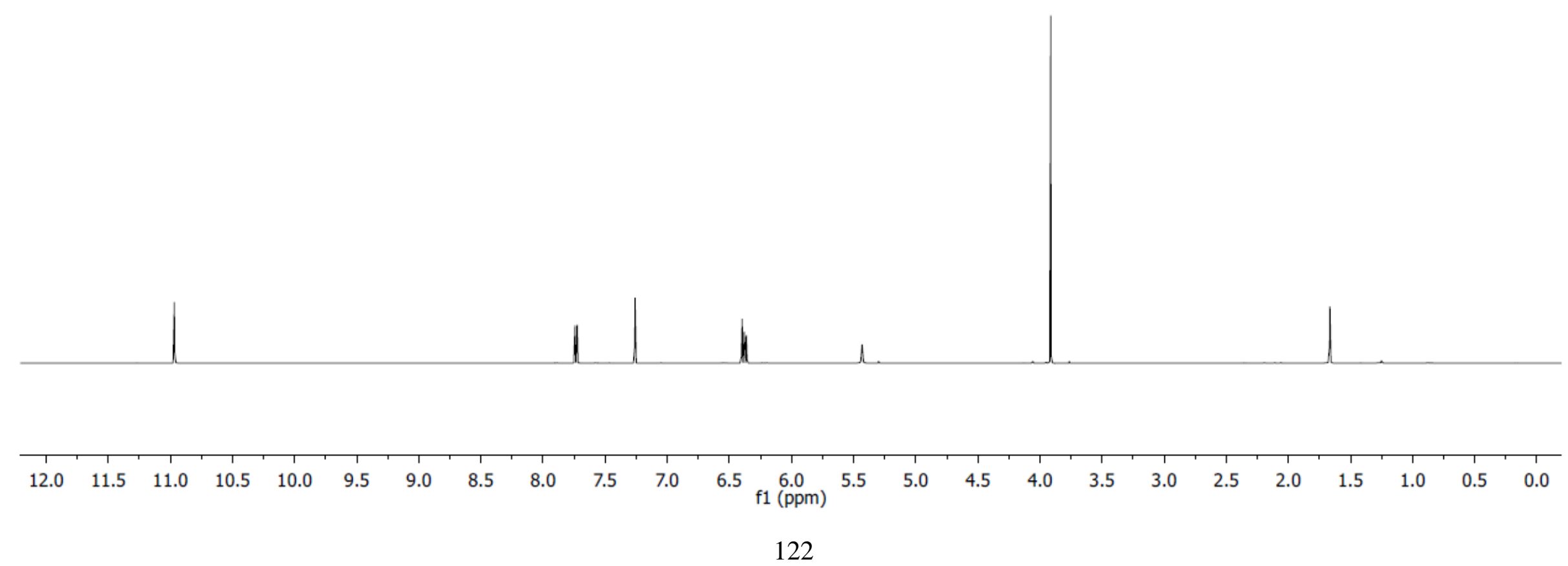




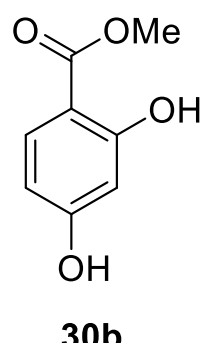

${ }^{13} \mathrm{C}-\mathrm{NMR}\left(125 \mathrm{MHz}, \mathrm{CDCl}_{3}\right)$

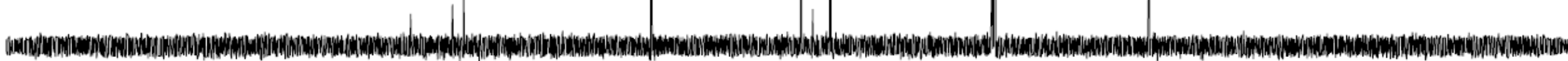

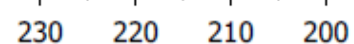




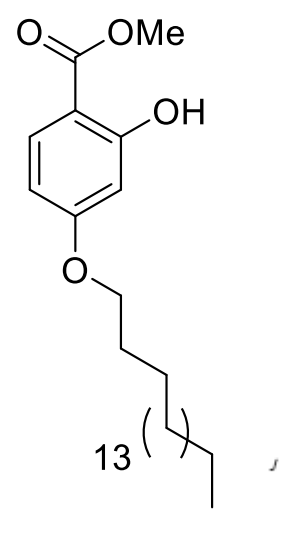

32

${ }^{1} \mathrm{H}-\mathrm{NMR}\left(500 \mathrm{MHz}, \mathrm{CDCl}_{3}\right.$ )
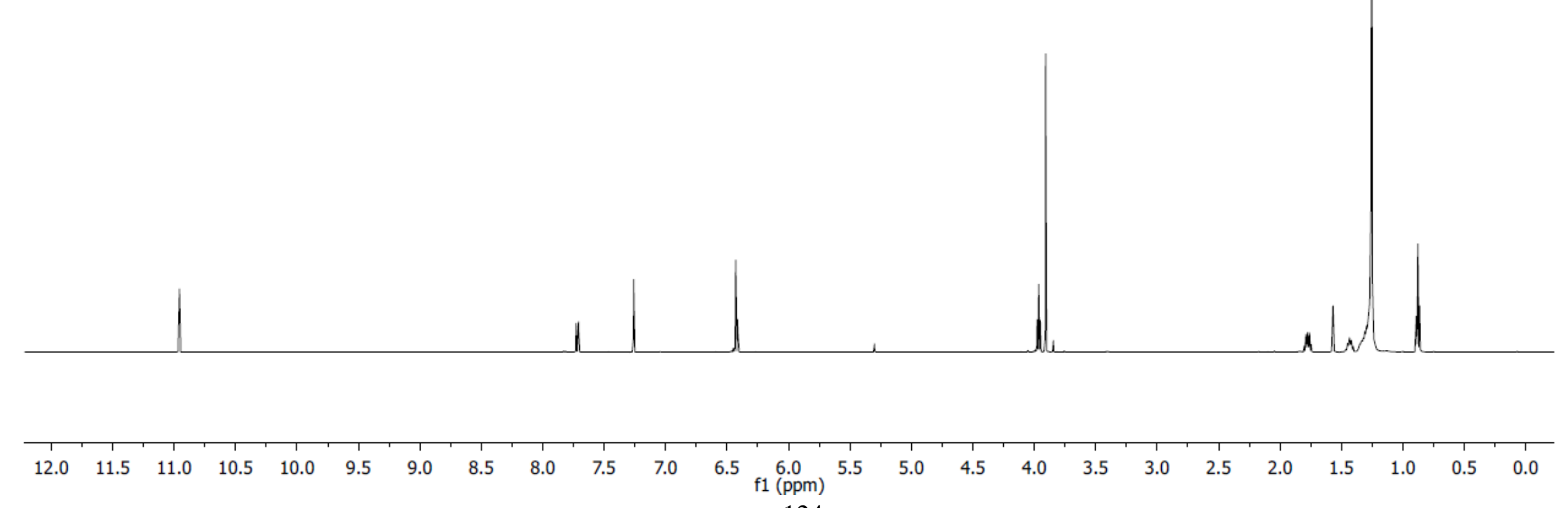


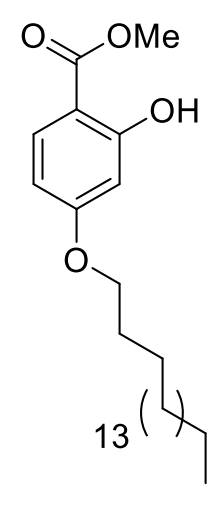

32

${ }^{13} \mathrm{C}-\mathrm{NMR}\left(125 \mathrm{MHz}, \mathrm{CDCl}_{3}\right)$

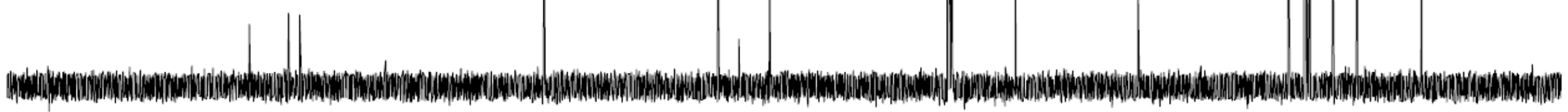

$$
\frac{1}{200}
$$$$
190
$$$$
180
$$$$
170
$$$$
160
$$$$
150
$$
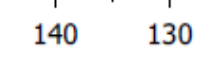

120

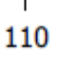

100

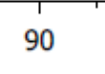

80 

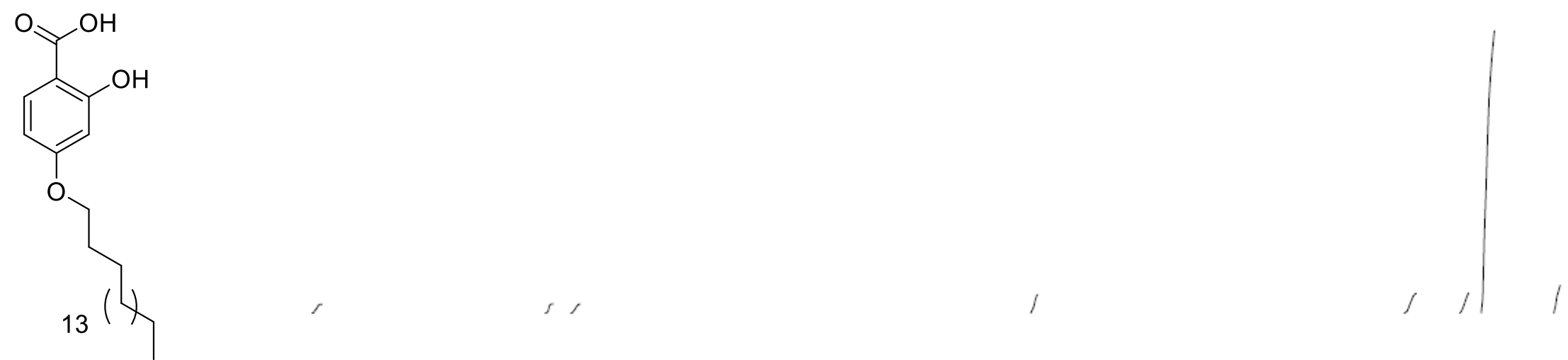

$29 b$

${ }^{1} \mathrm{H}-\mathrm{NMR}\left(500 \mathrm{MHz}, \mathrm{C}_{5} \mathrm{D}_{5} \mathrm{~N}\right)$
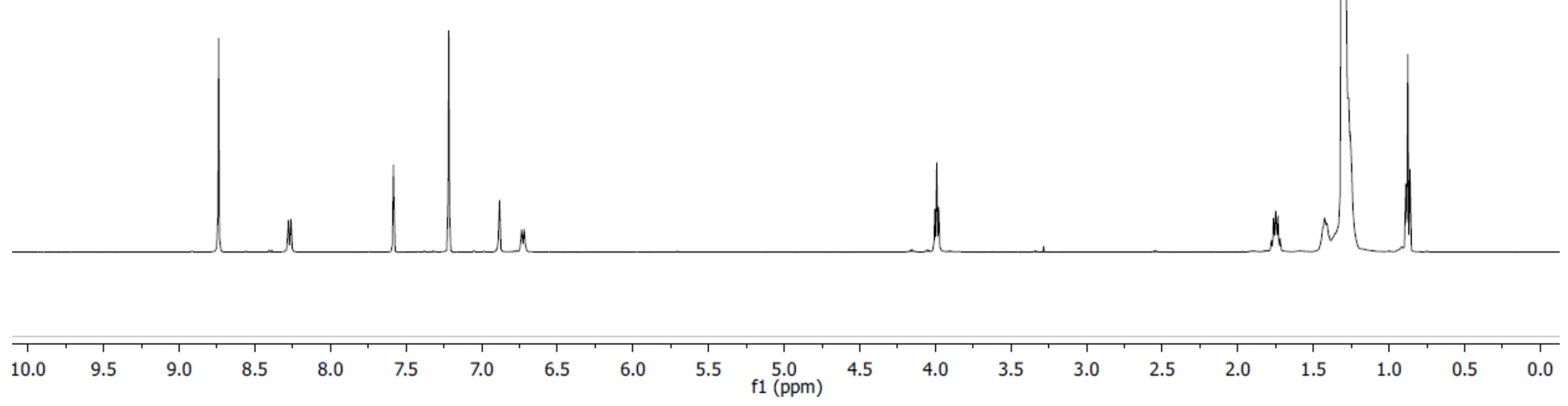

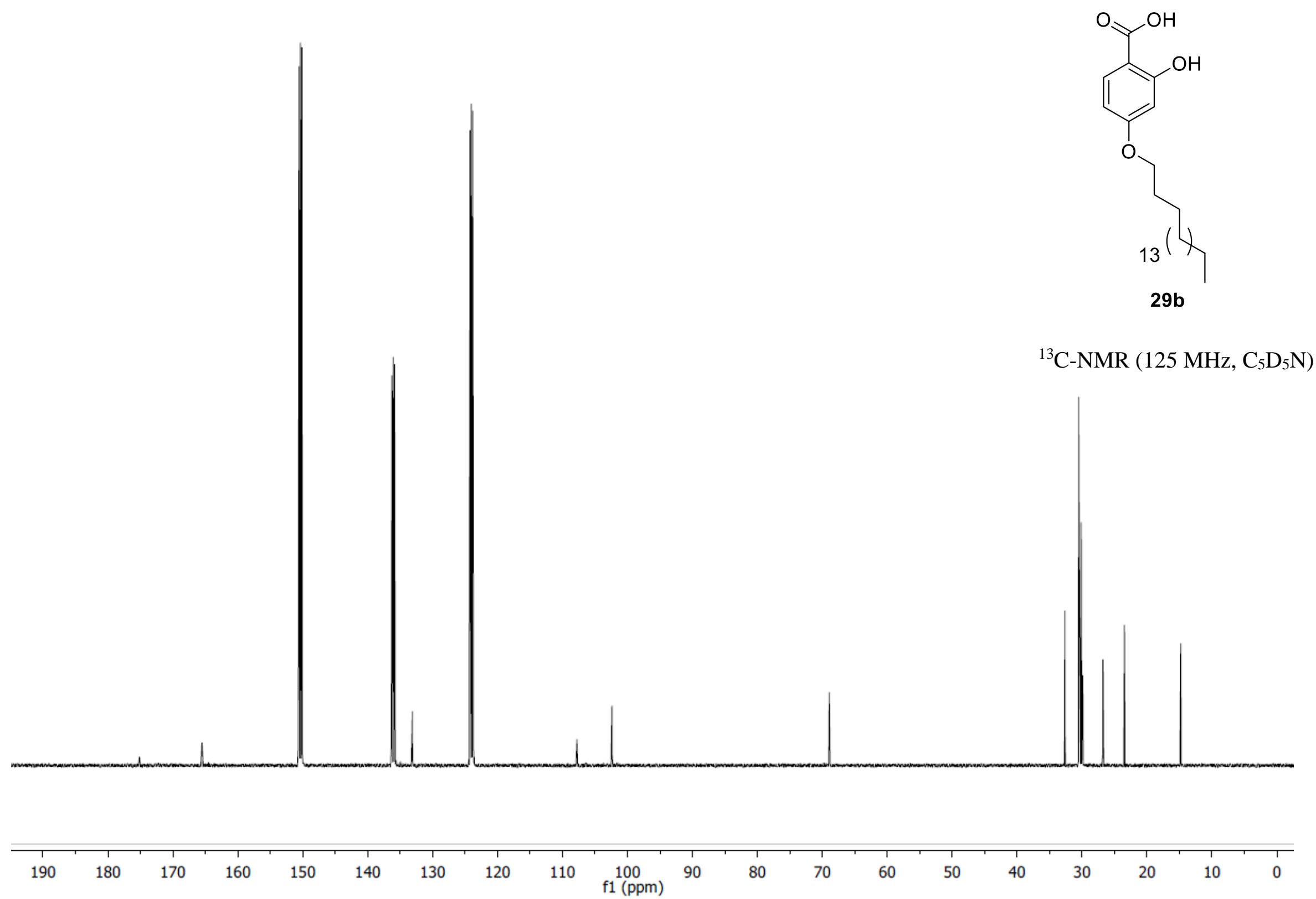


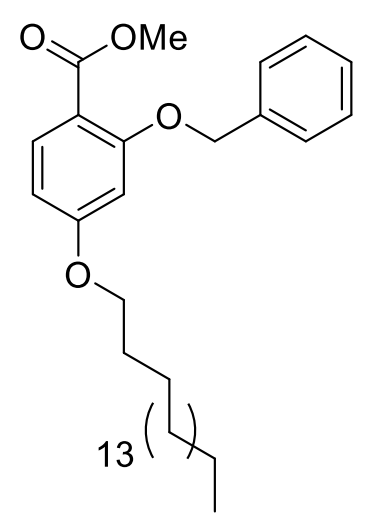

34

${ }^{1} \mathrm{H}-\mathrm{NMR}\left(500 \mathrm{MHz}, \mathrm{CDCl}_{3}\right.$ )

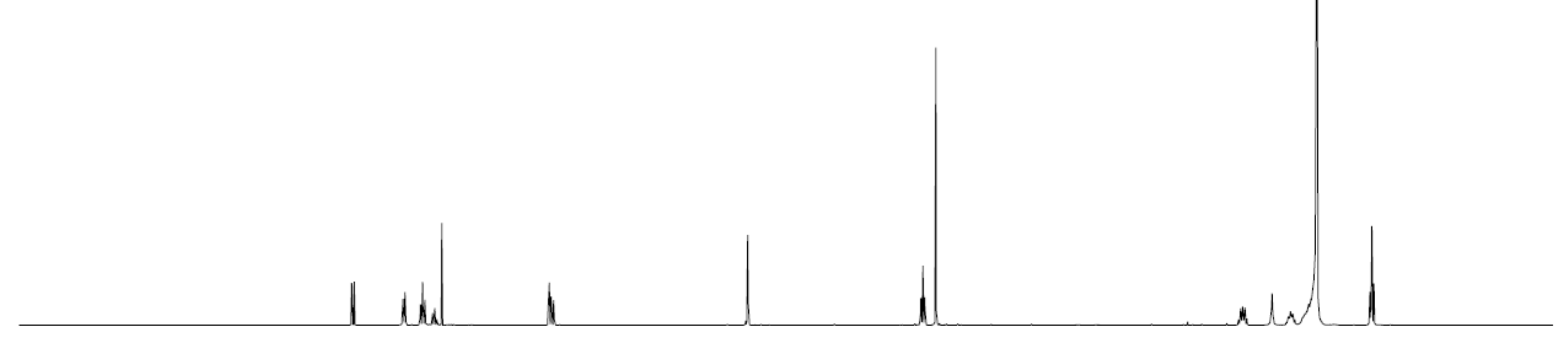




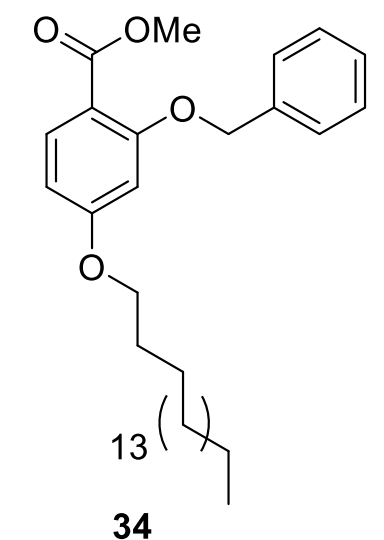

${ }^{13} \mathrm{C}-\mathrm{NMR}\left(125 \mathrm{MHz}, \mathrm{CDCl}_{3}\right)$

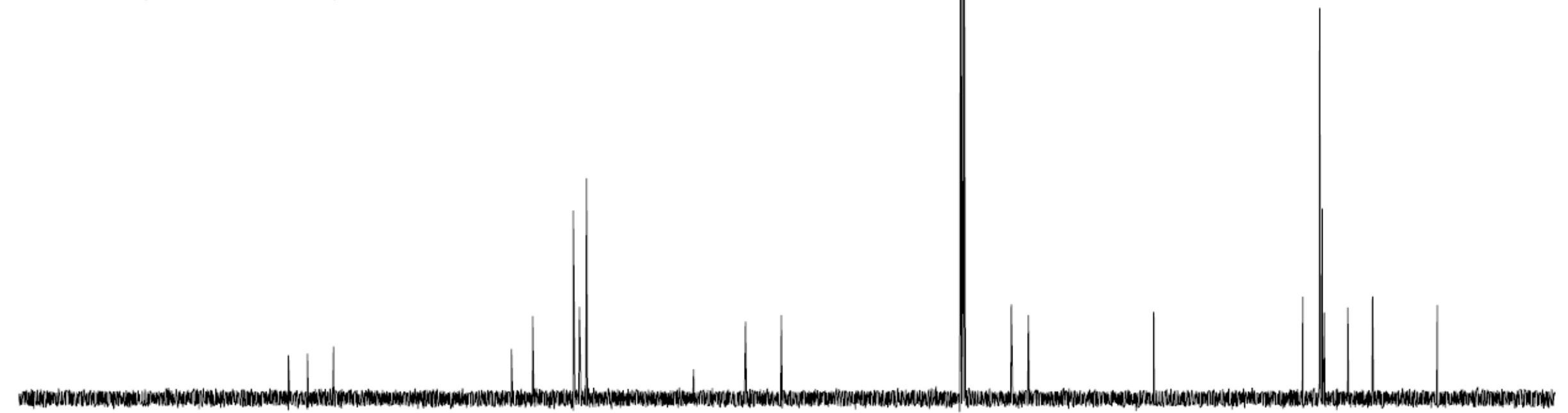

\begin{tabular}{|c|c|c|c|c|c|c|c|c|c|c|c|c|c|c|c|c|c|c|c|}
\hline $\begin{array}{c}1 \\
200\end{array}$ & 190 & 180 & 170 & 160 & $\begin{array}{c}1 \\
150\end{array}$ & 140 & 130 & 120 & $\begin{array}{c}1 \\
110\end{array}$ & $\begin{array}{c}100 \\
\mathrm{f} 1(\mathrm{ppm})\end{array}$ & 90 & 80 & 70 & 60 & 50 & 40 & 30 & 20 & 10 \\
\hline
\end{tabular}




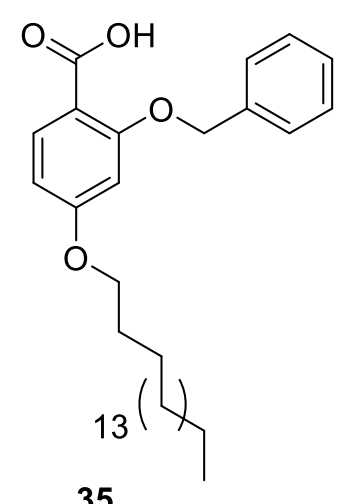

35

${ }^{1} \mathrm{H}-\mathrm{NMR}\left(500 \mathrm{MHz}, \mathrm{C}_{5} \mathrm{D}_{5} \mathrm{~N}\right.$ )
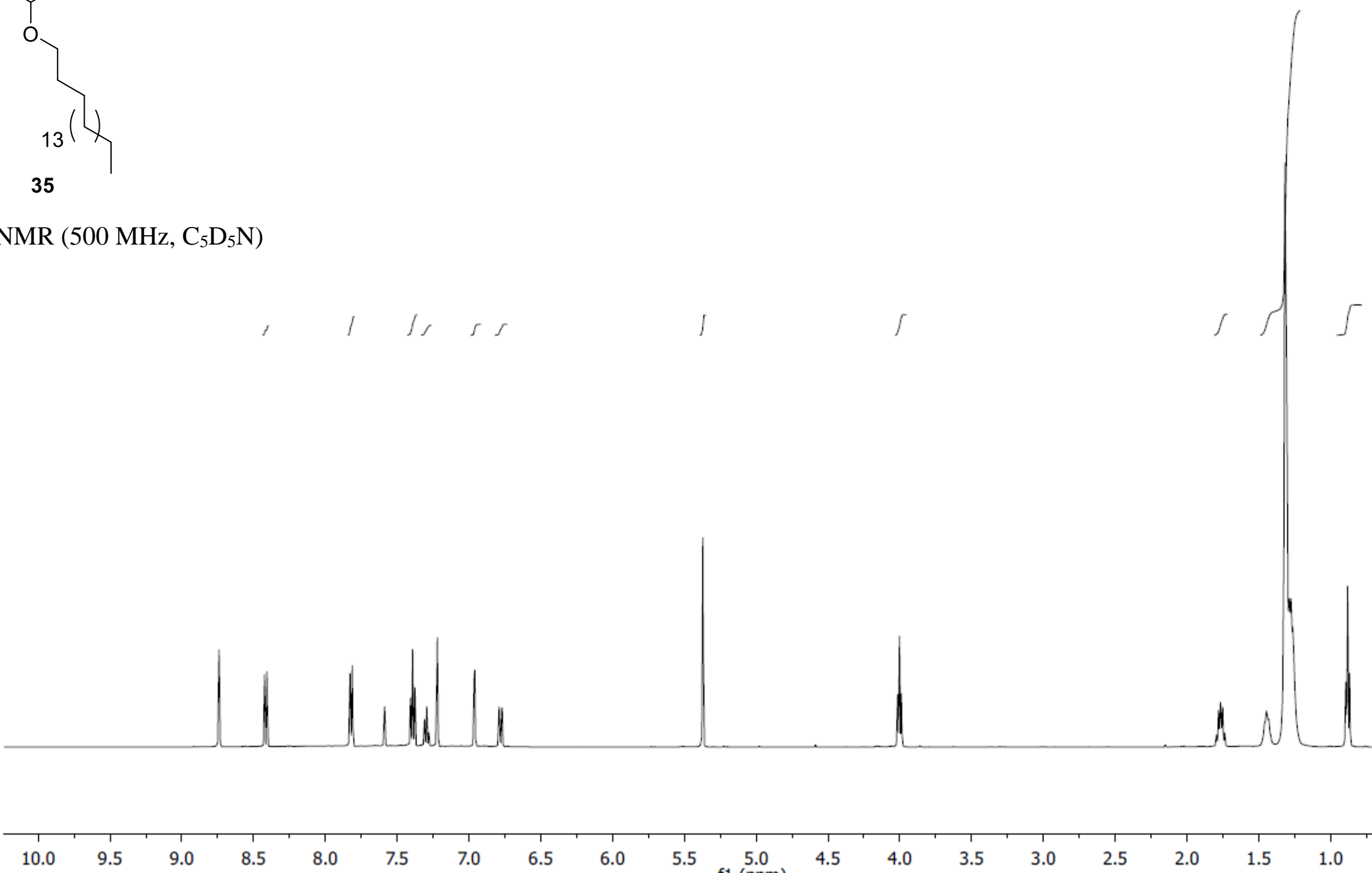


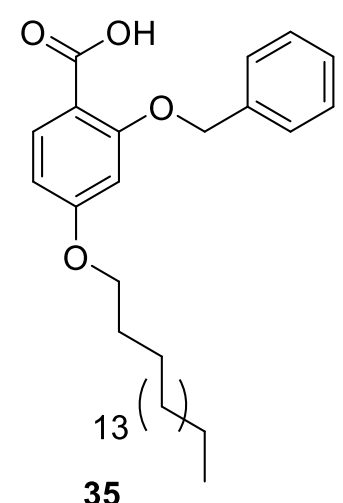

${ }^{13} \mathrm{C}-\mathrm{NMR}\left(125 \mathrm{MHz}, \mathrm{C}_{5} \mathrm{D}_{5} \mathrm{~N}\right)$

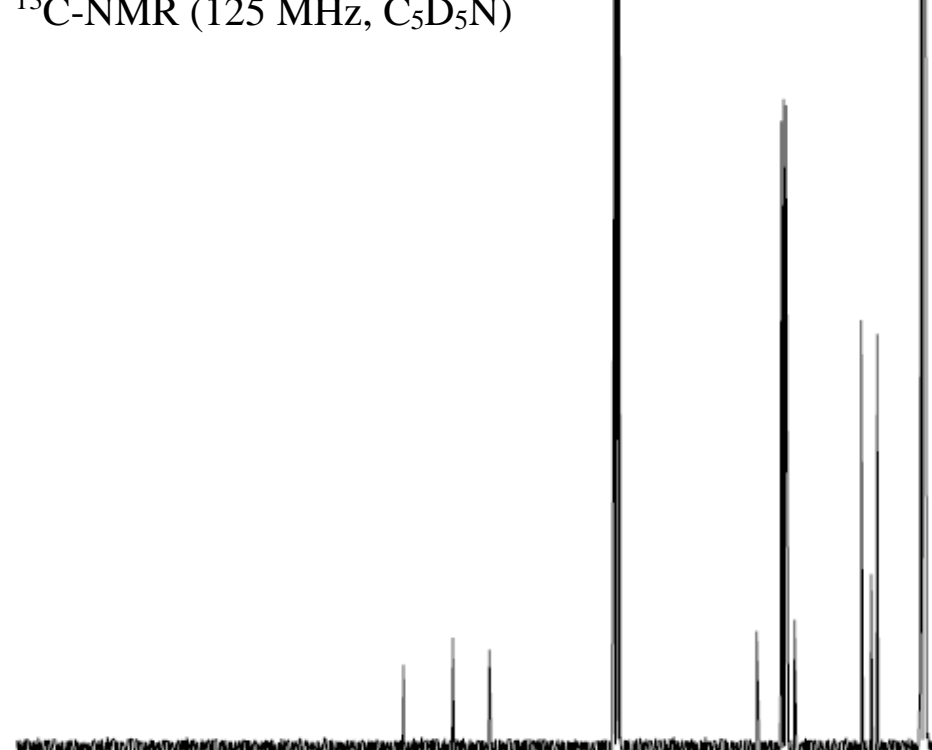

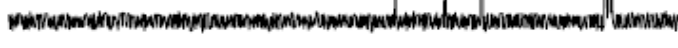

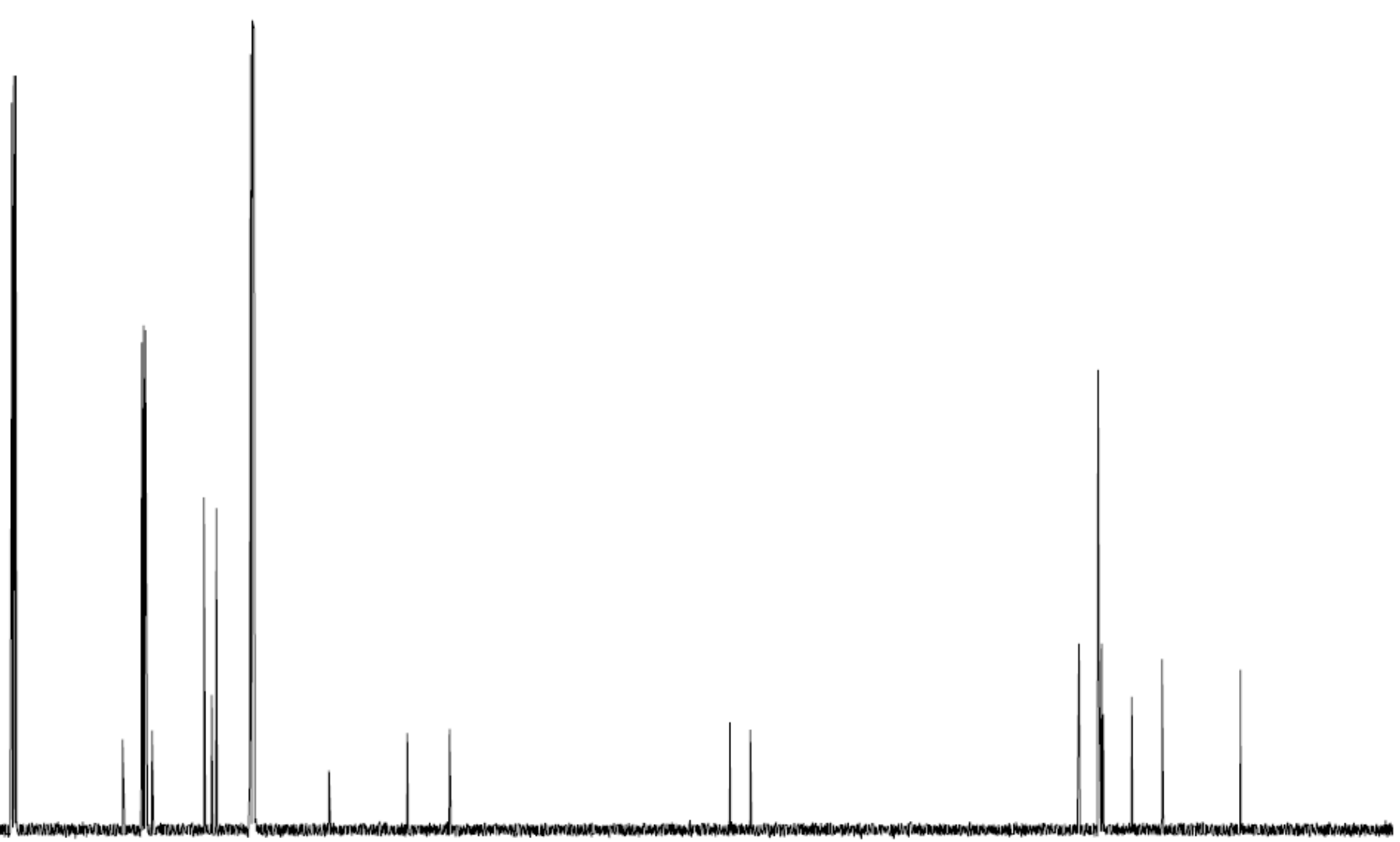

200
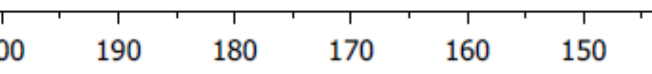

140
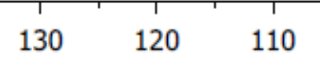

f1 100
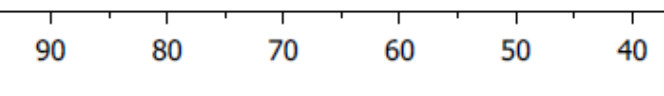


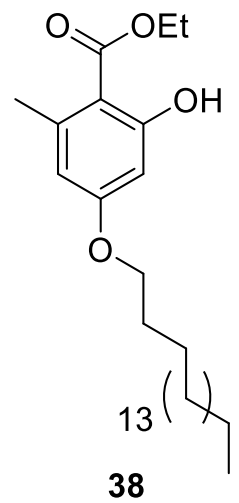

${ }^{1} \mathrm{H}-\mathrm{NMR}\left(500 \mathrm{MHz}, \mathrm{CDCl}_{3}\right)$
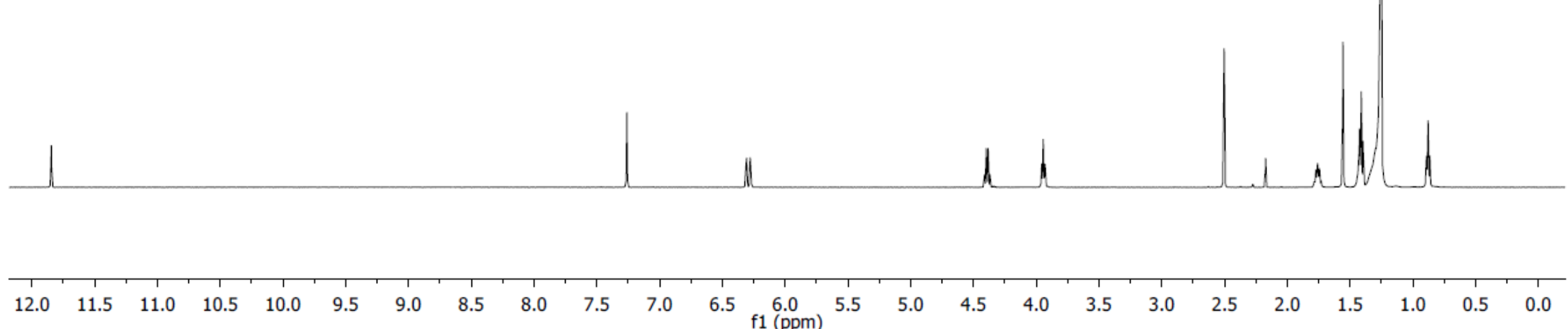


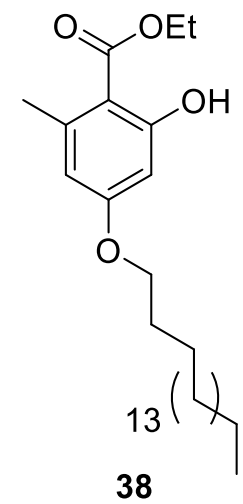

${ }^{13} \mathrm{C}-\mathrm{NMR}\left(150 \mathrm{MHz}, \mathrm{CDCl}_{3}\right)$

190 180 170 160 


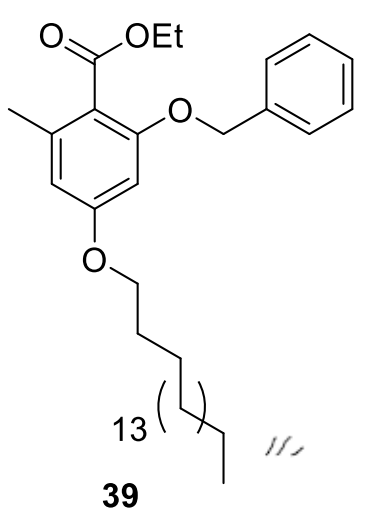

${ }^{1} \mathrm{H}-\mathrm{NMR}\left(500 \mathrm{MHz}, \mathrm{CDCl}_{3}\right.$ )
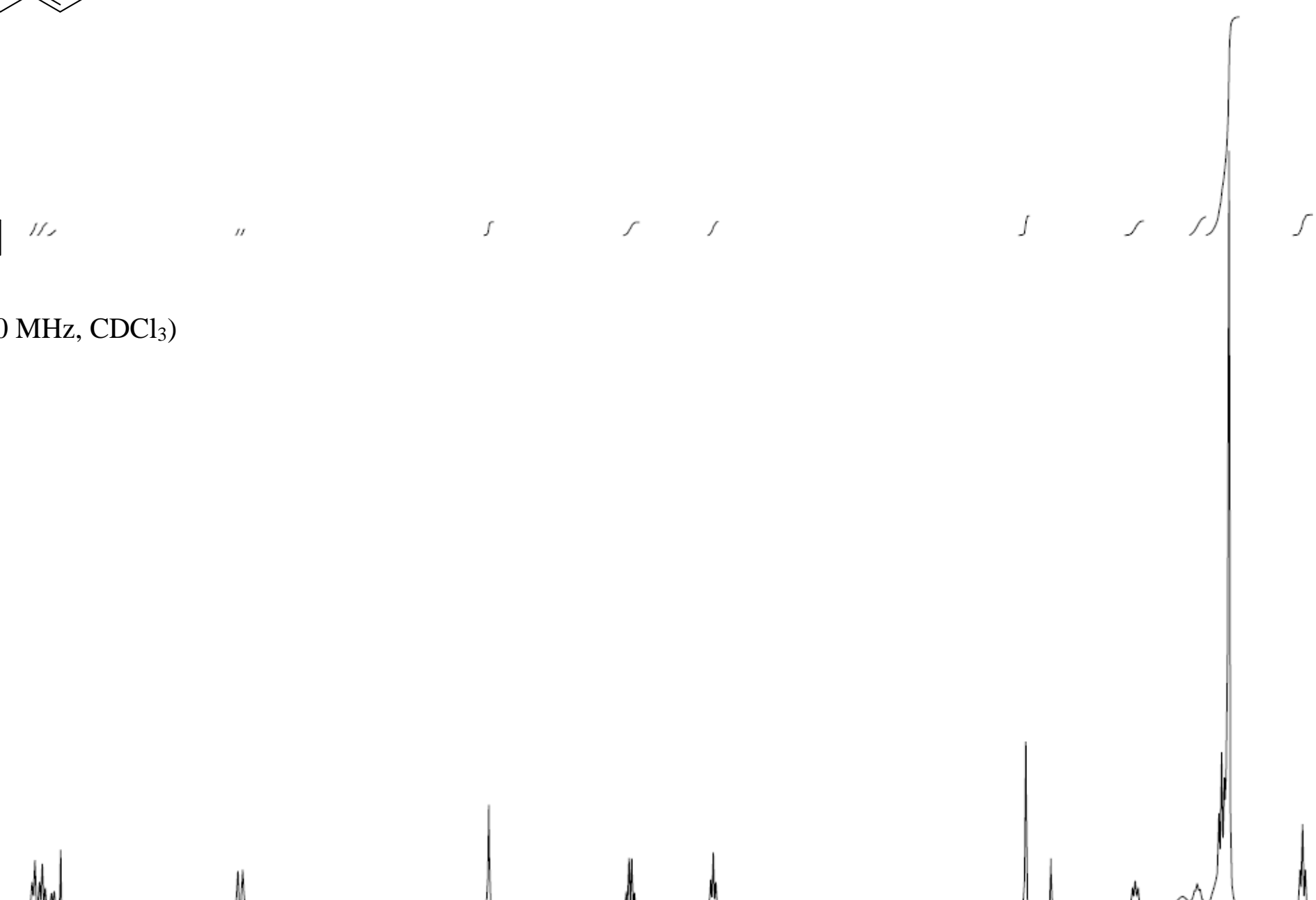

1

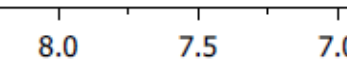




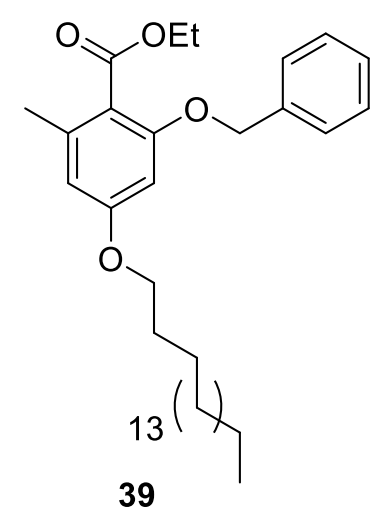

${ }^{13} \mathrm{C}-\mathrm{NMR}\left(150 \mathrm{MHz}, \mathrm{CDCl}_{3}\right.$ )
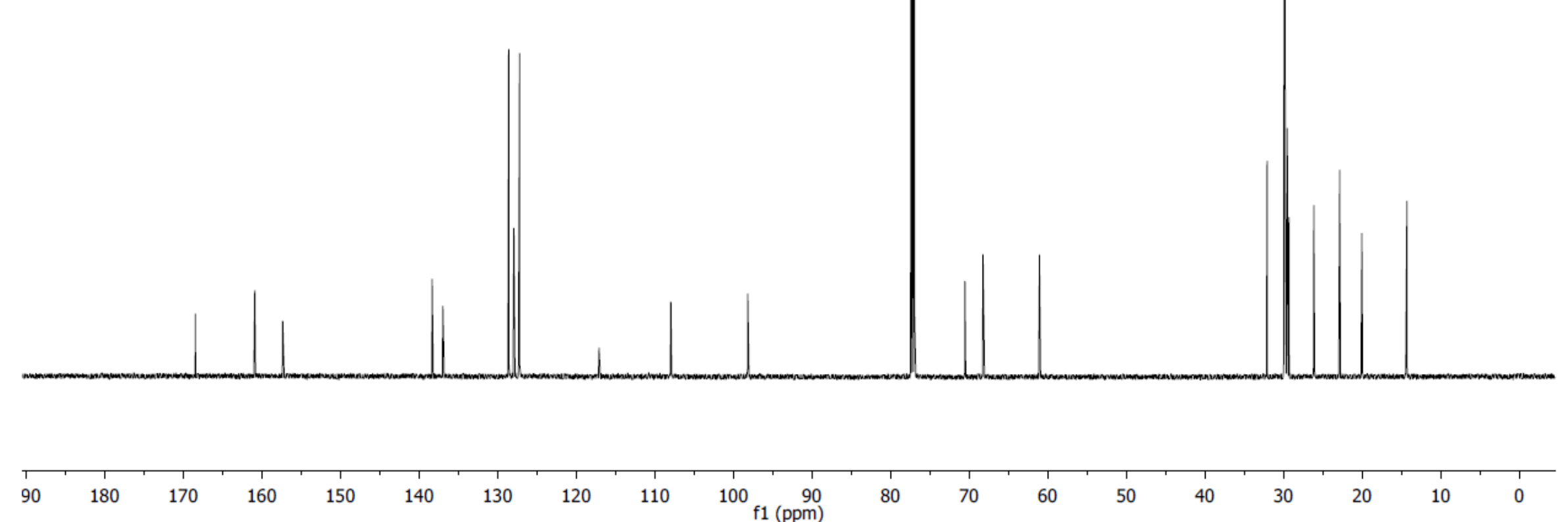

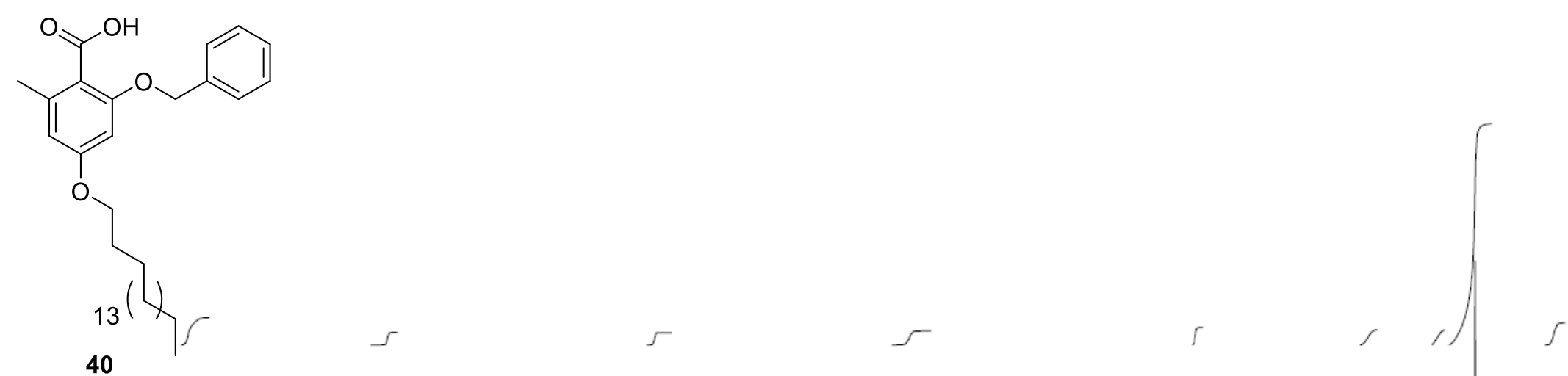

${ }^{1} \mathrm{H}-\mathrm{NMR}\left(500 \mathrm{MHz}, \mathrm{CDCl}_{3}\right.$ )
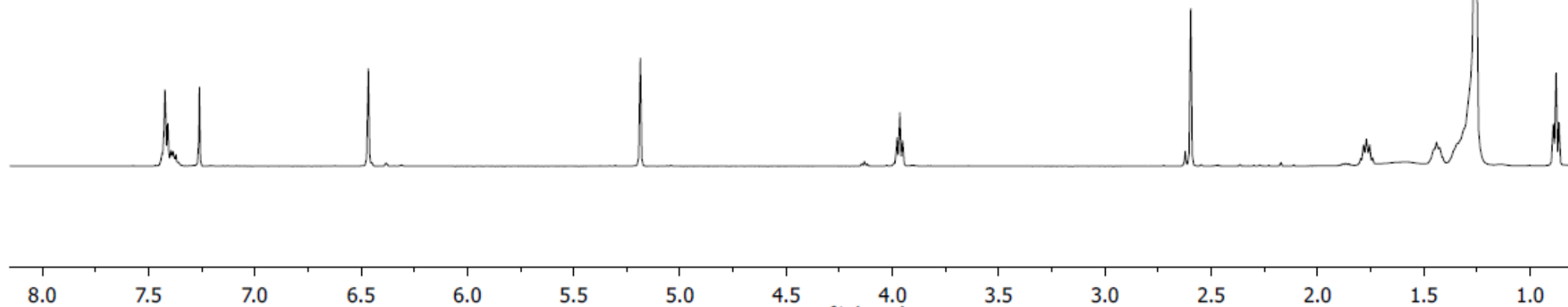


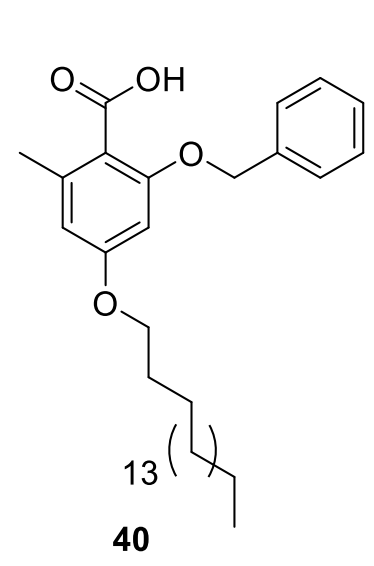

${ }^{13} \mathrm{C}-\mathrm{NMR}\left(150 \mathrm{MHz}, \mathrm{CDCl}_{3}\right)$
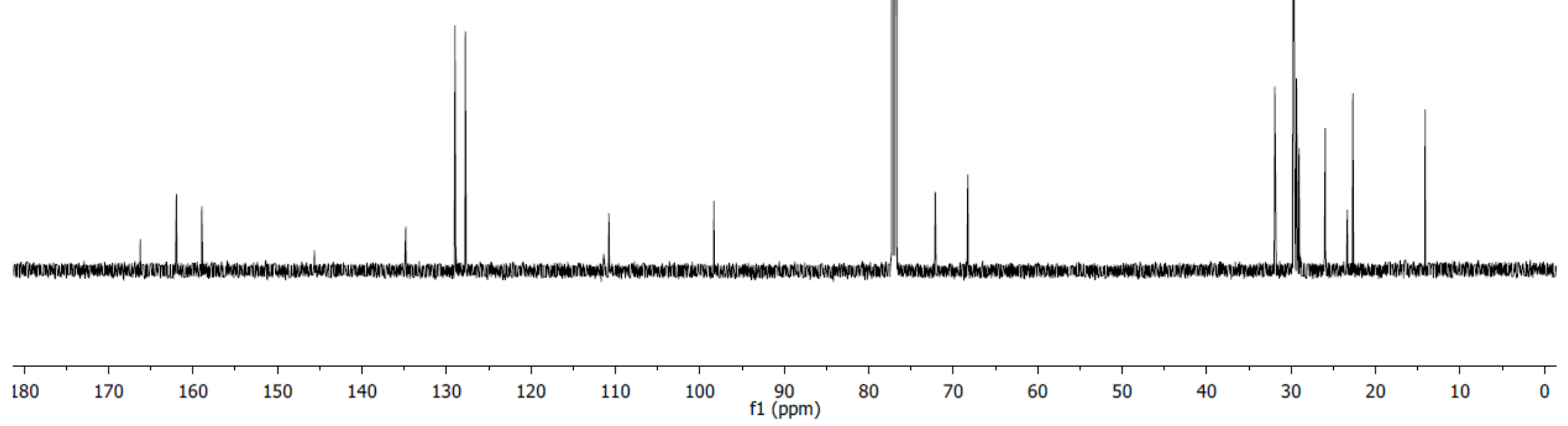

137 


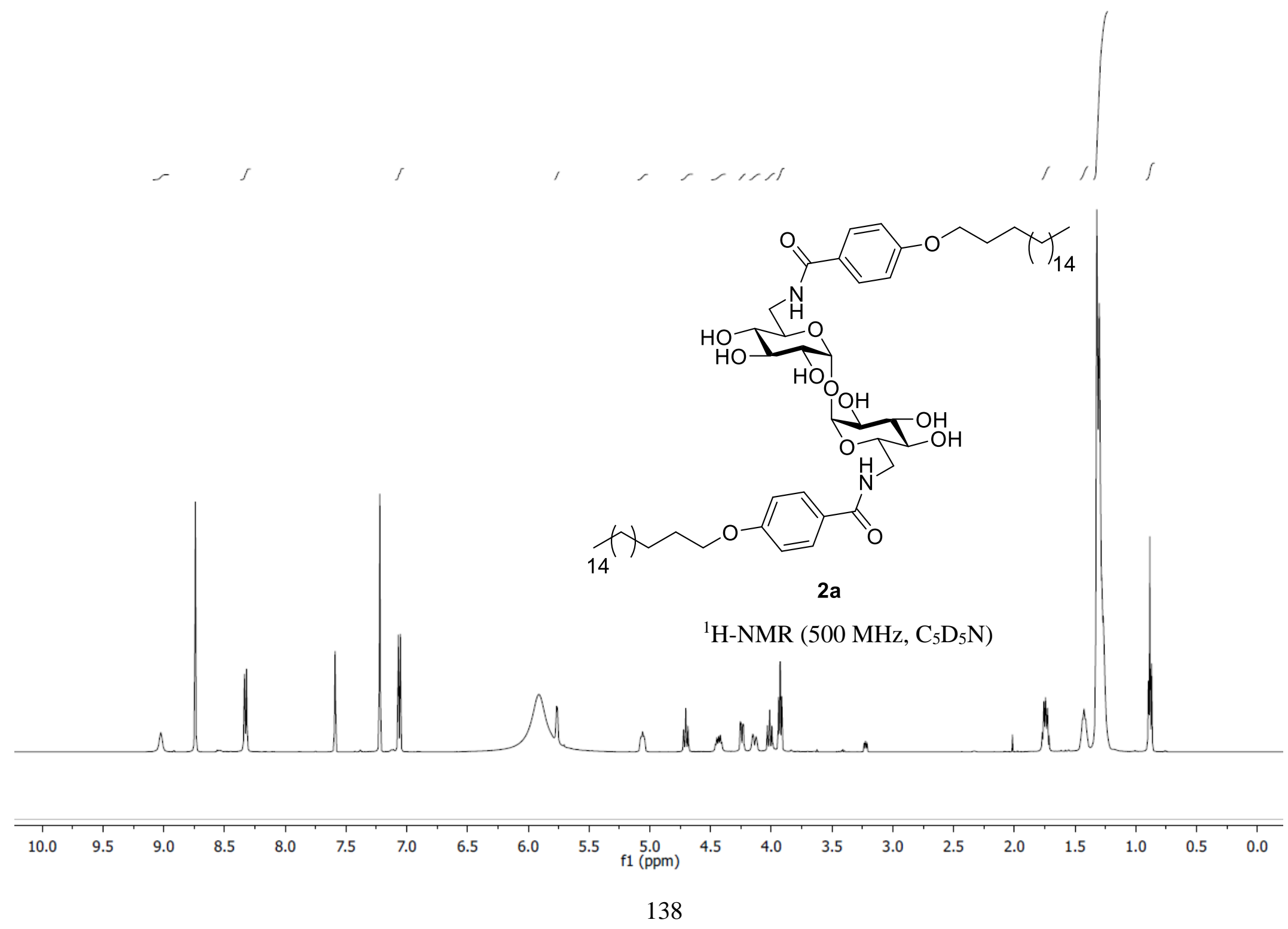




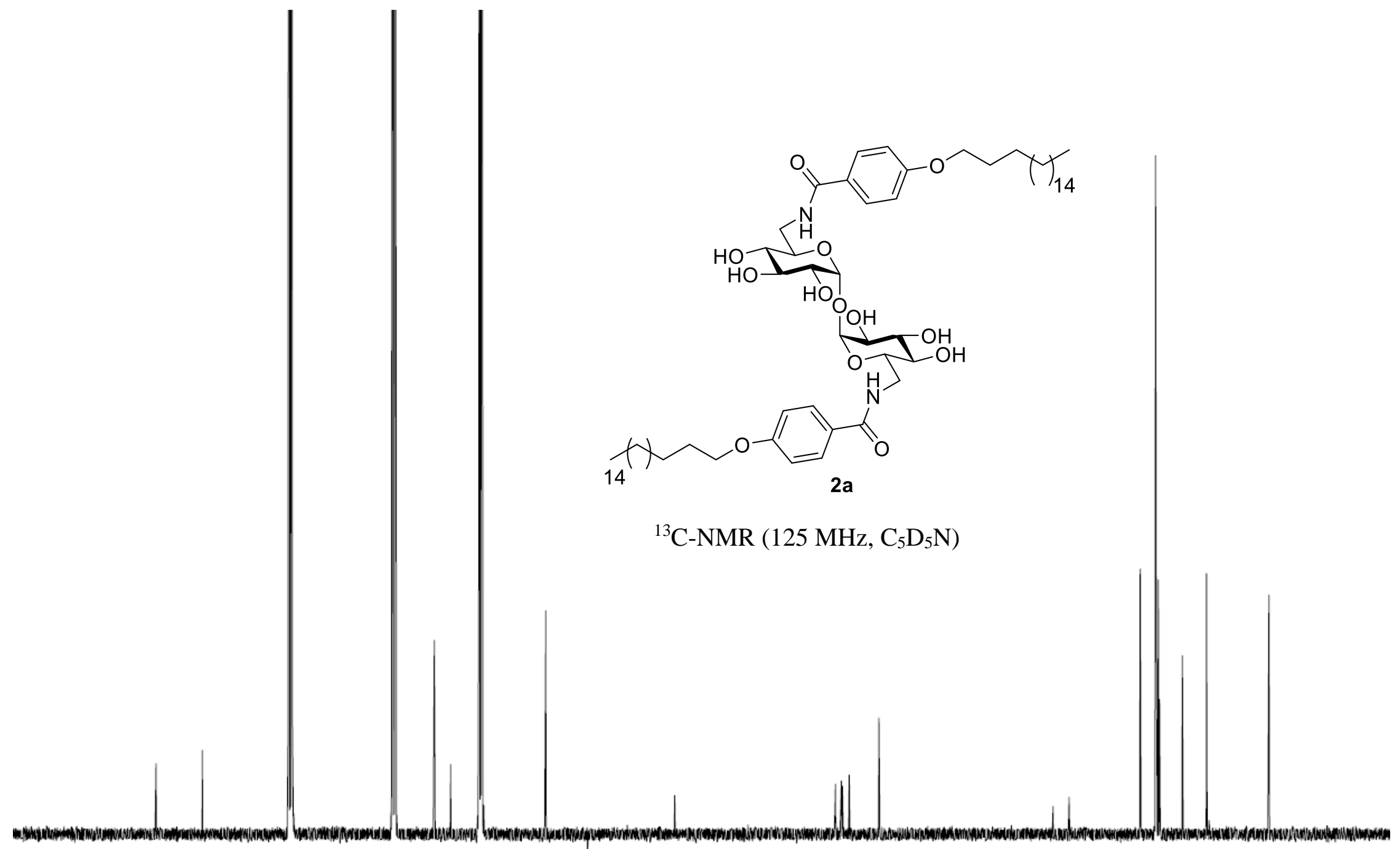

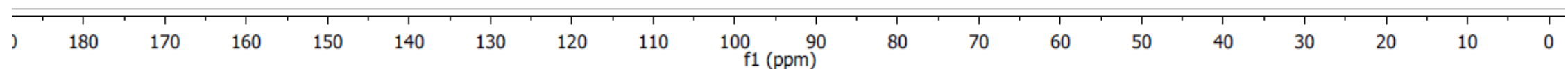




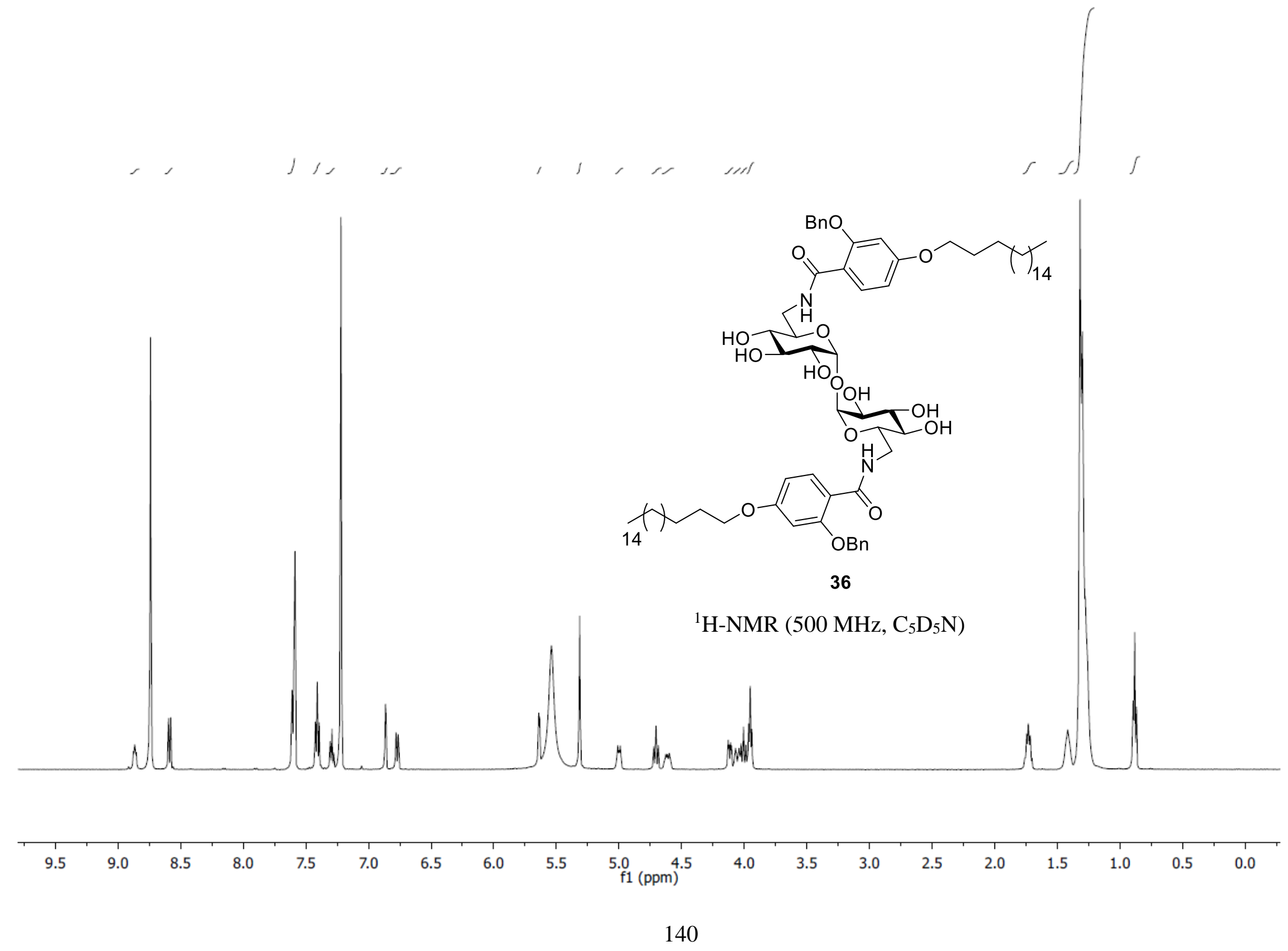




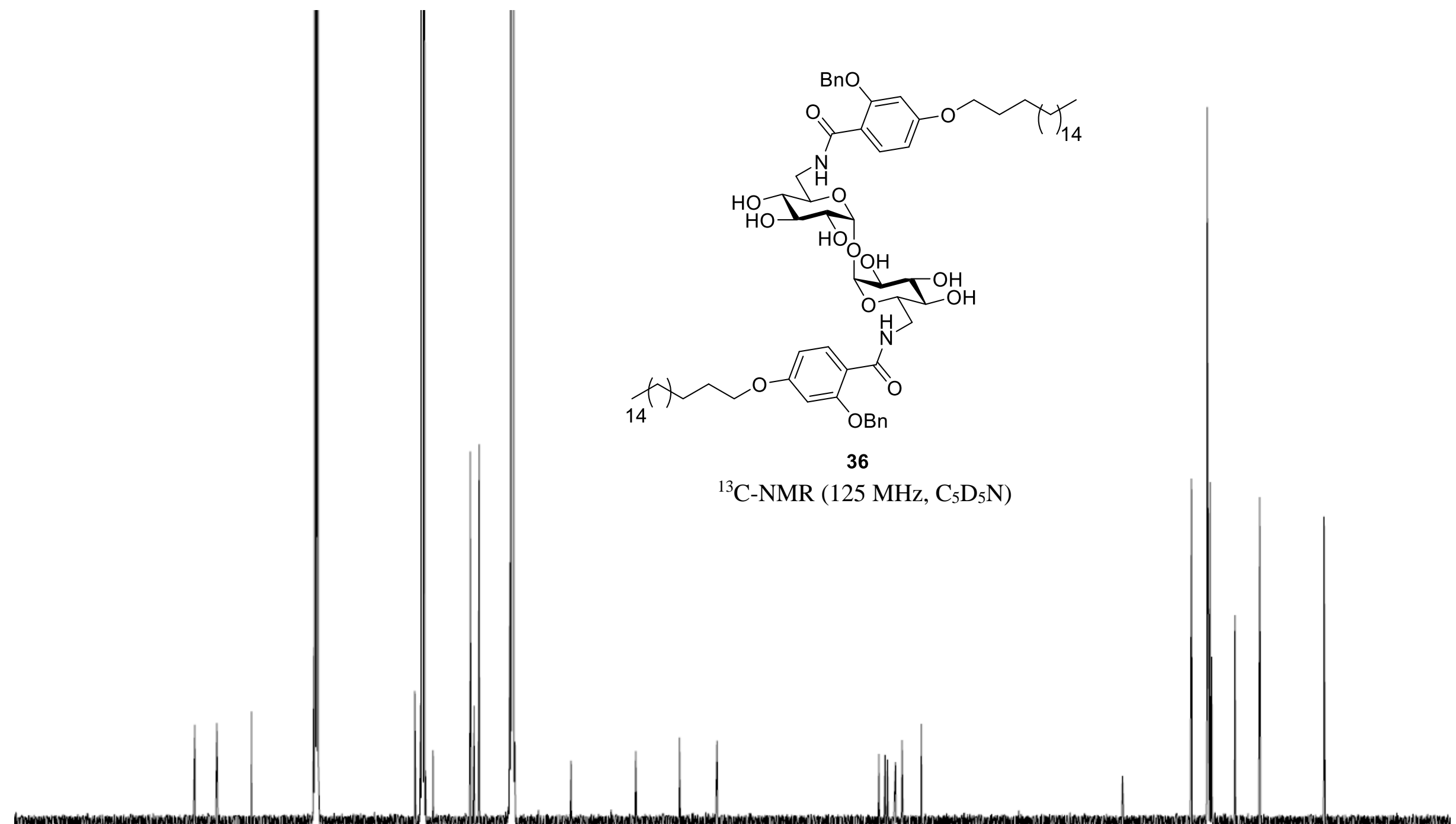

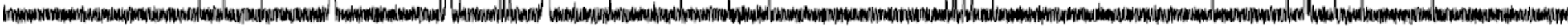

\begin{tabular}{|c|c|c|c|c|c|c|c|c|c|c|c|c|c|c|c|c|c|c|}
\hline$T$ & 1 & 1 & 1 & 1 & 1 & 1 & 1 & 11 & 1 & 1 & 7 & 1 & 1 & 1 & 1 & 1 & 10 & 1 \\
\hline .90 & 180 & 170 & 160 & 150 & 140 & 130 & 120 & 110 & $\begin{array}{c}100 \\
\mathrm{f} 1(\mathrm{ppm})\end{array}$ & 80 & 70 & 60 & 50 & 40 & 30 & 20 & 10 & 0 \\
\hline
\end{tabular}



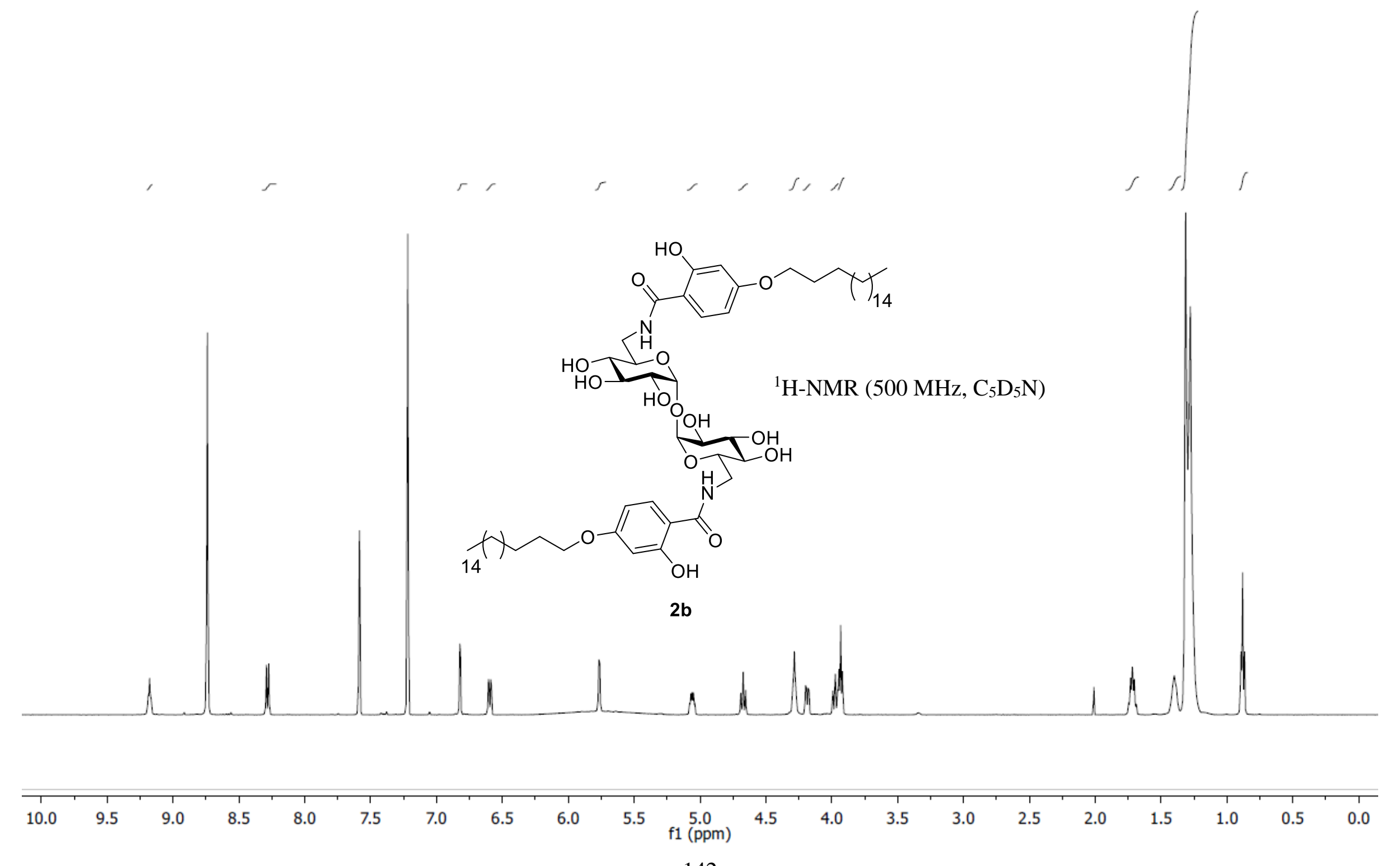


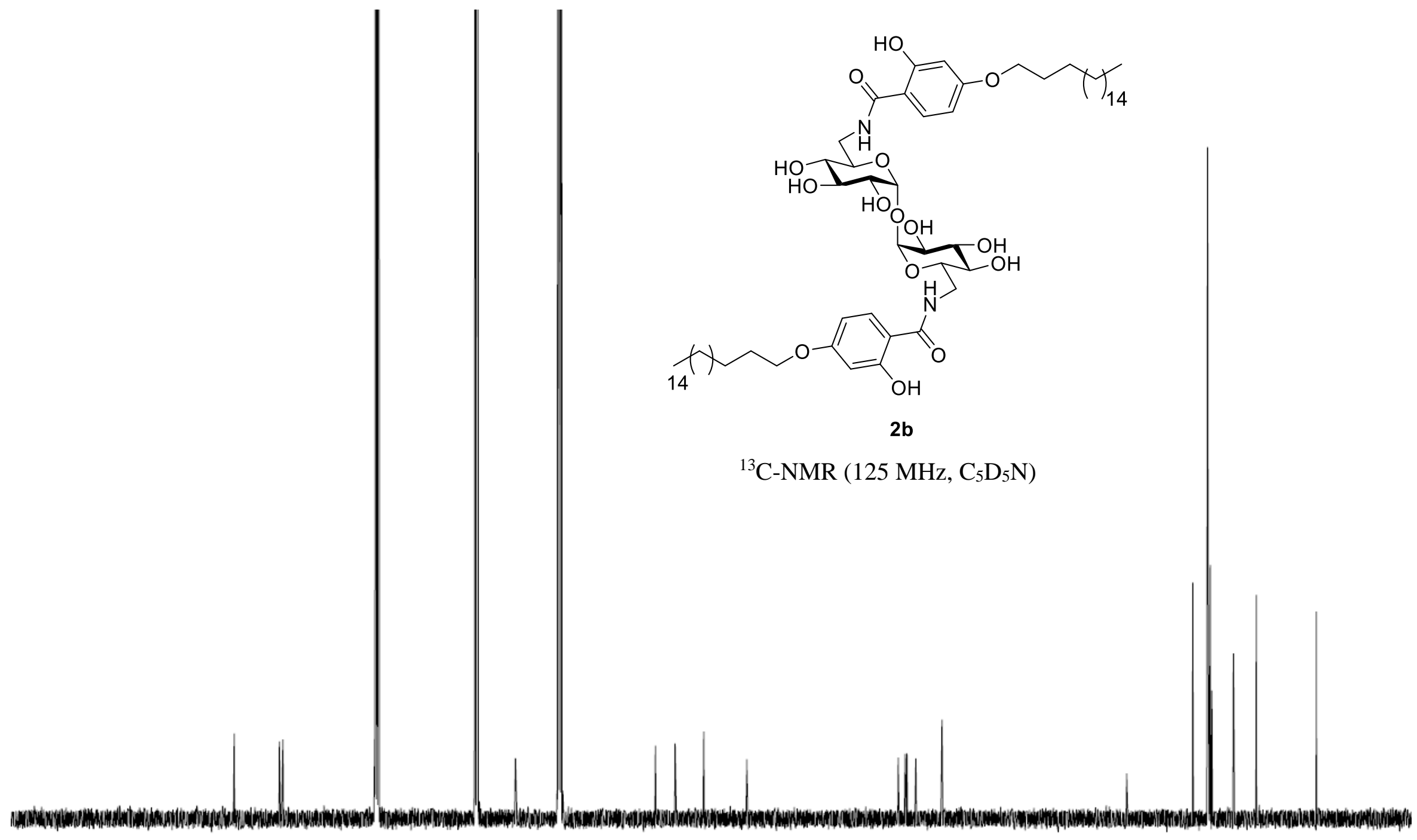

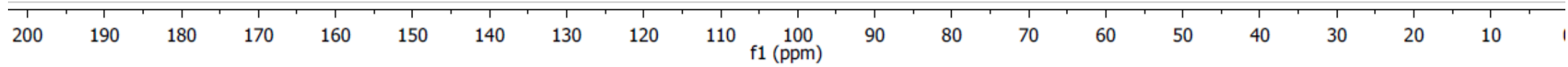



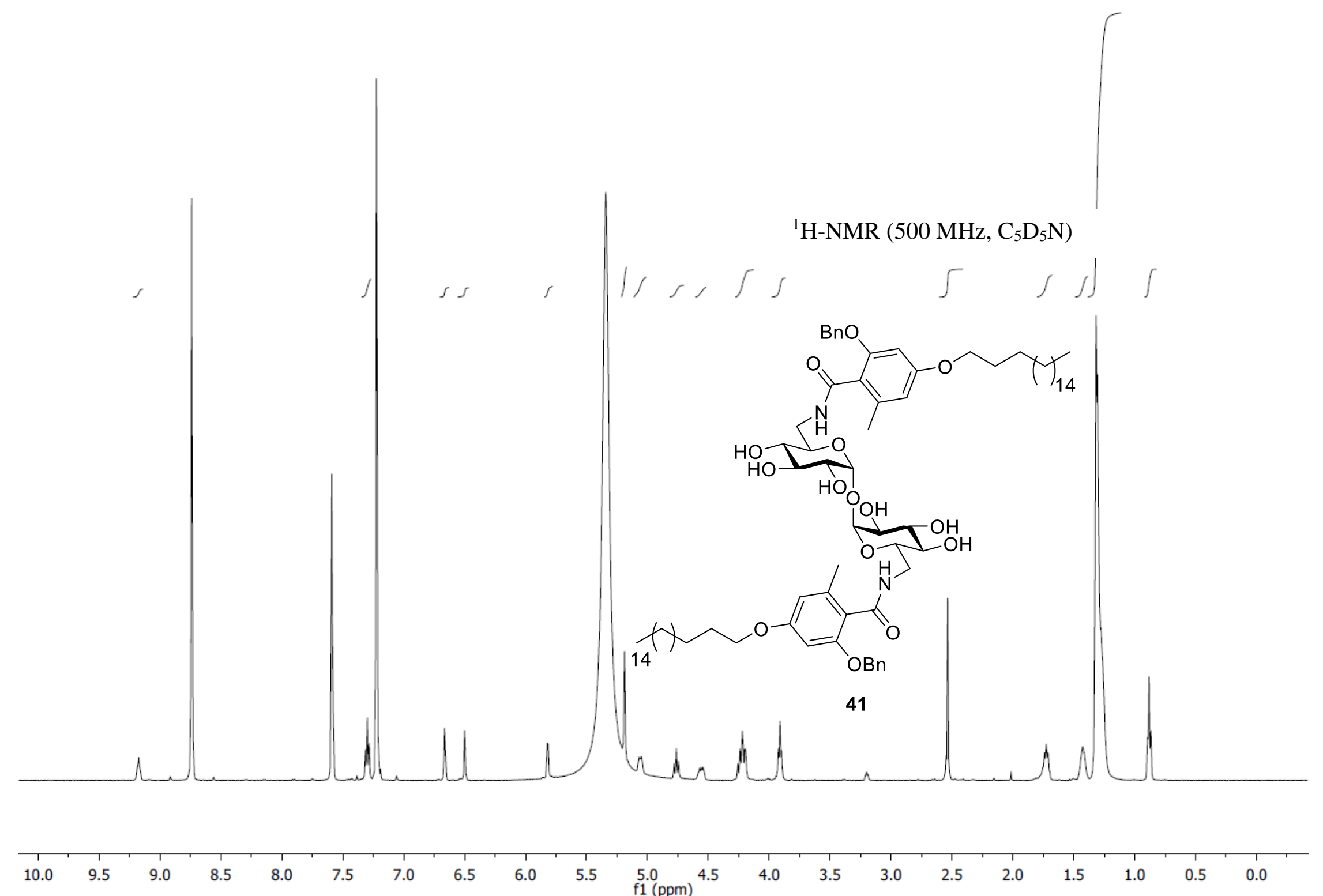


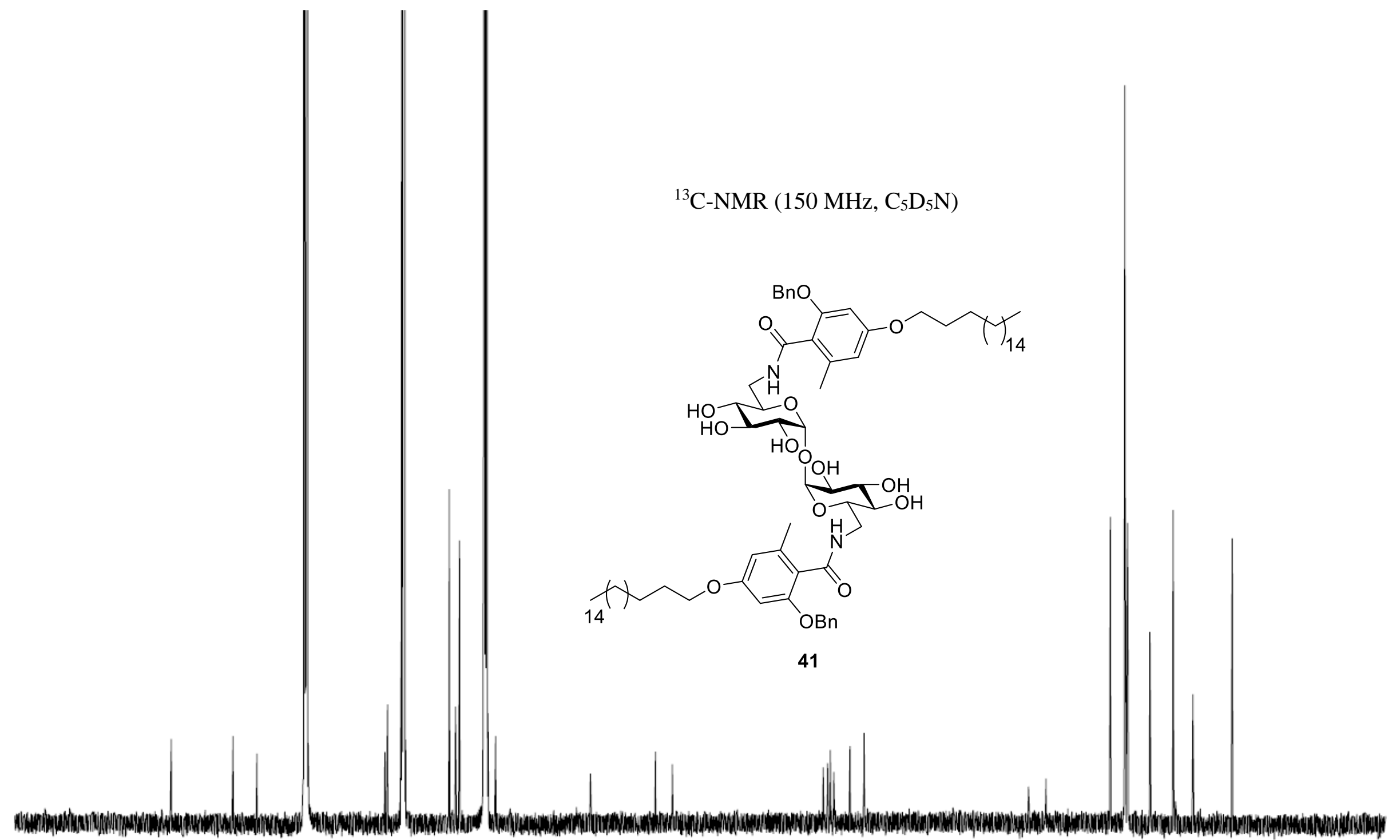

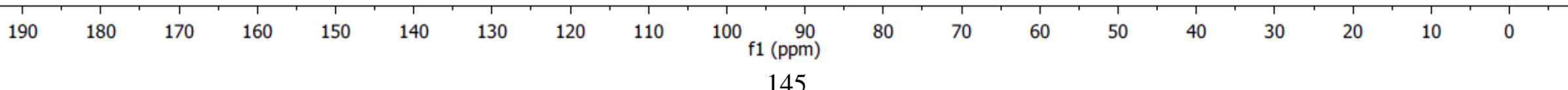



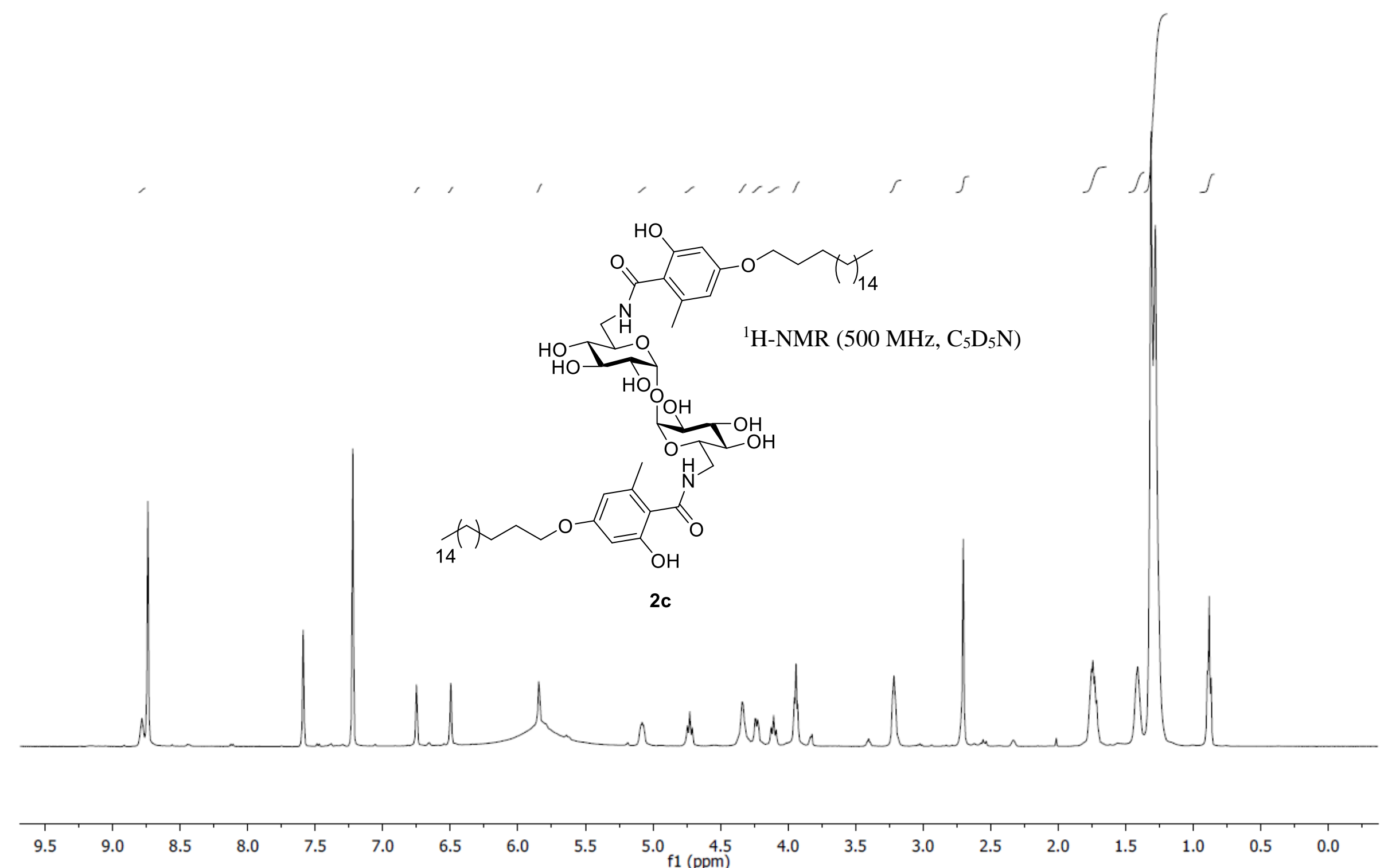

$6.5 \quad 6.0$

$\begin{array}{llr}5.5 & 5.0 & 4.5 \\ & & \end{array}$ 


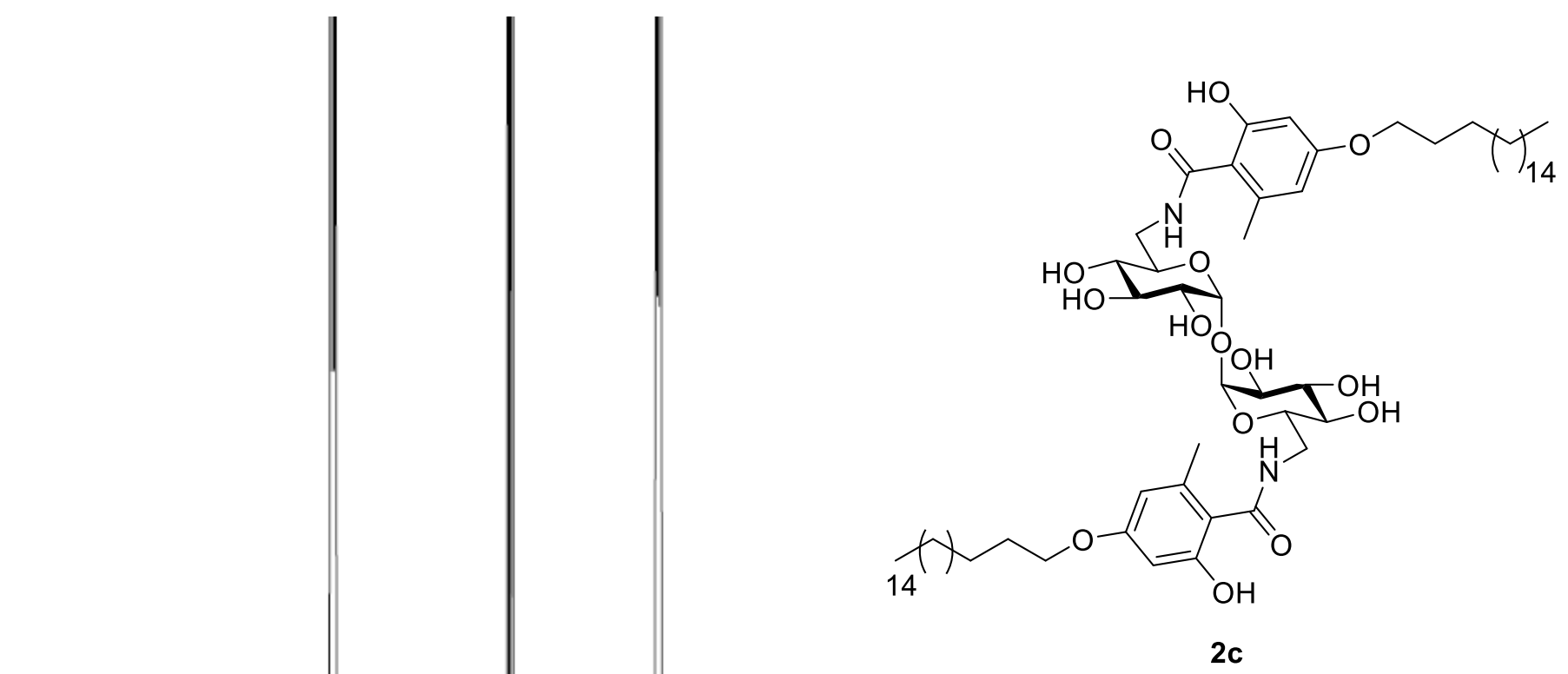

${ }^{13} \mathrm{C}-\mathrm{NMR}\left(150 \mathrm{MHz}, \mathrm{C}_{5} \mathrm{D}_{5} \mathrm{~N}\right)$

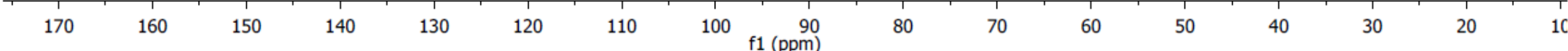

